Szegedi Tudományegyetem

Bölcsészettudományi Kar

DOKTORI DISSZERTÁCIÓ

Bene Zoltánné Pusztai Virág

\title{
Táguló vizuális portfóliók
}

A képfogyasztó meghatározottsága a képi fordulat tükrében

Málnási Bartók György Filozófia Doktori Iskola

Müvészetfilozófia alprogram

Témavezetö:

Dr. habil. Máté Zsuzsanna

föiskolai tanár

Szeged

2018. 


\section{Tartalom}

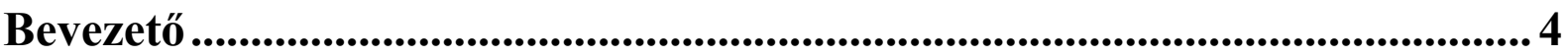

\section{A képekhez való elméleti közelítés nehézségei az alapfogalmak tükrében 8}

I. 1. Úton a képek felé: tapasztalás, látás, befogadás

I.1.1. A tapasztalat filozófiai értelmezési lehetőségeinek alapvető irányai a képkutatás felé vezető úton.

I.1.2. A látás mint filozófiai probléma néhány vonulata …………………………........... 15

I.1.3. A szemlélő pozíciójának megvalósulási formái ........................................................... 21

I.2. Dilemmák a képek ontológiai státuszának és hovatartozásának meghatározása körül..... 29

I.2.1. A képek mibenléte és csoportosításuk nehézségei ....................................................... 30

I.2.2. A képek kultúrájában bekövetkezett változások és fordulópontok ………………...... 36

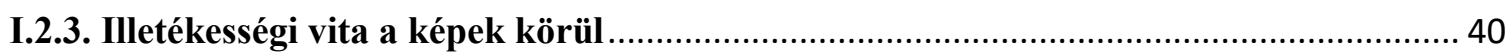

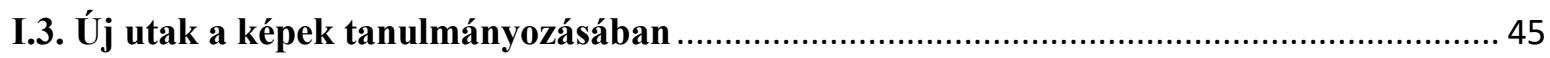

I.3.1. A vizuális kultúra fogalmának értelmezési lehetőségei ............................................ 45

I.3.2. A több diszciplínát igénybe vevő megközelítés létjogosultsága …………………........ 54

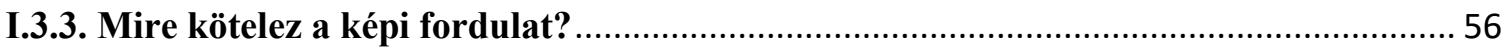

A fejezet összegzése: A képek mint egy vizuális portfólió elemei............................................. 58

II. A képekbe kapaszkodó ember ...................................................................62 62

II.1. A technikai képek általi meghatározottság kialakulásának folyamata .............................62

II.1.1. Változások kép és ember viszonyában.................................................................. 63

II.1.2. Testetlen és befejezetlen technikai képek egy posztfotografikus időszakban ............. 71

II.1.3. A mediatizáció szerepe a képek általi meghatározottság kialakulásában................... 76

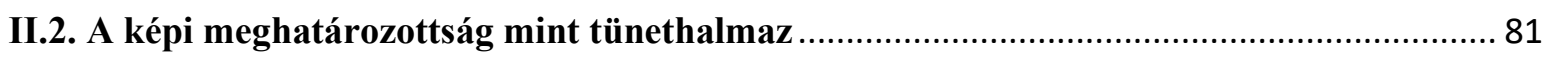

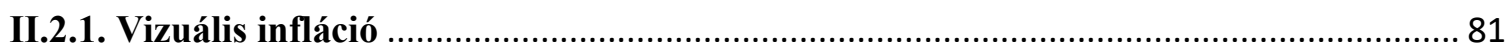

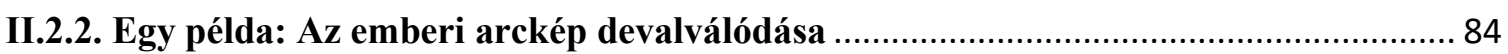

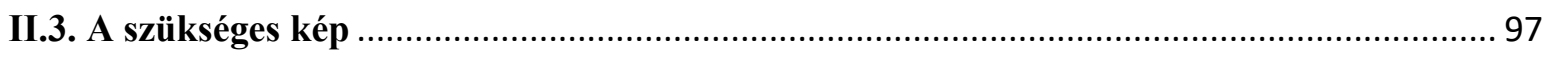

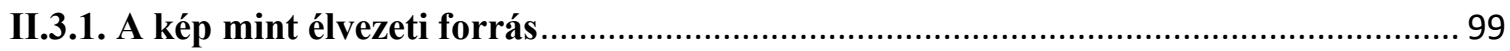

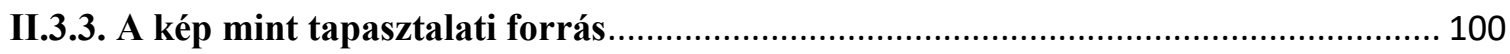

A fejezet összegzése: Az emberi életút mint vizuális portfólió .................................................. 107 
III.1. A vizuális portfólió elemei mint kommunikációs eszközök.............................................. 110

III.1.1. A vizuális portfólió elemeinek ismeretátadásra való alkalmassága ......................... 111

III.1.2. A vizuális portfóliók általi kommunikáció dilemmái .............................................. 120

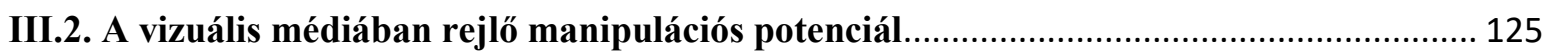

III.2.1. A látvány befogadásának média teremtette új módozatai .................................... 127

III.2.2. A vizuális média és az agresszív energiák relációi ................................................ 131

III.3. Az újmédia közegében realizálódó vizuális portfóliók hatásmechanizmusai................. 139

III.3.1. Képkultúra az újmédia felületein ........................................................................... 139

III.3.2. A szabadság lehetőségei a képekhez kötöttség korában ......................................... 140

A fejezet összegzése: Irányított tekintet, manipulált figyelem .............................................. 145

IV. A képekből összerakott ember......................................................................148

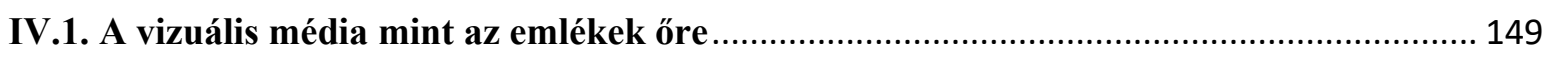

IV.1.1. A technikai memória előtérbe kerülése................................................................... 149

IV.1.2. A technikai képek szerepe az emlékezet narratívájában........................................... 152

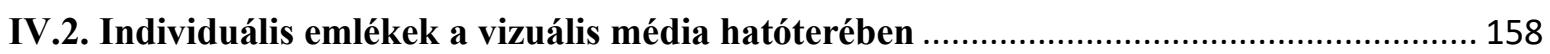

IV.2.1. A technikai képek hatása az önképre ....................................................................... 159

IV.2.2. A megőrzött pillanatok (anti)kultusza ................................................................... 162

IV.3. A kollektív emlékezés narratíváját meghatározó technikai kép.................................... 165

IV.3.1. A mediatizált technikai kép mint történeti forrás.................................................. 166

IV.3.2. Történelmi távlaton belül rekedve?................................................................. 170

IV.3.3. Képeknek kiszolgáltatott közösségi identitás?....................................................... 172

A fejezet összegzése: Egy vizuális kor identitásproblémái..................................................... 177

V. Helyünk a képek között - esélylatolgatások ....................................................180

Összegzés ................................................................................................................189

Felhasznált irodalom ...............................................................................193 


\section{Bevezető}

A kép maga a csoda. Az a tény, hogy észlelési és mentális képeink mellett képesek vagyunk olyan képek létrehozására, melyeket mások is láthatnak, egyik bizonyítéka az emberi nem nagyszerüségének. A fizikai képek tudatos megalkotásának képessége lehetővé teszi a nyomhagyást, a megörökítést, az elenyészés elleni küzdelmet, a halhatatlanságot, az idő uralását. Nem véletlen, hogy a kép évezredeken keresztül áhítatra késztette a szemlélőt és elmélyült koncentrációra tarthatott igényt. Ennek a csodálatnak azonban ma már nyoma sincs. A kép hétköznapivá vált, a tekintet elsiklik felette, hiszen mérhetetlen mennyiségben áll rendelkezésünkre. A vizuális infláció nyilvánvaló folyamata mellett és ellenére azonban napjaink embere minden korábbinál erősebben kötődik a képek világához: a képek készítése, publikálása és élvezete szükségletként van jelen az életében.

Vizsgálódásaim kiindulópontja egy korjelenség: az ember minden cselekedete, megmozdulása kapcsán hatalmas mennyiségü képi információ képződik és raktározódik. Jellemzően már nem csupán a jelentős eseményeket, hanem a hétköznapokban tapasztalt látványokat is megörökítjük. Az emberélet állomásait bőséges vizuális dokumentáció konzerválja a magzati kortól a temetési szertartásig. Ilyen mérvü dokumentációs aktusokra korábban soha nem volt példa. Az egyén ezáltal egy vizuális portfóliót sző önmaga köré, amely magában foglalja életútjának képi vetületét. E portfólió egyre többeknél napi rendszerességgel bővül, tágul, részletesen archiválva, hogy alanya mikor merre járt és mit csinált. Specifikus vonása a redundancia, hiszen minden apró változás és elmozdulás előidézi az új kép készítésének szükségletét. E portfóliók (szemben a hagyományos papírképekből álló családi albumokkal) jellemzően az egyénhez kötöttek, amit az is determinál, hogy elemeik többsége valamely közösségi oldalra szántan jön létre, az egyén ott létrehozott profiljához, virtuális énjéhez kapcsolódóan.

A folio latin eredetü kifejezés jelentése: lap, levél. A portfolio egy ebből eredeztethető olasz kifejezés, amely dossziét, dokumentumok összességét, gyüjteményt jelent. Noha legtöbbeknek a közgazdaságtan és az oktatás ötlik először az eszébe a szó hallatán, a kifejezés ismert a müvészvilágban is: a mappába gyüjtött képzőművészeti alkotások kollekcióját is nevezik így. A fényképezés kapcsán szintúgy gyakran halljuk: napjainkban a fotósok már nem csupán a modellek, de az átlagember számára is hirdetnek portfólió-fotózási lehetőségét, amely egy-egy képsorozat elkészítését takarja. A portfólió-fotózás során az alanyt különféle öltözetekben, pózokban, környezetben ábrázolják. 
Az individuumnak jól érzékelhető törekvése ez a mindenhol megmutatkozás. Így nem csupán a hivatásos fotósok révén, de ismerösei és önnön képkészítő tevékenysége révén is bővíti saját életútját leképező portfólióját. E kifejezést divatossága, hétköznapokban elterjedt használata mellett és ellenére is relevánsnak tartom annak a halmaznak, képkollekciónak a jelölésére, amely az egyes ember élete folyamán, a róla és általa készült képekből összeáll.

Úgy vélem, az emberi életút vizuális portfólióként való leképeződésének vizsgálata jó lehetőséget biztosíthat arra, hogy a posztfotografikus éra szülöttének létmódja megragadhatóvá váljék. Lehetővé teszi azt a komplexitást, amely a képi/ikonikus fordulat meghirdetése óta megkerülhetetlen igényként van jelen a képkutatásban, ugyanakkor mégis ad egy támpontot, vezérfonalat.

Flusser 1983-as, A fotográfia filozófiája (Für eine Philosophie der Fotografie) címü munkájában felveti, hogy egy fényképészet-filozófia kiindulási pontja lehet minden olyan filozófiának, amely az ember jelenlegi és jövőbeli létével foglalkozik. ${ }^{1}$ Rámutat, hogy az általa fotóuniverzumnak nevezett jelenséghalmaz bizonyos értelemben modellezi a posztindusztriális életet. Flusser fotóuniverzuma azonban az azóta eltelt bő harminc esztendőben számos változáson ment keresztül: elterjedt a digitális fotó, amely testetlen és soha nem tekinthetö késznek, csupán változataiban létezik. Az újmédia lehetőségeinek köszönhetően már bárki a nyilvánosság elé tárhatja az általa létrehozott képeket, így a tárolás háttérbe szorul a publikálási aktus javára, és a képek egyre kevésbé a jövőnek, sokkal inkább a jelennek készülnek.

Kutatásom célja, hogy ezeket a változásokat és a mögöttük felfejthető szimptomatikus, szellemi-kulturális folyamatokat sorra vegyem - egy konkrét kortünetre, a vizuális dokumentációképzésre koncentrálva, illetve abból kibontva. Flusser fent idézett gondolatából kiindulva úgy vélem, a képekhez való viszonyulás és a hétköznapjaink folyamatos leképezésének igénye (kényszere?), az emberi életek redundáns jegyeket mutató vizuális portfóliói sokat elárulnak korunkról, aktuális létmódunkról. Kutatásommal tehát mindenekelőtt a posztfotografikus érában élő ember létjellemzőiről, illetve az ember és kép viszonyának változásairól való gondolkodáshoz kívánok új szempontokat adni.

A képek hatalmas családjából mindenekelött a technikai képekre, azon belül is a privát célra készült (tehát nem a fotómüvészet és nem a hivatalos sajtófotó kategóriájába tartozó) fotókra szeretnék koncentrálni, amelyek ma már jellemzően nem tárgyként, hanem információként (mint digitális fotó) léteznek. Az egyén mindennapi életét dokumentáló fotók státusza, létmódja foglalkoztat, amelyre nézve meghatározó az a tény, hogy oroszlánrészüket

\footnotetext{
${ }^{1}$ Flusser, Vilém: A fotográfia filozófiája. Tartóshullám - Belvedere - ELTE BTK, Budapest, 1990. 61.
} 
eleve a nyilvánosság új színterére, a közösségi médiába szánja a készítő. A képek mediatizációjának folyamata kiemelt hangsúlyt kap vizsgálódásomban, hiszen az a tény, hogy a privátfotók is a médiatér részeivé váltak és széles nyilvánosságra tartanak igényt - ellentétben az újmédia előtti időszakkal - meghatározó jelentőségű. Egy olyan folyamatnak vagyunk tanúi, melynek során elmosódik a diskurzív médiumokra még jellemző privát/amatőr, illetve a nyilvánosságnak szánt/professzionális fotók közötti különbség és a dialogikus médiatér megnyílik az olyan képek irányába, amelyekről korábban azt gondoltuk, hogy csak az egyén és környezete számára bírnak jelentéssel és jelentőséggel. E mediatizációs folyamat konvergens a vizuális portfóliók tágulásával.

A posztfotografikus kort jellemzi, hogy a benne élő ember a képekbe kapaszkodik, képekben próbálja kifejezni magát, képekből próbálja felépíteni identitását, miközben jelentős mértékig irányítható is a képek által. E jellemzők köré csoportosítom azokat a problémaköröket, melyeket alaposabb vizsgálatnak vetek alá.

Az egyik problémakör, amelyet az említett vizuális portfóliók tükrében meg kívánok vizsgálni, az a képek általi meghatározottság létrejötte, mibenléte és kiterjedése. Szándékomban áll feltárni azt az ellentmondást, ami abban nyilvánul meg, hogy a poszfotografikus kor szülöttje egyfelől látszólag semmibe veszi a képeket, másfelől azonban függ állandó jelenlétüktől. A képek számára nem csupán élvezeti forrást, de olykor a természeti valóságot felülmúló jelentőségü tapasztalati forrást is jelentenek. Ennek kapcsán nem megkerülhető az a dilemma, hogy a mediatizált képek terében megélt valóság mennyiben felel meg a „valódi” valóságnak, és lehet-e két valóságról beszélni, vagy inkább ugyanazon valóság több síkjáról.

A második, megvizsgálni kívánt problémakör az ember képek általi irányíthatóságában ragadható meg. A portfóliók elemeit vizsgálva felmerül az a lehetőség, hogy azokra nem csupán az ember önmaga után hagyott nyomaiként kell tekintenünk, hanem egy kommunikációs aktus jeleiként kell értelmeznünk őket. Ebből kiindulva szeretném megvizsgálni, hogy e jelekre építve milyen esélyei lehetnek a sikeres vizuális kommunikációnak, e kommunikációs folyamatot milyen jelenségek zavarhatják meg, és a folyamat hogyan manipulálható.

A harmadik, nagy problémakör a mediatizált technikai képek identitásra gyakorolt hatását vizsgálja. Szeretnék rámutatni arra, hogy a vizuális dokumentáció mint mesterséges emlékezet erőteljes befolyást gyakorolhat az egyén önképére és arra, hogy egy közösség tagjai hogyan tekintenek a közösség múltjára. Akadályozhatja az idő munkáját, az emlékek szelektálását, a történelmi távlat megteremtésének lehetőségét, a múlt lezárását és a továbblépést. Ilyen értelemben a táguló vizuális portfóliók hatalmas terhet jelenthetnek az utókor számára. 
A téma aktualitásából következik, hogy a tendenciák kifutása még nem látható be, a tünetek megítélése nehézségekbe ütközik. Pontos prognózisok kimunkálása csak a tudományos kutatások hosszútávú programjaként képzelhető el. Dolgozatom záró fejezete épp ezért nem vállalkozhat többre, mint lehetőségek és válaszreakciók számba vételére, és a fentiekből következő, további kérdések körvonalazására.

Disszertációmat az alapfogalmak körbejárásával, a látás, a szemlélő és a kép mibenlétének problémakörétől indítom, többek között Erwin Panofsky, Rudolf Arnheim, Ernst Gombrich, Hans-Georg Gadamer, Jonathan Crary és Horányi Özséb gondolataira támaszkodva. Ezután a képek természetével és csoportosítási lehetőségeivel foglalkozom, melyből kirajzolódik a képek köré épülő tudományterületi illetékességi vita - ehhez, valamint a képi fordulat megvilágításához Hans Belting, Arthur C. Danto, W.J.T. Mitchell, Gottfried Boehm és Horst Bredekamp meglátásait hívom segítségül, kiegészítve Nicholas Mirzoeff és Martin Jay vizuális kultúrával kapcsolatos elméleteivel.

Ezt követően a képi meghatározottságot mint tünethalmazt igyekszem feltérképezni. A tünetekhez vezető út, a képek általi meghatározottság kialakulása kapcsán Walter Benjamin, Vilém Flusser, Roland Barthes, Susan Sontag, Bán András, valamint Szilágyi Gábor és Kolta Magdolna fotótörténészek írásaira támaszkodom, kiegészítve Lehmann Miklós digitális képre vonatkozó téziseivel. A tünetek megragadásához egy példát hívok segítségül: bemutatom, hogyan változott meg az emberi arcképhez való viszony a fotográfia feltalálásával, majd az újmédia kialakulásával. A képek mediatizációjának vizsgálata kapcsán Lev Manovich és Roger Silverstone, a média képei és a valóság képei közötti viszony megvilágításhoz pedig Walter Lippmann, Ben Haig Bagdikian, Niklas Luhmann és Tóth Benedek megállapításaiból indulok ki.

Ezután a vizuális portfólió elemeinek kommunikációban betöltött szerepével foglalkozom. A kép és kommunikáció, kép és szöveg problémakör szakirodalmából Ludwig Wittgenstein, Nelson Goodman, Nyíri Kristóf, Søren Kjørup, Mircea Eliade, Kepes György, valamint Kibédi Varga Áron meglátásait emelem ki. A médiamanipuláció, a médiaagresszió, a látás média általi determináltsága vonatkozásában George Gebner, Albert Bandura, Marcel Frydman; az emlékezet és identitás vonatkozásaiban Alan Baddeley, Jan Assman, Antik Sándor és Lewis Mumford; a képek általi meghatározottság lehetséges kimeneteleinek taglalása kapcsán Umberto Eco, Herbert Marcuse, Marshall McLuhan, és Jean Baudrillard gondolatait idézem meg. 


\title{
I. A képekhez való elméleti közelítés nehézségei az alapfogalmak tükrében
}

\begin{abstract}
„Ha az archeológia és a müvészettörténet történeti képtudományként újitották meg hagyományaikat, ha a filmtudomány az elbeszélés helyett immár a filmek képszerüségét állitja elötérbe, ha a filozófia a kép reflexióját részesíti elönyben, ha az irodalomtudomány irás és kép kölcsönviszonyát elemzi, ha a történettudomány felmenti a képi forrásokat az illusztráció ódiuma alól, ha a tudománytörténet a tudományok vizuális feltételeit hangsúlyozza, ha a jogtudomány a jog ikonológiáján dolgozik, ha a matematikában a Bourbaki-csoport ikonoklazmusával szemben álló kijelentés, a „, Seeing is believing” érezteti hatását, ha a biológia Darwin óta most elöször tárgyalja a szépséget mint a kiválasztódás kritériumát, s ha a természettudományok minden területén fellépö számitógépes vizualizáció elemzés tárgyává válik, mindez azt jelzi, hogy a kutatás területén is végbemegy az a mélyreható s a kultúra egészében érzékelhető fordulat, amelyet a modern képi technikák és a vizuális részvétel vágya hivtak elö. "2
\end{abstract}

Horst Bredekamp

A tudományos párbeszédében egyre nagyobb hangsúlyt kap az a jelenség, amelyet Gombrich vizuális kornak (visual age) ${ }^{3}$, Guy Debord látványtársadalomnak (La société du spectacle) ${ }^{4}$, Gottfried Boehm ikonikus fordulatnak (ikonische Wende) ${ }^{5}$, W.J.T. Mitchell képi fordulatnak ${ }^{6}$ (pictorial turn) nevez. Párhuzamosan azzal, ahogy növekszik a minket nap mint nap körülvevő, figyelmünkért versenyt folytató képek száma, egyre fokozottabb az érdeklődés a képek világa iránt - számos tudományterület irányából. Míg az előző évezred végén leginkább a művészettörténet jussa volt a képek történetének, helyzetének, üzenetének, jellemzőinek elemzése, mára nyilvánvalóvá vált, hogy bőven talál magának e területen feltárandó problémaköröket a médiatudomány, a szemiotika, a filozófia - azon belül az etika, a hermeneutika, az esztétika - a szociológia, az antropológia, a pszichológia, sőt akár a neurobiológia is. Mégis azt látjuk, hogy ezen tudományterületek művelői mintha elbeszélnének egymás mellett, nem fordítanak egymásra elegendő figyelmet még ma sem, amikor egyre több egyetem és kutatóintézet nyit a vizuális kultúrakutatás, az ikonológia vagy a Bildwissenschaft felé. A képekkel kapcsolatos szakirodalom egyre duzzad, ám sokszor kerülnek terítékre

\footnotetext{
${ }^{2}$ Bredekamp, Horst: Fordulópontok. Az iconic turn ismertetőjegyei és igényei. In: Nagy Edina (szerk.): A kép a médiamüvészet korában. L’Harmattan, 2006. 13.

${ }^{3}$ Gombrich, E.H.: The Visual Image. In: Scientific American, 1972. 85.

${ }^{4}$ Debord, Guy: La Société du spectacle. Buchet/Chastel, Párizs, 1967.

${ }^{5}$ Boehm, Gottfried: Die Wiederkehr der Bilder. In: Boehm, Gottfried: Was ist ein Bild? München, Wilhelm Fink Verlag, 1994, 14.

${ }^{6}$ Mitchell, W.J.T.: Pictorial turn. In: Picture Theory. The University of Chicago Press. Chicago, IL, United States, 1994., 11.
} 
korábban már bebizonyított vagy épp megcáfolt nézetek, és tálaltatnak újabbak anélkül, hogy reflektálnának a korábbiakra.

E divergenciának több oka is van. Az egyik legkézenfekvőbb mentség az egyidejűség: mivel az 1980-as évek vége - Belting, Danto, Mitchell ás Boehm újszerű képmegközelítési nézeteinek publikálása ${ }^{7}$ - óta egyre többen foglalkoznak a képek világával, jóformán nincs idejük az újabb elméleteknek az elterjedésre, hiszen rögtön ott lesz egy következő. Ráadásul a kutatók igyekeznek mindig az aktuális problémakörökre reflektálni, és mivel a képek, a média, a virtualitás világának állandóan változó környezetében folyamatosan ütik fel a fejüket az újabb és újabb jelenségek, nem könnyü velük lépést tartani. Az pedig különösen nagy csúszást jelent, mire az oktatás is reagál az új jelenségekre és az azokra reflektáló elméleteket magába integrálja.

A másik ok pedig az, hogy a képeknek még mindig nem állt össze igazán egy egységes, koherens tudománya. Más kérdés, hogy egyes kutatók, például W.J.T. Mitchell szerint ez nem is baj, hiszen „nem lenne szerencsés, ha a vizuális kultúra kutatás túl gyorsan, vagy akár egyáltalán intézményesülne. A vizuális kultúra mint koncepció nagy érdeme az, hogy tendenciájában nem diszciplinált, inkább problematika, mint jól meghatározott elméleti tárgy"8 - írta 1995-ben a chicagói egyetem professzora. Ám ez sem mentség arra, hogy még Mitchell kijelentése után bő 20 évvel is inkább a részterületeken zajlanak a kutatások, melyek művelöi csak ritkán és nagy óvatossággal lépnek át a többi területre. E félelem persze valahol érthető, mert hiába válik egyre több témában népszerüvé, mondhatni divatossá az interdiszciplináris megközelítés, bőven akad bírálója is: a tudományos világ gyakorta nehezményezi a szükségszerü felületességet - nem mindig alaptalanul.

Az sem biztos, hogy helyesen fogalmazunk, amikor azt mondjuk: még nem alakult ki az egységes képtudomány. Bacsó Béla gondolatát is érdemes megfontolni, aki 2013-ban úgy látja, „a képi elem elötérbe kerülése olyannyira széleskörüvé vált, hogy már aligha lehet egyetlen Bildwissenschaftról beszélni." "Szétaprózódott volna a terület, mielött igazán egységessé formálódhatott volna? Ám a behatárolás nehézségei feletti aggodalom mellett nem szabad megfeledkeznünk arról, milyen izgalmas távlatokat nyitott ezen új terület (vagy nevezzük

\footnotetext{
${ }^{7}$ Természetesen az ő munkásságuk sem előzmények nélkül való, számos fontos, a képek helyzetével kapcsolatos, nem feltétlenül kizárólagosan müvészettörténeti megközelítésű gondolat született korábban is. Mégis úgy tünik, a '80-as évektől vett igazán lendületet az újfajta, nem egyértelmüen müvészettörténeti megközelítésü képkutatás mindenekelött Mitchell Iconology (1986), Belting The End of the History of Art? (1987) és Danto The end of art (1988) című műveinek hatására.

${ }^{8}$ Mitchell, W.J.T: Interdiszciplinaritás és vizuális kultúra. In: Magyar Építőmüvészet, http://meonline.hu/vizualiskultura/interdiszciplinaritas-es-vizualis-kultura-kutatas/ (letöltés: 2017.10.10.) Az eredeti mü (Interdisciplinarity and Visual Culture) 1995-ben jelent meg: Art Bulletin, 77.évf. 4.sz, 540-544.

${ }^{9}$ Bacsó Béla: A kép-tudomány margójára. In: Studia Litteraria: Kép, látvány, szöveg. 2013/1-2. LII. évfolyam, 9.
} 
Mitchell nyomán problematikának?), amely óriási szabadságot ad a rá merészkedőknek épp azért, mert nem rögzült be a hivatalos tudományos struktúrába, inkább úgy fogalmazhatnánk: fórumot biztosít a diszciplináris programok között.

A fejezet első részében megvizsgálom, hogy melyek azok az alapfogalmak, amelyeken nem lehet átlépni, amikor a képekröl beszélünk - teszem ezt azzal a céllal, mert úgy vélem, a definiálásuk kapcsán fellépő nehézségek is azt fogják alátámasztani, hogy van létjogosultsága a több diszciplina irányából való megközelítésnek. Az olyan alapfogalmak tisztázása kapcsán, mint a tapasztalás, a vizuális észlelés, a megismerés és a befogadás, vagy egyáltalán: a kép (mint tárgy, mint aktus, mint konstitúció) definiálása, kategorizálása kapcsán szembetűnő lesz, mennyire lehetetlen vállalkozás ezen fogalmakat egyetlen tudományág szemszögéből vizsgálni. E fogalmak vizsgálata során óhatatlanul bele fogunk ütközni a médiatudomány és a művészettudomány közötti konfliktusokba, a vizuális kultúra területét körbekerítő törekvések kudarcaiba, vagy abba a problémába, hogy hová is tartoznak azok a képek, amelyek nem tekinthetők műalkotásnak. Fel fog merülni a kérdés, hogy szükség van-e egy új, egyesített képtudományra, milyen lehetőségeink vannak ennek megteremtésére és milyen kockázatokkal kell számolnunk.

Úgy vélem, a fejezet folyamán körvonalazódni fognak azok a tünetek, amelyek jelzik: eljárt az idő azon opció felett, hogy a képekhez egyetlen tudományterület részterületén zászlót verve közelítsünk. Természetesen számolnunk kell sok-sok buktatóval, amit az interdiszciplinaritás magában hordoz, ám úgy vélem, e kockázatokat vállalnia kell a jövő szakembereinek és gondolkodóinak.

\section{1. Úton a képek felé: tapasztalás, látás, befogadás}

„A látás tényleg a szem dolga, de ezt a szót szoktuk a többi érzékre is alkalmazni, mikor valamit meg akarunk ismerni. Senki se mondja: hallgasd, hogy fénylik! - vagy: szagold csak, hogy ragyog! (...) - mert minden ilyenröl azt mondjuk, hogy megnézzük, megszemléljük, meglátjuk." 10

Aurelius Augustinus

Az alapfogalmak körüli problematizálás, a képek mibenlétének, hovatartozásának meghatározására és a kategorizálásukra tett kísérletek felvázolása előtt mindenképpen érdemes

\footnotetext{
${ }^{10}$ Szent Ágoston vallomásai (ford.: Vass József). Budapest, Szent István Társulat, 1995., XXXV. fejezet: $A$ kiváncsiság kisértései. 159.
} 
elidőzni az észlelés témaköre körül. Kitekintést kell tennünk azon kérdéskörök irányába, hogyan tapasztaljuk, hogyan ismerjük meg és végső soron hogyan fogadjuk be a képeket.

Itt szinte azonnal beleütközünk abba a problémába, amely a természettudományok és a társadalomtudományok között húzott határvonal nehéz átjárhatóságából adódik. Noha évről évre újabb, jelentős neurobiológiai kutatási eredmények látnak napvilágot, még mindig igen keveset tudunk arról, hogy pontosan hogyan zajlik a képek észlelése, milyen agyi folyamatok felelösek a megőrzésükért, tárolásukért, reprodukálásukért, újrakonstruálásukért. De még a meglévő ismereteket is nehéz felhasználni a képkutatásban, hiszen e kutatások nehezen találnak csatornát a társadalomtudományokhoz. Utóbbi művelői pedig sok esetben tartanak attól, hogy belemélyedjenek az agykutatás és az idegrendszeri folyamatok kihívásainak megismerésébe. Pedig, ha visszább megyünk a tudománytörténetben, nyilvánvalóvá válik, hogy a tapasztalás, észlelés vagy éppen a látás témája nagyon is foglalkoztatta, sőt, megosztotta a bölcselőket. Gottfried Boehm egyenesen így fogalmaz: „A korai kezdetektől fogva kialakult a szétválasztás ama művészete, amely a magasabb és az alacsonyabb, a tiszta és az érzéki észlelet közötti rangbeli különbséget tette az európai gondolkodás ismertetőjegyévé."11

Így mindenképpen indokolt lehet a képek felé vezető útra a tapasztalás filozófiai fogalmától elindulni. E fogalom főbb, vonatkozó értelmezési irányainak áttekintése után sorra veszem a vizuális megismerés problémaköreit, végül pedig a szemlélő pozícióját vizsgálom meg - mindezek után térhetek majd rá a képek ontológiai státuszának és hovatartozásának meghatározása körüli dilemmákra.

\section{I.1.1. A tapasztalat filozófiai értelmezési lehetőségeinek alapvető irányai a képkutatás felé vezető úton.}

A tapasztalat mibenlétének vizsgálata egyfelől azért elengedhetetlen a képek elméleti megközelítési lehetőségeinek feltérképezésében, mert azt látjuk, hogy a (technikai) képek sokasodásával és a média térnyerésével az információszerzési és tapasztalatszerzési szokások gyökeresen átalakulnak. Egyre inkább a kutatások homlokterébe kerül az a jelenség, hogy az ember tapasztalatai nagy részét már nem a valóság közvetlen, empirikus szintjéröl, hanem a képek és a média teremtette másodlagos valóságszférából nyeri. E jelenség (melyre majd a II.3.3. alfejezetben térek ki részletesebben) ismeretelméleti és ontológiai vetületeinek vizsgálata segíthet felkészülni egy óriási változásra, amit a képekbe burkolt élet, a természeti környezettől való elszakadás, a virtualizálódás hoz magával. Másfelől: a képek észlelésének

\footnotetext{
${ }^{11}$ Boehm, Gottfried: Látás. Hermeneutikai reflexiók (Ford.: Kukla Krisztián) Vulgo, 1999/II 1/2. 218-231.
} 
folyamata, a látás az érzéki tapasztalás egyik módja. Ezért, ha a képek befogadásának folyamatával kívánunk foglalkozni, a tapasztalat fogalmának megközelítése megkerülhetetlen.

A magyar tapasztalat szó a tapasztal igével kifejezett cselekvés eredménye. Görög megfelelője az empeiria (megfigyelés, tapasztalás), latin megfelelője pedig az experientia (kísérlet, próba, tapasztalás) kifejezés, és a hétköznapi szóhasználatban a külvilágról az érzékszervek útján szerzett észleletet, illetve az egyszerű megfigyelést értjük alatta. Definiálható úgy is, mint az érzékelés által felfogott objektív világ visszatükrözése az emberi tudatban. A különféle értelmezések többek között abban térnek el egymástól, hogy a tapasztalat folyamatában az érzékszervek munkájára vagy a tapasztalat elmében való megkonstruálódására, tehát az érzéki vagy az értelmi megismerésre helyezik a hangsúlyt. Különbségek vannak a tapasztalás mint folyamat lezajlásának értékelésében is: az érzékszerveket passzív receptoroknak tekintő értelmezés mellett létezik egy olyan megközelítés is, amely a tapasztalást aktív, alkotó folyamatként értelmezi.

A fogalom kultúrtörténeti vonatkozásait vizsgálva visszamehetünk egészen Platónig, aki szerint a tapasztalat világában minden változik, ezért a tudás valódi tárgya a tapasztalati világon kívül keresendő: az ideák birodalmában. Különbséget tesz a tapasztalatból származó és a tapasztalattól független tudás között, utóbbit tartva magasabb rendűnek. Az érzékiség és különösképpen a látás elleni polémia Platón óta újra és újra megjelenik a filozófiában, és ettől kezdve többféle tapasztalat-fogalommal találhatjuk szembe magunkat.

Arisztotelész úgy vélte, az észrevételből emlék jön létre, és csak több, azonos fajtájú emlék összességéből áll össze az empeiria, és az ezt követő lépésben juthatunk el az ítélethez. Platón idealizmusához képest ő védelmébe vette az érzéki észrevételt: nem az érzékek csalnak, hanem ezek gondolkodásunk általi értelmezései - ugyanakkor a puszta megfigyelésnél magasabb rendünek látta azok gondolkodás általi összegzését. „A tapasztalat az egyes esetekre vonatkozó tudás, a tudomány pedig az általánosra vonatkozik. (...) A tapasztalat emberei ugyanis tudják a micsodát, de nem tudják a miértet, az elméleti tudósok pedig a miértnek és az oknak ismeröi” - hangzik a közismert idézet. ${ }^{12}$

Arisztotelész értelmezésével szemben az újkori empirizmus már egyetlen észrevételt is tapasztalatnak nevez. A szenzualizmus egyenesen lebecsüli az értelmi megismerés, az aktív gondolkodás szerepét a valóság megismerésében, elveti a velünk született fogalmakat, és a megismerést az érzéki észlelésre vezeti vissza.

\footnotetext{
${ }^{12}$ Arisztotelész: Metafizika (ford.: Halassy Nagy József), Lectum Kiadó, Szeged, 2002. I. könyv, Első fejezet, 38.
} 
A fogalom egy újabb értelmezése pedig Kanthoz köthető: a tapasztalat a maga teljes értelmében csupán tapasztalati itélet. A szubjektív érvényességgel bíró puszta észleleti itélettől eltérően a tapasztalat adottságait Kant az értelem a priori fogalmain keresztül egy szigorúan általános érvényü ,tárgyi” ismeret alá sorolja be. ${ }^{13}$

A fogalom a tapasztaló ember oldaláról is megközelíthető: ilyen értelemben tapasztalatnak nevezhető az embernek a külvilágra való gyakorlati ráhatása alapján felhalmozódott ismeretek összessége, e ráhatás észleleti, gondolati eredménye, a külvilág érzéki tükröződése - mely másodlagos az objektív realitáshoz képest. Mindezek már előrevetítik azt a kettősséget, amely az érzéki és az intellektuális szemlélet különbségében nyilvánul meg, és elvezet ahhoz a hasadáshoz, ${ }^{14}$ amely Boehm szerint a látás tevékenységét és világát jellemzi: az ismeretekkel terhes szférában a szem nemesi rangra tesz szert, míg az érzéki szférában a szenvedélyek kalauzolnak. ${ }^{15}$

Ám mielőtt a tapasztalat tágabb halmazából kiemelnénk a látást, még néhány fontosabb, a téma szempontjából releváns irányt meg kell említenünk. Hans-Georg Gadamer bevezette a hermeneutikai tapasztalás fogalmát, amely a müvészet, a filozófia és a történelem tapasztalatát foglalja magában, és az értelmezési mozzanatot állítja középpontba. Gadamer szerint az objektivitásra törekvő, egzakt, bizonyításon alapuló tudományos tapasztalás mellett más lehetőség is nyílik a megismerésre. A hermeneutikai módszerről azt állítja, „,ezekben a tapasztalásmódokban olyan igazság nyilvánul meg, amely a tudomány módszeres eszközeivel nem verifikálható.”16 Boehm szerint a hermeneutikai kritika értelme többek között abban áll, hogy szembehelyezkedünk az előfeltétel-mentes látás eszméjével, és felhívjuk a figyelmet arra, hogy fogalmaink és megismerés-modelljeink vizuális meghatározottsága olyan előzetes döntéseket foglal magában, amelyek kihatnak a megismerés szintjére. Ám hozzáteszi: ott azonban gyakran észrevétlen marad meghatározó erejük. ${ }^{17}$

\footnotetext{
${ }^{13}$ Kant, Immanuel: A tiszta ész kritikája, Atlantisz Könyvkiadó, 2009., 51-52.

${ }^{14}$ E szétválasztás tetten érhető a XIX. század közepének magyar nyelvállapotát tükröző Czuczor-Fogarasi-féle szótár tapasztalás szócikkben (Czuczor Gergely - Fogarasi János: A magyar nyelv szótára, 6. kötet, Athenaeum, Budapest, 1874. 79-80.) is: „A tudomásnak, illetőleg a benyomásnak azon neme, melynek forrását a bel vagy kül érzékekre ható tárgyak teszik." Ennek ellentéteként nevezi meg a szótár az elmélkedést, elmélést, mint az elmének közvetlen müködését. A tapasztalás eredménye a tapasztalat, az elmélésé az elmélet. A tapasztalat tehát „a tapasztalás által szerzett ismeret, tudomány vagy érzelem, érzet, melyet a tapasztalás támasztott bennünk.” Érdekesség, hogy a szótárban egy tapasztalász szócikk is szerepel: mint olyan bölcselő, tudós, aki elveit, tudományát csak a tapasztalt tényekre alapítja - utalás az empiristákra.

${ }^{15}$ Boehm, Gottfried: Látás. Hermeneutikai reflexiók (Ford.: Kukla Krisztián) Vulgo, 1999/II 1/2. 218-231.

${ }^{16}$ Gadamer, Hans-Georg: Igazság és módszer. Egy filozófiai hermeneutika vázlata. (Fordította: Bonyhai Gábor) Gondolat Könyvkiadó, Budapest, 1984. 21.

${ }^{17}$ Boehm, Gottfried: Sehen. Hermeneutische Reflexionen. Internationale Zeitschrift für Philosophie, 1992/1. 51. (Fordította Kukla Krisztián) Vulgo, 1999 / II 1/2. 218-231.
} 
Az eltérő értelmezésekben azonban közös pontokat is találhatunk. Az egyik ilyen, hogy a tapasztalat egyfajta receptivitást, felfogó-, befogadóképességet igényel. Van benne valami adott, ami nem a gondolkodás teljesen tudatos folyamatai által jön létre. Elmondható róla az is, hogy a tapasztalatban megismert létező mindig egy konkrétan létező egyes, és nem valamely absztrakt fogalomban megmutatkozó általános, lényegszerű tényállás - ám ennek igazolhatóságához figyelembe kell vennünk azt is, hogy a filozófia megkülönböztet külső és belső tapasztalást.

A külső tapasztalat elsősorban a minőségi és mennyiségi jellegü érzéki adottságokra irányul, amelyeket önkéntelenül valamiféle észrevevésünktől függetlenül létező dologgal hozunk kapcsolatba. Ez lényegében egy érzéki megismerés, melynek során e magánvalóan létező dolgot a tapasztalat tárgyaként jelöljük meg. A belső tapasztalás azonban saját lelki aktusainkkal és lelkiállapotunkkal kapcsolatos élményeinket jelenti. ${ }^{18}$

Az emberi tapasztalás elméleteire nagy hatást gyakorolt a kognitív pszichológia, amely az emberi megismerési folyamatot egységes elvek szerint rendezi az észleléstől az emlékezeten, a figyelmen, az alakfelismerésen és a problémamegoldáson át az értelmi fejlödésig. A kogníciónak nevezett, a valóság megismerésére és megértésére szolgáló tudatos törekvés az információ-feldolgozás folyamatát a rendszerben, azaz a pszichikumban áramló információ nyomon követésével vizsgálja.

Napjainkra a tapasztalatszerzés, tapasztalás, megismerés kérdéskörei elválaszthatatlanul összekapcsolódtak az információ fogalmával is. Korunk egyik paradigmája, az információ- és rendszerelmélet az érzéki megismerés vizsgálatát is áthatotta: e felfogás szerint a környezetről nyerhető érzetek információkként szerepelnek, és ebben a folyamatban az ember információátvivő berendezésként vesz részt. Az élőlények e gondolkodás értelmében információ-feldolgozó rendszerekként müködnek. Az ennek jegyében zajló kutatások arra keresik a választ, hogy hogyan dolgozza fel az ember a külvilágból érkező tapasztalatait, hogyan és hol tárolja ismereteit. (Az információfilozófia ${ }^{19}$ azonban, amely a filozófia, az informatika, a számítástechnika és az információtechnológia metszéspontjaiban felmerülő fogalmi kérdésekkel foglalkozik, még nagyon friss terület, irányai most vannak kialakulóban, irodalma nagyrészt vitairodalom.)

\footnotetext{
${ }^{18}$ Brugger, Walter: Filozófiai lexikon. Szent István Társulat, Budapest, 2005. 411.

$19 \mathrm{Az}$ információfilozófia kifejezés megalkotását többnyire Luciano Floridinek tulajdonítják, aki szerint az információ és az ahhoz szorosan kapcsolódó területek határán felmerülő kérdések tisztázásához a fogalmi keretrendszer továbbfejlesztésére van szükség. Lásd: Floridi, Luciano: What is Philosophy of Information. Metaphilosophy, 33 (1/2). 2002.
} 
Noha a legtöbb vélekedés a tapasztalásra úgy tekint, mint a kézzel fogható dolgokról és jól körülírható jelenségekről szerzett érzéki benyomásra, meg kell jegyeznünk, hogy egyes gondolkodóknál, illetve a vallási ideológiákban gyakran találkozhatunk a transzcendentális tapasztalat kifejezéssel is. Ez alatt egyfajta szellemi öntudatot érthetünk, amely az igazság megismerésének feltétele, melyben nagyobb szerep juthat a velünk született fogalmaknak. ${ }^{20}$

Jelen esetben azonban a dologi tapasztalás, az érzékszervek révén szerzett benyomások vizsgálata révén közelíthetünk témánkhoz. Ezen tapasztalatok közül most vizsgáljuk meg alaposabban azokat, amelyek a látásunk által befogadott információk révén jönnek létre.

\section{I.1.2. A látás mint filozófiai probléma néhány vonulata}

A megismerésnek tehát két fokozatát, két szintjét szokás elkülöníteni: az érzéki és az értelmi megismerést. Az érzéki megismerés folyamán azokat a benyomásokat dolgozzuk fel, amelyeket érzékszerveink által a minket körülvevő világból szereztünk. Az érzéki megismerést ebben a megközelítésben tágabb halmaznak tekinthetjük, mint az érzéki tapasztalást, amennyiben az érzékelőképességünk (species impressa) által a benyomásokat tevékeny módon tudatossá tesszük. Láttuk, hogy ez a legtöbb gondolkodó szerint még messze van a lényegi dolgok megismerésétől vagy az önmagunkról való tudástól, amelyre csak az erre épülő szinten, az értelmi megismerés szintjén juthatunk el, amelyben a szubjektum eljuthat önmagához, és a létről való gondolkodáshoz - más megközelítések szerint a befogadás és a megismerés egymástól nem elválasztható tevékenységek. A látás mibenlétének meghatározása körüli, legnagyobb konfliktus is ezzel áll összefüggésben: Mi a látás? Fiziológiai folyamat, amely a szempár tulajdonosának szubjektumától függetlenül megy végbe? Vagy megismerő tevékenység, amelyben aktívan részt vesz a szubjektum is? Ha az utóbbi mellett tesszük le a voksunkat, akkor feltételezhetjük, hogy külső behatások is érhetik a látást, az kontextusba kerülhet, és ily módon történeti konstrukcióval is bírhat.

A kérdések megválaszolásához közelítsünk a témához elsőként a fiziológiai folyamat irányából! A látás fogalma alatt hétköznapi értelemben a vizuális információ feldolgozását értjük, amelynek fó célja a tárgyak azonosítása, és azok közvetlenül nem észlelhető tulajdonságainak felismerése. A látás a legfontosabb támaszunk a testünk mobilizálásához és a manuális cselekvéseink vezérléséhez, hiszen a látásunk révén mérjük fel a körülöttünk lévő teret és az abban elhelyezkedő tárgyakat. Ily módon a tapasztalatok begyüjtésének is

\footnotetext{
${ }^{20}$ Brugger, Walter: Filozófiai lexikon. Szent István Társulat, Budapest, 2005. 411.
} 
meghatározó feltétele. (Mindez természetesen csak az ép látású emberre igaz, a látássérültek esetében nagyobb feladat hárul az egyéb érzékszervekre.)

A látásnak mint fiziológiai-optikai folyamatnak a kulcsa a fény, a világosság - amely fogalmak nem véletlenül váltak a tudás (akár a végső tudás, a transzcendens hatalom, az isteni) szimbólumává. Az információt a tárgyakról visszaverődő fény közvetíti a szemünk számára, de a fényjelenségeknek csak egy része érzékelhető az ember által. A láthatóság tartománya a prizma által felbontott fehér fény spektrumfényeit tartalmazza.

A látásban mint biológiai folyamatban két szervünk játszik kulcsfontosságú szerepet: a szem, amely számára a fény közvetíti az információt, és az agy, ahol ezek az információk feldolgozásra kerülnek. A szem a látás természetes optikai készülékének tekinthető, amelynek segítségével megvalósul a külvilág kínálta látvány észlelése. A szem hátsó részén található a retina, ahol a fény a fotoreceptor-sejtek csapjaiban és pálcikáiban idegi jellé alakul. Ezek a jelek a bipoláris sejteken keresztül a retina nagy ganglionsejteihez jutnak. A ganglionsejtek nyúlványaiból alakul ki a látóideg, melynek kereszteződésén át a rostok a látókötegben folytatódnak, majd az agykéreg megfelelő helyeire, a látókéreghez vezetik az ingerületeket.

Nagyon leegyszerüsítve tehát értelmezhetjük a látás fogalmát úgy, mint az információk agyunkba áramlásának egyik módozatát. Mint ilyen, nagyobb jelentősége van, mint a többi módozatnak, hiszen az ép érzékszervekkel rendelkező ember a külvilágból származó információk mintegy 60-80 százalékát látása révén érzékeli. A szem a környezetben szerzett tapasztalatok leggyorsabb adatátvitelét biztosító érzékszervünk. Ráadásul az emberi agy mintegy 40\%-a a látással foglalkozik. A hallás, tapintás és ízlelés útján szerzett ismeretek és tapasztalatok mindössze $20-40 \%$-át teszik ki a megismerő tevékenységnek. ${ }^{21}$ A vizuális empíriának tehát mindig kulcsfontosságú szerepe volt a tapasztalatszerzésben. De beszélhetünk-e ennek kapcsán a szubjektum szerepéröl?

Püthagorasz követői azt tartották, az értelem úgy ismeri fel az alakot és a színt, hogy a lélek sugara a pupillán keresztül eléri a tárgyat és letapogatja azt, Epikurosz és követői pedig úgy vélekedtek, hogy az ember a környezetében levő tárgyakról leszakadt képet - egy légies ködön keresztül - a pupilláján át érzékeli. Platón úgy vélte, hogy a lélekböl és a tárgyról jövő sugár találkozik a pupillánál, és ezáltal formálódik a tárgy árnyképe. Arisztotelész a Lélekfilozófiai irásokban arra utal, hogy az érzékelhető formák a tárgyakból erednek, és

\footnotetext{
${ }^{21}$ Kárpáti Andrea: A látás mint érzékelés. In: Bubik Veronika (szerk.): Vizualizáció a tudománykommunikációban. Eötvös Loránd Tudományegyetem, 2013. $\mathrm{http} / /$ elte.prompt.hu/sites/default/files/tananyagok/VizualizacioATudomanykommunikacioban/ch02s02.html (letöltés: 2017.10.22.)
} 
pecsétgyürüként nyomódnak bele érzékszerveink viaszhoz hasonló receptoraiba. ${ }^{22}$ Szent Ágoston megállapítja, hogy ,a szem megismerés dolgában valóságos király a többi érzékszerv közt”. A Vallomásokban írja, hogy az érzékek tapasztalati munkáját a Szentírás általában a „szemek kívánságának” nevezi; az érzékek ugyanis, mikor valamit meg akarnak ismerni, a hasonlatosság alapján a látás munkáját tulajdonítják maguknak, az pedig elsősorban a szem dolga. $^{23}$

Roger Bacon pedig így fogalmaz: „Minden ható ok saját ható ereje révén hat, amelyet a vele határos anyagra gyakorol, miképp a nap fénye hatást gyakorol a levegőre. S ezt a ható erőt „hasonmásnak”, „képmásnak”, „érzékelhető formáknak” hívják, és még sok más névvel is illetik. (...) Ez az érzékelhető forma hozza létre az összes hatást a világban, mert hat az érzékszervre, az értelemre és mindenre a dolgok keletkezésének világában."24

A kora újkori filozófusok egyik kedvelt kutatási területe volt az optika: Kepler, Descartes, Hobbes, Berkeley mind kiterjedt müveket szenteltek a látáselméleteknek, amelyek a felvilágosodással kezdtek betagozódni a bölcselet, illetve az optika mint természettudomány problémaköreibe. George Berkeley volt az, aki rámutatott: a filozófiai látásmódot meg kell különböztetni a természettudományostól. Úgy vélte, az optikában megfigyelhető paradoxonok a filozófiai és a természettudományos kérdések összekeveréséből adódtak. Érdemes itt megemlíteni Locke és Berkeley vitáját, amely termékenynek bizonyult a látáselméletek további fejlődésére nézve. John Locke szerint az érzékelhető objektumok reális léttel bírnak a valóságban, mely különbözik az ideáinktól. Locke az idea fogalmát úgy értelmezi, mint egyfajta lenyomatot. George Berkeley 1709-ben publikált Értekezés a látás új elméletéröl ${ }^{25}$ címü tanulmányában egy filozófiai észleléselméletet körvonalazott, és Locke szóhasználatával élve azt állította, hogy az ideák, pontosabban az észlelés ideái az elmében vannak, az észlelés tárgyát ezek az ideák alkotják. Viszont nem fogadta el Locke azon állítását, hogy léteznek közös és absztrakt ideák. Berkeley később Locke absztrakt idea-tézisének kritikájából fejlesztette ki saját álláspontját. Értekezés az emberi ismeret alapelveiről címü, 1710-es művében már nem csupán a másodlagos minőségekről (szín, hang, illat) jelenti ki, hogy csupán az elmében léteznek, de

\footnotetext{
${ }^{22}$ Az ókori gondolkodók legfontosabb, látással kapcsolatos megállapításait összegzi: Szpilczyński, Stanisław: $A$ látás kérdése Witelon (Vitellio) Peri Optices (1275) címü munkájában. Orvostörténeti Közlemények, 87-88. 1979. 219-222.

${ }^{23}$ Szent Ágoston vallomásai (ford.: Vass József). Budapest, Szent István Társulat, 1995., XXXV. fejezet: A kiváncsiság kísértései. 159.

${ }^{24}$ Bacon-t idézi W.J.T. Mitchell Iconology című könyvében, David C. Lindberg: Theories os Vision from Al-Kindi to Kepler címü müvére hivatkozva. Magyar fordítás: Szönyi György Endre, Szauter Dóra: A képek politikája, W.J.T. Mitchell válogatott írásai. Jate Press, Szeged, 2012.

${ }^{25}$ Berkeley, George: Értekezés a látás új elméletéröl (Ford.Faragó Szabó István) In: Tanulmány az emberi megismerés alapelveiröl és más irások. Gondolat, 1985.
} 
az elsődleges minőségekről (kiterjedés, nagyság, szám, mozgás) is. „Lehetetlen, hogy szín, kiterjedés vagy bármely más érzéki minőség az elmén kívül, valami nem gondolkodó dologban létezzék, azaz igazság szerint nincs olyasmi, amit külső objektumnak nevezhetnénk." - írja. ${ }^{26}$

A látás fiziológiai folyamatának feltárása a továbbiakban jellemzően a természettudományos módszerek bevetésével zajlott, ám a látás és a látszat problémája mint a megismerés szerves része továbbra is a filozófia középpontjában maradt. (Napjainkban pedig mintha ismét csökkenne a távolság a két megközelítés között. ${ }^{27}$ ) A látszat - amely a létnek a létezőkben mint jelenségekben való, sokszor nem valósághü tükröződésére - mint bölcseleti kifejezés, végigkíséri a filozófia történetét. Felmerül a szubjektív, az objektív (tapasztalati), a logikai, a metafizika-, az esztétikai, a társadalmi és az erkölcsi látszat fogalma. Kant az empirikus (érzéki) látszaton kívül transzcendentális látszatról is beszél, amely abban áll, hogy az ember újra meg újra kísértésbe esik, hogy a kategóriákat és az azokon nyugvó alapelveket a tapasztalat tartományán túl, amelyre egyedül érvényesek, a tapasztalati szempontból transzcendens magánvalóra is alkalmazza. A jelenségek határozmányait átvisszük magára a dologra (Ding an sich), de amit valami lényegeként megragadunk, az valójában csak képzelt lényeg ${ }^{28}$. A látszat az esztétika alapkategóriájának is tekinthető: a müalkotás nem a lényeget ragadja meg, hanem a felszínt, a látszat világát - vagy, mint Heideggernél, a lényegi müvészet éppen az eljövendő igazságot mutatja meg, így még kudarcában is többet mond a létező létéről, mint a tudós. Így a látszatot magában foglaló műalkotás végső soron elvezethet a világláshoz és az elrejtetlenséghez, kitüntetett módja lesz annak, hogy az igazság müködésbe lépjen, létezővé váljon. ${ }^{29}$

A modern természettudományok közben részletesen feltárták és leírták a látás hátterében álló fiziológiai folyamatokat (noha a látvány dekódolása és tárolása kapcsán még nagyon sok kérdőjel maradt), ám ettől függetlenül a megismerés mibenlétét a nyugati gondolkodás Platón óta a látás, megfigyelés metaforája alapján gondolja el. A látás fogalma számos értelmezésben a fiziológiai folyamattól bővebb értelmet nyert, magába foglalva a mentális képalkotás lehetőségét is. (Erre utal pl. az evidencia ${ }^{30}$ vagy az intuícióo ${ }^{31}$ kifejezések

\footnotetext{
${ }^{26}$ Berkeley, George: Értekezés az emberi ismeret alapelveiröl. Gondolat, Budapest, 1985

${ }^{27}$ Lásd pl. azokat a felvetéseket, amelyek az agykutatáshoz mint szellemtudományhoz közelítenek, pl. Valentin Braitenberg nézeteit.

${ }^{28}$ Kant, Immanuel: A tiszta ész kritikája, Atlantisz Könyvkiadó, 2009., 298-301.

${ }^{29}$ Heidegger, Martin: A müalkotás eredete. Európa Könyvkiadó, Budapest, 1988. (Ford.: Bacsó Béla)

${ }^{30}$ Evidentia (latin): beláthatóság. A szót Cicero honosította meg a görög enargeia fordításaként, mint a latin perspicuitas szinonimáját.

${ }^{31}$ A szó szótöve a latin intueri: megnéz, megtekint, megfigyel szóból ered. Mai jelentése a közép-latin intuitio: sugallat, megérzö képesség szóból vezethetö le.
} 
latin eredetije is.) E bővebb értelmezés tükrében a közvetítő a képet a látás során konstruálja, szerkeszti, megalkotja - és nem pusztán konstituálja.

Rudolf Arnheim a gestalt-elméletek ${ }^{32}$ irányából közelítve jelenti ki, hogy a látás távolról sem az érzékszervi észleletek gépies felvétele, hanem ,,a valóság igazán alkotó megragadása, tele fantáziával, invencióval, értelemmel és szépséggel." ${ }^{33}$ Az elme mindig egészként működik, a részletek keltette benyomások összege sosem lesz egyenlő a teljes kép nyújtotta benyomással, hiszen az elme mindig egészként müködik. „Minden észlelés egyszersmind gondolkodás, minden ítéletalkotás egyszersmind intuíció, minden megfigyelés egyszersmind invenció”34 írja 1974-es könyvében az alak és tartalom oszthatatlanságát hirdető művészetpszichológus.

A látás mint témakör a művészettörténet és a mủvészetfilozófia területén is megosztó nézeteket indukált, noha a recepcióesztétikai elméletek nagyobb része a müalkotás mint befogadásra váró látvány felől jut vissza a látáshoz mint tevékenységhez. Konrad Fiedler azonban, aki az autonóm látványszerüség esztétikai követelményeivel foglalkozott, a látás folyamatát tette a művészi kifejezőtevékenység alapjává, a műalkotásokat pedig általánosan kibontakoztatott láthatóságoknak nevezte. Úgy vélte, a szemben olyan erő lakozik, amelyet az csak önmagán túl, a kéz formaadó munkájának mezején bontakoztathat ki. ${ }^{35}$

A hermeneutika és a fenomenológia irányából érkező Gottfried Boehm 1992-es, Látás - Hermeneutikai reflexiók ${ }^{36}$ címü tanulmányában e kérdéseket járja körbe, a látást történeti, szisztematikus, illetve interpretatorikus tekintetben rekonstruálva, méghozzá úgy, hogy az értelmezés feszültségeit nem feltétlenül akarja feloldani. Arra mutat rá, hogy e feszültség (a fogalmak rendje és a látható világba való bepillantás közötti parciális identitászavar) fenntartása és bemutatása olyan megismerési lehetőségeket bontakoztat ki, amelyek egyébként a mítoszokkal és a művészettel egyidősek. Szerinte a szem világa nem feltétlenül egy logoszt alapoz meg, hanem talán különböző logoszokat. Hiszen másképp feloldhatatlan az ellentmondás, a két állítás között: a szem mindig másfajta képet ad a világról, így jogos a látást történeti kontextusban vizsgálni, valamint a szem mint érzékszerv a túlélést szolgája, így szükséges a dolgok objektív, vizuális egyértelmüsége. Felteszi a kérdést: képes-e a szem organikus berendezkedése másfajta képet szolgáltatni a világról, mint a mindig ugyanolyan

\footnotetext{
${ }^{32}$ A gestaltpszichológia (alaklélektan) a német pszichológiában a 20. század elején létrejövő irányzat, melynek alapgondolata, hogy az egész alak észlelete több a részek egyszerü összegénél, és az egész a részekhez képest elsődleges. Föbb képviselöi közé tartozik Max Wertheimer, Wolfgang Köhler, Kurt Koffka és Kurt Lewin.

33 Arnheim, Rudolf: A vizuális élmény. Az alkotó látás pszichológiája. Gondolat, Budapest, 1979.14.

34 U.o.

${ }^{35}$ Fiedler, Konrad: Schriften zur Kunst I. LXVI és XI.

${ }^{36}$ A tanulmány eredeti megjelenése: Boehm, Gottfried: Sehen. Hermeneutische Reflexionen. Internationale Zeitschrift für Philosophie, 1992/1. 50.
} 
„,neutrálist”? Úgy véli, az emlékezés, a tudás, az alakító akarat, a képzelőerő, stb. részvétele a látást nyitott és sokrétűen befolyásolható folyamattá teszi. „S éppen emiatt képes a szem arra, hogy visszaszerezze a tőle olyannyira vitatott megismerőképességet"37 - írja, ugyanakkor felhívja a figyelmet arra, hogy a természettudományos oldal is egyre inkább tevékenységnek tekinti az észlelést, így lassan talán feloldódhat az az ellentét, amely ugyanannak a folyamatnak a természettudományos és történeti magyarázata között feszül. Boehm hajlik arra, hogy a látás determinált, és a szem nem csupán érzékel, hanem maga is létrehoz. Egyfajta programot is megfogalmaz a látás hermeneutikai kritikája számára, amely a szem különleges luciditásának jellemzésére vállalkozva megpróbálhatja leírni a determinációkat és láthatóvá tenni „magát a látható határainak az eltolását”38. Boehm ugyanakkor figyelmeztet: „A szemtörténetek viszonya a történeti folyamathoz oly artikulációt kíván meg, amely a különbségeket és a rokon vonásokat egyaránt pontosítja. Különben a szem régi szolgai szerepét csempésznénk vissza az érzéki tevékenység történetének hátsó ajtaján, s mielőtt még érvényre jutna, ismét elveszne a csak rá jellemző megismerésbeli potenciál." ${ }^{\text {39 }}$

Az itt jelzett kutatási irányokon túl óriási a szakirodalma a látszat mint illúzió illetve funkció problémakörének és a látás mint befogadás témájának úgyszintén. Az ismeretelméleti, recepcióelméleti, esztétikai kutatások teljes és átfogó áttekintése azonban nem lehet célja a jelen munkának. Néhány ilyen elmélet még szóba fog kerülni a következő fejezetek során, egy-egy konkrét, vizualitással kapcsolatos problémához füződően.

A fenti áttekintés után - a már felvetett interdiszciplinaritáshoz is visszacsatolva - meg kell jegyeznünk, hogy az emberi vizuális tapasztalatszerzést sok esetben a többi érzékszervvel való viszonyának rendszerében értelmezik ${ }^{40}$. A vizuális kultúrakutatás tehát nem csak azért nem engedheti meg magának azt, hogy a látást mint olyat elszigetelve vizsgálja, mert akkor például a korunkban meghatározó szerepet betöltő audiovizuális médiával nem tudna mit kezdeni, hanem azért sem, mert magát a látást sem lehet értelmezni a többi érzékszerv közül kiragadva.

$\mathrm{Az}$ itt kiindulópontként felvázolt tapasztalás- és látáselméletek célja nem a maradéktalan áttekintés volt, csupán azon fogalmak kontextusba helyezése, amelyek a

\footnotetext{
37 Boehm, Gottfried: Látás. Hermeneutikai reflexiók. Fordította: Kukla Krisztián. A Nyíregyházi Főiskola adatbázisából. http://nyf.beckground.hu/incoming/filozofia2/3_mi_a_kep/boehm.rtf (letöltés: 2017.09.23.) 5.

${ }^{38}$ U.o. 11.

${ }^{39}$ U.o. 11.

${ }^{40}$ Lásd pl. Molyneux-probléma: a korábban vak ember első látásra felismerné-e a korábban csak tapintott tárgyakat? Több filozófus, köztük John Locke úgy vélte, hogy nem. A MIT újabb kutatásai ezt igazolni látszanak: a korábban vak ember agya nem tudja azonnal összekapcsolni a látottakat a korábban szerzett tapasztalatokkal, ám ezt rendkívül gyorsan meg tudja tanulni.
} 
későbbiek folyamán elötérbe kerülnek majd - e kontextusokhoz azonban szervesen hozzátartozik azon személy pozíciójának megítélése is, aki magába fogadja a látványt.

\section{I.1.3. A szemlélő pozíciójának megvalósulási formái}

Ha a vizuális megismerés lehetőségeit kutatjuk, óhatatlanul szót kell ejtenünk arról a személyről, aki e megismerést végzi, legyen az passzív megfigyelő, vagy aktív befogadó. E pozíciót sokan próbálták felmérni, körülírni vagy épp ebből levezetni a vizuális információfeldolgozás mikéntjeit. ${ }^{41}$

A befogadás problémaköre természetesen túlmutat a képen, számtalan elmélet született azzal kapcsolatban, hogy egyáltalán a müalkotás (legyen az akár a vizuális, akár a verbális) befogadásánál és megértésénél milyen tényezők játszanak szerepet, illetve mennyire érvényesülnek az általános, ember-létből következő megismerési jellegzetességek. Itt meg kell jegyeznünk azt is, hogy a legtöbb, vizualitásra is vonatkoztatható hermeneutikai, recepcióesztétikai elmélet ${ }^{42}$ a képekkel mint müalkotásokkal foglalkozik, ám ezek szolgálhatnak tanulságokkal egy kibővített képfogalomra vonatkoztatva is.

A már említett Gadamer szerint a megértést „,nem annyira a szubjektivitás cselekvéseként, hanem egy hagyománytörténésbe való bekerüléséként kell elgondolni”, ${ }^{43}$ és ő a befogadást újraalkotásként értelmezi. Máté Zsuzsanna rámutat, hogy Gadamer szerint a hermeneutikai szituáció a hatástörténettől és a hatástörténeti tudattól elválaszthatatlan, ily módon a történeti lét egyik módja. Ezáltal az értelmezés, a megértés egyrészt valamilyen hermeneutikai szituáció összefüggésrendszerében müködő konkrét értelemtörténési folyamat, másrészt egy létteremtő folyamat is. Ugyanakkor Máté Zsuzsanna kiemeli a gadameri gondolatok közül a másképpen-értés lehetőségét, azt a lényeges mozzanatot, hogy a megértés során horizont-összeolvadás történik, mely felvázolja a történeti horizontot, s ugyanakkor meg is szünteti. A befogadó kimozdul addigi hatás- és értelem-összefüggéséből, átalakítja és újjászervezi világát, valamint a megértendő is folytonosan másképpen értetté válik e folyamatban, ily módon értelemtörténésként tárul fel. ${ }^{44}$ Így „a megértés nem pusztán

\footnotetext{
${ }^{41}$ Lásd pl. Norman Bryson: Vision and painting. The logic of the gaze. Yale University Press, New Haven, 1983. vagy Hal Foster (szerk.): Vision and Visuality, Bay Press, Seattle, 1988.

${ }^{42}$ Lásd pl. Oskar Bätschmann: Bevezetés a müvészettörténeti hermeneutikába. Corvina, Budapest, 1998.

${ }^{43}$ Gadamer, Hans-Georg: Igazság és módszer. Egy filozófiai hermeneutika vázlata. Gondolat, Budapest, 1984. 87.

${ }^{44}$ Máté Zsuzsanna: Filozofikum és esztétikum kölcsönviszonyáról - kiemelten a madáchi életmüben. Madách Irodalmi Társaság, Szeged, 2018. 37-38.
} 
reprodukáló, hanem mindig alkotó viszonyulás. [...] Elég azt mondani, hogy másképp értünk, amikor egyáltalán megértünk." 45

A gadameri gondolatokkal sok tekintetben rokonságot mutatnak Ernst H. Gombrich meglátásai, amelyeket ugyanabban az évben (1960-ban) publikál ${ }^{46}$, amikor az Igazság és módszer is megjelenik. Gombrich a Müvészet és illúzióban ${ }^{47}$ kifejti, hogy a kép az értelmezés kontextusától függ, azaz a kontextusoktól függően ugyanazt a képet, képrészletet többféleképpen lehet értelmezni. Úgy véli, hogy már az érzéki benyomás is sokféle, így önellentmondás van abban a kijelentésben, hogy ábrázoljuk azt, amit látunk. Ugyanaz a látvány vagy ábrázolás végtelenül sokféle interpretációt tesz lehetővé, és az azt szemlélő feladata, hogy olyan értelmezést találjon, amely összhangban áll korábbi várakozásaival. ${ }^{48}$ Gombrich felhívja a figyelmet arra, hogy érintetlen (romlatlan, elfogulatlan) szem nincs: „, The innocent eye is a myth"49. Ezzel John Ruskin azon felvetését is bírálja, mely szerint a festészet technikai ereje attól függ, szemünk vissza tudja-e nyerni azt, amit egykori romlatlanságának nevezhetnénk, vagyis tudunk-e gyermeki módon látni. ${ }^{50}$ Gombrich úgy véli, hogy az ember mindig antikként, saját múltjától megszállottan közelít saját tevékenységéhez. Az ember szeme nem magában álló, önálló eszközként funkcionál, hanem egy szeszélyes organizmus engedelmes része, és mint ilyen, szelektál, elemez, elutasít, szervez, osztályoz, szerkeszt. ${ }^{51}$ Nelson Goodman erre reflektálva jelenti ki, hogy ,az érintetlen szem és az abszolút adottság mítoszai gonosz cinkosok." ${ }^{52}$ Mindkettő azon gondolatra épül, hogy a megismerés az érzékekből származó nyersanyag feldolgozása, és e nyersanyagot vagy tisztítási szertartásokon vagy módszeres értelmezésmentesítéseken keresztül találjuk meg. „Ámde a befogadás és az értelmezés egymástól el nem választható müveletek” - írja Goodman, hozzátéve: „Kant szava visszhangzik: az érintetlen szem vak, a szüz szellem üres." 53

\footnotetext{
${ }^{45}$ Gadamer, Hans-Georg: Igazság és módszer. Egy filozófiai hermeneutika vázlata. Gondolat, Budapest, 1984. 211

${ }^{46}$ Bár a Müvészet és illúzió felvetéseinek csírái már Gombrich egy korábbi könyvében, a The Story of Art-ban (1950) is felfedezhetök, ahogy erre ő maga is felhívja a figyelmet a Müvészet és illúzió előszavában.

${ }^{47}$ Gombrich, Ernst: Art and Illusion. A Study in the Psychology of Pictorial Representation. Princeton University Press, 1960.

${ }^{48}$ Gombrich, Ernst: Müvészet és illúzió. A képi ábrázolás pszichológiája. (Ford.: Szabó Árpád) Gondolat Kiadó, Budapest, 1972. 350-351.

${ }^{49}$ Gombrich, Erns H.: Art and Illusion, 1960., 270. A kötet magyar fordításban is megjelent Müvészet és illúzió címmel (Gondolat, 1972), ám azért fontos az eredeti mondat, mert pl. Horányi Özséb (A sokarcú kép c. tanulmánykötet bevezetöjében) felveti a kérdést, vajon találó-e az innocent szó érintetlenként való fordítása.

${ }^{50}$ Gombrich, Erns H.: Müvészet és illúzió. Gondolat, Budapest, 1972. 270.

${ }^{51}$ Idézi: Goodman, Nelson: Az újraalkotott valóságról és a képek hangjairól. In: Horányi Özséb (szek.): A sokarcú kép. Typotex, 2003. 44.

${ }^{52}$ Goodman, Nelson: Az újraalkotott valóságról és a képek hangjairól. In: Horányi Özséb (szek.): A sokarcú kép. Typotex, 2003. 44.

${ }^{53}$ U.o. 45.
} 
Gadamer újraalkotással kapcsolatos gondolatainak hatása érezhető többek között Martin Schuster bizonyos, elsősorban müvészetpszichológiai megközelítésű felvetésein is. Schuster úgy véli, a művészeti hatás nem „passzív” szemlélődéssel, hanem aktív „kapcsolatteremtéssel” jön létre. Szerinte „,ha szellemünk révén a formákat és a vonalakat belsőleg lépésről-lépésre újrafestjük, egy kép ritmust, sőt, dallamot sugallhat."54 A műalkotás és nézője közötti kapcsolatok minden esetben akarati döntés következményei. Ennélfogva ugyanaz a mü - a szemléleti beállítódás szerint változó módon - lehet az egyik ember számára közömbös, míg a másikban a tisztelet és a csodálat legmélyebb érzelmeit váltja ki." ${ }^{55}$ - ez utóbbi kijelentése pedig összecseng Gombrich meglátásaival.

Ugyanakkor Gottfried Boehm némiképp szembehelyezkedik a fenti elgondolásokkal. $A$ képi értelem és az érzékszervek ${ }^{56}$ című tanulmányában felhívja a figyelmet arra, hogy a hagyományos értelmezés nem veszi figyelembe az érzékelés dinamikáját. A képet eseményjellegünek tekinti, „mivel a képben lévő lehetséges szemléleti konjunkciók kínálatának csupán olyan látás felelhet meg, amely megszabadult a konstatálás és áttekintés merev funkciójától és képes észlelni a kép dinamikus összefüggéseit.” Boehm a kép érzéki értelmének elvét vallja és kijelenti: „a látás nem fogalmaktól vezérelt megismerésen munkálkodik”. ${ }^{57}$ Szerinte nem újjáteremtés zajlik, hanem a mü bejárása történik, és a látás dinamizmusa bizonyítja, hogy az érzékelés értelmezés is. Egy későbbi tanulmányában ${ }^{58}$ pedig elveti mind annak a lehetôségét, hogy külső adatok, események, hatások láncolatába helyezve lássuk a müalkotást, mind pedig azt, hogy zárt mümonádokként, a kontextust figyelmen kívül hagyva szemléljük őket. Úgy véli, „a tekintet azon iránya tünik döntőnek, amely a műalkotásból indul ki és onnan tekint a történelmi kontextusra, nem fordítva." 59

A kép befogadása kapcsán megkerülhetetlen a Boehm által a fenomenológiai és hermeneutikai tradíciókból elindulva megalkotott ikonikus differencia ${ }^{60}$ fogalma, amely a képet és a rajta kívüli világot választja el és kapcsolja össze egyúttal: „értelmet generál anélkül, hogy azt mondaná, 'van', olyan módon nyit rá a valóságra, hogy az önmagán igazolódik, mutatkozik

\footnotetext{
${ }^{54}$ Schuster, Martin: Müvészetlélektan. Panem Kiadó, Budapest, 2005, 164.

${ }^{55}$ U.o. 165.

${ }^{56}$ Boehm, Gottfried: Bildsinn und Sinnesorgane in. Neue Hefte für Philosophee 18/19., Vandenhoeck/Ruprecht, 1980. 118-132.

${ }^{57}$ Boehm, Gottfried: A képi érzelem és az érzékszervek. (Ford. Poprády Judit) In: Bacsó Béla (szerk.): Kép, fenomén, valóság. Budapest, Kijárat Kiadó, 1997. 252.

${ }^{58}$ Boehm, Gottfried: Werk und Wahrnehmung. In: Ders.: Museum der klassichen Moderne. Insel Verlag Frankfurt am Main und Lipzig, 1997. 11-31.

${ }^{59}$ Boehm, Gottfried: Mü és észlelés. A klasszikus modernség múzeumában. In: Gottfried Boehm: Paul Cézanne: Montagne Sainte-Victoire - Válogatott müvészeti írások. (Szerk.: Bacsó Béla) Kijárat Kiadó, 2005. 117.

${ }^{60}$ Lásd: Boehm, Gottfried: Ikonische Differenz. In: Rheinsprung 11. Zeitschrift für Bildkritik. Basel, 2011. 171.
} 
meg." ${ }^{61}$ Bacsó Béla úgy véli, e differencia annak működtetése, amit végső soron semmi sem fed le, sem a puszta át- és lefordítás, sem pedig a vélt tárgyi hasonlóság azonosítása. ${ }^{62}$ Zámbó Kristóf szerint az ikonikus differencia azon a szemléleti belátáson nyugszik, miszerint a kép befogadása során a megismerő értelem és a megtapasztalt hatás nem feltétlenül kerül egymással teljesen fedésbe, vagyis az előálló képi értelem és a megtapasztalt hatás között valamifajta törés áll fönn. ${ }^{63} \mathrm{Az}$, aminek a képek az ábrázolására törekszenek, valójában ábrázolhatatlan, ám ezt az ábrázolhatatlant nem az ábrázolton túl találjuk, hanem magában a képben. Zámbó szerint a képi értelemképződés nem a szubjektum puszta értelemadási gesztusa: „a képi értelmet nem tartjuk a markunkban, annak genezise az esztétikai tapasztalatban mindig kicsúszik a kezeink közül." 64

A befogadáselméletek különbségeinek ismertetése még hosszasan folytatható lenne, ám a szükebben vett témához való közelítés útján figyelmünket fókuszáljuk a befogadás szubjektumára és annak pozíciójára! Általában e pozíció milyenségétől, aktív vagy passzív voltától függ az, hogy a kép elött álló személyt nézönek (spectator), megfigyelönek (observer) vagy befogadónak (recipient) nevezik-e, esetleg a semlegesebb szemlélö kifejezést használják, bár az elnevezésekben nem feltétlenül alakult ki konszenzus. Mindennek időbeli vonatkozása is van, hiszen sokan változásokat vélnek felfedezni a kép előtt álló szubjektum pozíciójában, és ezeket a változásokat más-más időpontokra teszik, illetve más-más eseményekhez kapcsolják. Boehm például úgy véli, ,a modernség müvészetében benne foglaltatik a megváltozott látás története”, és a XIX. század kezdete óta növekvő vizuális érzékenység figyelhető meg a müvészet fejlődésében. ${ }^{65}$

Az tehát, hogy mikor milyen szerep hárul a kép előtt álló emberre, az korszakonként eltérő lehet. A szemlélő pozíciójának jelentősége - a befogadáselméletek alanyaként való értelmezés mellett - azokból az elméletekből bomlott ki, amelyek a művészet történetét látáskoncepciók egymásra következő rendszereként mutatják be. ${ }^{66}$

\footnotetext{
${ }^{61}$ Boehm, Gottfried: Ikonische Differenz. In: Rheinsprung 11. Zeitschrift für Bildkritik, Eikones, Basel, 2011. Fordította és idézi: Bacsó Béla: Az ikonikus differencia hermeneutikai jelentösége. In: Alföld, 66. évf. 11. szám, 2005. 74.

${ }^{62}$ Bacsó Béla: Az ikonikus differencia hermeneutikai jelentösége. In: Alföld, 66. évf. 11. szám, 2005. 75.

${ }^{63}$ Zámbó Kristóf: Gottfried Boehm és a képi differencia. In: Alföld, 66. évf. 11. szám, 2005. 78-79.

${ }^{64}$ U.o. 83.

${ }^{65}$ Boehm, Gottfried: Mü és észlelés. A klasszikus modernség múzeumában. In: Gottfried Boehm: Paul Cézanne: Montagne Sainte-Victoire - Válogatott müvészeti irások. (Szerk.: Bacsó Béla) Kijárat Kiadó, 2005. 117.

${ }^{66}$ Ezt teszi pl. Heinrich Wölfflin (Kunstgeschichtliche Grundbegriffe: das Problem der Stilentwickelung in der neueren Kunst. Bruckmann, München 1915), de Georg Simmel is többek között az alkotás másféle, immanens létmódja felől közelítve emeli ki Rembrandtot a képzőmüvészek sorából (Rembrandt. Ein kunstphilosophischer Versuch, 1916)
} 
A XVIII. század közepéig a képek értelmezése elsősorban azok ikonografikus, mindenki számára azonos módon történő olvasását jelentette. Oskar Bätschmann szerint a kép egyéni értelmezése elhanyagolható volt, s ez olyan helyzetet teremtett, mint ha a néző nem is létezett volna! ${ }^{67}$ Később, az ikonológia megjelenésével (e folyamatról később részletesen is szót ejtünk) egyre inkább előtérbe került a befogadás szubjektív lehetősége is. Földényi F. László szemlélteti ezt a változást: „A műalkotás egyre inkább az őt befogadó nézőnek lesz kiszolgáltatva: ennek egyéni látásmódjától függ, hogy megelevenedik-e, illetve a lelkiállapotától, kellő lelkesültségétől, hogy mennyire válik teljessé." ${ }^{68}$ A befogadónak a műben való maradéktalan feloldódása paradox módon ahhoz vezetett, hogy a műalkotásnak ismét egy hozzá képest külsődleges horizonthoz kellett igazodnia: a befogadói készenléthez. Ebből következően Földényi szerint a mű a XVIII. század végétől bizonyos értelemben véve befejezhetetlenné válik, hiszen minden tekintet újraalkotja azt, de egyik sem érvényteleníti a másikat, ezért az értelmezési lehetőségek száma végtelen marad. ${ }^{69}$

Ám túlságosan leegyszerüsítő lenne az a szemlélet, ha csupán XVIII. század előtti és utáni nézőről beszélnénk. Feltételezhető, hogy a történelem több pontján is bekövetkeztek olyan változások, amelyek radikálisan mássá tették a befogadó státusát. Arthur C. Danto 1989-es, Történetek a müvészet végéről ${ }^{70}$ címü tanulmányában több ún. externális küszöböt állít fel, amelyek a hatásban érhetők tetten, és mindig egy újfajta nézőpont megképződésében manifesztálódnak. Érdemes ezeket figyelembe venni ahhoz, hogy megértsük a képfogyasztó jelenlegi pozíciójának sajátosságait, a táguló vizuális portfóliók közegének kialakulását.

Az első ilyen küszöb 1300 környékén következik be, és Giotto, majd Piero Della Francesca freskóin érhető tetten: a reneszánsz feltalálja a perspektíva illúzióját, mely az abszolutizált szem számára adatik meg. Minden egy idealizált nézőpontból van megfestve, amely nézőpontot testi valóságunkkal sosem foglalhatjuk el. A reneszánsz müvész egy mágikus ablak ura. „Az ablakon áthatoló tekintet az, amire korlátozva vagyunk: így redukál a varázserő testetlen szemekké, puszta megfigyelőkké minket."71 A második küszöb száz évvel később, Caravaggio festményein látható: a barokk kiterjeszti az illúziót a néző testi jelenvalóságára is, így kívül kerül azon a tradíción, ami a reneszánszra jellemzö. A testetlen szem itt újra testet ölt, már nem a vizuális, hanem a spirituális illúzió az, ami magával ragad. Ám Danto figyelmeztet,

\footnotetext{
${ }^{67}$ Bätschmann, Oskar: Pygmalion als Betrachter. Die Rezeption von Plastik und Malerei in der zweiten Hälfte des 18. Jahrhunderts. In: Kemp, Wolfgang (szerk.): Der Betrachter ist im Bild. Reimer, Berlin, 1992. 240.

${ }^{68}$ Földényi F. László: Képek elött állni. Kalligram, Pozsony, 2010. 180.

${ }^{69}$ U.o. 181.

${ }^{70}$ Danto, Arthur C.: Történetek a müvészet végéröl. In: Perneczky Géza (szerk.): A müvészet vége? Európai füzetek, 1. szám, Új Világ Kiadó, 1995. 77.

${ }^{71}$ U.o. 75.
} 
hogy abszurd dolog lenne megkívánni, hogy a korábbi ember ismerős realitásként élje meg az újfajta illúziót, a merőben más élményt. Az új periódus nem az előzőből fejlődik ki, és nem füzi ehhez fejlődéstörténeti szükségszerüség. A művészet vége, illetve a művészet történetén belül jelentkező egy bizonyos elbeszélés-struktúra vége mindig az intern történetre vonatkozik! ${ }^{72}$

Danto a fentiekhez hasonló externális különbséget talál a 19. században fellépő, a modern festészet felé vezető új irányzatok megjelenésében is. A fotó és film felfedezésével az illúziókeltés képessége kisiklik a képzőművészek kezéből. És végül, Andy Warhol „szobrai”, a Brillo-dobozok (1964) ${ }^{73}$ jelentik Danto számára a filozófiai kérdésfeltevés megtestesülését: miért számít valami művészetnek, ha egy másik, pontosan úgy kinéző dolog nem művészet? Itt a képzőművészet beleolvadni látszik a lényegét firtató esztétikai és filozófiai kérdésekbe. ${ }^{74}$ (Hasonló gondolatot vet fel Danto egy másik müvében ${ }^{75}$, Duchamp Fountain-je kapcsán is.)

Sokan, köztük Gottfried Boehm a francia impresszionizmushoz és a fotográfia ezzel párhuzamos fejlődéséhez (is) kötnek egy váltást, amely a szemlélő pozícióját érinti. Boehm szerint a kamera „egy új vizuális figyelem gépezete”76, amely által a látás addig ismeretlen hitelességre tett szert: „a látásban és annak megismerő-képességében bízni lehet.” Ezt a biztonságérzetet erősítette az a tény, hogy a kamera képes volt becsapni a szemet, így „világossá váltak a szem teljesítőképességének határai, és hogy miként lehet túljutni azokon."77

Jonathan Crary A megfigyelö módszerei. Látás és modernitás a 19. században címü 1990-ben megjelent tanulmányában ${ }^{78}$ a látás történeti konstrukcióját járja körbe, azt vizsgálja, hogy a 19. század elején elindult folyamatok hogyan definiálták újra a megfigyelő státusát. Koncepciója szembe megy a közismert látáselmélet-fejlődéstörténetekkel, a reneszánsszal beköszöntött fordulathoz hasonló, következő nagy váltást ő más, korábbi időpontra teszi. Kísérletet tesz arra, hogy a művészettörténet mesternarratívájából kibontsa a nézői szálat. Ahogy W.J.T. Mitchell rámutat: Crary a hagyományos művészettörténettel szemben kritikus pozícióba helyezkedik, amikor ragaszkodik a néző modelljeit központi helyen számontartó vizuális kultúra szélesebb körü bírálatának fontosságához. A pszichológia, a filozófia, az

\footnotetext{
72 U.o. 76.

${ }^{73}$ A szappanos súrolópárnák csomagolására szolgáló Brillo dobozok Andy Warhol Grocery Store-sorozatának részei voltak a Heinz ketchuppal és a Campbell leveseskonzervekkel együtt.

${ }^{74}$ Danto, Arthur C.: Történetek a müvészet végéröl. In: Perneczky Géza (szerk.): A művészet vége? Európai füzetek, 1. szám, Új Világ Kiadó, 1995. 80.

${ }^{75}$ Danto, Arthur C.: Hogyan semmizte ki a filozófia a müvészetet? (Ford.: Babarczy Eszter) Budapest, Atlantisz, 1997. 29.

${ }^{76}$ Boehm, Gottfried: Mü és észlelés. A klasszikus modernség múzeumában. In: Gottfried Boehm: Paul Cézanne: Montagne Sainte-Victoire - Válogatott müvészeti írások. (Szerk.: Bacsó Béla) Kijárat Kiadó, 2005. 118.

77 U.o.

${ }^{78}$ Crary, Jonathan: Techniques of the Observer: On Vision and Modernity in the 19th Century. MIT Press, 1990.
} 
ikonológia és a művészettörténet szempontjainak összekapcsolásával új szintézist hoz, átfogó koncepciót szeretne nyújtani. ${ }^{79}$

Crary felteszi a kérdést: Mikor következett be a szubjektivitást hozó fordulat a látásban? Azt célozza meg, hogy egyszer s mindenkorra rácáfoljon arra az általánosan elterjedt nézetre, mely szerint: „Manet-val, az impresszionalizmussal és/vagy posztimpresszionalizmussal a vizuális reprezentáció és észlelés új modellje jelenik meg, amely szakítást jelent a látás másik, több évszázados, közelítőleg reneszánszként, perspektivikusként vagy normatívként meghatározható modelljével" 80 Ö tehát szembe helyezkedik azzal az állásponttal, miszerint az impresszionisták vették először észre a megfigyelő adalékát, ők konstruálják meg azt a szubjektivitást, amely a modern mủvészet és ismeretelmélet egyik legfőbb jellemzője. Crary szerint a modern szubjektum megszületése jóval korábban végbement, a látás jelenben zajló absztrakciójának meghatározó előfeltételei a 19. század elején alakultak ki. A modernista festészet, a fényképezés, a mozi (születése: 1895) okozta lázat egy 1820-ban már javában zajló rendszerváltás későbbi tüneteinek tekinti. Szerinte a kortárs gondolkodók (köztük pl. Nietzsche) fel is ismerték, hogy az alapvető fordulat a 19. század elején következett be, ám a művészettörténészek későbbi nemzedékeinek munkája elhomályosította ezt.

Crary szerint a camera obscura a XVII.-XVIII. századi látás analógiája: a sötét dobozon vágott apró nyílás, amely a külső világról fordított és kicsinyített képet ad, nagyon közel állt a passzív, pusztán a látványt befogadó szubjektum képéhez. Szétválasztja a látás aktusát és a megfigyelő fizikai testét, hiszen tudjuk, hogy amit látunk, az a valóságban fordítva van. Ugyanakkor: a camera obscura végrehajtja az individualizáció mủvészetét, szükségszerüen egy elszigetelt, sötét, keretei közé bezárt és független megfigyelőt határoz meg. Egyfajta aszkézisre, a világtól való visszavonulásra ösztökél, hogy ezen keresztül az ember a most már külső világ tartalmaihoz való viszonyát szabályozhassa és megtisztíthassa. Elválaszthatatlan a befelé fordulás sajátos metafizikájától: egyaránt metaforája a megfigyelőnek, aki névlegesen szabad, szuverén egyén, és egy privatizált szubjektumnak, aki be van szorítva egy, a nyilvános világtól leválasztott térbe. A camera obscura hitelesíti és törvényesíti az egyén nézőpontját, de a megfigyelő fizikai és érzékleti élményét kiszorítják a mechanikai szerkezet és az objektív igazság előre adott világa közötti viszonyok. Az 1900-as évek elején azonban egy új fajta néző öltött alakot Európában! A korábbi néző testetlen volt, vizuális élménye a camera obscura test

\footnotetext{
${ }^{79}$ Mitchell, W.J.T.: A képi fordulat. In: Szőnyi György Endre, Szauter Dóra: A képek politikája. W.J.T. Mitchell válogatott írásai. Jate Press, Szeged, 2012. 142.

${ }^{80}$ Crary, Jonathan: A megfigyelö módszerei. Látás és modernitás a 19. században. Osiris Kiadó, Budapest, 1999. 16.
} 
nélküli viszonylatai szerint modelleződött. Ez a néző a XIX. században „testet ölt”, és a szemlélődő néző lehetősége ezzel romba dől. A modernitás tehát egybeesik a látás klasszikus modelljeinek és reprezentációik stabil terének összeomlásával. A látás felszabadul, elpártol azoktól a merev struktúráktól, amelyek a tárgyait alakították és alkották.

Crary szándékosan használja a megfigyelö (observer) kifejezést a nézö (spectator) helyett. A megfigyelő nem csak valaki, aki lát, hanem olyasvalaki, aki a lehetőségek elöre meghatározott halmazán belül van kitéve az impulzusoknak, konvenciók és korlátozások rendszerébe ágyazva. Crary úgy véli, a megfigyelö újrapozicionálása egy körülhatárolhatatlan terepen veszi kezdetét, ahol a belső érzékelés és a külső jel közötti megkülönböztetés visszavonhatatlanul elmosódott: „Az emberi szem legtöbb történelmileg lényeges funkcióját olyan gyakorlatok váltják fel, amelyekben a vizuális képeknek már nincs utalásuk a megfigyelő valós, optikailag észlelt világban elfoglalt helyzetére. (...) A vizualitás egyre inkább kibernetikus és elektromágneses terepre helyeződik át, ahol az absztrakt vizuális és nyelvi elemek egybeesnek, és ahol ezeket globálisan fogyasztják, forgalmazzák, cserélik." 81 A vizuális kultúrában bekövetkezett fordulat túlmutat a maga területén, és egybecseng azzal a gondolkodásbeli fordulattal, amelyet a XIX. század elejének gondolkodói definiáltak önmagukon és elöre jeleztek. A látás elméletében beköszöntött fordulat „,forradalmárait” Crary nem a művészek, hanem a tudósok körében véli megtalálni. (Hivatkozik Descartes-ra, Lockera és Hume-ra, Schopenhauer-re, Nietzschére, de Deleuze, Baudrillard, Marx, Foucault, Lukács György reflexióit is idézi.) A látáskultúra (látszólag XX. századi) átalakulása mögött világképváltás bújik meg, és ennek figyelembevétele nélkül, pusztán technokrata megközelítéssel nem lehet a látás történetét taglalni.

Baudrillard 1981-ben a televízió és a reality-müsorok ${ }^{82}$ kapcsán veti fel egy újabb fordulat lehetőségét. „A tévé szeme többé nem abszolút tekintet forrása” - írja, hozzátéve, hogy „,többé nem kötelező engedelmeskedni a modellnek vagy a tekintetnek." ${ }^{\text {"3 }}$ Attól kezdve, hogy nem csak az ember nézi a televíziót, de a tévé is az embert, minden képlékennyé válik, összekeveredik: „nincs többé tárgy, fókuszpont, centrum vagy periféria: csak körkörös elhajlás és elhajlítás." ${ }^{" 84}$ Ezáltal Baudrillard szerint lassan bezáródunk a szimulákrumba, ahol már eltűnt a szimulált dolog és a szimuláció közötti különbség. Míg az ábrázolás a jel és a valóságos dolog

\footnotetext{
${ }^{81}$ Crary, Jonathan: A megfigyelö módszerei. Látás és modernitás a 19. században. Osiris Kiadó, Budapest, 1999. 14.

${ }^{82}$ Baudrillard a Loud-családot nyomon követő, An American Family címü, Craig Gilbert ötlete nyomán forgatott reality-sorozatra utal, melyet 1973-ban mutatott be a PBS tévécsatorna. Ezt tekinthetjük az első valóságshow-nak. ${ }^{83}$ Baudrillard, Jean: A szimulákrum elsőbbsége. (Ford.: Gángó Gábor) In: Kiss Attila, Kovács Sándor, Odorics Ferenc (szerk.): Testes könyv I., Dekon könyvek, Ictus / JATE Irodalomelmélet Csoport, Szeged, 1996. 183. ${ }^{84}$ U.o.
} 
közötti ekvivalencia elvéből indul ki, addig a szimuláció a jel mint érték radikális tagadásából. Míg az ábrázolás megpróbálja feloldani a szimulációt, melyet hamis ábrázolásnak értelmez, addig a szimuláció magába zárja mint szimulákrumot, az ábrázolás egész építményét.

Felmerül a kérdés, hogy a XXI. század elejének folyamatai, a digitális kép elterjedése, a kép ezáltali testetlenné és befejezhetetlenné válása, a képek mennyiségi növekedése és azok kommunikációra való, minden korábbinál aktívabb felhasználása, illetve a képen való állandó szereplés- valamint az önportrékészítés lázas igénye hozhatott-e egy újabb nézői pozícióváltást, vagy szemlélt és a szemlélö viszonya tovább bomlik? A baudrillard-i szimulákrumban élünk? A befogadói szerepkörre minden bizonnyal hatást gyakorol az a tény, hogy a kép nyújtotta látvány értelmezési mozzanatával szemben egyfajta képfogyasztói attitűd vált dominánssá. $\mathrm{Az}$ ennek megragadásához szükséges tünetek számbavétele azonban majd a II. fejezet feladata lesz. Elötte viszont elengedhetetlen megvizsgálni a kép fogalmával kapcsolatos polémiákat.

\section{I.2. Dilemmák a képek ontológiai státuszának és hovatartozásának meghatározása körül}

„Csak amióta a képeknek nincs helyük, azóta tudjuk ismét, hogy a képek nem csupán képek, de hely is kell nekik." 85

Hans-Georg Gadamer

Mi a kép? Ez a kérdés a XX. század végén új megközelítésben kerül előtérbe, és talán fontosabbá válik azoknál a dilemmáknál is, hogy miben áll a látás, hogyan történik a reprezentáció. Már maga a kérdés megfogalmazása is a kép autonóm létére való fókuszálásra utal: nem a képet létrehozó vagy az azt látó személy felől közelítjük meg a problémát, hanem a látás és a reprezentáció tárgya felől. Sőt, a kérdésfeltevésben az ok-okozati viszony megfordíthatósága is benne rejlik: nem csupán az a lényeges, hogy az ember hogyan alakítja a képet, de annak vizsgálatára is alkalmat ad, hogy a kép hogyan alakítja az embert - vagy éppen a társadalmat.

A kérdésre adott válaszok természetesen sokfélék, ahogy maguk a képek is azok. Felfoghatók tárgyként, aktusként és konstitúcióként, ${ }^{86}$ de akár nyelvként is. Egységesen definiálható képfogalom tehát aligha adható, érdemes azonban megkísérelni valamiféle

\footnotetext{
${ }^{85}$ Gadamer, Hans-Georg: Igazság és módszer. Egy filozófiai hermeneutika vázlata. (Fordította: Bonyhai Gábor) Gondolat Könyvkiadó, Budapest, 1984. 108.

${ }^{86}$ V.ö.: Horányi Özséb: Bevezetés. In: Horányi Özséb (szerk.): A sokarcú kép. Válogatott tanulmányok a képek logikájáról. 2. módosított kiadás. Typotex, Budapest, 2003.
} 
csoportosítást közöttük, már csak azért is, hogy a képekről szóló fejtegetésekben lehetővé váljon a szükített értelmezések használata. A képek ontológiai státusának vizsgálata során tehát további kérdésként fel fog merülni, hogy milyen képek vannak, és hová tartoznak?

Danto, Belting, Boehm és Mitchell meglátásai nyomán élénk vita bontakozott ki azzal kapcsolatban , hogy a képek elemzésére és a képekkel kapcsolatos jelenségek vizsgálatára mely tudományágak alkalmasak, illetve van-e esély egy átfogó, interdiszciplináris megközelítésű képtudomány kialakítására. Az említett gondolkodók legjelentősebb publikációinak idején már jól látszott: egyre nő azoknak a képeknek a száma, amelyek nem férnek be a müvészettörténet illetékességi területére, ám a hagyományos diszciplínákhoz viszonyítva még fiatalnak számító kommunikációtudomány illetve médiatudomány is csak bizonyos aspektusokból vizsgálja őket. Mindezt már Gadamer is elörevetítette fent idézett, igen találó megfogalmazásában. Hol van tehát a képek helye? Ezen alfejezet e dilemmák aspektusait vizsgálja.

\section{I.2.1. A képek mibenléte és csoportosításuk nehézségei}

A látás fogalmának értelmezésével szorosan egybefonódik a kép fogalmának definiálása. A legáltalánosabb és legegyszerübb megfogalmazás értelmében képeknek kell tekintenünk az olyan információforrásokat, amelyek a látvány logikájával közelíthetők meg. Ám sok olyan dolgot is képnek nevezünk, amelyre ez a kitétel igaz is meg nem is. Hiszen beszélünk például költői képekről, amelyek nem a vizualitásban, hanem a verbalitásban gyökereznek, mégis könnyed természetességgel nevezzük őket képeknek, hiszen végső soron mégiscsak valamiféle látványt képeznek meg az elménkben, mondhatnánk úgy is: a lelki szemeink előtt. E kifejezés is jelzi, hogy az ember valahol mindig a látáshoz, a látványhoz, a képiséghez kötötte a „belső”, szakszerübben megnevezve: a mentális képek konstruálását is. A hindu és a buddhista irodalomban, a teozófiában megjelenik a harmadik szem, vagy más néven a belsö szem/láthatatlan szem fogalma, amely a nem fiziológiai érzékelésért felelös, ugyanakkor élesebben láthatja a valóságot és az igazságot azok számára, akik használni tudják. (És itt visszautalhatunk a tapasztalat fogalmának körbejárásánál korábban felvázolt filozófiai problémára, amely az érzéki megismerést állítja szembe a belső, mentális vagy bölcselet útján szerzett tapasztalattal.)

A kép (ikon, imago, image) a latin „imago” (képmás, szobor), illetve az ,imitari” (utánozni) szóból származik. A kép szót nagyon sok mindenre használjuk, ezért komoly nehézségekbe ütközünk, ha pontosan akarjuk definiálni, vagy csak valamiféle rendszert szeretnénk felállítani a különböző típusú képek között. Hiszen egyaránt képnek nevezünk egy 
festményt és egy álomképet, egy tükröződést és egy emlékképet, egy szemünk elé táruló kilátást és egy térképet, egy csupán digitális jelként létező fotót és egy tankönyvi ábrát, stb. Meg kell jegyeznünk, hogy az angol nyelvben két kifejezés használatos: a „picture” inkább mint fizikai hordozón megjelenő, vagy technikai kép, ábra, az ,,image” pedig mint mentális kép, vagy mint ábrázolás, megtestesítés, szimbolizálás, visszatükrözés, képzet használatos. A német nyelvben azonban nincs ilyen megkülönböztetés, a német szakirodalom a , das Bild”' kifejezést használja. (Talán ez is okozza azt a szemléletbeli eltérést, amely a XX-XXI. század fordulóján, az amerikai/globális és a német/európai, fenomenológiai-hermeneutikai tradíciókból táplálkozó képkutatás, a pictorial turn és az ikonische wende között érzékelhető, és amelyre később még kitérünk.)

A kép fogalmának értelmezése kapcsán óhatatlanul eljutunk a képzet és a képződmény fogalmaihoz. A forma, az alak, a szimbólum, a jel Szent Ágoston és a középkor platonizáló képfilozófiájában is fontos szerepet tölt be. A skolasztikusok pedig megkülönböztették a repraesentatio-t, azaz a képzetet mint szándékolt ábrázolást, illetve a phantasma-t, amely érzéki adatok megjelenítésében áll, nem a közvetlen hatást gyakorló érzéki ingerek, hanem a korábbi észlelések következtében fennmaradt nyomok alapján. A periférikusan kiváltott észleléssel, valamint az azt követő utóképpel ellentétben a képzet központilag létezik. „Amikor az ember egy formátlan tömeget kialakít és megformál, akkor képződmény keletkezik. Amennyiben ez a képződmény valami másra utal, mert egyezik vele forma és alak szerint, és ily módon ez a valami mást jelenvalóvá teszi, megjeleníti a szemlélő számára, úgy a képződmény a szóban forgó valaminek a képe.” - olvashatjuk a Brugger-féle Filozófiai lexikonban. ${ }^{87}$ Beszélhetünk ösképről, ha a kép eredendően tartalmazza a mértékadó formát. Ha pedig a leképezett azonosságot mutat az ösképpel, akkor képmásnak nevezzük.

Gadamer Igazság és módszer címü hermeneutikai vázlatában külön kitér a képekre, egészen pontosan a kép létrangjára. ${ }^{88}$ Rámutat, hogy a kép „,közvetlenül” tapasztalható, tehát nem szorul közvetítésre és látszólag igazolja az esztétikai tudat - amellyel Gadamer a hermeneutikai tapasztalatot állítja szembe - közvetlenségét. Ő azonban mégis arra bíztat, hogy próbáljuk a képet elválasztani az esztétikai tudattól és attól a képfogalomtól, amelyhez a modern galéria hozzászoktatott minket, és próbáljuk összekapcsolni a dekoratív fogalmával, amit az élményesztétika lejáratott. Gadamer ezután két létmódot tár elénk. Az egyikben a képben bemutatás valami mintaképére vonatkozik (=kép), a másik pedig a leképezés viszonya, a

\footnotetext{
${ }^{87}$ Brugger, Walter: Filozófiai lexikon. Szent István Társulat, Budapest, 2005., 241.

${ }^{88}$ Gadamer, Hans-Georg: Igazság és módszer - Egy filozófiai hermeneutika vázlata. Gondolat Könyvkiadó, Budapest, 1984. 107.
} 
képmás mintaképre való vonatkozása (=képmás). Az utóbbi a leképezett közvetítését szolgálja, esetében a képmásban felismerjük a mintaképet. Magáért való léte megszünik, mert eszközként funkcionál. (Az igazolványképnek például Gadamer szerint eszköz-léte van.) Az előző esetében azonban a kép nem utasít bennünket egyszerüen tovább a megmutatotthoz, bár lényegi összefüggésben marad vele. A kép saját létét érvényesíti, léte a megmutatkozásban áll. „Még a mai mechanikus technikák is alkalmazhatók müvészileg, amennyiben a leképezettből valami olyasmit hoznak ki, ami annak puszta látványában mint látványban így nem is volt benne. Az ilyen kép nem képmás, mert valami olyasmit ábrázol, ami a kép nélkül így nem mutatkozna

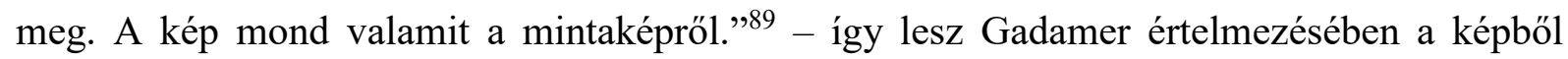
autonóm valóság az egyoldalú vonatkozás helyett.

Számos olyan megfogalmazással találkozunk a lexikonokban és enciklopédiákban, amely a kép fogalmához az egyezés, a valósághoz való hasonlatosság, a megmutatás, visszaadás felől közelít. Ennek oka bizonyára az, hogy a kép szót hallva elsőként a művészeti alkotás jut eszünkbe. Gombrich azonban több írásában tiltakozik azon megfogalmazás ellen, amely - ahogy egy tanulmányában ${ }^{90}$ kikel ellene - „befészkelte magát” még az Oxford szótárba is: a reprezentáció hagyományos felfogása értelmében a müvész utánozza az előtte lévő tárgy külső formáját, a szemlélő pedig a formája alapján ismeri fel a műalkotás témáját. Gombrich nem ad egyértelmü definíciót a kép fogalmára, életműve mégis igen nagy hatással volt az utókor képkutatóira, hiszen újszerüen gondolkodott a képek céljáról, jelentéséről, a képekben rejlő információ minőségéről, kép és szó viszonyáról, illetve arról, hogy mik a kép lehetőségei a kommunikációban.

Sokan gondolkodtak úgy, hogy a képekhez való közelítés egyik alapvető feltétele lenne, hogy rendet rakjunk azon sok összetevő között, amelyet e fogalom alá besorolunk. Többnyire három nagyobb csoportot szokás megkülönböztetni. Az egyik csoportba a biológiai, élettani természetü, észleleti képeket sorolják. Antik Sándor szerint ezek lehetnek egy biológiai lény által recepcionált alak- és színérzetképek, a biológiailag determinált retinális kép, és ennek biológiailag kódolt változatai. ${ }^{91}$ A másik nagyobb csoportot a mentális természetü képek teszik ki, ide tartoznak az emlékként felidézett képek, az álmok, a fantáziák, de sokan ide sorolják a verbális közlés szóképeit is, amelyek elménkben bontakoznak ki. Nyíri Kristóf e mentális

\footnotetext{
${ }^{89}$ Gadamer, Hans-Georg: Igazság és módszer - Egy filozófiai hermeneutika vázlata. Gondolat Könyvkiadó, Budapest, 1984. 110.

${ }^{90}$ Gombrich, E.H.: Meditations on a Hobby Horse or the Roots of Artistic Form. In: L.L. Whyte (szerk.): Aspect of Form. Indiana University Press. Bloomington, 1951., 209.

${ }_{91}$ Antik Sándor: Vizuális megismerés és kommunikáció. Egyetemi Műhely Kiadó, Bolyai Társaság, Kolozsvár, 2010., 10 .
} 
képeket dinamikus természetünek tartja, és úgy véli, inkább a mozgóképhez lehet őket hasonlítani. ${ }^{92}$ A harmadik csoport pedig a fizikai természetü képeké, amelyek keletkezhetnek a fényjelenségek által spontán (árnykép, tükröződés) vagy tudatos emberi közremüködés révén (camera obscura, dagerrotípia, fénykép), de ide tartoznak az emberi kéz által létrehozott ábrázolások is a lapszéli firkáktól a müalkotásokig. Ezeken belül különböztethetjük meg a technikai képeket, melyek emberi közremüködést igényelnek, és e csoportba nem értjük bele a spontán fizikai jelenségek által létrehozott képeket. A technikai kép fogalma megközelíthető a hordozó felől, hiszen ezeket tudatosan hozza létre az ember manuálisan vagy valamilyen berendezés, eszköz által vászonra, papírra, kőre stb., vagy digitális jelként egy képernyőre. (De megfontolandó, hogy Hans Belting szerint a régi, forma és tartalom szerinti megkülönböztetés ma már nem célravezető, nem lehet a képet szétválasztani a hordozójától. Az anyagiság mint terminus egyébként sem felelne meg a mai médiumok jellemzésére. A médium lehet maga a forma, de olyan eset is van, amikor a médium közvetíti a formát!93 A közvetített képek medialitása tehát igen összetett probléma, amelyre később még kitérünk.) Az sem ritka, hogy a technikai kép megnevezéssel egészen egyszerüen a gépi közremüködéssel készült képeket illetik $^{94}$. Az apparátus által előállított kép mibenlétére, tulajdonságaira és a fotó fogalmára azonban a következő fejezetben térek ki bővebben.

Horányi Özséb a képfilozófiákat és látásfilozófiákat összegezve rámutat, hogy manapság létezik egyfajta konszenzus abban, hogy a kép valamiféle tudás (kánon, nyelv, kód, szkéma, szabály) fényében válik képpé, tehát a kép képvolta nem valamiféle „inherens” tulajdonság, hanem konstitúció eredménye. Ám nincs konszenzus abban, hogy mit is konstituál a kánon, vagyis abban a kérdésben, amely tradicionálisan a kép ontológiai státuszát (státuszait) keresi ${ }^{95}$ Horányi egy térképen ábrázolja a képekre vonatkozó elméleti megközelítések föbb vonatkozásait. ${ }^{96}$ Erről leolvasható, hogy a szakemberek különféle perspektívákból (történeti, filozófiai, pszichológiai, művészeti, szociológiai perspektíva, illetve a konceptuális-analízis perspektívája) közelítenek a képhez. A másik rendező elv a képelméleti konceptusokból

\footnotetext{
${ }^{92}$ Nyíri Kristóf: A gondolkodás képelmélete. In: Neumer Katalin (szerk.): Kép, beszéd, irás. Gondolat, 2003. 266. Illetve: Nyíri Kristóf: Kép és idő. Magyar Mercurius, Budapest, 2011. 168.

${ }^{93}$ Belting, Hans: Image, Medium, Body: A New Approach to Iconology, Critical Inquiry. Volume 31., Winter, 2005, 302-319.

94 Ezzel a szóhasználattal - „technischen Bilder” - él Vilém Flusser Für Eine Philosophie der Fotografie címü munkájában. (Göttingen, 1983.)

95 Horányi Özséb: Bevezetés. In: Horányi Özséb (szerk.): A sokarcú kép. Válogatott tanulmányok a képek logikájáról. 2. módosított kiadás. Typotex, Budapest, 2003. 13.

${ }^{96}$ Hangsúlyozza, hogy ennek célja csupán az általa szerkesztett kötet tanulmányainak könnyebb áttekinthetősége! Ám ennek ellenére hatalmas segítséget nyújt ahhoz, ha át akarjuk tekinteni a területen zajló diskurzust.
} 
tevődik össze. Vannak kutatók, akik a képet mint tárgyat, mások a képet mint aktust vizsgálják, a harmadik megközelítés pedig a kép mint konstitúció!

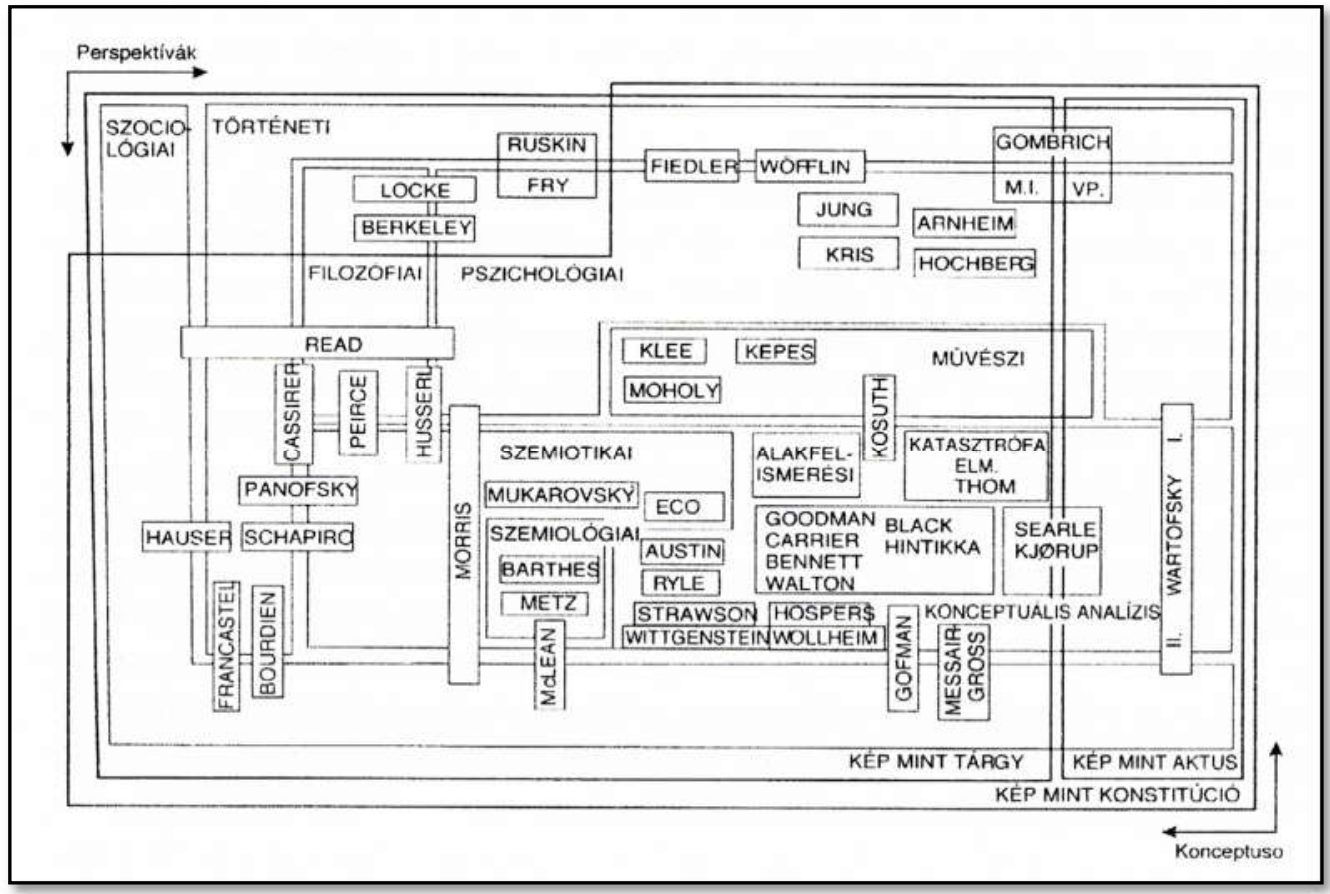

Horányi Özséb térképe a képekkel kapcsolatos tanulmányok áttekintésére. Forrás: Horányi Özséb (szerk.): A sokarcú kép. Válogatott tanulmányok a képek logikájáról. 2. módosított kiadás. Typotex, Budapest, 2003. 16. old.

Ha a képet csupán mint müalkotást tekintjük, és a müvészettörténet területén belül maradva vizsgáljuk meg, akkor is definiálási nehézségekbe ütközünk. Hiszen bizonyos értelemben a szobor, a dombormü, sőt, az építészeti alkotás is kép, nem csupán a táblakép, amit a köznyelv képnek nevez - bár Theodor Hetzer a „képfelség” elvének ${ }^{97}$ kibontásakor arra mutat rá, hogy csak az európai festészet virágkorától, a reneszánsztól vannak olyan képek, amelyek önmagukban is megállnak, keret és környezet nélkül is egységes, zárt képződményt alkotnak. Felvetődik tehát a kérdés, hogy hol van a kép határa? Mi minden tartozik hozzá? Lehet-e egyáltalán képről mint olyanról beszélni, kiragadva azt a környezetéből? Inkább az lehet a helyes elgondolás, hogy a képeket az időbe és térbe ágyazottan vizsgáljuk meg, mindig odafigyelve a megfigyelővel, befogadóval való viszonyára is?

Arra is látunk példát, hogy a müvészettörténészek kilépnek a képfogalom szükre szabott értelmezési keretéből. Aby Warburg például nem fogalmaz meg konkrét képelméletet, látásmódja azonban nagyon sokakra hatással volt. Rényi András Warburg argumentációját vizsgálva $^{98}$ arra jut, hogy a neves müvészettörténész képfogalma túlmutat a

\footnotetext{
${ }^{97}$ Hetzer, Theodor: Dürers Bildhoheit. V. Klostermann, 1939.

${ }^{98}$ Rényi András: Aby Warburg Rembrandtról: adalékok a performatív kép antropológiájához és a müvészettörténet recepcióesztétikai megújításához.
} 
müvészettörténészek bevett szóhasználatán: a képet nem festett-faragott objektumként, hanem a tapasztalati világ megmutatkozásának médiumaként, világ-viszonyként kezeli.

A képek mibenlétével kapcsolatos nézetek folyamatosan változnak a kommunikációtörténeti mérföldkövek fényében, illetve azáltal, hogy az embert körülvevő képek is változnak. Søren Kjørup dán filozófus rámutat, hogy a valóban hatékony sokszorosítási eljárások hiányában a legutóbbi időkig ki sem fejlődhettek, el sem terjedhettek, nem legitimálódhattak a képhasználatnak azok a módjai, amelyek a legprimitívebbeknél összetettebb társadalmi funkciókat képesek megvalósítani. Horányi pedig arra figyelmeztet: a kép-konstitúció manapság a művészet mint intézmény kereteit feszíti szét, vagy legalábbis állandó „definíciós bizonytalanságot” idéz elő: művészet-e az, avagy nem művészet, ami a konstitúció eredményeként létrejön? ${ }^{99}$

Tovább árnyalja a kép definiálásának nehézségeit az az eset, amikor a kép mozgással és hanggal telítődik. A mozgóképekre végképp nem lehet alkalmazni azokat a jellemzőket, amelyeket a mủvészettörténeti megközelítésủ képfogalom taglalásánál, vagy a fogalmat ilyen értelemben használó elemzéseknél szokás. Nem csak azért, mert a hallásunk útján is dekódolunk belöle információkat, hanem azért is, mert ott a különböző kompozíciók egymásutániságának, a montázs eszköztárának, az időnek és a ritmusnak - tehát a viszonyrendszernek - óriási a szerepe.

Jól látható tehát, hogy a kép fogalmának definiálása, a képek családfájának felállítása és a különféle felfogású képfogalmak strukturálása napjainkban mennyire nehézkes, hiszen ezen tevékenységek elé gátat vet az a tény, hogy a feladatot nem lehet egyértelműen egyik vagy másik tudományterület körébe rendelni. Ahhoz, hogy vizsgálódásunk tárgya körvonalazhatóbbá váljék, és a kép önmagában lévő alkotásként való értelmezése mellett a kép mint társadalmi produktum és mint kommunikációs jel fogalma is megközelíthető legyen, tekintsük át azt a folyamatot, amely során a kép a művészettörténet közegéből más tudományterületek érdeklődésének is középpontjába került, illetve melynek során kialakult egy egységes, de több diszciplínát is felsorakoztató képtudomány iránti igény.

http://www.renyiandras.hu/index.php?option=com_content\&view=article\&id=139:az-elfojtott-patoszformulai\&catid=60:mtoerteneszekrl\&Itemid=159, 2009. (letöltés: 2017.10.20.)

${ }^{99}$ Horányi Özséb (szerk.): A sokarcú kép. Válogatott tanulmányok a képek logikájáról. 2. módosított kiadás. Typotex, Budapest, 2003. 14. 


\section{I.2.2. A képek kultúrájában bekövetkezett változások és fordulópontok}

Ahhoz, hogy megértsük, miből adódnak és miben állnak azok az új feladatok, amelyekkel a képek tanulmányozása során szembe kell néznünk, és milyen megközelítésben foglalkozhatunk velük, először vissza kell tekintenünk ezek kiindulópontjaira. Érdemes egy kicsit hosszabban elidőzni a képekkel kapcsolatos fordulópontok körül, pontosabban a feltételezett fordulópontok, és a megjósolt paradigmaváltások, közöttük a művészet vagy a müvészettörténet végét meghirdető koncepciók körül, amelyek elvezetnek az aktuális változások értelmezhetőségéhez. Korábban már beszéltünk fordulópontokról a megfigyelő pozíciójának változása kapcsán, ezek azonban csak részben esnek egybe a képkultúra feltételezett paradigmaváltásaival.

Giorgio Vasari olasz építész, manierista festő, müvészeti író bizonyos értelemben már 1550 körül beharangozta a müvészet végét. Megírta A legkiválóbb festők, szobrászok és épitészek élete ${ }^{100}$ című munkáját, és letette a voksát amellett, hogy Michelangelo már mindhárom szépművészeti ágnak megadta a végleges formát. Úgy vélte, Raffaelloval, Leonardoval, Tizianoval többé-kevésbé lezárult a művészetek tökélyre juttatása, a tökéletes művek létrehozásához szükséges elvek már világosan ki vannak fejtve. Ám tudjuk, hogy a következő évszázad még olyan müvészeket adott nekünk, mint Caravaggio, Rubens, Velázquez, Rembrandt vagy El Greco.

A müvészet végpontja felé közelítés gondolata azonban az 1920-es évektől kezdve kap igazán hangsúlyt - ám már Vasari elégedettsége nélkül, inkább a haldoklás hasonlatával összekapcsolva, részben a spengleri gondolatok hatása alatt - majd a XX. század második felében válik uralkodóvá a művészetfilozófiai diskurzusokban. Máté Zsuzsanna e „művészet vége” diskurzusoknak négy alapvető irányultságát véli elkülöníthetőnek. Megkülönbözteti a müvészet és a filozófia; a művészet és (fejlődés)története; a művészet és a metafizika, valamint a művészet és az európai (nyugati) kultúra civilizációs periódusának kölcsönviszonyában létrejött felfogásokat. ${ }^{101}$

E teóriák egyik kiindulópontját Hegel 1827/28-as gondolatai jelentették. Esztétikai előadásaihoz írt előszavában lejegyezte, hogy „vallásunknak és észműveltségünknek szelleme” túljutott azon a fokon, amelyben a müvészet az abszolútum tudatosításának legfőbb módja,

\footnotetext{
${ }^{100}$ Vasari, Giorgio: Le vite de'piu ecellenti pittori, scultori ed architetti. Firenze, 1550. Magyarul megjelent: $A$ legkiválóbb festők, szobrászok és épitészek élete. Vál.: Vayer Lajos. Ford.: Zsámboki Zoltán. Magyar Helikon, 1978.

${ }^{101}$ Máté Zsuzsanna: A „,müvészet vége” dilemma müvészet/filozófiatörténeti diskurzusáról. In: Magyar Müvészet. A Magyar Müvészeti Akadémia Lapja. 2018. VI. évfolyam 2. szám. 32.
} 
illetve azon, hogy a művészet alkotásait ,istenítve tisztelhessük s imádhassuk.” ${ }^{102}$ A művészet már nem adja meg a szellemi szükségleteknek azt a kielégülését, amelyet korábban nyújtott. „Mindezen vonatkozásokban a művészet legmagasabbrendű meghatározása szemszögéből nézve, számunkra a múlté, s azé is marad. (...) A művészet tudománya ezért sokkal inkább szükséglet a mi korunkban, mint azokban a korokban, amelyekben a müvészet önmagáért véve, mint művészet, már tökéletes kielégülést nyújtott. A művészet gondolati vizsgálódásra hív bennünket, éspedig nem abból a célból, hogy ismét müvészetet hozzunk létre, hanem, hogy

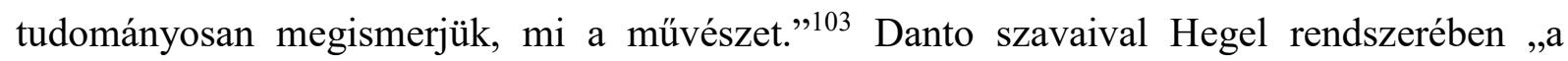
müvészet történelmi küldetése az, hogy lehetővé tegye a filozófiát, s ennek eljövetele után a

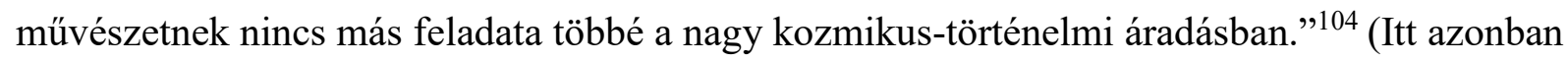
meg kell jegyeznünk, hogy Danto Hegel-értelmezésével nem mindenki ért egyet. Máté Zsuzsanna például úgy véli, hogy ez a felfogás egyoldalú, hiszen Hegelnél a művészet feladata nem a filozófia lehetővé tétele, mivel ez inkább egy következmény a hegeli gondolatmenetben. ${ }^{105}$ )

Walter Benjamin gondolatmenetében is megjelenik a müvészet funkciójának megváltozása, aurájának elenyészése. 1936-os, A müalkotás a technikai sokszorosithatóság korában c. esszéjében ${ }^{106}$ megállapítja, hogy véget ért az a korszak, amelyben a zseni által alkotott mű megismételhetetlensége révén különös rangot, megszentelt aurát kapott. A fotó, a film, az ipari produkciók, a sokszorosíthatóság új távlatokat nyit: lehetőség nyílik olyan müvészetek müvelésére, ahol eltünik a különbség eredeti és kópia között. A reprodukálhatóság révén egy mindenki számára hozzáférhető művészet jön létre. Benjamint azonban Theodor Adorno figyelmeztette: a technikai sokszorosíthatóság kétes értékü találmány, amely kedvez a giccs és a kommersz terjedésének, és fegyverré, emberek manipulálásának eszközévé válhat. Ugyanakkor megállapította: a modern müvészet általános elleni törekvése az ember egyediségének felismeréséhez is hozzásegíthet. ${ }^{107}$

A modern müvészetek megjelenésével egyre többen hirdették meg a müvészet válságát vagy legalábbis nagymérvű változását. Egyre nyilvánvalóbbá vált, hogy a müvészet rég nem felel meg annak az elvárásnak, amivel korábban a szépmüvészetekre tekintettünk. Perneczky

\footnotetext{
${ }^{102}$ Hegel, G.W.F.: Esztétikai előadások I. Bevezetés az esztétikába. Akadémiai Kiadó, Budapest,1980. 11.

103 U.o. 12-13.

${ }^{104}$ Danto, Arthur C.: Hogyan semmizte ki a filozófia a müvészetet? Atlantisz kiadó, Budapest, 1997. 30.

${ }^{105}$ Máté Zsuzsanna: A „müvészet vége” dilemma müvészet/filozófiatörténeti diskurzusáról. In: Magyar Művészet. A Magyar Müvészeti Akadémia Lapja. 2018. VI. évfolyam 2. szám. 33-34.

${ }^{106}$ Benjamin, Walter: Müalkotás a technikai sokszorositás korában. In: Benjamin, Walter: Kommentár és prófécia. Gondolat, Budapest, 1969.

107 Adorno Benjaminhoz írt levelét idézi: Perneczky Géza: A ,müvészet vége” - baleset vagy elmélet? In: Perneczky Géza (szerk.): A müvészet vége? Európai füzetek, 1. szám. Új Világ Kiadó, 1995. 18.
} 
Géza rámutat, hogy vannak, akik elméleti szinten, racionális érvekkel alátámasztva, szisztematikusan felépített koncepciók alapján jósolják meg e változást, és van egy fordított orákulumszerü hozzáállás is, amely abból táplálkozik, hogy valami nagyszerű már mögöttünk van, és nem jön többé vissza. ${ }^{108}$ Perneczky szerint voltak, akik a befogadás, illetve a modern müvészet befogadhatatlansága felől közelítettek a változásokhoz, ám ez a vita többnyire az akadémizmus és a progresszív irányzatok közötti versengésbe torkollt, illetve annak eszközévé vált. A posztmoderntől pedig különösen kiemelt témává vált a müvészet halála és a művészet öngyilkosságának teóriája: a ,jó” művészet a kommersz és a giccs elől menekülve az aszkétikus önrombolás, a hallgatás vagy önmaga kiürítésének útját választja.

Thomas Kuhn amerikai tudománytörténész és a tudományok filozófusa 1962-ben kiadja A tudományos forradalmak szerkezete ${ }^{109}$ c. könyvét, bevezetve a „paradigmaváltás” fogalmát: A tudományos területek időszakos paradigmaváltásokon mennek keresztül, nem pedig lineáris és folyamatos úton haladnak előre. Ezek a paradigmaváltások új megközelítéseket nyitnak meg olyan felfogási folyamatok iránt, melyeket a tudósok azelőtt soha nem tartottak volna érvényesnek. Kuhn gondolatai - némi csúszással - hatottak a müvészetelméletre is: Gianni Vattimo olasz filozófus 1983-ban megírja A müvészeti forradalmak szerkezete ${ }^{110}$ címü tanulmányát. Perneczky Géza értelmezése szerint Vattimo úgy látja, a modernitás megélése vált alapvető értékké, a kulcsfogalom pedig az „új”. Az újnak a szállítója lesz a kor hőse, és a haladásba vetett felszínes hit válik uralkodóvá. Az ideiglenességbe való beletörődés kirántja a talajt a művészeti paradigmaváltások mélyebb értelmü jelentősége alól. A tudományos paradigmaváltások elve a tetszés kategóriájába emeli át a tudományt, esztétizálja azt. A müvészet viszont ezzel szemben racionalizálódott és technicizálódott. Elérkezett az a pillanat is, amikor a művészet figyelmét csak a technikai apparátus, az állandó jelen köti le, hasonló állapotba kerül, mint amit Arnold Gehlen „,történelem utáni”-nak nevez - foglalja össze Perneczky Vattimo legfontosabb meglátásait. ${ }^{111}$ (A filozófiai antropológiával foglalkozó Arnold Gehlen a festészet alkotásait egyszerre tekinti müvészeti produktumnak és a társadalmi mozgás tükröződésének. A nonfiguratív festészet szükségszerüségét és létjogosultságát kutatva a hangsúlyt az emberi aktivitásra, illetve az ösztönösség és a tudatos ellenőrzés kölcsönhatására

\footnotetext{
${ }^{108}$ Perneczky Géza: A „müvészet vége” - baleset vagy elmélet? In: Perneczky Géza (szerk.): A müvészet vége? Európai füzetek, 1. szám. Új Világ Kiadó, 1995.13

${ }^{109}$ Kuhn, Thomas: A tudományos forradalmak szerkezete. Osiris, Budapest, 2002.

${ }^{110}$ Vattimo, Gianni: La struttura delle rivoluzioni artistiche. In: Rivista di estetica, 1983/14-15.

111 Perneczky Géza: A „,müvészet vége” - baleset vagy elmélet? In: Perneczky Géza (szerk.): A müvészet vége? Európai füzetek, 1. szám. Új Világ Kiadó, 1995. 17.
} 
helyezi. ${ }^{112}$ ) Ilyen körülmények között a művészetnek sem lehet többé (hagyományos értelemben vett) története. A müvészet halálát beharangozzák, de az egyúttal mindig ki is tolódik: „Morte o tramonto dell'arte” (Vattimo esszéjének címe, a tramonto naplementét és hanyatlást is jelent): egy végtelenített naplementének, örök hanyatlásnak vagyunk tanúi. ${ }^{113}$ Vattimo szerint a müvészet meghosszabbított haldoklása csak egy aspektusa lehet egy egyetemesebb, metafizikai naplementének - írja Perneczky. ${ }^{114}$

A „müvészet halála”-koncepciók indukátorai között természetesen ott vannak azok, a XX. század művészetében zajló folyamatok, amelyek mind több és több teoretikust ejtettek gondolkodóba: a dadaisták, a ready-made, a body-art, az eseményművészet, a performance és egyéb provokatív irányzatok, a közvéleményt megbotránkoztató alkotások. Yves Klein 1958ban a párizsi Iris Clert galériában nyílt kiállításának hófehér falú, üres termeiben semmit sem lehetett látni. A „láthatatlanság és a meghatározhatatlanság” kiállítását a művészettörténészek többre tartották egyszerü csínytevésnél, a kimondhatatlan csend megnyilvánulásának, az éppen adott történeti és kulturális helyzet kiemelkedően izgalmas dokumentumának tartották. Sokakat megihlettek Andy Warhol müvei is. Ahogy arról az externális küszöbök kapcsán korábban már szót ejtettünk: Danto a Brillo-dobozok kapcsán teszi fel a kérdést: Ha nem az áruház kirakatában, hanem a galériában van, akkor már müvészet? Mi a különbség? Nyilvánvalóan csak teoretikus, filozófiai különbség van: kimondjuk, mi a művészet és mi a nem-művészet. Danto szerint itt véget ér az a korszak, amelyben a müvészetnek bármiféle története, paradigmája lehetett. ${ }^{115}$ Ám attól, hogy mi így látjuk, nem biztos, hogy ez a végső válasz. A mủvészet továbbra is élni fog, legfeljebb a müvészet története jutott el (a mi számunkra) a befejezéshez, hiszen felvetődhet annak a lehetősége, hogy ezt követi a történelem utáni, vagy a történelmen kívül rekedt művészet. Perneczky Géza így fogalmaz: „A legtöbb, amit a gondolkodó elérhet - és ezt tette Danto is - az, hogy a paradigmák eddigi szekvenciáját szemlélve arra a következtetésre jusson, hogy elképzelhetők olyan nagyobb egységek és tendenciák, olyan (nevezzük így:) mega-paradigmák, amelyeket az eddigi tapasztalatok alapján, általánosítással, mint hipotéziseket építünk fel."116

\footnotetext{
${ }^{112}$ Gehlen, Arnold: Kor-képek 1907-1914. A modern festészet szociológiája és esztétikája. Gondolat, Budapest, 1987.

${ }^{113}$ Vattimo, Gianni: Morte o tramonto dell'arte. In: Rivista di estetica, 1980. Nr. 4. / Könyvalakban: La fine della modernità. Gerzanti Editore, Milano, 1985.

${ }^{114}$ Perneczky Géza: A „müvészet vége” - baleset vagy elmélet? In: Perneczky Géza (szerk.): A müvészet vége? Európai füzetek, 1. szám, Új Világ Kiadó, 1995. 17.

${ }^{115}$ Danto, Arthur C.: Történetek a müvészet végéröl. In: Perneczky Géza (szerk.): A müvészet vége? Európai füzetek, 1. szám, Új Világ Kiadó, 1995.

116 Perneczky Géza: A müvészet vége - baleset vagy elmélet? In: Perneczky Géza (szerk.): A müvészet vége? Európai füzetek, 1. szám, Új Világ Kiadó, 1995. 26.
} 
A müvészet vége-teóriákkal párhuzamosan és azokkal összefüggésben - bizonyos értelemben talán azokból következően - megindult egy aktivitás a képekkel kapcsolatos szakirodalomban, amely a művészettörténeti megközelítésektől való tudatos eltávolodást, a képek komplexebb, több diszciplínát igénybe vevő megközelítését preferálja. Ehhez szükség volt azokra a felismerésekre, amelyek a művészet megváltozott funkciójához és a művészet vége-elméletekhez kapcsolódtak, mintegy rávilágítva arra is, hogy egyre nő azoknak a képeknek a száma, amelyek nem rendelkeznek és nem is akarnak rendelkezni azzal az aurával, amely korábban a müvészeti alkotásokat jellemezte.

\section{I.2.3. Illetékességi vita a képek körül}

Mióta elképesztő módon megsokasodott körülöttünk a nem müalkotásnak szánt képek száma, azóta egyértelművé vált, hogy a képekről való gondolkodás, a képek elemzése, a képek sorsunkra és gondolkodásunkra gyakorolt hatása nem csupán a müvészettörténészek jussa. (Még akkor sem, ha a művészettörténet Bildwissenschaft-ként tekint önmagára.) A képi fordulat ideája által kiváltott diskurzus szemléletváltást hozott a képek tanulmányozásába, így azok önmagukban létező alkotásokként való értelmezése mellett egyre nagyobb hangsúlyt kap a képek mint társadalmi produktumok és mint kommunikációs jelek értelmezése. A művészettörténeti értelmezéskonstrukció elsődlegességének megkérdőjeleződését jól mutatja, hogy a Warburg-iskolához tartozó (és egyébként Erwin Panofskyra is nagy hatást gyakorló) Fritz Saxl halála évében, 1948-ban már megjegyezte egy előadásában, hogy korunk nem az ész kora, hanem vizuális kor, és a művészet történetéről való gondolkodás nem különülhet el a történeti, politikai, irodalmi, vallási vagy filozófiai megközelítésektől. ${ }^{117}$

A művészettörténet válságba jutásáról gondolkodó Hans Belting is rámutat arra az illetékességi vitára, amely a művészettörténet és a médiatörténet között zajlik a képeket illetően. ${ }^{118}$ „Napjainkban a művészetkutatás olyan környezetben folyik, amelyben a technikai kép médiumai messzemenően meghatározzák világképünket és a valóságról kialakított felfogásunkat, fơként ha félreismerjük tulajdonképpeni ideológiai szándékukat"119 - írja Belting, aki szerint a képek iránt támadt újkeletü érdeklődés közegében a müvészettudomány

\footnotetext{
${ }^{117}$ Saxl, Fritz: Why art history = F.S., Lectures I., London, Warburg Institute, 1957, 346-353. Összegzi: Bacsó Béla: A kép-tudomány margójára. In: Studia Litteraria: Kép, látvány, szöveg. 2013/1-2. LII. évfolyam, 9.

118 Belting, Hans: Médiatörténet és müvészettörténet. Első alkalommal 1983-ban jelent meg A müvészettörténet vége? (Das Ende der Kunstgeschichte?) című tanulmány részeként, amit tíz évvel később átírt és bővített a szerző - ekkor már elhagyva a kérdőjelet a cím végéröl.

119 Belting, Hans: A müvészettörténet vége. Az első kiadás újragondolt változata - tíz év után. Atlantisz könyvkiadó, Budapest, 2007., 234.
} 
szélesebb körü illetékességre is igényt tarthatna, ám fél, hogy árulást követ el az alkotások müvészi mivoltával szemben. A médiaelmélet viszont csak a technikai médiumokról beszél, a régi médiumokat figyelmen kívül hagyja, mondván, az mind „,müvészet”. Belting nem helyesli, hogy a képek egységét két pólus, a médiumok és a müvészet között osztják fel, mint ha szakadék választaná el őket egymástól. Hiszen egykor a legtöbb kép egyszerre volt médium és müvészet: információhordozókként is funkcionáltak, de önnön esztétikájuk révén is hatottak. És Belting rámutat egy komoly ellentmondásra is: a művészettudomány a kőkortól napjainkig mindent müvészetté nyilvánított, amivel foglalkozni kívánt, noha nem volt minden mủvészet ma viszont elzárkózik a médiumoktól, mondván, hogy azok nagyrészt kilógnak a művészet kategóriájából. Felveti a lehetőségét, hogy ezen ellentmondások belátásának a következménye talán egy új, átfogó képtörténet lesz, amely integrálná, de nem szüntetné meg az eddigi müvészettörténetet. „A képtörténet saját jogán kezelné a képi médiumokat, bárhol bukkannak is fel, amiként a müvészetet is akként azonosíthatná, ahol és amikor az művészetként, a maga elvárásaival és történelmi szempontból fontos keretei között szólal meg."120

W.J.T. Mitchell, aki 1986-os Iconology címü könyvében interdiszciplinárisan közelít a kép fogalmához, megvizsgálja azt többféle, intézményesült diskurzusban: a filozófia, az irodalomkritika, a müvészettörténet és a teológia területén. Mitchell bírálat tárgyává teszi azt a módot, ahogy e területek az egymástól kölcsönzött képfogalmakat használják. Úgy véli, a képekre inkább egy nagy családként kellene tekinteni, melynek tagjai szétszóródva vándorolnak időben és térben, miközben változásokon esnek át. ${ }^{121}$

Mitchell megrajzolja a képek családfáját, amelynek minden ága központi jelentőségű valamelyik elméleti diszciplína diskurzusában. Az egyik ág a grafikus képeket, festményeket, szobrokat, építészeti ábrázolásokat jeleníti meg, amelyek a művészettörténet felségterületére tartoznak. Az optikai képek (tükrök, kivetítések) ága a fizikához, a verbális képek (metaforák) ága az irodalomkritikához, a mentális képek (álmok, leírások, ideák) pedig a pszichológiához kapcsolódnak. Mitchell egy ötödik ágat is rajzol a családfára, ez az észlelési képeket jelöli, amelyek szélesebb területet fognak át, ahol a neurológusok, fiziológusok, optikusok is érintettek. Úgy véli, a különböző típusú képek magyarázói hajlamosak rá, hogy a többi típust háttérbe szorítva csak a saját, fö témájukat vizsgálják. ${ }^{122}$

\footnotetext{
${ }^{120}$ Belting, Hans: A müvészettörténet vége. Az elsö kiadás újragondolt változata - tíz év után. Atlantisz könyvkiadó, Budapest, 2007., 238.

${ }^{121}$ Mitchell, W.J.T: Mi a kép? In: Szönyi György Endre - Szauter Dóra: A képek politikája. W.J.T. Mitchell válogatott írásai. Jate Press, Szeged, 2012. 17.

${ }^{122}$ U.o. 19.
} 


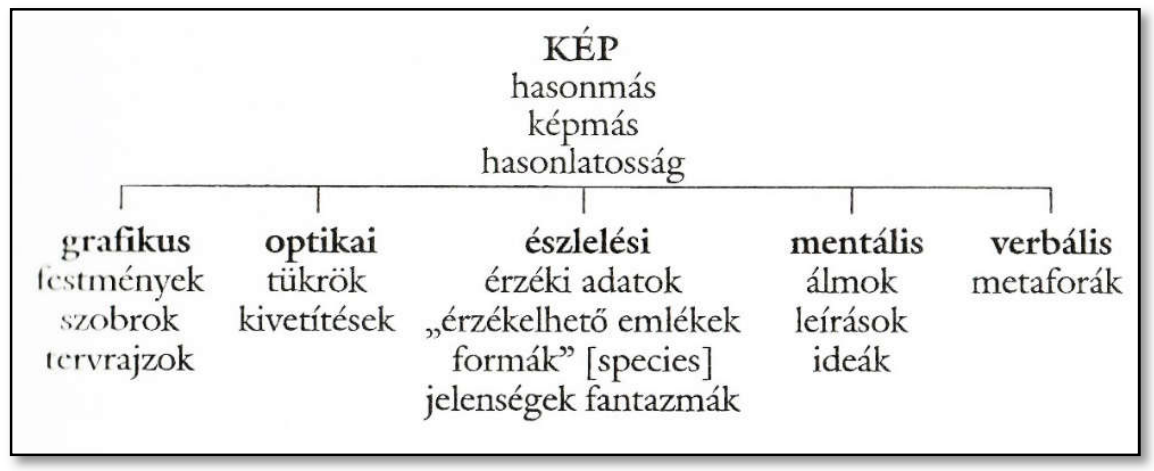

Mitchell igy ábrázolja a képek családfáját. Forrás: Szőnyi György Endre - Szauter Dóra: A képek politikája. W.J.T. Mitchell válogatott írásai. Jate Press, Szeged, 2012. 17.old.

Közelebb vihet a képek lényegéhez, ha megnézzük, hogy a Mitchell által megrajzolt családfának mely tagjai tekinthetők szigorúan, valódi és szó szerinti értelemben képeknek, és melyek azok, amelyek csupán egy kitágított képfogalom részei, vagy csupán metaforikusan tekinthetők képeknek. Mitchell ezt a logikát követve megkérdőjelezi a mentális illetve a verbális képek helyét a családfában. Előbbiekét azért, mert nem szilárdak és állandóak, illetve nem kizárólag vizuális természetűek, hanem más érzékszerveket is foglalkoztatnak. (A mentális ábrázolás fogalmát a pszichológia egy időre el is vetette, bár napjainkban újra kutatási témává vált.) Kirekeszthetők a verbális képek is, amelyek nem is feltétlenül tartalmaznak érzéki összetevőket. ${ }^{123}$ Emellett érvel Philip Nicholas Furbank is, aki szerint korlátozni kellene a „kép” szó használatát annak természetes értelmére, amely hasonmást (likeness), képet (picture) vagy simulacrumot jelent. ${ }^{124}$ Ám e megkérdőjelezés után Mitchell mégis arra jut, hogy ,a valódi, igazi képek több közös vonást mutatnak törvénytelen sarjaikkal, mint amennyit bevallani szeretnénk." 125 Az ,igazi” képek sem szilárdak, statikusak vagy állandóak, és a szemlélök nem észlelik öket határozottabban, mint az álomképeket, valamint nem kizárólag vizuálisak valamilyen kitüntetett értelemben, hanem több érzékszervet igénybe vevő felfogást és értelmezést igényelnek.

De hogy érthetőbbé váljon, hol van a probléma forrása, lépjünk egy kicsit visszább az időben. Ha a legszűkebb értelemben vett (grafikus, technikai) képekkel való foglalkozást tekintjük, azt láthatjuk, hogy a képek elemzését kialakulása pillanatától a müvészettörténet tudománya ragadta magához, mindenekelőtt leíró-, osztályozó és rendszerező segédtudománya, az ikonográfia révén. Az ikonográfia tárgya elsősorban a képzőművészeti alkotások formai

\footnotetext{
${ }^{123}$ U.o. 20.

${ }^{124}$ Furbank, P.N.: Reflections on the Word „Image”. Secker\&Warburg, London, 1970.

125 Mitchell, W.J.T.: Mi a kép? In: Szőnyi György Endre, Szauter Dóra: A képek politikája. W.J.T. Mitchell válogatott írásai. Jate Press, Szeged, 2012. 21.
} 
szempontból való leírása, a képelemek egymáshoz való viszonyának vizsgálata. Beazonosítja a képek szereplöit, elemeit, motívumait, illetve az ábrázolásokat szöveges forrásokhoz (pl. Biblia) kapcsolja. Az ikonográfia mellett az 1920-as évekre kialakult az ikonológia, amely a formai elemzés mellett és azt kiegészítve mindenekelőtt egy műalkotás szimbolizmusát értelmezi. E másik segédtudomány célja, hogy a müalkotást egy világnézet vagy ideológia megtestesüléseként, szimbólumaként, kordokumentumként értelmezze. Az ikonológia a tulajdonképpeni tartalmat, a jelentés mélyebb, az ikonográfia módszerével fel nem tárható rétegeit kutatja.

Az ikonológiai módszert először Aby Warburg alkalmazta 1892-ben Botticelli két képére. ${ }^{126}$ A módszert eleinte a Warburg-iskola módszerének nevezték, amelyet tanítványai és munkatársai alkalmaztak, mint pl. Gertrud Bing, Fritz Saxl, Walter Solmitz, Edgar Wind. Erwin Panofsky 1939-től háromlépcsős elemzéssémává fejlesztette tovább a Warburg-iskola módszerét. A preikonografikus leírás szintjén a kép színeit és vonalait figurákként, dolgokként ismerjük fel. Az ikonográfiai elemzés az ábrázolások, történetek és allegóriák szintje, mely a képet inspiráló szövegek ismeretét feltételezi. Az ikonológiai értelmezés pedig azokat a szellemi tartalmakat fejezi ki, amelyek a kép keletkezésének idején hatottak. ${ }^{127}$ Ezt egészíti ki később Max Imdahl egy negyedik szinttel, a képi szemléletességre vonatkozó ikonikával: „ez egy olyan szemlélet, amely magában foglalja a képen láttatott reflexióját, valamint a csak képileg szemléltethető reflexióját egyaránt."128

Az ikonológiáról vallott korábbi felfogást a már említett Mitchell alaposan felforgatta. Kritikaként fogalmazta meg, hogy az ikonológia a logosz ikon feletti uralmával kecsegtet, és mindenáron világnézetekbe akarja tolni a képeket. Magán viseli egy ősi paradoxon sebhelyeit: az ember a „beszélő állat”, a kép pedig a „néma állat”, tehát a nyelv magasabb rendű, a kép pedig a vad, a gyermeki, a tömegek médiuma. E paradoxont az ikonológia nem képes kitörölni működéséből. ${ }^{129}$ Mitchell több helyen rámutat a képektől való félelem (ikonofóbia) megnyilvánulásaira is. Mitchell szerint ideje feladni a képek megértését irányító metanyelv vagy diskurzus fogalmát, és inkább vizsgáljuk meg azt a módot, ahogyan a képek magukat próbálják kifejezni. Mondjunk le a tudományos elmélet reményéről, és rendezzük meg az ikon

\footnotetext{
126 Warburg, Aby: Sandro Botticellis „,Geburt der Venus” und „Frühling”: eine Untersuchung über die Vorstellungen von der Antike in der italienischen Frührenaissance. L. Voss, Hamburg, 1893.

${ }^{127}$ Panofsky, Erwin: Ikonográfia és ikonológia: bevezetés a reneszánsz müvészet tanulmányozásába. In: Panofsky, Erwin: A jelentés a vizuális müvészetekben. Gondolat, Budapest, 1984. 284-308.

128 Imdahl, Max: Ikonika. Képek és szemlélésük. In: Bacsó Béla (szerk.): Kép, fenomén, valóság. Kijárat, 1997. 260.

${ }^{129}$ Mitchell, W.J.T.: Mi a kép? In: Szőnyi György Endre, Szauter Dóra: A képek politikája. W.J.T. Mitchell válogatott írásai. Jate Press, Szeged, 2012. 144.
} 
és a logosz találkozóját olyan témákban, mint a müvészeti hagyományok eszményképe. Mindez tovább lendítheti az ikonológiát az emberi szubjektum alapvető konstrukciójába, melynek összetevői a nyelv és a leképezés. ${ }^{130}$

Mitchell új szempontként bevezette a képek politikáját, azt kutatva, milyen érzelmiideológiai és politikai aktus fejthető fel mögöttük. Az izgatta, hogyan kezelik az egyes korokban a képet, miért favorizálja egy korszak egyszer a szavakat, másszor a képeket, és miért, hogyan próbálják meg ezeket kijátszani egymás ellen. 1994-es Picture Theory címü könyvében számba veszi, mi minden tartozik hozzá a kép és képiség diskurzusához. Bevezeti a metaképek fogalmát, amelyeket elméleti igénnyel fellépő vizuális reprezentációkként definiál. A kép/szöveg (image/text) kifejezés bevezetése a képek és szavak elválaszthatatlanságát demonstrálja, hiszen kép és szöveg a történelem folyamán mindig is elválaszthatatlan összefonódásban létezett. Felveti azt a lehetőséget, hogy teremthetünk nekik egy közös platformot is, amely új utakat nyit a téma vizsgálatában.

Az illetékességi vita nem csupán az „álló”131, de a mozgóképek esetében is számos esetben tetten érhető. A filmelmélet és filmtörténet sok esetben kirekeszti a nem müvészi céllal létrehozott mozgóképsorokat, a médiatudomány pedig gyakran elfelejti magába integrálni a filmművészetet, és csupán azokkal a mozgóképsorokkal foglalkozik, melyek a valóságban történteket dokumentálják, vagy az olyan fikciós felvételekkel, amelyek inkább a propaganda világához tartoznak. Ahogyan nem igazán létezik (még) átfogó képelmélet, úgy átfogó mozgóképelmélet sincs. Itt is látható a Belting által a képekre vonatkoztatott és nehezményezett tendencia: a mozgóképeket is két pólus, a médiumok és a müvészet között osztják fel, noha talán ezek között sincs minden esetben akkora szakadék, mint amit a szakemberek hozzáállása alapján gondolnánk. És ez a megállapítás egy újabb kérdés felvetéséhez juttat el bennünket: a mozgóképek vizsgálata mennyire férhet bele abba az átfogó képtudományba, melyet Mitchell és Belting hiányolnak? Kezelhető-e együtt kép és mozgókép? Bizonyára megfogalmazhatók olyan tanulságok, amelyek mindkettőre egyformán igazak, de kétség kívül vannak olyan témakörök is, amelyek esetében meg kell különböztetnünk, hogy vizsgálódásunk tárgyát mely csoportba tartozó képek teszik ki.

\footnotetext{
${ }^{130}$ U.o. 144.

131 Az idézőjelet indokolja, hogy a mentális képeknek nevezett képcsalád tagjai sem feltétlenül statikusak. Dinamikusan változhatnak, miközben az emlékezetünkből felidézzük őket. Erről bővebben esik majd szó az emlékezettel kapcsolatos fejezetben.
} 


\section{I.3. Új utak a képek tanulmányozásában}

„A képi fordulatot azért hirdették meg, hogy a folyamatosan növekvö »képözönt" (...) fogalmilag mederben tartsuk, s a képek elemezhetöségét a jelenkor kritikai filozófiájának középpontjába állitsuk."132

Horst Bredekamp

Láthattuk tehát, hogy több nagy gondolkodó véli úgy, hogy a képzőművészetben a XIX. illetve a XX. században lényegi változások történtek, és láthattuk azt is, hogy ebböl adódóan egyre többen sürgetik egy átfogó, képekkel foglalkozó tudomány létrejöttét. Míg korábban szinte minden ember alkotta képet a müvészettörténet vizsgált, most egyre nagyobb azon képek halmaza, amelyekkel e tudomány már nem tud vagy nem akar mit kezdeni.

Adódik a következő kérdés: hogyan, milyen kiindulópontokból érdemes tehát közelíteni a képekhez, milyen szempontok köré szőhetjük vizsgálódásainkat, mi tarthatja mederben azokat? Adott egy fogalom, amely egy olyan területet jelöl ki, amelyre nem csupán a vizuális művészeti alkotások, de a legkülönbözőbb célokkal létrejövő fizikai képek besorolhatók: ez a vizuális kultúra. A vizsgálódást tehát ennek megközelítésével érdemes folytatni. A vizuális kultúra azonban nem kapcsolható egyértelmüen egy konkrét diszciplínához, így ebben az alfejezetben a több diszciplína felhasználásával történő megközelítésmód előnyeit és hátrányait is sorra veszem, eljutva ahhoz a kérdéshez, hogy mire kötelez a képi fordulat, melyek azok az új, megkerülhetetlen igények, amelyeknek napjaink képekkel foglalkozó kutatóinak eleget kell tenniük.

\section{I.3.1. A vizuális kultúra fogalmának értelmezési lehetőségei}

A hagyományos értelemben vett müvészettörténet Danto és Belting által jól körvonalazott zsákutcába jutása után, napjainkban egyre többször odateszik a művészettörténet szó után azt a kifejezést, hogy vizuális kultúra. Kibővült ezzel a terminológiával az iskolában oktatott rajzművészettörténet tantárgyak elnevezése és a felsőoktatás müvészettörténeti (valamint sokszor filmelméleti és filozófiai/kultúraelméleti tanszékei is) szívesen foglalják a nevükbe. Látszólag tehát megvan a megoldás, a vizuális kultúra, vagy a vizuális kultúratudomány lehet az a tudományterület, amely megfelelö platformot teremthet a képekkel kapcsolatos tudományos kutatások számára. De hogyan is értelmezhetjük a vizuális kultúra fogalmát?

\footnotetext{
${ }^{132}$ Bredekamp, Horst: Fordulópontok. Az iconic turn ismertetőjegyei és igényei. (ford.: Kékesi Zoltán) In: Nagy Edina (szerk.): A kép a médiamüvészet korában. L’Harmattan, 2006., 17.
} 
E fogalom értelmezésének problémakörei az 1990-es évek közepétől kerültek igazán előtérbe, noha már korábban is voltak erre kísérletek, melyekben hazai szakemberek is jeleskedtek. Horányi Özséb például már 1980-ban leírja, hogy „a vizuális kultúra területébe tartozik a társadalmi praxis ( $\mathrm{s}$ benne - természetszerüen - az ember egyéni viselkedésmódja, életmódja) minden olyan megnyilvánulása, amelynek (tárgyiasult formában) közvetlen vagy közvetett eredményeként vizuális jelenségek jönnek létre." ${ }^{133}$ Míg Miklós Pál definíciója szerint: „Vizuális kultúrán értem egyrészt (a) a szem számára (is) felfogható teljes tárgy- és jelenségvilágot (korpusz), másrészt (b) a teljes vizuális tárgy- és jelenségvilág ember általi használatát - alakítását, teremtését és felhasználását (performancia), végül (c) a teljes vizuális tárgy - és jelenségvilág használatára való képességet - alkotóképességet és vele élni tudást (kompetencia)." ${ }^{134}$ E meglehetősen tág megjelölések után azonban azt láthattuk, hogy inkább azok a próbálkozások kerültek a figyelem középpontjába, amelyek a vizuális kultúrát a dokumentálás, a marketing és a szórakoztatás céljára létrejövő képek dömpingjének aktualitása irányából közelítették meg.

Mitchell, ${ }^{135}$ Nicholas Mirzoeff, ${ }^{136}$ James D. Herbert ${ }^{137}$ és még számos kutató járta körbe a fogalmat, hasznos megállapításokat téve, ám munkáik végkicsengése többnyire megegyezik abban, hogy általánosan használható, pontos definíció nem adható, ahogyan a kultúra fogalmára sem létezik ilyen. Mirzoeff nem kevesebbet állít, mint azt, hogy a vizuális kultúra ma nem egyszerűen része a mindennapi életnek, hanem maga a mindennapi élet. Felhívja a figyelmet a vizuális kultúra és a posztmodernizmus összefüggéseire, mondván, hogy utóbbinak egyik okozója a kultúra vizuális krízise. Szerinte az a szakadék, amely a kortárs kultúrában a vizuális tapasztalatok bősége és a megfigyelések elemzésének képessége között húzódik, a kutatási területként felfogott vizuális kultúra lehetőségét és szükségességét egyaránt jelzi. ${ }^{138}$

Mirzoeff a vizuális kultúrára taktikaként tekint, amellyel a fogyasztó szempontjából lehet vizsgálni életünk eredettörténetét és funkcióit. Rámutat, hogy a vizuális kultúra kifejezés jelentése változáson ment át: „míg korábban egy hasznos kifejezés volt mindazoknak, akik müvészettörténettel, film- és médiatudománnyal, szociológiával vagy a vizualitás más

\footnotetext{
${ }^{133}$ Horányi Özséb: A vizuális kultúra szerepe a társadalmi fejlödésben és az életmód alakulásában. Az MTA Vizuális Kultúrakutató Bizottság számára készített vitaanyag. Budapest, Népmüvelési Intézet, 1980.

${ }^{134}$ Miklós Pál: Kép és kommunikáció. Budapest, MÚOSZ, 1980, 149.

${ }^{135}$ W. J. T. Mitchell: What is Visual Culture? In: Irving Lavin (szerk.): Meaning in the Visual Arts: Views from the Outside: A Centennial Commemoratum of Erwin Panofsky (1892-1968), Princeton Univ. Press, 1995

${ }^{136}$ Mirzoeff, Nicholas: Introduction: What is Visual Culture? In: Nicholas Mirzoeff (szerk.): Visual Culture Reader. Routledge, London, 1998.

${ }^{137}$ Herbert, James D.: Visual Culture / Visual Studies. In: Nelson, Robert S. - Schiff, Richard (szerk.): Critical Terms for Art History. University of Chicago Press, Chicago, 2003. 452-464.

${ }^{138}$ Mirzoeff, Nicholas: Mi a vizuális kultúra? In: Ex-Symposion, 2000/32-33. szám. Ex-Symposion Alapítvány, Veszprém, 2. old.
} 
aspektusával foglalkoztak, addig mára az interdiszciplináris kutatás egy divatos, bár ellentmondásos új eszközévé vált." ${ }^{139}$ - írja 1998-ban. ${ }^{140}$ A vizuális kultúra kutatási tárgyát azokhoz a vizuális eseményekhez köti, amelyek során a fogyasztó vizuális információhoz, jelentéshez vagy örömhöz akar jutni. A vizuálist mint szociális interakciót, vagyis az osztállyal, a fajjal, a természetes és társadalmi nemmel összefüggő identitások meghatározásának folyamatosan állásfoglalásra késztető helyét érti. A vizuális kultúrát tehát interdiszciplináris kategóriának tekinti, amelyet egy speciális, a látáson alapuló érzékelési rendszer jellemez.

A New York University professzora egy szemléletváltásra mutat rá fejtegetései révén. Gondolatai felvetik a lehetőségét annak, hogy a vizuális kultúra fogalma nem értelmezhető egységesen az időben kiterjesztve. Egészen mást jelentett a képek most tapasztalható áradata előtt, illetve mást jelent most, mióta - Gombrich gyakorta idézett kifejezésével élve - „olyan történeti korszak kezdetén vagyunk, amelyben a kép átveszi az írott szó helyét." ${ }^{141}$ Ám a Mirzoeff által is jelzett átalakulás dacára valamit nem szabad szem elől tévesztenünk. Igaz, hogy a vizuális kultúra kifejezés csak a '90-es évektől, a müvészet címkéje alá be nem sorolható, de a vizualitásra épülő termékek megsokasodásával vált igazán közszájon forgóvá, és csak az utóbbi évtizedekben kezdtünk rá diszciplínaként, kutatási területként tekinteni. Azt azonban nem szabad szem elől tévesztenünk, hogy az emberiséget kialakulása óta jellemzi a vizuális kultúrája! Így aztán a vizuális kultúra kutatás nem korlátozhatja magát kizárólag a kortárs jelenségekre, még akkor sem, ha a legtöbb kihívás e területen éri. Ahogy Martin Jay fogalmaz: a vizuális kultúra tanulmányozása megmutatja, „mennyire széles azon kulturális hatások köre, amelyek behálózzák egy-egy művész alkotását, és hogy ez a háló már korábban is létezett, de csak most, a kölcsönös adaptációnak köszönhetően vált ennyire láthatóvá."142 Szerinte a vizuális kultúra tanulmányozása során jobban megismerhetjük, hogyan lépett interakcióba, és hogyan van a mai napig kapcsolatban a magaskultúra, a nagy mesterek müvészete a nála sokkal hétköznapibb vizuális környezettel. ${ }^{143}$

Herbert 2003-as tanulmányában a vizuális müvészeteken túl kívánja terjeszteni a fogalmat, három szempontból. Az első a „vizuális alkotások közösségének demokratizálása”, mivel „más vizuális alkotások ugyanolyan esztétikai és ideológiai komplexitással bírnak”. Így

\footnotetext{
${ }^{139}$ Mirzoeff, Nicholas: Mi a vizuális kultúra? In: Ex-Symposion, 2000/32-33. szám. Ex-Symposion Alapítvány, Veszprém, 2. old.

${ }^{140}$ Az eredeti mü: Mirzoeff, Nicholas: Introduction: What is Visual Culture? In: Nicholas Mirzoeff (szerk.): Visual Culture Reader. Routledge, London, 1998.

${ }^{141}$ Gombrich, E.H.: The Visual Image. In: Scientific American 1972. szeptember. Magyarul megjelent $A$ látható kép címmel. In: Horányi Özséb (szerk.): Kommunikáció II., Budapest, Közgazdasági és Jogi kiadó, $1978 ., 123$.

142 Dikovskaya, Margaret: Interjú Martin Jay-jel. (2001.02.02.) In: Apertúra, 2013. tél. http://uj.apertura.hu/2013/tel/interju-martin-jay/ (letöltés: 2017.11.06.) ${ }^{143}$ U.o.
} 
bármely vizuális alkotás a tudományos vizsgálódás tárgyává válhat. A második, hogy „kutatási területét nem súlyosan terhelt kulturális fogalmak mentén határozza meg, hanem transzkulturálisan is müködő fiziológiai jellegzetességekre támaszkodva: a világon mindenkinek van szeme, és ezek a szemek képesek a látásra.” A harmadik szempont pedig az, hogy egyfajta dematerializáló jellemzővel is bír, mert vizsgálata eltolódik a „dolgokról a látás folyamata felé” és mert hangsúlyosan kezeli a „képtermelés” nem dologiként megvalósuló változatait, a filmet, a videót, a televíziót és a számítógépes képalkotást. ${ }^{144}$

F. Orosz Sára egy empirikus megközelítéssel, szemléletes példákkal világít rá, milyen széles kört ölelhet fel e fogalom: „Ebbe a művészeten kívül a legegyszerübb hétköznapi, illetve ünnepi tárgyaink is beletartozhatnak; a szappantartó, a fogkefe, a laptop, a Pókember, az óriásplakátok, Marilyn Monroe mosolya, a koronaörök egyenruhája, a katolikus pap miseruhája, vagy a Parlament előtt álló karácsonyfa látványa és jelentése." ${ }^{145}$ E definíció már az ezredforduló utáni világot vetíti elénk. A definiálási nehézségek megvilágításához azonban ismét visszább kell lépnünk az időben.

A vizuális kultúra fogalmának definiálási nehézségei részben abból fakadnak, hogy már eleve a kultúra kifejezés körülírására sincs egységes definíció. Első, ma is gyakran idézett antropológiai meghatározását Edward Burnett Tylor brit antropológus adta 1871-ben: „a kultúra vagy civilizáció, a maga teljes etnográfiai értelmében az az összetett egész, amely magában foglalja a tudást, hiedelmet, müvészetet, törvényt, hagyományt és mindazon egyéb képességeket és szokásokat, amelyekre az embernek, mint a társadalom tagjának szüksége van."146 E definícióból kiindulva később számos megfogalmazás született, (Kroeber és Kluckhohn könyve már 1952-ben 165 definíciót sorol fel ${ }^{147}$, ez a szám azóta több ezerre emelkedett) ám a legtöbb szócikk idézi Tylor felsorolását, annak hatása napjaink közvélekedésére is erőteljesen rányomta a bélyegét. Megpróbálhatunk ezen a nyomon elindulni a vizuális kultúra definícióját keresve. Ez esetben le kell választanunk a felsorolt fogalmak azon aspektusait, amelyek valamilyen kapcsolatban állnak a vizualitással: látás útján nyert tudás, látás útján létrehozható és befogadható művészet, látáshoz kapcsolódó jogok, látványban megtestesülő szokások, látvány és hiedelem viszonyai. A terület így is óriásinak tünik.

\footnotetext{
${ }^{144}$ Herbert, James D.: Vizuális kultúra / Visual Studies. (ford.: Hornyik Sándor) http://meonline.hu/vizualiskultura/vizualis-kultura-visual-studies/ (letöltés: 2018.03.20.)

${ }^{145}$ F. Orosz Sára DLA: Vizuális kommunikáció, esztétika. Egyetemi jegyzet. Gödöllő, 2010.

${ }^{146}$ Tylor, Edward Burnett: A kultúra tudománya. In: Maróti A. (szerk.): Forrásmunkák a kultúra elméletéből, 1. szöveggyüjtemény. Budapest, Tankönyvkiadó, 1989, 167-178.

${ }^{147}$ Kroeber, A. L. and Kuckhohn, C.: Culture. A Critical Review of the Concepts and Definitions. Papers of Peabody Museum of Archeology and Ethnography, 1952.
} 
A Walter Brugger-féle Filozófiai lexikon szerint a XVII.-XVIII. századtól a kultúra kifejezés ,átfogja mindazt, ami az ember tudatos és szabad beavatkozásának köszönheti létrejöttét.” Ugyanakkor megjegyzi, ,a kultúra olyan jellegü kibontakozása, amely az ember lényegével szemben történik, nem valódi kultúra, hanem látszatkultúra. (...) a kultúra olyan alkotómunkát jelent, amely világon belüli célokra irányul. A merőben külső, materiális kultúrát civilizációnak nevezzük." ${ }^{148}$ Felvetődhet tehát az a kérdés, hogy a vizuális kultúra kifejezés értelmezésekor nem kell-e különválasztanunk a kultúra és a civilizáció fogalmát. (Bár napjainkra pontos definiálásuk lehetetlensége folytán mindkettő inkább keretfogalommá ${ }^{149}$ vált.) Oswald Spengler a két fogalom mint jelenségek egymásutánisága mellett érvel, értelmezésében a kultúrában a lélek megvalósítja lehetőségeit, a civilizáció pedig - mivel már mindent megvalósított - ezért csak utánoz, stagnál, majd megindul a hanyatlás, a leépülés. ${ }^{150}$ Ezt az elvet követve arra juthatunk, hogy egy adott időszak társadalmának vizuális kultúrája is egy idő után, önmagán túllépve, szükségszerủen vizuális civilizációvá válik. A spengleri gondolatmenet értelmében a nyugati kultúra már jó ideje civilizációként müködik, tehát egykori látáskultúrája is immáron ilyen dimenzióban értelmezhető: a mai embernek már tulajdonképpen nincs is látáskultúrája, csupán olyan civilizációs vívmányai, amelyek a vizualitáson alapszanak.

A vizuális civilizáció kifejezés nyelvi szempontból kettős értelmet hordozhat, hiszen gondolhatunk egy vizualitásra épülő civilizációra, illetve a civilizáció vizualitásra épülő részére, amelyet próbálnánk elkülöníteni a többi összetevőtől. Korunk tekinthető vizualitásra épülő civilizációnak is, erről tanúskodik például Mario Vargas Llosa A látványcivilizáció ${ }^{151}$ címü könyve, melyben a Nobel-díjas perui író kifejti, hogy szerinte az „,igazi” kultúra - amely még a lét legfontosabb kérdéseivel foglalkozott, s amely nem elandalítani, hanem gyakran felrázni akarta az embert - meghalt, vagy legalábbis haldoklik, és mindent elönt a felszínes látványosság, a light kultúra, a szórakozás. Jelen esetben azonban a vizuális kultúra illetékességi körének kirajzolása a cél, így térjünk vissza a fogalom második értelmezésére, a civilizáció vizualitáson alapuló részéhez. Ha megpróbáljuk a spengleri kultúra/civilizáció fogalompárt a vizuális kultúra és a vizuális civilizáció összevetéséhez használni, óhatatlanul felmerül az a kérdés, hogy a ma keletkező, ember alkotta, látás útján befogadható dolgok köztük a privát- és sajtófotók, a reklám- és marketing-célú képek, a szórakoztató médiatartalmak - már nem sorolhatók be a vizuális kultúra kategóriájába, csupán a vizuális

\footnotetext{
${ }^{148}$ Brugger, Walter: Filozófiai lexikon. Szent István Társulat, Budapest, 2005.

${ }^{149}$ Vitányi Iván: A civilizáció és a kultúra paradigmái. In: Magyar Tudomány. 2002/6. 720.

150 Spengler, Oswald: A Nyugat alkonya. Első kötet. Fordította: Juhász Anikó és Csejtei Dezső. Noran Libro, Budapest, 2011. 57.

${ }^{151}$ Vargas Llosa, Mario: A látványcivilizáció. Európa Kiadó, Budapest, 2014.
} 
civilizáció termékeiként gondolhatunk rájuk? Be kell látnunk, hogy ha az egységes képtudomány megnevezése után kutatunk, e szétválasztás és kategorizálás - noha érezzük a relevanciáját - nem feltétlenül produktív, sőt, messzebb visz a megoldástól. Ezt a kérdést tehát hagyjuk nyitva, és közelítsük meg a dilemmát a várt eredmények felől.

A vizualitással kapcsolatos társadalmi párbeszédre mindenekelőtt azért van szükség, hogy a társadalom vizuális kultúráját árnyaltabbá, gazdagabbá lehessen tenni, színvonalát emelkedésre lehessen bírni. (Amennyiben tulajdoníthatunk neki ilyet, megengedve, hogy a kultúra milyenségének lehetnek minőségi fokozatai.) A vizuális túlingereltség korában nyilvánvalóan szükség van valamiféle vizuális nevelésre, amely segít kiigazodni a dinamikusan változó képi jelrendszerek labirintusában. E tény arra sarkallhat, hogy az említett jelenségeket összefoglalva nevezzük bátran vizuális kultúrának - azzal a megjegyzéssel, hogy egy részük minden bizonnyal csupán valamiféle látszatkultúra vagy a civilizáció által kitermelt entitás. De talán épp a vizuális kultúra mint müveltségi terület feladata lehet az, hogy segítsen rámutatni a különbségekre. Ilyen értelemben persze a vizuális kultúra egy idea, amelynek, mint fogalomnak a használata elsősorban köznevelési, művelődési, oktatási célokat szolgál, és merőben másfajta értékítéleti rendszert követel, mint a tudományos megközelítés, amely már nem tud mit kezdeni például azzal a felosztással, amely megkülönböztet magaskultúrát és tömegkultúrát. A vizuális nevelésnek viszont központi problémája az a jelenség, hogy napjaink ember alkotta vizuális képtárgyai között igen sok az értéktelen, a pillanatnak szóló, a hulladék, a giccs. Ezek is a vizuális kultúra részei? Ha így van, akkor eljuthatunk a negatív kultúra fogalmához is, megengedve, hogy a kultúra fogalmába nem csupán valamilyen okfejtés mentén értékesnek titulált megnyilvánulások tartoznak bele, hanem mindenféle ember alkotta dolog. A gondolatmenetből kibomlik az a kérdés is, hogy a kultúra válságával vagy változásával állunke szemben. E régi dilemmák eldöntésére most nem vállalkozhatunk, ám a jelenlétük tudomásul vétele segíthet megérteni, mi gátolja az egységes képtudomány vagy vizuális kultúra(tudomány) körvonalazásának lehetőségeit.

Fontos látni azt is, hogy helytelen szembe állítani a müvészettörténetet a vizuális kultúrával, mint ha egyik valamiféle piedesztálon, a másik pedig a tömeg soraiban lenne azonosítható. Mitchell kissé talán demagóg módon fogalmazza meg, hogy a müvészettörténet „úgy szembesül a vizuális kultúra kutatással, mint saját tudatalattijával, mélyen rejlő és elnyomott önmagával, amely (Narcissus képéhez hasonlóan) egyszerre halálos és vonzó."152 Véleményét azonban nem mindenki osztja. Horst Bredekamp szerint a művészettörténet igenis

\footnotetext{
${ }^{152}$ Mitchell, W.J.T: Interdiszciplinaritás és vizuális kultúra. In: Magyar Építőművészet, http://meonline.hu/vizualis-kultura/interdiszciplinaritas-es-vizualis-kultura-kutatas/ (letöltés: 2017.10.10.)
} 
túlmutat a képek világának egészére. Úgy véli, ,,a művészettörténet képtudományként való felfogása szemmel láthatólag tudatos felejtés tárgya." ${ }^{153}$ Bredekamp rámutat a területen tapasztalható zavar egyik lehetséges okára: mivel a német Bild szó jelentése átfogja mindazt, amit angolul az image, picture, figure vagy az illustration szó jelöl, a Bildwissenschaft terminusnak nincs angol nyelvű megfelelője! A Bildwissenschaft fő elemeinek létrejöttét ő az 1900 körüli Ausztriában és Németországban véli felfedezni. „Az 1970-es években viszont a német művészettörténet nagy horderejü megújulása a képtudomány felelevenítésével fonódott össze, s a szakma bevett vizsgálódási tárgyává lett a reklám, a fotó, a tömeges nem művészi fényképezés, a film, a videó és a politikai ikonográfia. Amint megteremtődtek a digitális és a hálózati művészet művelésének feltételei, a művészettörténet ezt is szinte nyomban bevonta a maga tárgykörébe." ${ }^{154}$ - írja Bredekamp, aki tehát korántsem ró fel annyi hiányosságot a müvészettörténetnek, mint Mitchell.

A médiatudományról és a filmelméletről azonban egyértelmübben kijelenthetjük, hogy viszonylag könnyen nyitott és nyit a vizuális kultúra felé, hiszen széles az érintkezési felület: napjainkban a mozgókép és a média közvetítette képek alakítják legnyilvánvalóbban a vizuális kultúrát. És megemlíthetjük még az irodalomtudományt és a szemiotikát is, hiszen verbalitás és vizualitás viszonya, illetve a különböző jelrendszerek és a nyelvi müködés is számos megvizsgálandó kérdést rejt. Mitchell erre is érzékletes hasonlatot szolgáltat: „A vizuális kultúra a külső határvidék s egyben a belső 'fekete lyuk' a verbális kultúra szívében."155

Megközelíthetjük a vizuális kultúra fogalmát a tárgyai, bennefoglaltjai felől is. A vizuális kultúra ily módon megközelítve két főbb halmazt foglal magába: a müvészi ambíciókkal létrehozott alkotásokat, vagyis a tulajdonképpeni vizuális művészetet és a nem művészi szándékkal létrehozott alkotásokat, melyek összefoglaló megnevezése máig problémás - noha már Aby Warburgot is foglalkoztatták. A Mnemosyne címü képatlasztában ${ }^{156}$ a szépművészeti alkotások mellé felsorakoztatta a populáris kultúra és a reklámok termékeit, a tudományos illusztrációkat és a média képeit is. ${ }^{157}$ Bredekamp és Brons úgy vélik, Warburg a nem művészi képeket olyan ,érzékszerveknek” tekintette, amelyek sokkal inkább felfogják a kortársak belső és külső életéből érkező ingereket mint a műalkotások. Szerintük a hamburgi müvészettörténész „a képtudományként értett müvészettörténet lényegét fogalmazta meg

\footnotetext{
153 Bredekamp, Horst: Mellözött hagyomány? A müvészettörténet mint képtudomány. Ford.: Wessely Anna, BUKSZ, 2003/3. 253. 
akkor, amikor e projekt során egy látszólag banális újságlapot ugyanolyan komolyan vett, mint egy Raffaello-freskót, a képtudomány ugyanis azzal az igénnyel lép fel, hogy korlátlan értelmezési energiákat tartson fenn a látszólag marginális és értéktelen számára is."158

Nem kétséges, hogy utóbbiak számára is fenn kell tartanunk az értelmezési energiákat, ám az értelmezés során óhatatlanul fel fog merülni, és egyúttal komoly nehézségbe fog ütközni annak megítélése, hogy napjaink ember generálta vizuális jelenségeiből mi tartozhat a (szép)müvészet kategóriájába? Anélkül, hogy itt arra a lehetetlen feladatra vállalkoznánk, hogy eldöntsük az emberiséggel egyidős vitát - ti. hogy miben áll a müvészet és mi tartozik bele és túlságosan elkanyarodnánk vizsgálatunk eredeti tárgyától, kénytelenek vagyunk letenni a voksunkat valamely általánosan elfogadott, tankönyvi nézet mellé. Induljunk ki az alkotó, az entitást létrehozó személy vagy csoport szándékaiból, és fogadjuk el azt a - talán képlékeny, általánosító és sok felől támadható - meghatározást, mely szerint a vizuális művészet tárgykörébe tartoznak az alkotás és önkifejezés vágyától motivált, a művész saját látásmódjával áthatni kívánt, látás útján befogadható alkotások. Ebböl következik, hogy a nem ilyen célokkal, hanem a dokumentálás, archiválás, informálás, tájékoztatás, ismeretterjesztés, figyelemfelkeltés, szórakoztatás, meggyőzés, szemléletformálás, propaganda, stb. céloktól vezérelve létrejövő, látás útján befogadható tárgyak a vizuális kultúra egyéb halmazaiba tartoznak. Ezek lehetnek kézzel foghatók, anyagiak és virtuálisak, bitekből felépülők. Maga a vizuális kultúra azonban nem csak a látható tárgyak/dolgok/képek sokaságát, csoportját jelenti, ahogyan a kultúra sem csupán létrejövő és létező anyagi javak halmaza. Meghatározásunkat tehát ki kell bővítenünk az azokhoz kapcsolódó tudással, képességekkel, szabályokkal, szokásokkal.

Összegezve: A vizuális kultúra fogalmába beletartoznak a látás útján befogadható müvészeti alkotások, valamint az ember generálta, anyagi vagy virtuális tárgyak és jelenségek azon sokasága, melyek célja lehet a dokumentálás, archiválás, informálás, tájékoztatás, ismeretterjesztés, figyelemfelkeltés, szórakoztatás, meggyőzés, szemléletformálás vagy a propaganda, továbbá a mindezekhez kapcsolódó tudás, képességek, hagyományok, szabályok és szokások - függetlenül attól, hogy ezek mennyire tekinthetők értéknek.

És most térjünk vissza ahhoz a problémához, hogy miként tehetjük nyilvánvalóvá, hogy közlendőnket a vizuális kultúrának arra a részére vonatkoztatjuk, amelynek nincs köze a müvészethez? Napjainkban egy jelentés-eltolódás is megfigyelhető, hiszen sokan a vizuális

\footnotetext{
${ }^{158}$ Bredekamp, Horst - Brons, Franziska: A fotográfia mint tudományos médium. A müvészettörténet, a biológia és az illusztráció nyomorúsága. In: Nagy Edina (szerk.): A kép a médiamüvészet korában. L'Harmattan, Budapest, 2006. 149.
} 
kultúra kifejezést kimondottan erre a halmazra használják, megkülönböztetve vizuális kultúrát és vizuális müvészetet. Ez a szemlélet azonban félreértésekre adhat okot, zavarhoz vezethet. Jelenleg ugyanis úgy tünik, nincs bevett és elfogadott, közismert kifejezés a vizuális kultúrába tartozó azon jelenségek jelölésére, amelyek nem sorolhatók be a művészet kategóriájába. Egy részüket besorolhatjuk a média halmazába. Ez esetben a médiának azon részéről van tehát szó, amely a látáson alapul, a látás révén fogadható be, és elsősorban nem verbális, hanem képi nyelvet használ. Az álló és mozgóképek közvetítésén alapuló médiajelenségeket nevezhetjük vizuális médiának. (A média fogalmának értelmezési lehetőségeivel egy későbbi fejezet foglalkozik.)

Ha a vizuális kultúrát tekintjük a legnagyobb, befoglaló halmaznak, akkor azon belül körvonalazható a vizuális művészet halmaza, amely talán felosztható képző- és iparművészetre valamint filmmüvészetre. Megrajzolhatjuk a vizuális média halmazát is, amely egy kis területen fedheti a művészet halmazát is, hiszen létezik „médiamüvészet” is, amely nem azonos a filmművészettel. És marad még néhány halmazunk, amelyek mindig is részét képezték a vizuális kultúrának: öltözködéskultúra, lakáskultúra, tárgykultúra, térkultúra - metszésben az iparművészettel. Ha a fentieket egy ábrán próbálnánk összegezni, az így festene:

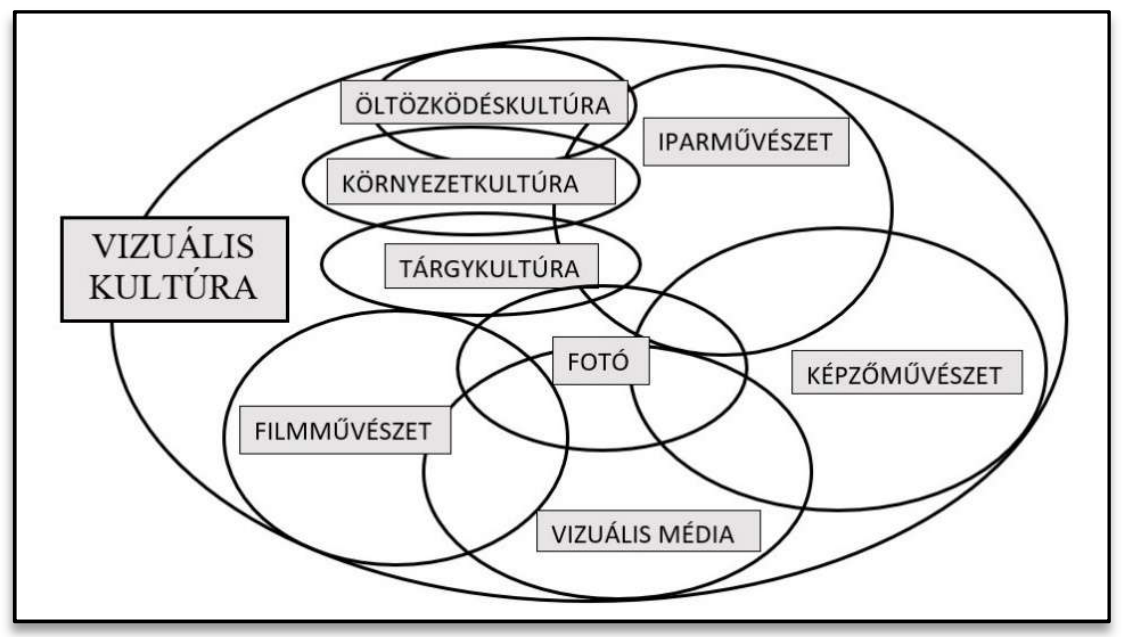

Az így megrajzolt - sok szempontból természetesen vitatható - térképen kell mozogniuk mindazoknak, akik a látvánnyal vagy a képekkel kívánnak foglalkozni - amennyiben elfogadjuk, hogy a vizuális kultúra lehet az a címke vagy hívószó, amelybe mindenféle, ember alkotta kép beletartozik. Ám arról sem szabad megfeledkeznünk, hogy amint a kultúra sem azonos a kultúratudománnyal, és a művészet sem azonos a művészetelmélettel, úgy a vizuális kultúrára sem szabad tudományként tekintenünk. Sokan használják az iménti elvet követve a 
vizuális kultúratudomány ${ }^{159}$ kifejezést, ám ebbe beletartozik a fenti ábrán értelemszerűen nem jelölhető, a halmazokhoz tartozó tudás, képességek, hagyományok, történetek, gondolkodásmódok, elméletek, szabályok és szokások összessége is, melyek vizsgálata megintcsak az interdiszciplinaritás szükségességét vetíti elő.

\section{I.3.2. A több diszciplínát igénybe vevő megközelítés létjogosultsága}

„Mindazonáltal ott van a rutin vagy a rituálé rögzülése előtti pillanat, a káosz vagy a csoda pillanata, amikor egy diszciplína, a dolgok egy bizonyos intézésének módja, kényszeredetten feltárja saját maga alkalmatlanságát. (...) Az ,anarchia” pillanata, amely a tudás populáris, professzionális és ezoterikus formáiban egyaránt érvényesülhet." 160

W.J.T. Mitchell

Nem egyértelmü tehát a válasz arra, hogy a vizuális kultúra mint tudományterületi megnevezés, és egy ahhoz kapcsolódó egységes módszertan lehet-e a megoldás a képekkel való tudományos foglalatosság kérdésére. Egyelőre inkább az látszik járható útnak, ha megmarad a lehetősége a különféle irányultságú megközelítéseknek, és a kutatók változatos módszerekkel próbálnak több irányból válaszokat találni a képek térnyerésével kapcsolatos aktuális kérdésekre.

Mivel a XXI. század elején az emberéletet meghatározzák a képek, alapvető fontosságú, hogy megfelelő minőségü tudományos diskurzus folyhasson e tényről és mindarról, ami ebből következik. Ember és kép viszonyának vizsgálata kapcsán a tudományterületek nem mutogathatnak egymásra, és nem is szigetelődhetnek el egymástól. Azt láthattuk, hogy a kronologikus, stíluselméleti alapállású művészettörténet a modern müvészetek színrelépésétől már nem tud válaszokat adni a képekkel kapcsolatban felmerülő kérdésekre. A lefedetlen területekre vonatkozóan a Bildwissenschaft, a Visual Studies, a Visual Culture, az Iconology megnevezések mind használatban vannak, bár egyik fogalom sincs egyértelmű keretek közé szorítva, de mindegyikre jellemző, hogy müvelöi a művészetelméleten/történeten kívül más tudományágakra is támaszkodnak. Idehaza a vizuális kultúra kifejezés elterjedt, de azt gyakorta

\footnotetext{
${ }^{159}$ Mitchell például a vizuális kultúra kutatás kifejezést használja, melyet úgy definiál, mint a vizuális praxis társadalmi konstrukciójának tanulmányozását. Lásd: Mitchell, W.J.T: Interdisciplinarity and Visual Culture. Art Bulletin, 77. évf., 4. sz., 1995. 540-544. Magyarul: Interdiszciplinaritás és vizuális kultúra. In: Magyar Építőmüvészet, http://meonline.hu/vizualis-kultura/interdiszciplinaritas-es-vizualis-kultura-kutatas/ (letöltés: 2017.10.10.)

${ }^{160}$ Mitchell, W.J.T: Interdiszciplinaritás és vizuális kultúra. In: Magyar Építőmüvészet, http://meonline.hu/vizualis-kultura/interdiszciplinaritas-es-vizualis-kultura-kutatas/ (letöltés: 2017.10.10.)
} 
mint müveltségi területet szokás említeni. Találkozhatunk a vizuális kultúratudomány kifejezéssel is, és még ritkán, de egyre gyakrabban a képtudomány ${ }^{161}$ megnevezéssel.

Érdemes azonban odafigyelni azokra az álláspontokra is, melyek szerint nem feltétlenül kell mindent egy egységes képtudományba beleerőltetni. Martin Jay szerint szükséges a párbeszéd a művészettörténet és a vizuális kultúra között. Ám szerinte: „,mindkettő hasznot húz a másikból, és szükségtelen feltételezni egy olyan, mindenek felett álló diszciplínát, amely egységes módszertannal rendelkezik, és a maga égisze alatt egyesíti a kettőt."162

Az egységes képtudomány lehetősége mellett felvetődhet az interdiszciplináris, a multidiszciplináris és transzdiszciplináris megközelítés lehetősége is. Az interdiszciplinaritás jelen esetben azt jelentené, hogy több tudományterület közé beékelve teremtünk egy új területet. James Elkins figyelmeztet: az interdiszciplinaritás, amelyet a „vizuális tanulmányok” magukról terjesztenek, „többnyire csak mítosz”. Még nem született meg a vizuális tudásnak az az új formája, amely több volna, mint az egyes részdiszciplínák képiségének puszta egymás mellé állítása. ${ }^{163}$ Kiindulópontnak azonban talán ez is jobb, mint a párbeszéd nélkülözése. Egy multidiszciplináris megközelítés ötvözheti több tudomány eredményeit, amennyiben talál egy releváns, meghatározott nézőpontot, amelyből ezt megteheti. Illetve lehet létjogosultsága egy transzdiszciplináris megközelítésnek is, amely számos területről merít, és átjárhatóságot biztosít azok között. Megadhatjuk akár annak a lehetőségét is, hogy a vizualitás lesz az apró részterületekre töredezett tudományos világ lingua francája, amely közös fórumot teremthet a különféle területekről érkezőknek. Ha az egyre bővülő, egységes kanonizáció felé egyelőre nem igazán mutató szakirodalmat tekintjük, akkor ez korántsem lehetetlen.

A különféle tudományágak képekkel kapcsolatos érintkezési pontjai közül, a területén napjainkban zajló aktivitás okán talán érdemes külön kiemelni a képfilozófia fogalmát is, amely bizonyos értelemben a kezdetektől, vagy legalábbis Platóntól fogva létező területe a filozófiának, ám e konkrét kifejezés használata az elmúlt fél évszázadban vált gyakorivá, és napjainkra, a képi fordulat perspektívájának kibontakozásával összefüggésben látszik igazán megerősödni. A kortárs képfilozófiáról elmondható, hogy szívesen tekint ki a különféle diszciplínák irányába, melyek tárgyának, a komplex értelemben vett képeknek a megközelítését

\footnotetext{
${ }^{161}$ Érdekesség, hogy 2011 óta létezik magyar nyelvű „Képtudomány” Wikipédia-cikk - szerző és hivatkozások nélkül - amely leginkább a képfogalom definiálásával foglalkozik, számos vitatható megállapítást téve. https://hu.wikipedia.org/wiki/K\%C3\%A9ptudom\%C3\%A1ny (letöltés: 2017.12.04.)

${ }^{162}$ Dikovskaya, Margaret: Interjú Martin Jay-jel. (2001.02.02.) In: Apertúra, 2013. tél. http://uj.apertura.hu/2013/tel/interju-martin-jay/ (letöltés: 2017.11.06.)

${ }^{163}$ Elkins, James: Visual Practices Across the University. (A vizualitás egyetemet átívelö gyakorlata), Wilhelm Fink, München, 2007. Idézi: Nyíri Kristóf: Vizuális hazatérés - a neveléstudomány képi fordulata. In: Digitális pedagógia 2.0. Budapesti Müszaki és Gazdaságtudományi Egyetem, Typotex Kiadó. http://www.tankonyvtar.hu/hu/tartalom/tamop412A/2011-0023_DP/index.html (letöltés: 2017.08.16.)
} 
segítik. A kortárs képfilozófia nyitottnak mutatkozik a különféle perspektívák iránt, melyekből a képek vizsgálhatók. Így a képfilozófia megnevezéssel illethető tudományterületnek a jelentősége a képek mindennapokban betöltött jelentőségének fokozódásával együtt várhatóan tovább fog növekedni.

A több diszciplínát és a különféle perspektívákat ötvöző megközelítés kétség kívül számos veszélyt rejt magában. Az elnagyolt, felületes problémafelvetések, a részproblémák nem eléggé mélyre ható vizsgálata, vagy a részkérdésekben mutatott tájékozatlanság teljesen félrevezetheti az elmélészt - s ezeket a buktatókat tovább mélyítheti az a tény, hogy tárgyát aktuális jelenségek (is) képezik, melyek átlátásához nincs még meg a megfelelő történelmi távlat. Így aztán rendkívül merész vállalkozás a képekkel kapcsolatos, aktuálisan tapasztalható jelenségekkel átfogóan foglalkozni, mert nem csak az egyes részterületek szakavatott művelői cáfolhatnak rá a kutatóra, de az idő is, amennyiben egy-egy jelenség mégsem a prognosztizálható irányba fut ki. A csapdák sorozata még ezzel sem ér véget, hiszen a kultúrkritikai megközelítés könnyen csábíthat egyrészt a közhelyek, másrészt a változások feletti busongás, valamint a vészterhes jóslatok irányába - márpedig a változástényezők és a válságtünetek összemosása semmiképp nem teszi lehetővé az objektív megnyilvánulásokat.

Ennek ellenére minden bizonnyal érdemes vállalni ezeket a kísérleteket, hiszen úgy tünik, - és ez a fejezet elején olvasható Bredekamp-idézetben is tükröződik - eljárt az idő azon opció felett, hogy a képekhez egyetlen tudományterület részterületén mozogva közelítsünk, hiszen valamennyi tudományágban egyre inkább előtérbe kerülnek a képek. Ahogyan az előzőekben bemutatott teóriákból kiderül: napjaink képdömpingjében ez az opció már nem látszik járható útnak, és egyre több gondolkodó teszi le a voksát egy újfajta módon értelmezett képtudomány, képfilozófia, képértelmezés mellett. Ezeket pedig áthatja az a szellemiség, amely a képi fordulat modellje körül alakult ki.

\section{I.3.3. Mire kötelez a képi fordulat?}

A képi fordulat mint modell egyfelöl reflektál Richard Rorty nyelvi fordulat ${ }^{164}$ terminológiájára, másfelől elhatárolódik tőle és szembehelyezkedik vele. Nagyjából egyidőben, a '90-es évek elején alkotja meg Mitchell a maga pictorial turn-jét, ${ }^{165}$ és Gottfried Boehm az

\footnotetext{
${ }^{164}$ Rorty, Richard (szerk.): The Linguistic Turn: Recent Essays in Philosophical Method. Chicago and London, The University of Chicago Press, 1967.

${ }^{165}$ Mitchell, W.J.T.: Pictorial turn. Artforum, 1992.
} 
iconic turn/ ikonische Wende ${ }^{166}$ fogalmát. E fordulat-modell körvonalazásában meghatározó szerepe volt Martin Jaynek is, aki a képekben és a képekről való gondolkodást igyekezett jogaiba visszahelyezni, és bírálta a XX. századi francia filozófiát, melyet véleménye szerint a képektől való félelem és a látás diszkreditálására való törekvés irányított Henri Bergsontól Jacques Derridáig. ${ }^{167}$ (Az ikonofóbia, azaz a képgyülölet és az ikonoklazmus mint modern képrombolás fogalmai Mitchell és Boehm írásaiban is többször felbukkannak.)

Mitchell és Boehm nézetei, a pictorial turn és az iconic turn között jól tetten érhető a francia hagyományokhoz - Deleuze, Althusser, Derrida - inkább kapcsolódó (és azokkal olykor vitába szálló) amerikai és az európai, fenomenológiai-hermeneutikai tradíciókból táplálkozó szemlélet különbsége. Bacsó Béla értelmezése szerint előbbi azt a kérdést járja körbe, hogy mit akar a kép, utóbbi pedig arra keresi a választ, hogy hogyan hoznak létre értelmet a képek. ${ }^{168}$ Ám mindkettő valamilyen módon reflektál a nyelvi fordulatra, illetve ahhoz képest vagy annak nyomán körvonalazza a maga fordulatát. Hornyik Sándor szerint Boehm Rorty lingvisztikai fordulatán belül artikulálja a maga ikonikus fordulatát, amikor „a Logosz és a textualitás birodalmán belül hangsúlyozta a képek és a metaforák dominanciáját" és amellett érvel, hogy „tulajdonítsunk végre nagyobb jelentőséget az ismeretelméletünket meghatározó képiségnek."169

Ebben a fordulat-modellben foghatók össze a különféle irányultságú képkutatások, amelyeket a XX. század végi, XXI. század eleji információáramlás képi meghatározottsága inspirál. A képi fordulatnak nincs meghatározott programja, pontosan megadható definíciója sincs. Maga Mitchell is úgy fogalmaz: nem válasz semmire, csupán a kérdésfeltevés egy módja. Ugyanakkor nyilvánvalóvá teszi, hogy semmiképp nem egy fajta visszatérésről van szó „a reprezentációról alkotott naiv elméletekhez az utánzásról, a másolásról vagy a megfeleltethetőségről, és nem is a képi »jelenlét« egy megújult metafizikája. Sokkal inkább a kép posztnyelvészeti, posztszemiotikai felfedezése". ${ }^{170}$ Annak felismerését helyezi a középpontba, hogy „bár a képi reprezentáció problémája mindig is velünk volt, most már elkerülhetetlenül sürget, mégpedig példátlan erővel a kultúra minden szintjén, a

\footnotetext{
${ }^{166}$ Boehm, Gottfried: Die Wiederkehr der Bilder. In: Boehm, Gottfried: Was ist ein Bild? München, Wilhelm Fink Verlag, 1994.

167 Jay, Martin: Downcast Eye: The Denigration of Vision in Twentieth-Century French Thought, Berkeley - Los Angeles - London, 1993.

${ }_{168}$ Bacsó Béla: A kép-tudomány margójára. In: Studia Litteraria: Kép, látvány, szöveg. 2013/1-2. LII. évfolyam, 14-15.old

169 Hornyik Sándor: A képi fordulatról. A müncheni Iconic Turn rendezvénysorozat előadásainak margójára. http://exindex.hu/print.php?page=3\&id=420 (letöltés: 2018.05.06.)

${ }^{170}$ Mitchell, W.J.T.: A képi fordulat. (Ford.: Tóth Zsófia Anna) In: Szőnyi György Endre, Szauter Dóra: A képek politikája. W.J.T. Mitchell válogatott írásai. Jate Press, Szeged, 2012. 136.
} 
legkifinomultabb filozófiai spekulációktól kezdve a tömegmédia legközönségesebb alkotásaiig."

E definiálatlanságból adódik, hogy a jelenségnek átfogó, érdemi kritikája sincs, ám mind több és több kutatót, gondolkodót ihlet meg, akik ennek szellemében veszik sorra a képekhez kapcsolódó problémaköröket, illetve gazdagítják meglátásaikkal. Ahogy Bredekamp fogalmaz: „A turn nem valami meghatározott érékre utal, amelyet, mint egy csavart, egyre mélyebben fúrunk a problémák fájának deszkájába, sokkal inkább egy csendes vízben forgó pálcára hasonlít, amely a teljes vízfelszínt motorikájának hatása alá vonja.”171

Az ikonikus vagy képi fordulat tehát új szemléletet hozott a képkutatásba, amely nem ad konkrét programot, de megköveteli, hogy ne csupán szemlélői és regisztrálói legyünk azoknak az aktuális folyamatoknak, amelyek a képek sokasodását, jelentőségük fokozódását hozzák magukkal, hanem értelmezzük is a képeket - egyfelől mint autonóm entitásokat, másfelől mint társadalmi produktumokat és a társadalomra visszaható konstitúciókat. A képi fordulat kötelezi a kutatót arra, hogy megkísérelje felfejteni a képek logikáját, müködésük jellemzőit. Egy rugalmas, a tudományterületek határai által meg nem kötött, nyitott hozzáállást igényel, amely képes elrugaszkodni a történeti beágyazottságtól, de akár a művészet fogalmától is.

A képi fordulat mint szemléleti forma azonban tágassága, komplexitása okán szilárd támpontokat aligha kínál a vizsgálódásokhoz. Így mindenképp célszerü egy-egy konkrét képformát, területet, vizsgálódási irányvonalat kijelölni, amelyet vezetőszálként használva érdemi felismerésekhez juthatunk - anélkül, hogy a rugalmasság és a kitekintés igénye elveszne.

\section{A fejezet összegzése: A képek mint egy vizuális portfólió elemei}

Ahhoz, hogy a képek - mint egy táguló vizuális portfólió elemei - megragadhatók legyenek, szükségesnek éreztem áttekinteni, hogy az olyan alapfogalmak, mint a tapasztalás, a látás, a szemlélő és a kép milyen jelentősebb gondolatokat és nézőpontokat indukáltak a szakirodalomban. Ezek közül a továbbiakra nézve fontos kiindulópont az, hogy a látás nem csupán érzéki, hanem értelmi, konstruktív, intencionális tevékenység, és Arnheim szavaival élve: a részletek keltette benyomások összege sosem lesz egyenlő a teljes kép nyújtotta benyomással. A továbbiakban Gombrich nyomán előfeltételezem azt is, hogy a látás

\footnotetext{
${ }^{171}$ Bredekamp, Horst: Fordulópontok. Az iconic turn ismertetőjegyei és igényei. In: Nagy Edina (szerk.): A kép a médiamüvészet korában. L'Harmattan, 2006. 13.
} 
determinált, nincs elfogulatlan szem, és a szem nem csupán érzékel, hanem maga is létrehoz. A kép fogalmába ebből következően beleérthetőek a mentális képek is, megengedve azt, hogy utóbbiak valamiféle dinamikus, változékony természettel bírnak. Fontosnak tartom azonban a kép és képmás megkülönböztetését, és azt, hogy a kép szó használatakor tegyük világossá, milyen képekről beszélünk, hiszen Mitchell nyomán alkalmas kiindulópontnak gondolom azt a felfogást, hogy a képekhez egy nagy, szerteágazó családfa ágaiként tekintsünk.

Munkám további részében a képre nem csupán önmagában létező alkotásként tekintek, hanem olyan jelenségként, amelynek célja, feladata van, amely tudást és ismereteket hordoz, kommunikál, és amelyre egy adott társadalom produktumaként is lehet tekinteni. A képek elsősorban nem esztétikai megközelítésben érdekelnek, inkább azon aspektusuk lényeges a számomra, amely kulturális hordozóként teszi őket értelmezhetővé, és elmond valamit keletkezési közegükről. Nem csupán a képek tartalma, de a képekre adott társadalmi válaszok, a képekhez való hozzáállás, ember és kép viszonya, a képek gondolkodást meghatározó szerepe áll vizsgálódásom homlokterében, amely a képfilozófiai hagyományokból igyekszik kiindulni.

A képek hatalmas családjából kutatásom középpontjában a továbbiakban a fizikai, azon belül a technikai képek fognak állni. A fizikai természetű képek csoportjába minden, fizikailag létrejövő képet beleértek, az ember alkotta képeken túl a spontán, természeti jelenségek által létrehozott képeket is - mint például az árnykép vagy a tükröződés. Utóbbiak viszont nem értendők bele a technikai képekbe, melyek csoportját az ember alkotta képekre vonatkoztatom.

Míg a képeket korábban a befogadóra intellektuálisan ható, tapasztalatokat konstruáló és rekonstruáló struktúrákként, de alapvetően magukba záródó tárgyakként kezelte a kutatás (elsősorban a müvészettörténet), addig ma inkább „olyan dolgokként kell tekintenünk rájuk, amelyek befogadóik életformáját, értékrendjét, világlátását, azaz egymáshoz és a világhoz való viszonyait alakítják ki és át." - írja Horányi Attila, hozzátéve, hogy a kutatásként felfogott vizuális kultúra feladata éppen ezért e viszonyok müködésmódjának, e viszonyokban résztvevő ágensek - emberek és képek - sajátosságainak és e viszonyok eredményeinek vizsgálata. ${ }^{172}$

A fizikai képek csoportjából leginkább a fényképek azok, amelyeknek vizsgálata közelebb vihet témámhoz, az egyéni életutakat leképező vizuális portfóliók értelmezési lehetőségeihez. E portfóliók aktuálisan tekintve digitális, tehát tiszta információkként létező fotókat tartalmaznak leginkább, noha ezek összevetése a tárgyként létező fotográfiákkal fontos adalékként szolgál majd a képi dokumentációképzés mértékének soha nem látott növekedése mögött álló célok és motivációk feltérképezéséhez. Vizsgálódásaim ugyanakkor elsősorban a

\footnotetext{
${ }^{172}$ Horányi Attila: Vizuális kultúra: dilemmák és feladatok. http://meonline.hu/vizualis-kultura/vizualis-kulturadilemmak-es-feladatok/ (letöltés: 2018.01.11.)
} 
Mitchell által posztfotografikusnak nevezett időszakhoz (Post-Photographic Era) köthetők. (Mitchell a fotográfia korszakát lezártnak tekinti a digitális fotó és a bárki számára elérhető, fotómanipulálást lehetővé tevő programok piaci bevezetésével. Onnantól ugyanis a jel és a leképezendő tárgy közötti megfeleltethetőség már nem egyértelmü.) ${ }^{173}$

A digitális fotók csoportját még tovább szükítem, hiszen a vizsgálódásom homlokterében álló portfóliók mindenekelött privát célú fotókat tartalmaznak. Elengedhetetlen azonban a kitekintés a professzionális, nyilvánosságnak szánt fotókra, amennyiben - mint azt látni fogjuk - elmosódóban van a határvonal a két csoport között. Időnként pedig párhuzamot fogok vonni a mozgóképes anyagokkal, videókkal is, hiszen a portfólióknak ezek is egyre inkább elmaradhatatlan részei, és létrehozásuk mögött sokszor ugyanazok a késztetések és szükségletek állnak.

Bán András 2008-ban azt írta: „a fotográfiáról nincs már mit mondani. A fotográfia megközelítéséről, használatáról, társadalomtörténetéről annál többet”"174 Tasnádi Róbert pedig úgy véli, a sokszorosítással terjedő kép a kultúra terjedésének jellegzetes példájaként is értelmezhető. A társadalmi és közösségi formák létrehozzák saját kommunikatív szférájukat, jelrendszerüket, vizuális kifejezési módjaikat, és ezek valamilyen módon tükrözik a fennálló társadalmi viszonyokat, amelyekből adott esetben következtethetünk bizonyos funkciókra, társadalmi szerepekre, hiedelmekre, érték-orientációkra, végső soron a kultúrára. ${ }^{175}$

Kutatásomban a továbbiakban a fentiek jegyében megfogant, 'kép mint megismerés' alapállású képfogalommal lépek tovább, feladatként tekintve, hogy vizsgálódásaimban még részletesebben ki kell térnem azokra a specifikumokra, amelyeket a kép digitális fotóként való létezése megkíván.

Az alapfogalmak megközelítési lehetőségeinek áttekintésén túl az I. fejezetnek témája volt az az illetékességi vita, amely arról szól, hogy a képek vizsgálata mely tudományterületek feladata lehet. Mint láttuk, e vita egyik iránya az, hogy létre kell jönnie egy egységes képtudománynak, amely önálló módszertant alakít ki. A másik irány pedig több módszertant, többféle megközelítést is megenged, és nem tartja szükségszerünek, hogy önálló területként szilárduljon meg a képek tudománya. Inkább a több diszciplínára való együttes támaszkodást, az azok közötti párbeszédet, az eredmények megosztását preferálja.

\footnotetext{
${ }^{173}$ Mitchell, W.J.T.: The Reconfigured Eye. Visual Truth in the Post-Photographic Era. MIT Press, Boston, 1992.

${ }^{174}$ Bán András: A vizuális antropológia felé. Typotex, Budapest, 2008. 8.

175 Tasnádi Róbert: Miről szólnak a képek? In: Médiakutató, 2012 tél.

http://www.mediakutato.hu/cikk/2012_04_tel/08_mirol_szolnak_a_kepek (Letöltés: 2018.01.11.)
} 
Az I. fejezetben idézett gondolkodók tudományterületek átjárására biztató gondolatai nyomán a továbbiakban használatos képzeletbeli koordináta-rendszerem egyik dimenzióját a tudományterületek: kultúrfilozófia, müvészetfilozófia, müvészettörténet, médiaelmélet, médiapszichológia alkotják, a másikat pedig a tünetek: a kényszeres vizuális dokumentációképzés, a vizuális infláció, a virtualitás, a vizuális nyelv zavarai, a médiamanipuláció és a médiaagresszió. A harmadik kiterjedés pedig a vizsgált problémaköröket vonultatja fel: tapasztalat, reprezentáció, kommunikáció, emlékezet, nyomhagyás, szabadság, identitás. Úgy vélem, csak egy ilyen tágas koordináta-rendszerben, a képi fordulat által megkívánt szemlélettel összhangban vizsgálható meg kellő alapossággal az, hogy napjaink emberének a vizuális dokumentáció meghatározottságában milyen esélyei lehetnek önmaga és világa megismerésére. 


\section{A képekbe kapaszkodó ember}

„Az emberiség javithatatlanul ott lödörög Platón barlangjában, s ösi szokásához híven ma is az igazság puszta képeiben leli legnagyobb örömét." 176

Susan Sontag

Napjaink embere technikai képek által meghatározott életet él: e képek elválaszthatatlanok a mindennapjaitól, meghatározzák az emlékeit, a gondolkodását, a világról alkotott elképzeléseit és az identitását. A képek életünkben való állandó jelenléte, kéznél-levése, és folyamatos igénybevételük egy újfajta létmódot eredményezett: a képekbe kapaszkodó ember létmódját, vagyis egyfajta meghatározottságot, amelyben a képek tartanak bennünket.

A következőkben annak áttekintésére vállalkozom, hogy ezen létmód hogyan alakult ki, milyen folyamatok révén jutottunk el ide, milyen jelentős állomásai lehettek ennek az útnak. Az időbeli áttekintés után - korunkig eljutva - a tüneteket szeretném számba venni, amelyek alátámaszthatják a fenti feltevést. Ahhoz, hogy ezt jobban meg tudjam világítani, kiválasztok egy konkrét tünetegyüttest, és azt alaposabb vizsgálatnak vetem alá: az emberi arc leképezésének megváltozását, az arcképhez való viszonyulás átalakulását, az emberi arc devalválódásának folyamatát tekintem át.

\section{II.1. A technikai képek általi meghatározottság kialakulásának folyamata}

„A látás (...) nyilvánvalóan természetadta képességként van számon tartva. Súlyos tévedés ez, annál is inkább, minthogy a vizuális megkülönböztetés képességére az optikai médiumok korában égetöbb szükség lenne, mint valaha." 177

Gottfried Boehm

Vilém Flusser A fotográfia filozófiája címü, 1983-as esszéjében ${ }^{178}$ nem csupán az ember és a kép viszonyának megváltozásáról ír, de hipotézise azt a gyanút is tartalmazza, hogy a kultúra és egyúttal maga a lét - kezdi alapvetően megváltoztatni a struktúráját a technikai kép

\footnotetext{
${ }^{176}$ Sontag, Susan: A fényképezésről. Európa Könyvkiadó, Debrecen, 1981. 9.

177 Boehm, Gottfried: Mü és észlelés. A klasszikus modernség múzeumában. In: Gottfried Boehm: Paul Cézanne: Montagne Sainte-Victoire - Válogatott müvészeti írások. (Szerk.: Bacsó Béla) Kijárat Kiadó, 2005. 108.

${ }^{178}$ Flusser, Vilém: Für Eine Philosophie der Fotografie (European Photography), Göttingen, 1983.
} 
térnyerésével. Ö a technikai képeket faktumokká rejtjelezett fogalmaknak tekinti, és a csatornák révén kiárasztott fotók elkészülésének automatizmusában, valamint a fotóapparátus általi meghatározottságban látja a változás generátorát. ${ }^{179}$

A fotózás feltalálása kétségtelenül óriási jelentőségü, megkerülhetetlen fordulópont az emberi kultúra történetében, és kiindulópontját adhatja az emberi életet folyamatosan leképező vizuális dokumentálás folyamatának. Ám a kiindulópont meghatározásánál nem a felszínen észlelhető technikai aktusok az érdekesek, sokkal inkább a felfedezéshez vezető folyamat, a mögötte álló motivációs tényezők, a gondolkodásban és attitüdökben bekövetkező változások. Érdemes ezekből kiindulva megvizsgálni, hogyan alakult ki a technikai képek általi meghatározottság állapota, a flusser-i fotóuniverzum, amelyben a világot a fotók funkciójában éljük meg, ismerjük meg és értékeljük.

\section{II.1.1. Változások kép és ember viszonyában}

„Az ösember arca a pocsolyában, az egyiptomiaké a réztükörben csak pillanatnyi szemlélésre alkalmas, csak jelenideje van. Az általa születö vágy viszont filozófiai töltetü: váljon ketté az én az idöben, $s$ a jelenlegi birtokolhassa egykori önmagát, legyen összehasonlitási alapja tegnapi és mai énje között, sőt, képmásokkal igazolhassa maga és családja örökkévalóságát." 180

Kolta Magdolna

A fizikai képek a kezdetektől igen fontos szerepet játszottak az ember életében. Az első ilyen, amellyel az ember találkozott, a saját tükörképe volt, amelyet a víz felszínén észlelt. Nem tudhatjuk, mikor jött el az a pillanat, amikor ősünkben tudatosult, hogy önmagát látja - minden bizonnyal még bőven az emberré válás elött. Azt viszont tudjuk, hogy sok állat felismeri önmagát a tükörben: vegyük alapul Gordon Gallup Jr. 1970-es kísérletét ${ }^{181}$, aki álmukban pirosra festette a csimpánzok szemöldökét - később, amikor meglátták magukat a tükörben, azonnal a szemük fölé nyúltak. A későbbi, szarkákkal, delfinekkel, elefántokkal, stb. elvégzett tükörtesztek $^{182}$ is olyan eredményekkel zárultak, amelyek új megvilágításba helyezték mindazt,

\footnotetext{
${ }^{179}$ Flusser, Vilém: A fotográfia filozófiája. Tartóshullám - Belvedere - ELTE BTK, Budapest, 1990. 39.

${ }^{180}$ Kolta Magdolna - Töry Klára: A fotográfia története. DFM, Budapest, 2007. 12.

${ }^{181}$ Gallup, G. G., Jr.: Chimpanzees: Self Recognition. Science/167, 1970. 86-87.

${ }^{182}$ A '70-es évek óta számos, az állatok tükörrel kapcsolatos viselkedését dokumentáló kísérlet zajlott és számos tanulmány született. Lásd pl.: Helmut Prior: Mirror-Induced Behavior in the Magpie (Pica pica): Evidence of Self-Recognition. PLoS Biology. http://journals.plos.org/plosbiology/article/file?id=10.1371/journal.pbio.0060202\&type=printable (letöltés: 2018.01.12.)
} 
amit az állatok öntudatáról gondoltunk. Bár a tükör-tesztekkel kapcsolatban sokféle kritika ${ }^{183}$ is megfogalmazódott, az mindenesetre kijelenthető, hogy önmagunk külső, fizikai képen való észlelése, az e képhez való viszony sokat elárul rólunk.

A fizikai képek tudatos létrehozása azonban már emberi specifikum. Noha a történelem folyamán számos festő, rajzoló állat (csimpánzok, lovak, elefántok) „alkotásait” tálalták szenzációként a közönség elé, ezek minden bizonnyal egy betanított viselkedés, és a mellettük lévő ember elvárásainak való megfelelés eredményei, hiszen a természetben nem találunk rá példát, hogy egy állat önszántából és tudatosan fizikai képek létrehozásába kezdjen.

A legkorábbi, ismert fizikai képek a barlangrajzok, melyek között feltételezhetően 2730 ezer évesnél régebbi is akad. A sokáig legelfogadottabb elmélet szerint a vadászmágiát szolgálták, vagyis azzal próbálták biztosítani a vadászat sikerét, hogy a lerajzolt állatot képletesen megölték. Az elmélet az 1960-as évektől árnyaltabbá vált: ${ }^{184}$ a barlangrajzok minden bizonnyal egy, a jégkorszak embere számára ismert mítosz illusztrációi lehettek, és a nem lakott, de tömegek által látogatott barlangok teret adtak különböző mágikus és felnőtté avatási szertartásoknak. Az utóbbi megközelítés méginkább alátámasztja, hogy a fizikai kép már ekkor igen fontos szerepet játszott az identitásképzésben. Nem csupán az önkifejezésben (ha ez egyáltalán cél volt), hanem fordított irányban is, hiszen a rajzok megléte, megtekintése, mítikus értelmezése és az esetleges szertartásos felhasználás visszahatott a barlangba lépő, vagy a rajzokat emlékezetében elraktározó emberre, alakítva annak önmagáról és közösségéről alkotott képét, világszemléletét.

A barlangrajzokkal kapcsolatban ma létező tudást többnyire „az őskor müvészete” címszavak alatt ismeri meg napjaink embere, noha itt is felmerül az előző fejezetben már feltárt probléma: praktikusan a mủvészettörténet (és természetesen a régészet) hatáskörébe tartoztak, holott talán inkább egy átfogóbb képelméleti megközelítésben, többféle nézőpontot is beengedő, kevésbé leszűkítő értelmezésben lennének jobban megismerhetők. Nem feltétlenül célravezető elsődlegesen müalkotásként értelmezni őket, ám a vizuális kultúra mérföldköveiként betöltött szerepük vitathatatlan. Érdemes lehet például az ember és a kép viszonytörténetének kiindulópontjaként tekinteni rájuk, egy olyan út kezdőállomásaként, amely

\footnotetext{
${ }^{183}$ Gyakori kritika, hogy a teszt „embercentrikus”, olyan magatartást vár el az állatoktól, ami az emberekre jellemzö. Nem számol azzal, hogy az állatok másképp használják érzékszerveiket, illetve azzal sem, hogy bizonyos fajokat nem érdekel a tükör. Kiderült az, is hogy sokszor még a 6 éves gyerekek sem mennek át a teszten.

${ }^{184}$ A korábbi elképzeléseket leginkább a Lascaux-i barlang részletes feltérképezése, elemzése helyezte némiképp más megvilágításba. Lásd: Annette Laming: La Signification de l'art rupestre paléolithique. Éditions A. \& J. Picard, 1962.
} 
elvezet addig a szoros, már-már a függés szóval is jellemezhető, heteronóm viszonyig ${ }^{185}$, amely ma fennáll ember és kép között. Nem véletlen, hogy Walter Benjamin is ezektől indítja gondolatmenetét, felhívva a figyelmet annak jelentőségére, hogy bár az ott ábrázoltakat a kőkorszaki ember „embertársai előtt állítja ki, elsősorban mégis a szellemeknek szánja”186 _ tehát a kultikus érték még a műalkotás elrejtésére szolgál, a kép értékét a rituálé alapozza meg, és az is tartja magában egészen a reprodukálhatóság lehetőségéig, Benjamin szerint.

Ha az őskor emberalkotta képeivel megkezdve a sort végigtekintünk a fizikai képek történetén, a rituális, szakrális, misztikus és mítikus célok, a transzcendens hatalmak szolgálatának és megidézésének vágya mellett még számos motivációs tényezőt sorra vehetünk, amelyek e történet tárgyai mögött regisztrálhatók. Ilyen tényezö a fontos események megörökítésének vágya, a közösségi emlékezet táplálása, a feledés megakadályozása - e funkciót egy későbbi fejezetben, az emlékezet kapcsán részletesen is elemzem majd. A fizikai képek létrehozásának katalizátorai között megtaláljuk a dicsőség és a hatalom kinyilvánításának, a hódolat megszerzésének vágyát, valamint a történetmesélés vagy valamilyen tanítás átadásának vágyát (pl. Biblia pauperum), majd ezekre ráépül a gyönyörködtetés, a megrázás vagy az önkifejezés igénye. A célok függvényében változott a technika és az ábrázolásmód, váltották egymást az egyediséget és az általánost előtérbe helyező korszakok, a láthatóhoz való hasonlatosságot és a láthatatlan lényeget megragadó, a transzcendens felé tekintő és a természeti valóságra figyelő, illetve a dekorativitást vagy épp a puritanizmust preferáló érák.

Bármi legyen is a motiváció, a történelem során a fizikai kép mindig egyfajta tiszteletet, áhítatot váltott $\mathrm{ki}$, és ez az, ami napjainkra gyökeresen megváltozott, hiszen a kép mindennapossá, megszokottá, hétköznapivá vált. A változás nem egyik pillanatról a másikra következett be, de kétség kívül ahhoz kapcsolható, amikor a gép, a technikai apparátus belépett a fizikai képek elkészülésének folyamatába. E pillanatól kezdve a fizikai képek halmazán belül sokasodásnak indultak a technikai képek. Walter Benjamin emögött az aura elveszítését látja, illetve úgy véli, ,azzal, hogy technikai reprodukálhatóságának korszaka eloldotta kultikus alapjától a művészetet, autonómiájának fénye örökre kihunyt.”187

\footnotetext{
${ }^{185}$ Flusser a kábítószer-függőséghez hasonlítja a fotóst, aki gépe nélkül már vaknak érzi magát, fotómánia hajtja, amely redundáns képeket eredményez. Lásd: Flusser, Vilém: A fotográfia filozófiája. Tartóshullám - Belvedere ELTE BTK, Budapest, 1990. 48.

${ }^{186}$ Benjamin, Walter: A müalkotás a technikai reprodukálhatóság korában (ford.: Kurucz Andrea, Mélyi József). http://aura.c3.hu/walter_benjamin.html (letöltés: 2018.02.02.)

${ }^{187}$ Benjamin, Walter: A müalkotás a technikai reprodukálhatóság korában (ford.: Kurucz Andrea, Mélyi József). VII. rész. http://aura.c3.hu/walter_benjamin.html (letöltés: 2018.02.02.)
} 
Benjamin ugyan a mủvészetre vonatkoztatja gondolatmenetét, de tágabban értelmezve az is elmondható, hogy a képekhez való viszonyban változott meg valami végérvényesen, amikor a technikai tényező szerepe az emberi tényező szerepét elkezdte meghaladni. Ám ennek ellenére nem volna helyes, ha csupán a gépeket hibáztatnánk azért, hogy napjaink embere már nem tapasztalhatja meg azt a letaglózó élményt, amely például a középkori embert érte, amikor betért egy templomba és megpillantott egy oltárképet. Fontos látni azt a szellemi átalakulást, amely csillapíthatatlanná tette a valóság pontos dokumentálása iránti igényt, és szükségszerüen a fotográfia feltalálásához vezetett. Emögött ott van a megfigyelő pozíciójának megváltozása, amelyre Jonathan Crary felhívja a figyelmet, és amely elméletre az előző fejezet részletesen kitért. Ugyanakkor egy új látásrendszer csíráit többen felfedezni vélik jóval a fényképezés felfedezése elött, köztük Peter Galassi, ${ }^{188}$ Svetlana Alpers ${ }^{189}$ vagy Martin Jay.

Martin Jay a modernitás látásrendszereit elemezve megkülönbözteti az uralkodó, karteziánus perspektívát, amely elbeszélő jellegű, és egy határozottan pozicionált nézőt feltételez, az északi művészetre - főként a XVII. századi holland festészetre - jellemző, leíró jellegű perspektívától, ahol a néző pozíciója ingatagabb. Úgy véli, ha ennek van filozófiai megfelelője, akkor „,az nem a geometrizált, racionalizált, lényegében intellektuális térfelfogással rendelkező kartezianizmus, hanem inkább a megfigyelésre összpontosító baconi empirizmus sokkal kézzelfoghatóbb látástapasztalata."190 Jay ezzel regisztrál egy alternatív látásrendszert, amely leíró jellegével megelőlegezi a fényképészet XIX. századi feltalálása által létrejövő vizuális tapasztalatot. A domináns modellen belüli belső zavar második pillanatának pedig a barokkot tekinti Jay, amely mint „,a látás őrülete”191, korunknak szintén sok mindenben megfeleltethető.

A XIX. század elején azonban már kétségbevonhatatlanul feltámad az igény a puszta valóság-másolatokra, a müvészi ambíció nélküli, dokumentáló jellegü képekre. A képek mitológiai és teológiai mondanivalója háttérbe szorul, és fontosabbá válik a valóságot legteljesebben megközelítő ábrázolás nem-szubjektív rögzítése. Kolta Magdolna egyenesen úgy fogalmaz: „muszáj” volt felfedezni a fotográfiát és a filmet: „Daguerre, Niépce vagy a Lumiére fivérek nem tehettek mást, mint engedték, hogy bennük, személyükön, tudásukon

\footnotetext{
${ }^{188}$ Galassi, Peter: Before Photography: Painting and the Invention of Photography, New York: Musem of Modern Art, 1981.

189 Alpers, Svetlana: The Art of Describing: Dutch Art in the Seventeenth Century. The University of Chicago Press, 1983.

190 Jay, Martin: A modernitás látásrendszerei. In: Hal Foster (szerk.): Vision and Visuality. Bay Press, Seattle, 1988. 3-29. (Ford.: Végső Roland) A fordítás forrása: http://www.c3.hu/scripta/vulgo/2/1-2/jay.htm (letöltés: 2017.11.11.)

${ }^{191}$ Martin Jay Lessingre és Christine Buci-Glucksmann: La raison baroque: de Baudelaire á Benjamin címü mủvére hivatkozva használja a kifejezést.
} 
keresztül fókuszálódjon mindazon ismeret, akarat, vágy, ami a világban addig a pillanatig összegyült." 192

A technika fejlődésének meglódulása, a technológia és a gépek iránti tisztelet tehát szükségszerüvé tette, hogy a camera obscura képét meg is lehessen ragadni, be lehessen égetni, örökkévalóvá lehessen tenni. Az igény megjelenésével egyidejüleg, egymástól függetlenül többen ${ }^{193}$ is megoldották ezt a problémát. A találmány visszhangjából kiderül, hogy a legtöbbeket az nyügözte le, hogy kiiktatható az emberi tényező: „Soha a legnagyobb művészek rajza sem teremte hasonlóbbat. (...) Itt nem az emberek gyarló tekintete többé, melly a gyönge szem előtt az árnyat vagy a fényt felmutatja; nem azok reszkető keze többé, mely egy mozgékony papírra a világ változó napjait utánozza." 194 - írta Jules Janin múkritikus 1839-ben, a találmány bejelentésekor. Tudjuk, hogy a hazai lapok is gyorsan hírt adtak a vegyi úton történő képírás megvalósulásáról. Bólyai Farkast például az eljárás objektivitásáról faggatták. „Még azt a kérdést is feltették, hogy Daguerre találmánya vajon eredeti színeiben adja-e vissza a világ valódi képét." ${ }^{195}$ - lelkendezett a matematikus. Erre természetesen még jó ideig várni kellett, de ebből is látható, hogy éppen annak a hiánya tünt vonzónak, ami az emberi közremüködés révén kerül a képbe/képre. Jól tükrözi a közvélekedést a talbotípia megalkotójának, Henry Fox Talbotnak a megfogalmazása: a fotográfiákat ,a Természet keze hozza létre." ${ }^{196} \mathrm{Az}$ általa kifejlesztett pozitív-negatív eljárás történetét és eredményeit bemutató, 1844-es albumnak is ezt a címet adta: The pencil of Nature. A természettudományos fotográfia úttörője, Joseph von Gerlach pedig 1863-ban kijelentette: a fényképezés a tárgy tévedhetetlen önreprezentációját jelenti. ${ }^{197}$

Az út hamarosan kettéágazott: az egyik utat járók megmaradtak ennél a célnál, amely a puszta látvány, az egyéni életutak és közösségek egyes pillanatainak megőrzésén túl egybefonódott a tudomány, a tömegkommunikáció, a média, a reklám és a public relations céljaival. Az ezen célok jegyében született képek célja a dokumentálás, a tudás átörökítése, a megőrzés, az archiválás, a közkinccsé-tétel, a bemutatás. Ugyanakkor itt találjuk meg a csíráit annak a jelenségnek, amely napjainkra az egyén mérték nélküli képi dokumentáció-képzésébe

\footnotetext{
192 Kolta Magdolna - Tőry Klára: A fotográfia története. DFM, Budapest, 2007. 12.

${ }^{193}$ Heinrich Schulze német vegyész a 18. század elején felfedezte az ezüstsók fényérzékenységét. Louis Daguerre és Nicéphore Niépce kifejlesztették a dagerrotípiát, majd jött a talbotípia, illetve a nedves kollódiumos eljárás és az albuminpapír párosa, később a celluloid.

${ }^{194}$ L'Artiste, 2 s., II, 145-148. Idézi: Szilágyi Gábor: Daguerre. A fényképezés felfedezésének története. Gondolat Kiadó, Budapest, 1987. 119.

${ }^{195}$ Szimán Oszkár: A szines fényképezés alapjai. Müszaki Könyvkiadó, Budapest, 1985. 9.

196 Talbot, Henry Fox: A természet irónja. (ford.: László Ágota, Enyedi-Prediger Éva) Hogyf Editio, Budapest, 1994.

${ }^{197}$ Gerlach, Joseph: Die Photographie als Hülfsmittel mikroskopischer Forschung. Leipzig, 1863.
} 
torkollt. A másik út pedig egy új müvészeti ág, a fotóművészet kifejlődéséhez vezetett. (A fotómüvészet termékeinek célja pedig ugyanúgy ragadható meg, mint bármely másik müvészeti ág alkotásaié.) Közben a rögzített állókép megmozdult, s a mozgókép fejlödéstörténetében ugyanez a kettéágazás figyelhető meg: az eljárást egyaránt használja a média és filmművészet, csak más-más célokkal.

Ha a képek általi meghatározottság mint kortünet kerül szóba, természetesen senki nem a vizuális müvészeti alkotások hatómezejének erőteljesebbé válására gondol, sőt. Ahogy a vizuális kultúra-definíciók körbejárásánál láttuk, sokkal inkább a halmaz másik része duzzad mind hatalmasabbra. Ám ennek vizsgálatához mégis fontos látni, mi történt a képzőművészettel, amelyet alapjaiban rengetett meg az a tény, hogy a látható valóság leképezésének már nem a festészet vagy a grafika a kizárólagos eszközei. A fotográfia hatása alól nem tudták kivonni magukat a festők sem: voltak, akik megpróbáltak versenyre kelni vele, mások $^{198}$ újabb eszközt láttak benne - mint a reneszánsz festők a camera obscurában. Az impresszionista festők és szellemi örököseik azonban valami olyasmit szerettek volna nyújtani, amit a fotográfia sosem tud: az érzéki benyomásokat, a látvány keltette hangulatokat vitték vászonra vagy papírra, egyre kevésbé törődve a dolgok valósághű körvonalaival és anyagiságával. Megindult a forrongás, újabb és újabb irányzatok születtek. Bizonyos nézőpontból tekintve az ezerarcúvá váló képzőművészet bámulatos virágzásnak indult, más szemszögből szemlélve azonban válságba jutott, hiszen elérkezett végső kereteiig, melyeket már nincs hová feszíteni. Piszoár mint műalkotás (Marcel Duchamp) ${ }^{199}$, egyszínű vászon (Yves Klein) ${ }^{200}$ üres képkeret a falon (Andy Warhol) ${ }^{201}$ stb. - Hová tovább, mủvészet? - tették fel a kérdést sokan, és teszik fel azóta is újra meg újra: lásd a korábban már érintett művészet végekoncepciókat.

A fényképezés széleskörü elterjedése óta azonban eltelt egy bő évszázad. Ezalatt - ha nem is állíthatjuk biztosan, hogy a képzőmüvészet megtalálta a helyét - mindenesetre az alkotók hozzászoktak ahhoz az állapothoz, hogy a valóság leképezését nem tőlük várja a társadalom. Müvészi alkotások pedig ennek tudatában is születnek, mennyiségük sem esett vissza, épp ellenkezőleg. Más kérdés, hogy hatásuk volumene a müvészettörténet korábbi korszakaiban készült alkotásokéhoz viszonyítva elenyésző, de ez nem csupán abból fakad, hogy

\footnotetext{
${ }^{198}$ Munkácsy Mihály, aki fotótanulmányokat készített többek között a híres Krisztus-trilógiájához, hogy azok segítségével még érzékletesebben tudja megfesteni a szenvedő testet.

${ }^{199}$ Duchamp, Marcel: Fountain (Az alkotás címe magyar fordításban mint „Forrás” terjedt el, más forrásokban „Szökökút”-ként emlegetik.) A keletkezés éve 1916 vagy 1917.

${ }^{200}$ Yves Klein 1955-ben kezdi festeni monokróm képeit, pl. IKB 191 - Monokróm kék.

201 Andy Warhol már befutott művészként azzal sokkolta a közvéleményt, hogy üres képkereteket állított ki, mondván, hogy a hozzá nem értő sznoboknak úgysem tűnik majd fel.
} 
kevésbé akadnának közöttük korszakalkotó müvek, hanem éppen a vizuális kultúra egyéb halmazainak felduzzadásából, a képiség mindennapossá válásából.

Itt meg kell vizsgálnunk egy látszólagos ellentmondást. Ha egy-egy kép ma sokkal jelentéktelenebb hatást gyakorol a szemlélőre, mint a gépi képalkotás előtti időkben, akkor hogyan beszélhetünk mégis képek általi meghatározottságról? Hiszen az oltárkép előtt áhítatba eső őseink számára a kép sokkal meghatározóbb élményt nyújtott! Az ellentmondás azonban rögtön feloldhatóvá válik, ha különbséget teszünk a kép nyújtotta élmény általi meghatározottság és a képek általi meghatározottság között. Egykor valóban nyújthatott életre szóló, fundamentális élményt egy-egy kép. Ma viszont nem a képben rejlő vagy a kép mögötti tartalmak tartják determinatív viszonyban a szemlélőt, hanem maguk a képek - mint a tapasztalatszerzés, a megismerés, a szórakozás és a kommunikáció empirikus valóság helyébe lépő egységei. Képekre váltottuk a hétköznapi valóságot, ezáltal a kép is hétköznapi lett, és e hétköznapi minőségében vált szükségletté.

Roland Barthes szerint a fénykép nem képes túlmutatni egy deiktikus, rámutató nyelvezeten, a „nézd”, „itt van”, „ez az” élményén: „egy fényképet nem lehet filozófiai értelemben (úgymond) transzformálni, teljes egészében annak az esetlegességnek a ballasztja terheli, amelyet áttetszőn, könnyedén körülölel." ${ }^{202}$ Barthes nyomatékosítja, hogy míg minden más fizikai kép valamilyen módon különbözik attól, amit ábrázol (hiszen az, hogy a tárgyát utánozza, törvényszerüen rajta hagyja a bélyegét), a fénykép nem különbözik töle, természeténél fogva tautologikus. Emellett mindig láthatatlan: bármit és bárhogyan mutat, a szemlélő sohasem a fényképet látja, hanem annak tárgyát, az ábrázolt összenő a fényképpel.

Azzal kapcsolatban, hogy mikor mit látok - képet vagy azt, ami a képen van - különféle elméletek láttak napvilágot. A reprezentációnak megfelelő látás tekintetében Gombrich úgy véli, nincs kettős percepció, nem lehetek egyszerre tudatában a médiumnak és a reprezentáció tárgyának. Richard Wollheim azonban vitába száll ezzel: szerinte, ha reprezentációt mint reprezentációt nézek, akkor „nem csupán megengedett, de egyenesen követelmény, hogy egyidejüleg figyeljek a tárgyra és a médiumra."203 Megkülönbözteti a valamiként látás kategóriáját, amely annyit jelent, hogy x-et y-ként látom, ám szerinte a reprezentációs látás inkább a benne látás kategóriájával írható le, vagyis y-t látjuk x-ben. Wollheim szerint az, hogy egy fényképet nézve kit vagy mit látunk helyesen, nagymértékben azon múlik, hogy „kihez vagy mihez kapcsolódtak megfelelő módon a fényképezőgép megvalósította kauzális

\footnotetext{
${ }^{202}$ Barthes, Roland: Világoskamra. Európa Könyvkiadó, Budapest, 1985., 9.

${ }^{203}$ Wollheim, Richard: Valamiként-látás, benne-látás és a képi reprezentáció. In: Bacsó Béla (szerk.): Kép, fenomén, valóság. Kijárat Kiadó, 1997. 233.
} 
folyamatok, s ezzel tökéletesen egybevág, hogy a fényképek esetében nem áll fenn az a festményeknél releváns megkülönböztetés, amelyet a modell és az ábrázolt személy között teszünk." 204 Ez azonban csak a fényképnek megfelelö látásra vonatkozik, nem pedig arra az esetre, amikor a fényképet mint fényképet próbáljuk megfigyelni.

E megállapításokat a mozgóképre is kiterjeszthetjük: amikor híradót nézünk, vagy éppen egy vlogger szórakoztat bennünket, eszünkbe sem jut, hogy képet, képeket látunk hacsak nem azzal a céllal nézzük, hogy mint médiaterméket analizáljuk. A kép képiségének háttérbe szorulása még egyértelmübb, amióta a fotók megszüntek tárgyak lenni, és digitális információhalmazként bármilyen felületen megidézhetők lettek.

A képi meghatározottság kora azzal érkezik el, amikor a képek a mindennapi élet fel sem tủnő velejárói lesznek, amikor elmosódik a különbség a valóságban látott és a képen látott, a valóságban tapasztalt és a média révén érzékelt dolgok között. E jelenséget jól illusztrálja annak az idős hölgynek a példája, aki külföldön élő rokonával videótelefonon beszélt, és másnap megkérdezte a családjától, itt van-e még a rokon, vagy már visszautazott - nem tudatosult benne, hogy az előző napi beszélgetés nem személyes, csupán a webkamera közreműködésének köszönhető élmény volt. De ugyanezt az érzést erősíti az a tény, hogy lépten-nyomon találkozhatunk ún. élőképekkel, vagyis olyan képekkel, amelyek valós időben képként jelenítenek meg egy tőlünk távolabb eső helyszínt például egy webkamera segítségével, vagy amikor a televíziók élő adásban mutatnak be valamit. Ez is olyannyira hétköznapivá vált, hogy napjainkban bárki képes valós idejü eseményközvetítést produkálni egy okostelefon és a közösségi háló segítségével, amit bárki láthat az interneten.

A XX. század végére tehát elérkeztünk ahhoz az állapothoz, amikorra a kép vált a tapasztalatszerzés, az információszerzés, a tudásszerzés és az élményszerzés alapjává. Ebből következik, hogy a kép identitásainkat is talán minden korábbinál erőteljesebben befolyásoló tényezővé lépett elő - bár ahogy láttuk, a képeknek mindig is volt egy identitásszervező szerepe, már az őskori vizuális megnyilvánulások óta. Ám most nem a képtől a szemlélőre visszaható élmény áll e szervezőerő középpontjában, hanem maga a(z empirikus tapasztalat helyére benyomuló) kép. A testetlenné vált, önnön képi mivoltára már nem utaló kép, amelyet nem képként csodálunk, hanem valóságként veszünk róla tudomást. Érdemes vizsgálódásunkat azzal folytatni, miként történhet ez meg, vagyis mi az az új eszköz és platform, amely hozzásegíti az embert ahhoz, hogy a valóságot képre cserélje.

${ }^{204}$ U.o. 230. 


\section{II.1.2. Testetlen és befejezetlen technikai képek egy posztfotografikus időszakban}

Vilém Flusser felhívja a figyelmet arra, hogy a technikai képet ${ }^{205}$ nehéz megfejteni, mégpedig azért, mert minden látszat arra mutat, hogy nem kell megfejteni. Látszólag nem-szimbolikus, objektív karaktere a nézőt arra indítja, hogy ne képnek, hanem ablaknak lássa azt, úgy higgyen neki, mint a saját szemének. Flusser szerint azonban a technikai képek egyáltalán nem ablakok, hanem felületek, amelyek mindent faktumokká alakítanak át, és mint minden kép, ezek is mágikusan hatnak. Ám ezt azért látjuk be nehezebben, mint például egy festmény esetében, mert a kódolás egy black box belsejében, elrejtve történik. A fénykép elkészülését az apparátus és a fotóprogram szolgálja, és a fényképész szándéka sok esetben alárendelődik ennek: „Érdeklődése az apparátusra összpontosul, számára a világ csak ürügy az apparátus lehetőségeinek megvalósítására. Röviden: nem dolgozik, nem a világot akarja megváltoztatni, hanem információkat keres." ${ }^{206}$ Flusser a fotógesztusban egy tipikus posztindusztriális gesztust lát, amely számára „az információ, nem pedig az információ jelentése a valóság”. Megkülönbözteti a fényképészt a knipszelőtől, vagyis a privát fotóstól. A knipszelő „nem a fényképezés »fölött« áll, hanem elnyelte az apparátus mohósága: a fényképezőgép meghosszabbított önkioldójává vált." ${ }^{207}$ Ennek következménye az öntudatlanul előállított képek állandó folyama, melyeket végignézve nem egy ember megörökített élményeit, felismeréseit látjuk, hanem a készülék automatikusan megvalósított lehetőségeit! A knipszelök és dokumentaristák tehát nem információkat, hanem készülék-emlékezetet hoznak létre. Ezzel szemben az experimentális fotográfus tudatosan fáradozik azon, hogy olyasmit hozzon ki az apparátusból és tegyen át képbe, ami nem szerepel a programban. Tudja, hogy az apparátus ellen játszik. ${ }^{208}$

Ha a napjainkban keletkező fotókat áttekintjük, ezt a Flusser által kívánatosnak talált tudatosságot nagyon ritkán fedezhetjük fel - függetlenül attól, hogy hivatásos fotósról, képzett operatőrről (hiszen a mozgóképekre is igazak a fenti megállapítások) vagy amatőrről van-e szó. Ráadásul a demokratizálódó média, az újmédia ${ }^{209}$ világában a hivatásos és amatőr közötti

\footnotetext{
${ }^{205}$ Flusser azt a képet tekinti technikai képnek, amit apparátusok állítanak elő. (Míg más meghatározások szerint minden ember alkotta kép technikai kép).

${ }^{206}$ Flusser, Vilém: A fotográfia filozófiája. Tartóshullám - Belvedere - ELTE BTK, Budapest, 1990. 24.

${ }^{207}$ U.o. 48.

${ }^{208}$ U.o.

${ }^{209}$ Noha az újmédia kifejezés (vagy külön írva: új média) használatos leginkább a második generációs internet és a XXI. századi technikai újítások által fémjelzett, digitális-konvergens világra, figyelemre méltó Bajomi-Lázár Péter észrevétele, mely szerint ezeket „abból a szempontból könnyelműség »újnak« nevezni, hogy a média története voltaképpen másról sem szól, mint arról, miként válnak »új« médiumok »régivé«." Lásd: Bajomi-Lázár Péter: Média és társadalom. Antenna könyvek, PrintXBudavár Zrt. - Médiakutató Alapítvány, 2008. 51.
} 
határvonal egyre inkább elmosódik, hiszen bárki publikálhat fotókat és mozgóképeket a széles nyilvánosság számára. A média tehát megtelt tudatosság nélkül elkészített fotókkal, melyeket Flusser a következő, szándékosan elfogadhatatlannak szánt, provokatív definícióval illet, amely kizárja az embert mint szabad cselekvőt: „egy programozott apparátusok által, véletlenszerüségen alapuló játék során szükségszerüen, automatikusan előállított és terjesztett, mágikus faktumot tartalmazó kép, amelynek szimbólumai a befogadóját valószerütlen viselkedésre informálják." ${ }^{110}$ (Ezért mondja Flusser, hogy a fotográfia filozófiájának az ezzel ellentétes fotográfiai gyakorlatot kell a tudat felszínére hoznia, illetve elgondolkodtatni a szabadság és értelmezés lehetőségeiről egy apparátusok uralta világban.)

A tudatosság, az emberi tényező felszínre hozása az apparátus programjának rovására a fotó mindhárom, hagyományosan felállított kategóriájában kívánatos: a fotóművészetben, a sajtófotó területén és a privát fotók világában is. E kategóriák különbségeiről szólva Bán András úgy véli, a fotóművészet mütárgyai meditációra sarkallják a nézőt, míg a sajtóban megjelenő „fogyasztásra szánt” fotográfia legfeljebb az egyszeri rátekintést igényli. Szerinte a harmadik kategóriába a privát használatú képek tartoznak, a maguk „funkcionális esztétikájával”. ${ }^{211} \mathrm{~A}$ határok azonban nem merevek e három kategória között, hiszen a fotómüvészet legfőbb közvetítője a média, és a privát használatú képek megtekintésébe is mind több és több szemlélő vonódik be a média által, amennyiben azok már nem a könyvespolcra feltett, csak a közeli ismerősöknek megmutatott albumban, hanem a közösségi oldalakon teljesítik be létüket, több száz ember kattintásnyi reakciójára számot tartva. Érdemes tehát részletesebben megvizsgálni azt, hogy a nagy mennyiségü, kritikai gyakorlat nélkülözésével megszülető fotó illetve a mozgókép hatásgyakorlásában milyen szerepet tölt be a közvetítő közeg, a csatorna, a média.

Minden látható kép valamilyen közvetítéssel jut el hozzánk. Egy kép láthatósága a tág értelemben vett médium, a közvetítő sajátságain alapul, amely sajátságok meghatározzák a kép észlelését és megteremtik a néző figyelmét. A hordozó és a medialitás kérdése tehát nem kerülhető meg, amikor a képek befogadásáról beszélünk. A médium lehet maga a forma, de olyan eset is van, amikor a médium közvetíti a formát. ${ }^{212}$ A sajtófotókkal kapcsolatban egyértelmü, hogy azok egy médiafelületen teljesíthetik be küldetésüket, hiszen eleve azzal a céllal készültek, hogy a nyilvánosság elé tárjanak valamit. A müvészi fotóknál is evidensnek vesszük, hogy valamiféle valós vagy virtuális nyilvános térbe kerülnek, hiszen a

\footnotetext{
${ }^{210}$ u.o. 62.

${ }^{211}$ Bán András: A vizuális antropológia felé. Typotex, Budapest, 2008., 19.

212 Belting, Hans: Image, Medium, Body: A New Approach to Iconology, Critical Inquiry. Volume 31., Winter, 2005, 302-319.
} 
mủalkotásoknak ideális esetben befogadóközönsége is van. E két csoportról leginkább azt mondhatjuk el, hogy elemeik mennyisége nő a nyilvános térben. A privátfotók, családi fotók, az egyéni életutakat megörökítő képek esetében azonban új, XXI. századi jelenség az, hogy széles nyilvánosság elé kerülnek, és a média bekapcsolódik a sorsukba. Ehhez azonban először az kellett, hogy testetlenné, tiszta információforrássá váljanak.

A technikai kép hosszú időn át elsősorban képtárgy volt. A fotográfiák is sokáig kézbe vehető, kézzelfogható dolgok voltak - részben még ma is azok, bár egyre növekszik azon fotók száma, amelyeket soha nem nyomtat ki senki. Flusser szerint a fotó, amíg nem elektromágneses, addig összekötő elem az ipari tárgyak és a tiszta információk között. Az archaikus fotókkal még valami dologit, szórólapszerüt tartottunk a kezünkben, ám ez már „,az első lépést jelzi a Dolog értékvesztésének és az információ értékké válásának útján."213 - írja. Ahogy a papírképek helyét átveszik a digitális jelek formájában létező képek, az információ dologi alapja eltünik, és utóbbiakkal már tisztán úgy bánhatunk, mint információforrásokkal.

A digitális kép pixelekre azaz képelemekre bomlik, amelyek sürüsége meghatározza a felbontást. A képelemek tulajdonságait bináris adatokkal, nullák és egyesek sorozatával határozzák meg. A korábbi, kémiai eljáráshoz képest tehát egy újfajta kódolási technikával rendelkeznek. „Míg az analóg technika a valóság bizonyos értelemben közvetlen leképezésén alapszik, addig a digitalizálás eljárásával a képi információ bináris kódja kerül kép és valóság közé.”214 - állapítja meg Lehmann Miklós, aki szerint a digitalizációval a képek olyan tulajdonságokat vesznek fel, melyek sok tekintetben élesen szembeállíthatók a hagyományos képfogalommal.

Tehát míg az analóg képek rendelkeznek egy adott valóságra vonatkozó referenciával, hiszen a fény révén indexikális kapcsolat van leképezett és kép között, a digitális képek kódolási technikája megszünteti ezt a kapcsolatot, így magát a referenciát. Ezért mondta Fred Richtin, hogy a fotós újságírás valós események tanújaként betöltött szerepe ${ }^{215}$, Bernard Stiegler pedig azt, hogy a fotográfia autentikus dokumentumként való értelmezhetősége véget ért. ${ }^{216} \mathrm{E}$ kategorikus kijelentéseknek azonban bírálója is akad: Jens Schröter azzal érvel, hogy a referencia az intermedialitás hatására jön létre, és nem függ olyan médiumspecifikus ontológiai kategóriáktól, mint analóg és digitális. A digitális képeket feldolgozó folyamatok fejlődését

\footnotetext{
${ }^{213}$ Flusser, Vilém: A fotográfia filozófiája. Tartóshullám - Belvedere - ELTE BTK, Budapest, 1990. 42-43.

${ }^{214}$ Lehmann Miklós: A digitális kép. http://lehmann.hu/lm/digitkep.pdf (Letöltés: 2018.01.22.)

${ }^{215}$ Ritchin, Fred: In Our Image: The Coming Revolution in Photography. How Computer Technology is Changing Our View of the World. New York, 1990.

${ }^{216}$ Stiegler, Bernard.: Digitale Photographie als epistemologischer Bruch und historische Wende. In: Engell, L., Neitzel, B. (szerk.): Das Gesicht der Welt. Medien in der digitalen Kultur. München, 2004. 110.
} 
pont a referencialitás növelésének szándéka motiválta. Szerinte a manipulálhatóság nem a referencia ellentéte. ${ }^{217}$

A manipuláció, illetve annak mértéke azonban mégis kulcsfontosságú lehet a képek státuszának megváltozása kapcsán. Az eredeti szándék lehetett a referencia növelése, de mivel lehetővé vált az attól való elszakadás, ez az esetben jó részében meg is történik. A digitális környezet nem csupán nagyobb teret nyújt a korábban is alkalmazott manipulációnak, hanem magát a képfeldolgozást alakította át manipulációvá, így már nem húzható világos határ a képek minőségi javítása és a képek megváltoztatása közé. Lehmann Miklós ebből arra következtet, hogy a digitális képek esetében soha nem beszélhetünk kész képekről, csupán változatokról! ${ }^{218}$

Mitchell is úgy véli, hogy a digitális fényképezés és a Photoshop program piaci bevezetésével a fotográfia korszaka lezárult, és megkezdődött a posztfotografikus időszak (Post-Photographic Era), melytől kezdve az ikonikus, indexikus kapcsolat már nem alkalmazható általánosan, illetve a jel és a leképezendő tárgy közötti megfeleltethetőség már nem egyértelmü. ${ }^{219}$ Ezzel konvergens Lev Manovichnak az az állítása, mely szerint az újmédia egyik alapelve a változtathatóság (a numerikus reprezentáció, a modularitás, az automatizálás és az átkódolás mellett). Ennek értelmében az újmédia objektumai nem egyszer és mindenkorra rögzítettek, hanem potenciálisan végtelen számú változatban létezhetnek. ${ }^{220}$

Mindezek mellett a digitális képekhez való viszonyt meghatározza az a tény is, hogy sokkal egyszerübbé és olcsóbbá vált az előállításuk. Egyfajta kockázatmentesség illúzióját keltik: a képkészítés aktusa bármennyiszer megismételhető, nem korlátozza azt a filmkockák véges száma, az előhívás nehézkessége és anyagi vonzata.

Láthattuk, hogy az egyén világ-dokumentáló és öndokumentáló aktusainak sokasodása már a fotó-tárgyak időszakában, a „,knipszeléssel” megkezdődik. Ám a privátképeket akkor még többnyire családi fotóalbumokban, vagy a szobák falán, bekeretezve őrizték. E képek még nem feltétlenül kerültek kapcsolatba a szük értelemben vett médiával, nem volt az elkészülésük pillanatában nyilvánvaló, hogy készítőjük a nyilvánosság terére szánja őket. Még a digitális fényképezőgépek első hullámának idején is élesen különváltak a magáncélra készített és a publikálni kívánt képek. Előbbiek, ha nem is készült belőlük papírkép, azért általában bekerültek valamiféle virtuális albumba, a családi vagy személyi számítógépek egy-egy, erre a

\footnotetext{
${ }^{217}$ Schröter, Jens: Analóg/Digitális. Referencialitás és intermedialitás. Apertúra, 2012. tavasz http://apertura.hu/2012/tavasz/schroter-analog/digitalis (letöltés: 2018.04.13.)

${ }^{218}$ Lehmann Miklós: A digitális kép. http://lehmann.hu/lm/digitkep.pdf (Letöltés: 2018.01.22.)

${ }^{219}$ Mitchell, W.J.T.: The Reconfigured Eye. Visual Truth in the Post-Photographic Era. MIT Press, Boston, 1992.

220 Manovich, Lev: Az újmédia nyelve: Mi az újmédia? In: Gerencsér Péter (szek.): Új, média, müvészet. Universitas Szeged Kiadó, szatírIKON, Szeged, 2008. 25.
} 
célra fenntartott mappájába. A nagy változást e téren a közösségi oldalak elterjedése hozta, amelyek a kétezres évek elejétől váltak igazán interaktívvá, lehetővé téve a fórumozást, az üzenetküldést, a blogolást - és a képmegosztást! A web2.0 megjelenésével a privátfotó fogalma kezd eltűnni, és folyamatosan halványul a nyilvánosságnak szánt és a magáncélra szánt, a sajtófotók és a privátfotók közötti határvonal, és ugyanez elmondható a mozgóképekröl, videoanyagokról is. (Nem ritka, hogy a tévéhíradók magánszemélyek mozgóképfelvételeit mutatják be, akik épp a közelben tartózkodtak, amikor egy közérdeklődésre számot tartó dolog - baleset, terrortámadás, tüzvész, stb. - történt és megörökítették azt.) Ma már minden knipszelő információközlővé válhat valamely médiafelületen, miközben a hivatásos fotósok, operatőrök oroszlánrésze sem csinál egyebet, mint knipszel - a futószalagon végzett munka és a feletteseik által elvárt, napi képmennyiség prezentálásának kényszeréből adódóan. Alig akad - Flusser szóhasználatával élve - experimentális fotós, aki tudatosan próbálná magát kivonni az apparátus programja alól. (Sőt, újabb apparátusok újabb programjainak vetik alá magukat, attól függően, hogy milyen médiarendszerben publikálnak.) Amatőr és profi között a különbség talán csak annyiban ragadható meg, hogy a hivatásosok tovább tanulják a képkészítés technikáját és nagyobb szakmai hozzáértéssel müvelik. Azt már nem feltétlenül mondhatjuk el, hogy több ember látja munkáikat, hiszen a fénykép- és videomegosztó portálok egyre nagyobb tömegeket érnek el, és egy-egy vlogger olykor nagyobb nézettségre tesz szert, mint valamely globális televíziócsatorna híranyagának készítői. És ez a láthatóvá válás, a látszódás fenntartásának illúziója lehet az egyik motivációs tényező, amely sűrű vizuális dokumentációt sző az egyén életútja köré. Ez készteti arra, hogy a keze újra és újra a kioldógomb körül kalandozzon, redundáns képeket létrehozva.

E dokumentációképzésnek egyik fontos és sokat eláruló tünete a redundancia. A készülő képek újra és újra megörökítik ugyanazt a témát, vagy legalábbis valami nagyon hasonlót, és már egy minimális változás is felgerjeszti az új kép készítésének igényét. Közben pedig a kép egyre szorosabban összeforr a publikálási aktussal, a készítő számára nem csupán a készítés a lényeges, hanem a készités valahova. Aktus és szándék együttesen van jelen, nem csupán készítünk egy képet, hanem készítünk egy képet a használt közösségi oldalra, az internet nyilvánossága számára. Az egyéni életút állomásait őrző vizuális dokumentáció tehát napjainkban elsősorban mediatizált technikai képekből tevődik össze, melyek nem képtárgyként, hanem testetlen képi információként léteznek. 


\section{II.1.3. A mediatizáció szerepe a képek általi meghatározottság kialakulásában}

„Nincs olyan kép, amely közvetítés nélkül jutna el hozzánk” - írja Hans Belting a kép, a médium és a test kapcsolatának elemzése apropóján. ${ }^{221}$ Ha ebből a kijelentésből indulunk ki, akkor minden képet már eleve mediatizáltnak tekinthetünk. Tovább menve Belting megjegyzi, hogy a képekre általában mediális jellemzőikkel együtt emlékezünk: a vásznat a képtől csak akkor látjuk külön, ha egy ilyen, analitikus megfigyelés a célunk. (Mindez egybevág Wollheim már idézet gondolataival.) Ha a vizuális médiumok önmagukra utalnak, akkor épp saját képeiről terelik el a figyelmet. Mégsem haszontalan külön vizsgálni a képek és a hétköznapi értelemben vett média közötti kapcsolat sajátosságait, az ebből fakadó aktuális jelenségeket, illetve azt, hogy a modern tömegmédia miképp hatott a képekre, $\mathrm{s}$ e hatás milyen láncreakciókat indított be. Mindez természetesen Belting törekvéseivel sem ellentétes, hisz ő maga is rámutat: „már nem a művészet, hanem a technológia utánozza az életet."222

Médiatudományos körökben napjainkban egyre inkább elötérbe kerül a médiakommunikációs változások és a szociokulturális változások, társadalmi folyamatok közötti összefüggések kutatása. A mediatizáció (mediatization) ${ }^{223}$ kedvelt fogalmává vált a kommunikációkutatásnak. E kifejezés azt a hosszútávú átalakulásra utaló metafolyamatot kívánja megragadni, amelynek révén a mindennapi gyakorlat, a kapcsolati hálók és a társadalmi viszonyok egyre inkább a médiában való megjelenés és a média-intézmények által alakulnak. ${ }^{224}$ Ilyen értelemben a mediatizáció fogalma nem választható el a vizuális dokumentációképzés aktus-sorozatától.

Ahhoz, hogy a mediatizációnak a képek általi meghatározottság kialakulásában betöltött szerepét vizsgáljuk, először magának a médiának a mibenlétét, vizsgálódásunk szempontjából használható meghatározását kell körvonalaznunk. Ez azonban már önmagában is nehéz feladat, hiszen az értelmezésnek számos síkja, megközelítésmódja létezik. Frédéric Barbier és Catherine Bertho-Lavenir médiatörténeti alapmunkájukban ${ }^{225}$ médiának tekintenek minden olyan kommunikációs rendszert, amely lehetővé teszi, hogy egy társadalom betöltse három

\footnotetext{
${ }^{221}$ Belting, Hans: Kép, médium, test: az ikonológia új megközelitésben. (ford.: Matuska Ágnes) Apertúra, 2008. ősz. http://uj.apertura.hu/2008/osz/belting/ (letöltés: 2018.05.15.)

${ }^{222}$ U.o.

${ }^{223}$ Használatos a medializáció (medialisation) kifejezés is, és a kettő közötti különbségtétel nem egyértelmü a diskurzusokban.

${ }^{224}$ Lásd például Livingstone, Sonia: On the mediation of Everything (Journal of Communication 59/1. 2009. 118.) címü munkáját, vagy Hepp, A. Hajarvard Stig és Lundby: Mediatization: theorizing the interplay between media, culture and society címü tanulmányát. (Media, Culture \& Society 37/2, 2015.)

${ }^{225}$ Barbier, Frédéric - Bertho-Lavenir, Catherine: Histoire des médias, de Diderot à Internet. A. Colin, Coll. U, 1996.
} 
létfontosságú funkcióját: a megőrzést, az üzenetek és a különböző tudásformák távolsági kommunikációját és a különböző politikai és kulturális gyakorlatok reaktualizálását: „,valamit valamilyen formában megőrizni azt jelenti, hogy megteremtjük az információk felhalmozásának lehetőségét, új perspektívába helyezzük őket, és belőlük kiindulva jelentős szellemi munkát végzünk, azaz lehetővé tesszük mind a tudás, mind a tudás kritikájának fejlődését."226 - írják. A távolsági kommunikáció értelmezésükben annyit tesz, hogy „kiszabadulunk a tér- és időbeli meghatározottság béklyóiból, hogy közkinccsé tesszük a tudást,

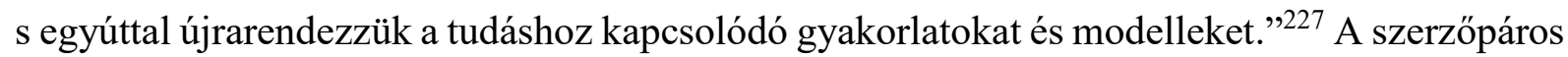
tehát a küldetés felől közelít a média fogalmához, és így ez alá sorolja az egyszerü szóbeli közlést, társalgást is, továbbá minden társadalmilag létrejött kommunikációs struktúrát és ezen struktúrák hordozóit.

Krokovay Zsolt három dimenzióját veszi sorra a fogalomnak. Az első, legtágabb értelmezés szerint a média a mondanivaló kifejezésére használatos közvetítő közegek összessége. Ám úgy véli, amikor általánosságban beszélünk a médiáról, akkor a sajtó, a rádió, a televízió és újabban a világháló kifejezési formáiban létrejött nyilvános fórumok összességét értjük alatta. „Beleértve természetesen a képregényeket és magazinokat, kártyákat és videojátékokat, transzparenseket és óriásplakátokat, ülősztrájkokat és felvonulásokat, kéregetéseket és gyüjtéseket, jelvényeket és kokárdákat, a hosszú hajat és a meztelen napozást, a színdarabokat és filmeket, operákat és operetteket, CD-, DVD- és videórendszereket, papírra vagy trikóra nyomtatott karikatúrákat, rajzokat, fényképeket és feliratokat." ${ }^{228}$ A harmadik, legszűkebb értelmezést pedig úgy adja meg Krokovay, mint a rádiózás és televíziózás müsorszolgáltatásainak összességét és az internetes tartalomszolgáltatást. Úgy véli, a gyakorlatban mindhárom szóhasználat jól felismerhető, baj csak abból származik, ha összekeverjük ezeket.

A képek mediatizációja kapcsán is nagyon fontos e megkülönböztetés. A továbbiakban e jelenség alatt nem a képekkel összetartozó közvetítő forma kiteljesedését értem, inkább azt, ahogy a képek a hagyományos megjelenési formákat elhagyva, vagy éppen azokkal együtt „átköltöznek” a napjainkban meghatározó nyilvános-technikai fórumokra, a különféle képernyőkre. Az ilyen értelemben vett mediatizációval szorosan összefügg az intermedialitás folyamata is, vagyis a médiumok egyfajta rétegződése a képek életében. Gondoljunk itt például arra a jelenségre, amikor a festményt lefotózzák, a fotó belekerül egy nyomtatott

\footnotetext{
${ }^{226}$ Barbier, Frédéric - Bertho-Lavenir, Catherine: A média története. (ford.: Balázs Péter) Osiris kiadó, 2004. 13. 227 U.o

${ }^{228}$ Krokovay Zsolt: Médiaetika. L'Harmattan, 2004. 10.
} 
képzőművészeti albumba, az albumot bemutatják a televízióban, majd a róla készült mozgóképes anyagot felteszik egy videomegosztó csatornára, ahonnan többen megosztják azt valamelyik közösségi oldalon. E többszörös áttételek napjainkban egyre kevésbé szokatlanok, és nem könnyítik meg a képek vizsgálatát, elemezhetőségét, és alátámasztják azt, hogy az intermedialitás vonzásmezőjében létező képek csak a képi/ikonikus fordulat által felkínált új szempontok révén közelíthetők meg. Ahogy Bredekamp rámutat: az iconic turn képlete ,arra szólít fel, hogy minden területen és minden médiumban, ahol álló- vagy mozgóképek jelennek meg, módszertanilag finomítsuk képelemző eszközeinket." ${ }^{229}$

Visszatérve még néhány gondolat erejéig a média fogalmához: ennek megközelítéséhez nyilvánvalóan nem elég azt eldönteni, vajon a szóbeli közlés vagy éppen a bolti kirakat beletartozik-e. Ennél sokkal fontosabb kérdések is megválaszolásra várnak. Például az, hogy e fogalmat szabad-e zárt és autonóm egységnek tekinteni, és lehet-e a médiatermékeket az irodalmi vagy képzőmüvészeti alkotásokhoz hasonló módon elemezni. E kérdésre egyre többen válaszolnak nemmel, amellett érvelve, hogy a média keretfogalom, nem csupán terület, hanem akár eszköz és forma együtt, vagy maga a tartalom létrejöttét indukáló, milyenségét meghatározó erő.

Szemben a torontói iskola technológiai szemléletű megközelítésével és a frankfurti iskola kultúrkritikai, a médiában a nép ópiumát látó megközelítésével, a birminghami iskola a mindennapi használatot és a pragmatikát alapul véve végeláthatatlan áramlásként, folyamatként tekint a médiára, mint a világról való ontológiai gondolkodásunk legalapvetőbb eszközére és produktumára. ${ }^{230}$ Roger Silverstone szerint a média mára a tapasztalat általános szövetének részévé vált. „Gondolhatunk rá úgy, mint egyfajta csőhálózatra, amely nagyjából zavartalan utat biztosít az üzenet és az elme között, felfoghatjuk nyelvként, amely szövegeket és reprezentációkat kínál értelmezésre, vagy tekinthetjük környezetünknek, amely minden irányból körülvesz minket intenzitásával, fojtogat, de egyszersmind kihívásként is müködik."231

Silverstone figyelmeztet bennünket: nincs és nem is lehet egyetlen, átfogó médiaelmélet, ilyet keresni hiba lenne, hiszen lényegéhez tartozik az a komplexitás, amely módszertani szempontból is megkerülhetetlen. Szerinte a médiáról úgy kellene gondolkodni, mint közvetítési folyamatról, azaz mint mediatizációról. ${ }^{232}$ Amennyiben ezt a megközelítést

\footnotetext{
${ }^{229}$ Bredekamp, Horst: Fordulópontok. Az iconic turn ismertetőjegyei és igényei. In: Nagy Edina (szerk.): A kép a médiamüvészet korában. L’Harmattan, 2006. 21.

${ }^{230}$ Császi Lajos: Bevezetés Roger Silverstone: Miért van szükség a média tanulmányozására? c. könyve elé. Akadémiai Kiadó, Budapest, 2008. 10.

${ }^{231}$ Silverstone, Roger: Miért van szükség a média tanulmányozására? Akadémiai Kiadó, Budapest, 2008. 17-18. 232 u.o. 28.
} 
fogadjuk el, akkor az a kérdés, hogy mely dolgok tartoznak bele és melyek nem, jelentőségüket veszítik.

E komplex jelentéshalmazból most vegyük sorra néhány tünetét annak a folyamatnak, melynek során a fizikai kép tárgyi megtestesülését, fizikai kiterjedését lassanként feladva digitalizálódik, és átköltözik a médiatérbe. E folyamat egyik utolsó állomásának tűnik az, amikor a privát fotók legfőbb tárolási helyévé is a közösségi oldalak profiljaihoz tartozó „albumok” válnak. Sőt, a tárolás aktusa egyre kevésbé bír jelentőséggel, már nem megőrizni, eltárolni akarjuk ezeket a képeket, hanem közzétenni. Az már régóta nyilvánvaló, hogy a média tette a képet napi fogyasztási cikké, a média révén alakult ki az az állapot, hogy a képek hiánya jobban feltünik a számunkra, mint a jelenlétük. Ám most a mediatizációba belevonódnak családi képek, az individuális emlékek, és ezáltal talán a szubjektum egy újabb darabja.

Ehhez természetesen szükség volt arra az átalakulásra is, amelyen a média az utóbbi évtizedekben keresztülment: a kapuőrö $\mathrm{k}^{233}$ hatalmának háttérbe szorulása, a média demokratizálódása, az újmédia ${ }^{234}$ kialakulása. Végbe kellett, hogy menjen az a folyamat, amely azt eredményezte, hogy bárkiböl lehet információközlö, és az információk nem egy szük elit irányából tartanak a tömegek felé egy egyirányú folyamat keretében, hanem folyamatosan keringenek a sokszereplős, interaktív, nonlineáris hipermédiában. Az újmédia és a web 2.0 világa az, amely tökéletes terepnek bizonyul a képi meghatározottság mind szorosabbá válásához. Az új médiatérben pedig teljességgel átalakulnak a képekkel szembeni elvárások.

Egyrészt ez az átalakult médiatér megnyílik azon képek irányába, amelyek korábban ki voltak zárva belőle. Míg korábban szinte elképzelhetetlen volt, hogy amatőr, privát fotók vagy házivideók megjelenjenek a nyilvánosság előtt, addig mára bevett szokássá vált, hogy az újságcikkekhez a szereplő saját képeit kérik el, a tévéhíradó pedig tele van a járókelők által rögzített képsorokkal. A kamerás telefonok elterjedése óta sokkal több közérdeklődésre számot tartó eseményt sikerül megörökíteni, hiszen ezeket bárki bármikor beüzemelheti - viszont mire egy híradós stáb az adott helyszínre ér, sok esetben már nincs mit felvenni. Közben a professzionális és a lakossági rögzítő eszközök képminősége közötti különbség is csökken. Mindez hozzájárul ahhoz a már említett jelenséghez, hogy elhalványul a differencia a sajtófotó

\footnotetext{
${ }^{233}$ Kurt Lewin fogalmát David Manning White alkalmazta a médiára, és azokat a hírszerkesztőket értette alatta, akik eldöntik, hogy a beérkező információk közül melyekből lesz újságcikk, és melyek nem jutnak el a nyilvánossághoz. A kapuőr később kulcsfogalommá vált a kommunikációelméletben. Az újmédia kialakulásával azonban csökkent a kapuőrök jelentősége, hiszen általa számos, kis kapu nyílt, és valahol szinte bármely információ utat találhat magának a nyilvánossághoz. Lásd: Horányi Özséb - Szabó Levente: A kommunikáció ágenséről. In: Horányi Özséb (szerk.): A kommunikáció mint participáció. AKI-Typotex, Budapest, 2006. 184. ${ }^{234}$ Lásd: Manovich, Lev: Az újmédia nyelve: Mi az újmédia? In: Gerencsér Péter (szek.): Új, média, müvészet. Universitas Szeged Kiadó, szatírIKON, Szeged, 2008. 12-46.
} 
és az amatőr fotó, a hivatásos operatőr által rögzített mozgóképfelvétel és a telefonnal felvett videó között. Ennek jellemző tünete a vloggerek egyre növekvő népszerüsége, illetve az ún. civil újságírás, vagy az egyszemélyes stábok ${ }^{235}$ müködése. Az összemosódást jól jelzi, hogy az intézményes média már nem verseng az amatőr publicistákkal, hanem inkább igyekszik becsatornázni őket. Számos nagy napilap rendelkezik civil fotóshálózattal, eseti szerződéseket kötnek civil újságírókkal. (Magyarországon az MTI hírügynökség is tett hasonló lépéseket fotók gyüjtésére.) $)^{236}$

Ám nem csak az intézményesült média területén érhető tetten a privát/amatőr fotók és mozgóképek begyürüzése. Ezek legfőbb terepe az újmédia legjellemzőbb csatornája: a közösségi oldal. A felhasználók által generált tartalmak iránt folyamatosan nő az érdeklődés, így amikor a médiában megjelenő képekről beszélünk, szembe kell néznünk azzal a ténnyel: ezek nagyobb részét már a privátfotók alkotják! Ennek következtében az érdeklődés valamelyest lokálisabbá válik, hiszen az ismerős státuszban lévő emberek képeit látjuk a legnagyobb mennyiségben. (Ugyanakkor tematikailag szűkül, hiszen a közösségi oldalak beállításainak köszönhetően az érdeklődésünknek megfelelő témák jelennek meg előttünk.) És ahogy korábban már szóba került: az sem feltétlenül igaz, hogy a nagy, intézményes sajtóorgánumok tanult és megfizetett képkészítőinek produktumait feltétlen nagyobb érdeklődés övezi, mint az amatőrökét. Számos példa mutatja, hogy a terjedési mechanizmusok kiszámíthatatlansága folytán olykor egy amatőr felvétel napok alatt megkerüli a világot, sok milliós kattintásszámra szert téve. A sajtófotó és a privátfotó kategóriáinak szétválasztása tehát egyre nehezebb, hiszen utóbbiak halmaza elnyelni látszik az előbbiekét. A privátfotók, az egyéni életutakat ábrázoló képek, vizuális portfólióink elemei mediatizálódtak olyan értelemben is, hogy a nyilvánosság szférájának részeivé váltak.

Mit jelent a mediatizálódás a képek létmódjára nézvést? A fotográfia képzőművészetre gyakorolt hatásai kapcsán már láthattuk, hogy nem teljesen igazolódtak be azok a félelmek, melyek szerint az új eszközök, a reproduktív médiumok hatalmuk alá vonják a képeket, utóbbiak feloldódnak az előbbiekben. Előbbiek új keretfeltételeket teremtettek a képek számára, a fotózás nyilvánvalóan kihívást jelentett a képzőművészet számára, és bizonyos tekintetben ösztönzően hatott a hagyományos megjelenési formákra. A mediatizáció méginkább erősödött a digitális képek megjelenésével, és az 1993 óta képek továbbítására is alkalmas internettel - ám e folyamatok sem tudták annulálni a képek azon tulajdonságát, amit Horst Bredekamp nehézkedési erőnek nevez. A német művészettörténész úgy véli, a képeket

${ }^{235}$ V.ö.: Havasi János: Az egyszemélyes stáb - Bevezetés a videoújságírásba. Nordex, Dialog Campus, 2009.
${ }^{236}$ Barta Judit: „Ha nem megy ellenük, csináld velük!” Médiakutató, 2007/ősz 
nem tekinthetjük a mindenkori új médiumok alávetettjeinek. Az új képtechnikák talán elnyelik, megtörik, visszatükrözik vagy átengedik őket, mint a fénysugarakat, de azok ettől nem tünnek el, inkább „mindig új értelemnyalábokká alakulnak”. ${ }^{237}$ Ha nem vesszük észre a médiumokon túlmutató nehézkedési erőt, amellyel még a legillékonyabb képek is rendelkeznek, annak a veszélynek tesszük ki magunkat, hogy objektumai maradunk az általunk előállított vagy szemlélt képnek. „A képek történelmen átívelő érvényének és a történelmi pillanat kihívásainak kereszteződéséből származik a képek nehézkedési ereje, amely nélkül minden képtudomány nélkülözné az alapokat."238 Épp e nehézkedési erő miatt fontos, hogy az új platformokon megjelenő, új technikákkal készült, az újmédia felületein látható képeket is komolyan vegyük, megértsük jelentőségüket, ne elégedjünk meg a képek özönének kortünetként való regisztrálásával, hanem elemezzük őket a képi/ikonikus fordulat nyomán kirajzolódó, komplexitáson alapuló eszközök és módszerek segítségével, mint autonóm, önálló súllyal rendelkező instanciákat. ${ }^{239}$

\section{II.2. A képi meghatározottság mint tünethalmaz}

„Egy képi fordulat látomása, egy olyan kultúráé, melyet teljes mértékben uralnak a képek, mára globális méretü valóságos technikai lehetöséggé vált." 240

W.J.T. Mitchell

\section{II.2.1. Vizuális infláció}

A neveléssel foglalkozó szakemberek régóta vallják, hogy az ingerszegény környezet nem kedvez a személyiségfejlődésnek, a környezet ingergazdagabbá tétele azonban jelentősen javítja a későbbi társas és értelmi fejlődést. ${ }^{241}$ Aligha vonhatjuk kétségbe azon fejlődéslélektani irányultságú kutatások eredményeit, amelyek például az árvaházban élő, intellektuális ingerekben alig részesülő gyerekeket ért hátrányokról számolnak be, ${ }^{242}$ mégsem jelenthető ki

\footnotetext{
${ }^{237}$ Bredekamp, Horst: Fordulópontok. Az iconic turn ismertetőjegyei és igényei. In: Nagy Edina (szerk.): A kép a médiamüvészet korában. L’Harmattan, 2006. 21.

${ }^{238}$ U.o.

${ }^{239}$ V.ö.: Boehm, Gottfried: Die Wiederkehr der Bilder. In: Boehm, Gottfried: Was ist ein Bild? München, Wilhelm Fink Verlag, 1994.

${ }^{240}$ Mitchell, W.J.T.: A képi fordulat. In: Szőnyi György Endre, Szauter Dóra: A képek politikája. W.J.T. Mitchell válogatott írásai. Jate Press, Szeged, 2012. 135.

${ }^{241}$ Cole, Michael \& Cole, Sheila R.: Fejlödéslélektan. Osiris Kiadó, Budapest, 1998., 37.

${ }^{242}$ Clarke, A.M. \& Clarke A.D.B.: Thirty years od child psychology: A selective review. Journal of Child Psychology and Psychiatry. 1986/27., 719-759.
} 
egyértelmüen, hogy minél több a környezeti inger, annál eredményesebb a fejlödés - különösen a vizuális ingerek tekintetében kell óvatosnak lennünk.

Felmerül a kérdés, hogy vizuális értelemben egyáltalán beszélhetünk-e ingerszegény környezetről? Létezik-e ilyen? Hiszen, ha kevés mesterséges, emberalkotta tárgy, épület van a környezetünkben, a természet akkor is sokféle látvánnyal, számtalan vizuális úton (is) felfedezésre váró elemmel szolgál. Kivétel ez alól talán a nyílt tenger felszíne, vagy a homoksivatagok oázisoktól távol eső részei, netán a végtelen hómezők, ahol a látvány valóban alig szolgál változatossággal. Ezeken a helyeken azonban csak elvétve élnek és szocializálódnak emberek.

Az „ingergazdag” jelzőt általában pozitív értelemben használjuk. Olyan környezetre mondjuk ezt, ahol kellő mennyiségü impulzus ér bennünket, melyek segítik érzékszerveink finomodását, gondolkodási folyamataink beindulását, frissen tartják szellemünket. De vajon lehet-e egy környezet túlontúl ingergazdag? Egyre több pszichológus hívja fel a figyelmet arra, hogy ebben is van veszély. Vekerdy Tamás például többször emelt szót a túl sok játék, illetve az ún. fejlesztö játékok ellen, mondván, hogy csak a fantáziának is kellő teret hagyó, a belső képkészitést támogató szabad játéktevékenység az, ami valóban fejleszt. A túl sok játék között a gyermek tanácstalanul ül, és egyik sem köti le hosszútávon. A külső, vagyis a médiából, televízióból származó képek feldolgozhatatlan információkkal árasztják el, blokkolva a belső képkészítést, ezáltal a feszültségek, indulatok, szorongások feldolgozását, feloldhatóságát is. ${ }^{243}$

A nyugati civilizáció embere vizuális szempontból vitathatatlanul ingergazdag környezetben él, képek tömkelege vetélkedik a figyelméért. Hogy ez a tény milyen hatással van a pszichés egészségre, a fantáziára, a koncentrációs képességekre, az a médiapszichológia egy fontos kutatási területe. Jelen esetben csak regisztráljuk ezt a tényt, mint a képek által meghatározott létállapot egy tünetét. A környezet vizuális ingergazdagságának egy bizonyos határon túli felfokozottsága azonban egy újabb tünethez vezet: a vizuális inflációhoz.

A vizuális impulzusok mérésével a szociológusok is foglalkoznak: azt a mérőszámot, amely egy adott időpontban egy adott területen jelzi a képek számát, képsürüségnek nevezik. Magától értetődően az emberi civilizációtól távol eső természeti tájakon, például egy sivatagban, amelyen átutazva órákon át gyakorlatilag ugyanazt látjuk, ez az érték $1 / \mathrm{km}^{2}$ is lehet. A legnagyobb városok bevásárlóközpontjaiban viszont több tízezer kép is jut egy négyzetkilométerre. A látványképek különböző időtartamokig tárulnak a szemünk elé. Ha túl gyorsan váltakoznak, akkor nem tudjuk érzékelni, így fixálni sem őket. Helmut Langer a

\footnotetext{
${ }^{243}$ Vekerdy Tamás: A képernyők varázsa. In: Szávai Ilona (szerk.): Tévé előtt-védtelenül? Tanulmányok a média hatásáról. Pont Kiadó, Budapest, 2010. 14-20.
} 
nagyvárosi utcaképet vizsgálva 1985-ben megállapította, hogy van egy bizonyos határ, amelyen felül hiába éri az embert számtalan vizuális inger, nem tudja őket felfogni. A tudatos szint feletti vizuális ingerek szinte kioltják egymás hatását, és mintegy az érzékelés peremére kerülnek. Ezt a jelenséget nevezi Langer vizuális inflációnak. ${ }^{244}$

A vizuális inflációhoz vezető folyamatban a változás és változatlanság kettősének is szerepe van. Vizuális környezetünk látszólag változatos, valójában azonban hozzászoktunk ehhez a színességhez, képgazdagsághoz. A képeket nem csak a mennyiségük miatt nem vesszük észre, hanem azért is, mert elfedi őket a megszokás. Ahogy Flusser is rámutat: a változás informatív, a megszokott redundáns. Minket elsősorban redundáns fotók vesznek körül, annak ellenére, hogy folyamatosan cserélődnek körülöttünk: egyik redundáns fotó helyére egy másik redundáns fotó kerül. „Számunkra a változatlanság lenne informatív, rendkívüli, kalandos”245 - írja Flusser. Hogy igaza van-e azt csak akkor tudnánk megmondani, ha egyszer valóban bekövetkezne, hogy hosszú időn át ugyanazokat a képeket látnánk a képernyőkön; hiába görgetnénk lejjebb és lejjebb a közösségi oldalon, minden nap ugyanazt kapnánk, a tévécsatornák programja nem frissülne, és a napilapok címlapján is mindig ugyanaz a látvány tárulna elénk... Ez az opció azonban annyira bizarr a ma emberének, hogy elképzelni is nehezen tudjuk. Nem csupán a képektől függünk, hanem a mindig megújuló képektől! A képek állandó cserélődéséhez vagyunk hozzászokva. Jól alátámasztja ezt az a tény, hogy ma már olyan digitális képkereteket is lehet vásárolni, amelyekben állandóan változik a tartalom. Így már a hagyományosan falra függesztett családi képeinkben sincs semmi állandó, a keretből mindig más arc néz le ránk.

Az arcokhoz kapcsolódva most tegyünk egy kitérőt, hiszen az emberi arcról készült képekhez való hozzáállás változása jól szemlélteti mind a vizuális inflációt mint tünetet, mind pedig a vizuális dokumentációképzés mögött felfejthető szellemi-kulturális folyamatokat.

\footnotetext{
${ }^{244}$ Langer, Helmut: Visuelle Gestaltung - visuelle Inflation. In: Format, 17/2., 1985. 17-24.

${ }^{245}$ Flusser, Vilém: A fotográfia filozófiája. Tartóshullám - Belvedere - ELTE BTK, Budapest, 1990. 53.
} 


\section{II.2.2. Egy példa: Az emberi arckép devalválódása}

„Isten újra szólt: Teremtsünk embert képmásunkra, magunkhoz hasonlóvá. Ök uralkodjanak a tenger halai, az ég madarai, a háziállatok, a mezei vadak és az összes csúszómászó fölött, amely a földön mozog. " 246

Teremtés könyve, 1.26 .

$\mathrm{Az}$ arcok speciális ingereket jelentenek a látó ember számára: észlelésükre rendkívül fogékonyak vagyunk, érdekesebbnek tartjuk, könnyebben ismerjük fel öket, mint bármilyen más, látott dolgot. ${ }^{247} \mathrm{Az}$ emberi arc képe évezredeken át kitüntetett szerepet kapott a mindennapokban, felfokozott figyelemre és tiszteletre tartott számot. A leképezett, tehát megörökített arcnak olykor nagyobb tisztelet járt ki, mint az enyészetre ítélt emberi testhez tartozó változatának. Az ősök képmása számos kultúrában féltve őrzött tárgy volt, amely nem ritkán szakrális cselekmények középpontjában állt. Napjainkra azonban eltünt az arcképeket övező áhítat, azokkal a legprofánabb körülmények között találkozunk. Az arcképek inflációjának lehetünk tanúi, képmásunk mindennapos, eldobható használati tárggyá vált, és önmagunk képi reprodukciójával szemben már alig támasztunk igényeket.

Gyenge Zoltán felhívja a figyelmet a magyar képmás szó nagyszerüségére, hiszen ilyet sem az angolban sem a franciában (lásd a latin kiindulópontokat: „,imago” és ,, alter ego”) nem találunk, és a német „Abbild” kifejezés sem adja vissza annyira pontosan a mélyebb jelentést, mint a magyar. Hegel gondolataira utalva rámutat, hogy a „kép”-nek a „más”-a annak kifejeződése, hogy a személy csak formájában van jelen: azaz a kép a magánvalósága, míg annak „imágóként” megjelenése az önnön más-léte. „Más mint a kép. A kép nem az élő személy, hanem annak nem élőként kifejeződése, azaz egy olyan kvintesszencia, amelynek nincs köze a tér és az idő koordinátáihoz.” Gyenge Zoltán szerint a „kép”, mivel „más” mint az élő, nem öregszik, mellőzi az időt. ${ }^{248} \mathrm{Ha}$ visszaemlékszünk Roland Barthes már idézett gondolatára, mely szerint a fotó - minden más fizikai képpel ellentétben - nem különbözik attól, amit ábrázol, hanem tautologikus, és összenő az ábrázolttal ${ }^{249}$, akkor adódik a kérdés: az arcról készült fotó talán már nem tekinthető képmásnak abban az értelemben, ahogyan Gyenge Zoltán - elsősorban képzőmüvészeti alkotások kapcsán - megfogalmazta? Csökkent volna a

\footnotetext{
${ }^{246}$ Biblia - Ószövetségi és Újszövetségi szentírás. Szent István Társulat, Az Apostoli Szentszék Könyvkiadója, Budapest, 2011., 22.

${ }^{247}$ Séra László: Müvészet és arcészlelés - az arckép. In: Révész György (szerk.): Az emberi arc. Pro Pannónia Kiadói Alapítvány, Pécs, 2010. 164.

${ }^{248}$ Gyenge Zoltán: Kép és mitosz II. A mitológia esztétikája. Typotex, Budapest, 2016. 152.

249 Barthes, Roland: Világoskamra. Európa Könyvkiadó, Budapest, 1985., 11.
} 
képmás ábrázolthoz képesti mássága? Mennyiben tölt be más szerepet a fotó-képmás, mint a nem-technikai képmások, és miben ragadható meg a különbség?

\section{Az arckép státuszának megváltozása}

Nem csak a keresztény vallásban találkozhatunk azzal a hittel, miszerint Isten a saját képére teremtette az embert. A képmásnak szinte valamennyi hitben kitüntetett szerepe van, az istenség és az ősök másának létrehozása nagy körültekintést, az elkészült képmás pedig különleges védelmet, örizetet igényel - hiszen, ha az ellenség hozzá férkőzik, az a közösség pusztulását, romlását okozhatja. A rontó mágia és a vadászmágia is azon alapul, hogy a képmáson elkövetett sérelem az ábrázoltra is kihat. Tudjuk, hogy a természeti népek tartottak a fényképezőgéptől, hiszen úgy hitték, képmásukkal a fotós a lelküknek, vagy a lelkük egy részének is birtokába jut. A zsidó vallás és az iszlám pedig tiltja az emberábrázolást, s e tilalom szintén a képmás különleges mivoltára, értékére utal. ${ }^{250}$

Az arckép a legszorosabb értelemben vett képmás, amely az egész embert jelképezi, és mint ilyen, minden korban kiemelt jelentőséggel bírt, felfokozott figyelemre és tiszteletre tartott számot, megvolt a maga kitüntetett helye. E kitüntetett pozíció hanyatlását már Walter Benjamin is regisztrálja 1936-ban, amikor arról ír, hogy a kiállítási érték kezdi kiszorítani a kultikus értéket. „Ez utóbbi azonban nem hátrál ellenállás nélkül. Az utolsó sánc mögé húzódik, s ez az emberi arc." ${ }^{251}$ Úgy véli, nem véletlen, hogy a korai fotográfia középpontjában a portré áll, ugyanis a kép kultikus értéke elhunyt szeretteink emlékezetének kultuszában lel végső menedékre. „A régi fényképekröl az emberi arcok tünékeny kifejezésében int felénk utoljára az aura. Innen fakad ezeknek a régi képeknek a mélabús és semmi máshoz nem hasonlítható szépsége.” ${ }^{252}$ Ekkor tehát még tetten érhető a képek időn kívülisége, kvintesszencia-jellege.

Az elhunyt hozzátartozók, ősök képe körül gyakran házioltárt rendeztek be, amely a vallásgyakorlás, az ima, az emlékezés, a közbenjárás kérésének helye is volt - hiszen a képmás révén velünk marad, aki már elhunyt, továbbra is tartható vele valamiféle kapcsolat. Erre utaló jelek még a XIX.-XX. századi paraszti portákon és polgári lakásokban is megfigyelhetők voltak, és napjainkban sem ritka, hogy egy-egy sarokba, falfelületre, komódra gyüjtik az emberek a családi fotográfiákat, emléktárgyakat, hogy olykor-olykor megálljanak előttük egy percnyi emlékezésre, számvetésre. Emögött már nem az a hit munkál, hogy így az ősök lelkének

\footnotetext{
${ }^{250}$ Hoppál - Jankovics - Nagy - Szemadám: Jelképtár. Helikon kiadó, 2010. 30.

${ }^{251}$ Benjamin, Walter: A müalkotás a technikai reprodukálhatóság korában. (ford.: Kurucz Andrea, Mélyi József) VI. rész http://aura.c3.hu/walter_benjamin.html (letöltés: 2018.02.02.)

252 U.o.
} 
egy darabja velünk marad, de az elhunytak, illetve a távol levők emlékének örzése ma is része az egyén identitásképzésének, segít megtalálni helyünket a világban.

Ma azonban már nem csak kiemelt, szakrális helyeken találkozhatunk emberi arcképekkel, hanem sokkal profánabb körülmények között is. Azt már régen megszoktuk, hogy óriásplakátokról néznek vissza ránk hatalmasra nagyított emberarcok. Az sem kelt bennünk megütközést, ha félig letépett, vagy épp eső áztatta, gyürött, felhólyagosodott arcokkal találkozunk. Már azon sem lepődünk meg, ha termékcsomagolásokon, ruhadarabokon, különböző használati tárgyakon látjuk őket. Vegyünk néhány groteszk példát, melyek felett a mindennapokban elsiklunk, és csak akkor tünnek bizarrnak, ha mélyen belegondolunk abba, mivel állunk szemben, és milyen messzire jutottunk a szakrális tartalommal felruházott arcképektől. Ha elindulunk egy városi körútra, és felszállunk egy villamosra, könnyen lehet, hogy az előttünk szétnyíló ajtó egy arcot szel ketté: a marketingesek nem feltétlenül gondolnak bele, hogy a kocsira és annak ajtajára felfestett reklám hogyan torzul, ha lehúznak egy ablakot vagy kinyitják az ajtót. Számukra semmi jelentősége nincs, hogy a reklámfotón egy tárgy vagy épp egy emberi arc szerepel. A jármüre felszállva bizonyára találkozunk bevásárlótáskákat hordozó emberekkel - a bevásárlótáska szintén megszokott reklámfelület, amelyről gyakran néznek vissza ránk tökéletesre sminkelt, retusált arcú fotómodellek. Ám hiába a grafikus abbéli igyekezete, hogy a valóságosnál szebbé változtassa a modellt, ha a szatyorba tömött tárgyakon megfeszül a kétdimenziós kép, eltorzul az arc.

A mai ember identitászavarát jól mutatja, hogy az sem ritka, ha más, számára idegen ember arcával a mellén rója napi útjait. Nem csak sztárokéval vagy politikusokéval, hiszen a divatcégek olykor teljesen ismeretlen modellek arcát nyomtatják - díszítő motívumként például női pólókra. Mindez különösen bizarr, amennyiben a modellénél kevésbé szerencsés testalkatokra feszülve látjuk az eltorzult emberarc-motívumot. De láttunk már arcot tejfölöspoháron, zoknicímkén, vagy éppen hashajtóreklám plakátján, hiszen egy megfelelő arccal bármi eladható, és egy-egy arc minden termék eladásához fellelhető. A hosszan sorolható példák azonban egyöntetüen mutatják, mennyire megváltozott az arckép státusza és funkciója. Egyéni képmásunk értéke pénzre váltható lett, de sokan ingyen is mások rendelkezésére bocsátják, vagy épp fizetnek azért, hogy közszemlére kerüljön.

Hogyan jutottunk el a tisztelettel és áhítattal körülvett arcképektől a csak pillanatokig funkcionáló, majd hulladékként kezelt arcképekig? Milyen katalizátorai voltak ennek a folyamatnak? Mielőtt ezt megvizsgálnánk, érdemes figyelembe venni azt a tényt is, hogy nem csak a képmáshoz, de annak „eredetijéhez” való viszony is megváltozott. Sosem tett az ember ilyen sokat azért, hogy - egyfelől - változatlanul, vagyis fiatal formájában konzerválja az arcát, 
másfelől pedig azért, hogy különféle beavatkozások révén (a sminktől a plasztikai sebészetig terjedő skálán) megváltoztassa azt, ha valamit nem érez rajta megfelelőnek. Az egyediséget szívesen cseréli általánosra, a közízlésnek megfelelő sablonra. De míg arcával gondosan bánik, kozmetikumokkal kényezteti, addig az arról készült képek sorsa iránt gyorsan közömbössé válik. Egy rövid ideig nagyon is fontos, hogy minél többen lássák és méltassák azokat legalább a közösségi oldalakon reakciót váltson ki másokból - de pár nappal később a feledés homályába vesznek. Mindeközben fel sem merül az aggodalom, hogy milyen folyamatoknak szolgáltatja ki képmását. (Pedig a példák azt mutatják, bármely képpel bármi megtörténhet: az újmédia jelenségeinek kiszámíthatatlanságát, a folyamatok megjósolhatatlanságát jól illusztrálja annak a budapesti nyugdíjasnak az esete, akiből az orosz internet mémet gyártott, $\mathrm{s}$ arcképe „Hide The Pain Harold” néven megkerülte a világot, számos szituációba ágyazva. ${ }^{253}$ )

Nem csak a ma emberének arca van kiszolgáltatva a tömegek számára, de visszamenőleg is elinfláljuk a letűnt korok képviselőinek képmását. Például II. Ramszesz lelke - az ő hite szerint - nem lelhetett békét, hiszen testét nem csupán megbolygatta a modern ember, de mumifikált, összeaszott arcának fotója számos szögből lefényképezve megtekinthető az interneten. És azok sem járnak sokkal jobban, akiknek a teste már elporladt. Mindazok a történelmi személyiségek ki vannak téve hasonló folyamatoknak, akikről valaha portréfestmény vagy más ábrázolás készült: ha ezek bekerülnek a tankönyvekbe, a diákok bajuszt rajzolnak nekik. Bizonyára nem is várható el, hogy tisztelettel viszonyuljanak egy arcképhez, amikor mindenütt azt látják maguk körül, hogy az arc vagy éppen a test képe árucikk, mindennapos használati tárgy.

\section{A portréval szemben támasztott igényekben bekövetkező változások}

Az ősművészetben, a természeti népek művészetében, a népmüvészetben nincs különösebb jelentősége a hasonlatosságnak, a vonások hű megragadása nem cél, a beazonosítás inkább szimbólumok és attribútumok révén történik. Nem az a fontos, pontosan hogy nézett ki az ábrázolt személy, sokkal inkább az, hogy milyen hatást gyakorolt a közösségre, miért, miként emlékezünk rá, milyen ideák kapcsolódnak hozzá. Az egyéniség, az egyedi vonások ábrázolásának szerepe, a modellhez való hasonlóság a történelem folyamán hol nagy jelentőséggel tör elöre, hol háttérbe húzódik.

253 Szily László: Hogyan lett egy budapesti nyugdijasból Hide The Pain Harold, a netes világsztár. https://444.hu/2016/03/10/hogyan-lett-egy-budapesti-nyugdijasbol-hide-the-pain-harold-a-netes-vilagsztar (letöltés: 2018.02.07.) 
Az arckép egyik megjelenési formája a portré ${ }^{254}$, amely Séra László definíciója szerint egy meghatározott személy individuális ismertetőjegyeivel ellátott képmás, amely az emlékezés és az emlékeztetés ösztönzéséből fakadó, kultúráról-kultúrára és történeti stílustól függően változó, központi kifejezési forma. ${ }^{255}$ Gadamer a portréról mint a kép egyik általános lényegi vonásának kiemeléséről ír: „Minden kép a lét gyarapodása, s lényegéhez tartozik, hogy reprezentáció, megmutatkozás." A német filozófus szerint a portré sajátos esetében a reprezentáció személyre vonatkoztatott értelmet kap, hiszen esetében az individualitás az, amit reprezentatív módon bemutatnak. „Mert ez azt jelenti, hogy a bemutatott saját maga mutatja meg a portréban és saját magát reprezentálja vele. A kép nem csupán kép, s főleg nem csupán képmás, hanem hozzátartozik a bemutatott jelenéhez vagy jelenlegi emlékéhez. Ebben áll sajátos lényege."256

Az önálló portrét mint az egyes emberalak természethü és világi rendeltetésü megörökítését többnyire a reneszánsz vívmányának tulajdonítják, ${ }^{257}$ ám történetének gyökereit az ókorban találjuk: az emberiség legkorábbi ismert, individuumot is megragadó ábrázolásai az ókori Egyiptomból származó fáraó-portrék. A hellenizmus művészetében elsősorban a portrészobrok tanúskodnak az arcvonások hü ábrázolása iránti fogékonyságról. E törekvés a Nyugatrómai Birodalom bukása után háttérbe szorul, és majd a donátorok által festetett vallásos képeken köszön vissza ismét, amelyekre a festő magát az adományozót is odafesti, először apró méretben, majd a donátorok lassan egyenértéküvé válnak az ábrázolt szentekkel, „,csupán annyi a különbség, hogy míg ők térdelnek, a szent vagy a Madonna kegyesen lemosolyog rájuk"258 (lásd pl. Hans Holbein: Meyer polgármester Madonnája). A reneszánsztól pedig már nem kell ürügy az egyéniség minél árnyaltabb, sokrétübb bemutatására, amelynek szolgálatába állítják a testtartást, a fejtartást, a kéztartást, a hátteret. Ezek mind mesélnek nekünk valamit az ábrázolt jelleméről, habitusáról - és természetesen társadalmi státuszáról is. A portréfestés müfajának diadala ezután végigível a következő századokon, kialakul egy hagyományrendszere, esztétikai szabályrendszere, és csak a fotográfia megjelenése változtat radikálisan a célkitűzésein.

Az emberi arcképek történetében kétség kívül a fényképezés felfedezése jelentette a legfontosabb fordulópontot, a profanizálódási folyamat, az auravesztés kezdetét nagyjából ekkorra kell tennünk. Katalizátora a feltörekvő középosztály volt, mely az arisztokráciát

\footnotetext{
${ }^{254}$ Ugyanakkor a portré nem mindig arckép, hiszen létezik félalakos, egészalakos portré is. Az arc azonban ez utóbbiaknak is hangsúlyos, meghatározó része.

${ }^{255}$ Séra László: Müvészet és arcészlelés - az arckép. In: Révész György (szerk.): Az emberi arc. Pro Pannónia Kiadói Alapítvány, Pécs, 2010. 164.

${ }^{256}$ Gadamer, Hans-Georg: Igazság és módszer. Osiris Kiadó, Budapest, 2003. 174.

${ }^{257}$ Garas Klára: Olasz reneszánsz portrék. Corvina, Budapest, 1965.5.

${ }^{258}$ Passuth Krisztina: A festészet mühelyében. Móra Kiadó, Budapest, 1964. 57.
} 
utánozva tömegesen rendeli a portrékat. A képmások elgépiesedése már a festők mühelyeiben megindul, akik árnyképekkel, sziluettrajzokkal és fizionotrászokkal ${ }^{259}$ igyekeznek kielégíteni az igényeket, mialatt sorra születnek meg a fotózás eljárásának elterjedését szolgáló találmányok. Szinte már az első maradandó fényképek elkészülésének idején ${ }^{260}$ nyilvánvalóvá vált, hogy az új eljárás kiválóan alkalmas az élethü portrék megalkotására, melyek már az új igények, a realista dokumentáció mindenekfelettisége felé mutattak.

A fényképezett portré műfaját leginkább a földön két lábbal álló polgárság realitásvágya hívta életre, akik már nem feltétlenül tartottak igényt azokra a többletekre, amelyek a képzőművészek egyedi látásmódja révén kerültek a képre. (Jan van Eyck, Tiziano, Velazquez, Rembrand, Frans Hals és a többi legendás portréfestő öröksége azonban folytatódott azon fotóművészek képein, akik a portréfotózást nem csupán reprodukciós-reprezentációs eljárásként értelmezték.)

Az első fotó-portrék megszületésének idején az arisztokrácia még utánzásra késztet, ám a tényleges hatalom már a nagypolgárságé. Míg az arisztokrácia saját felmenőinek képmásait őrizte az ősgalériákban ${ }^{261}$, addig a polgárok attól sem idegenkedtek, hogy számukra ismeretlen személyek arcképeit megvásárolják és hazavigyék - amikor a fényképezés eljárása még újdonságnak számított. ${ }^{262}$ (Itt tehát megtaláljuk annak az attitüdnek az előképét, amely a mai embert arra készteti, hogy idegenek arcmását hordja a ruházatán vagy teret adjon nekik használati tárgyain.) Erre azonban akkor nem sokáig volt szükség, hiszen az eljárás tökéletesedésével kiderült: a fotó révén soha nem tapasztalt könnyedséggel lehet levetetni ${ }^{263}$ az emberi arcot.

Az első portréfotó-stúdiót Alexander Wolcott nyitotta meg 1840-ben New Yorkban, de a következő évben már Európában is sorra nyíltak a mütermek. Az arckép hétköznapivá válásának fontos lépcsőfoka volt az ún. vizitportrék megjelenése. André-Adolphe-Eugene

\footnotetext{
${ }^{259}$ Egy ládában elhelyezett, pantográfból és egy célkereszttel ellátott csőből álló szerkezet segítségével a láda belsejébe szögelt papírlapra kirajzolhatóvá váltak a pontos arckontúrok. Lásd: Kolta Magdolna - Töry Klára: $A$ fotográfia története. DFM, Budapest, 2007. 15.

${ }^{260}$ Az egyik első sikeres, maradandó fényképet, a Kilátás a dolgozószobából címüt 1827-ben készítette Nicéphore Niépce, több mint 8 órás expozícióval. Ahhoz, hogy az eljárás emberek megörökítésére is alkalmassá váljon, le kellett rövidíteni az expozíciós időt, de ennek folyamata már a következő években elindult.

${ }^{261}$ Igaz, az ösgalériákba olykor más családból származó jelentős személyek, fontos történelmi személyiségek és fiktív ősök portréit is beiktatták, ám ezt mindig tudatosan, jól meghatározható céllal, az eszmei rokonságot erösítve tették. V.ö.: Buzási Enikő (szerk.): Föúri ösgalériák, családi arcképek. Magyar Nemzeti Galéria, Budapest, 1988. ${ }^{262}$ Szilágyi Gábor: A fotómüvészet története. A fényrajztól a holográfiáig. Képzőmüvészeti Alap Kiadóvállalata, Budapest, 1982. 74.

${ }^{263}$ A fényképezkedés régies szóval: vetetkezés. A megrendelő levetette magát a fényképész vetetőgépével. Lásd: 'Levetet' szócikk A magyar nyelv értelmezö szótárában. Bárczi Géza - Országh László(szerk.) Akadémiai kiadó, 1962. http://mek.oszk.hu/adatbazis/magyar-nyelv-ertelmezo-szotara/kereses.php?kereses=levetet (letöltés: 2018.02.06.)
} 
Disdéri üzletember a kép méretét 6,3 x 10,5 cm-esre csökkentette, és ezzel új divatot teremtett. 1854-ben szabadalmaztatta a vizitportrét, a névjegykártyához hasonlóan osztogatható, sokszorosított képecskét. ${ }^{264}$ Itt már egyértelmüen tetten érhető a devalválódás, az arckép hétköznapivá válása, melynek alapvető feltétele a mennyiség növekedése, a sokszorosíthatóság.

\section{Az arckép útja az áhítattól a közönyig}

Kép és szemlélő viszonya alapjaiban változik meg a fénykép megszületésétől, hiszen hogyan is keltene áhítatot a kép, ha az a barthes-i gondolat értelmében összenő az ábrázolttal, és észre sem vesszük. Maga a tény, hogy képet látunk, nem tudatosul, figyelmünket csupán a rajta látott személy köti le, így az arc-fotó pontosan annyi tiszteletet vált ki, amennyit a fotón lévő személy. Sőt, talán még annál is kevesebbet, hiszen a találkozás aktusa részben virtuális síkon megy végbe, a viszony nem kölcsönös, az adott személy nem lát bennünket, nem kell megszólítanunk, passzívak maradhatunk vele szemben.

Emellett az arc inflációjához hozzájárultak azok a technikai találmányok, amelyek a fotózást a realista dokumentációtól - amely kezdetben olyannyira lelkesítette a fotózás híveit az olcsó illúziókeltés felé mozdították el. Ilyen volt például a retusálás ${ }^{265}$ eljárásának tökéletesítése: „Bármennyire is igényelte a polgár a természet valósághű, minél élesebb képét a fotográfiákon, már nem volt ilyen igénye, ha önmagát látta viszont azokon" - írja Rónay Gabriella. ${ }^{266}$ Megkezdődött a kép rajzába való manuális beavatkozás, amelynek mértéke az 1860-as években már a fotóművészet létjogosultságát is aláásni látszott: „,megfosztotta azt attól - a valóság hű, objektív tükrözésének képességétől - amire mind ez ideig, mint sajátosságra hivatkozhatott és amelyre legitimitását - illetve legitimitásra vonatkozó igényét - alapozta."267 Megjelent az utószínezett fotó, a mütermekben pedig az előkelő környezetet imitáló festett hátterek, papírmasé oszlopok, melyek mind a megrendelő hiúságának hízelegtek. (Ha innen ugrunk egy bő évszázadot, akkor azt láthatjuk, hogy ezek az igények ma is munkálnak, csak már automata programok tüntetik el a bőr egyenetlenségeit, egyenlítik ki az arc aszimmetriáját.)

\footnotetext{
${ }^{264}$ Szilágyi Gábor: A fotómüvészet története. A fényrajztól a holográfiáig. Képzőművészeti Alap Kiadóvállalata, Budapest, 1982. 90.

${ }^{265}$ Nincs megegyezés azt illetően, hogy Henry Collen, Emil Rabending vagy Franz Hanfstängl tekinthetö-e a retusálás atyjának. Annyi bizonyos, hogy 1855-ben már a nyilvánosság előtt mutogatták a retusálás nélküli és a retusált képeket - a közönség nagy részének természetesen az utóbbi nyerte el a tetszését. (bővebben lásd: Szilágyi Gábor: A fotómüvészet története. A fényrajztól a holográfiáig. Képzőmüvészeti Alap Kiadóvállalata, Budapest, 1982. 116.)

${ }^{266}$ Rónay Gabriella: A portré- és zsánerfényképezés fotótörténeti áttekintése. GDF Oktatástechnológiai Tanszék, 2005. http://mek.oszk.hu/09600/09694/html/index.html (letöltés: 2018.01.28.)

${ }^{267}$ Szilágyi Gábor: A fotóművészet története. A fényrajztól a holográfiáig. Képzőmüvészeti Alap Kiadóvállalata, Budapest, 1982. 94.
} 
Megjelentek tehát az olyan fényképek, amelyeken festőecset igazítja ki azt, amivel a természet nem bánt kegyesen, noha épp a fotó büvöletében vetettük el mindazt, ami egy festett portrén eltér a pillanatnyi realitástól. A fotó hitelességének elillanása tovább csökkentette annak értékét. E tendencia egészen napjainkig ível: pontosan tudjuk, hogy a magazinok címlapjáról vagy a plakátokról ránk tekintő modellek arcvonásai a valóságban másmilyenek, így értékük a puszta dekoráció szintjére csökkent. Mint képmások, nem keltenek tiszteletet, de már figyelmet is alig $^{268}$. Mielőtt azonban visszatérnénk a jelenbe, vizsgáljuk meg, hogy a retusált fotók megjelenésével párhuzamosan hogyan változott a portréfestészet.

Az emberi arckép státuszának elbizonytalanodása már az impresszionista festészet virágkorában érzékelhető volt. Legalábbis erre mutat rá Bárdos Artúr esztéta, aki 1914-ben úgy érezte, hogy a portré szerepe néhány évtized óta lassú csökkenést és visszafejlődést mutat, és „sosem volt még a portré a festészetnek annyira elhanyagolt mostohagyermeke, sosem esett még annyira távol a festészet aktuális izgalmainak minden fókuszától, mint manapság."269 Bárdos úgy vélte, a XX. század elején a portré nem tart lépést a festészet haladó irányaival, „melyek teljesen a portré szempontjainak mellőzésével, teljesen a portrén kívül vívják meg a maguk létének küzdelmét." ${ }^{270}$ Ennek egyik okát a fotográfia fellendülésében látta, amelynek eredményeképp a konstatáló portré helyébe az impresszionisztikus portré lépett, amely a portréülés minden intimitását el akarta mondani a vásznon, és ez az „,in-time” portré már irtózott minden reprezentatív szándéktól. Bárdos szerint az impresszionisták annyi új és értékes szemponttal gazdagították a portrét, hogy ezek kárpótolnak bennünket bizonyos hiányokért ám szerinte már az impresszionizmus mủvészi tendenciái sem találkoztak a portré leglényegesebb feltételeivel. Bárdos úgy véli, a festészet különböző irányai különbözőképpen foghatják föl a portrét, magának a müfajnak lényege azonban ez marad: az ember egyéniségének tükröződése a festő világszemléletében, másszóval: az emberábrázolás. Az impresszionizmus azonban az embert már csak egy természet-szelet gyanánt tudta szemügyre venni, és az azt követő irányzatok is távol maradnak a portréfestés lényegétől. „A festőknek, akik a maguk kifejeződésének új útjait keresik, nem mondhatjuk, és hiába is mondanók, hogy ha portréról van szó, másként fessenek és mondjanak le legaktuálisabb, legizgalmasabb

\footnotetext{
${ }^{268}$ E kijelentés látszólag ellentmondásban áll a tizenéves korosztály viselkedéskultúrájának jellemzőivel, melynek része például az előadóművészek iránti rajongás. E rajongásnak valóban a képek és mozgóképek jelentik az alapját, hiszen a valóságban ritkán találkozik a rajongó és a rajongás tárgya. Az utóbbi évtizedekben azonban egyrészt e viszony átalakult: a rajongás tárgya már nem feltétlenül a tisztelet tárgya. Másrészt az internetnek köszönhetően bármikor hozzáférhetők a róla készült, legújabb képek, így egy-egy posztert vagy újságkivágást már nem tartanak akkora becsben, mint a korábbi generációk. A bálványozott személy képe mint tárgy, már korántsem tölt be akkora jelentőséget a sztárkultuszban, mint korábban.

${ }^{269}$ Bárdos Artúr: A portré hanyatlása. In: Művészet (Szerk.: Lyka Károly) XIII. évfolyam, 3. szám, 1914., 153. ${ }^{270}$ U.o.
} 
vágyaikról."271 - írja Bárdos, és tanulmánya végén levonja a konklúziót, hogy a portrét e pillanatban (1914) a hanyatló müfajok közé kell sorolni.

Természetesen bőségesen találkozhatunk később kiváló, sőt, korszakalkotó portrékkal a modern müvészet különböző irányzatainak berkeiben (lásd pl. Van Gogh, Schiele, Picasso, Matisse, Modigliani, Schnabel, itthon Rippl-Rónai, Nemes Lampérth vagy Tihanyi Lajos portréit - hogy csak néhány kép megvillanjon bennünk a teljesség igénye nélkül). Bredekamp egyenesen úgy fogalmaz, hogy a XVI. század után a XX. ismét kedvező időszak volt a lehetőségeit végletekig tágító arcképfestészet számára, „amely Francis Bacon deformált portréiban éppúgy elszakadt az absztrakciótól, mint az ábrázolástól, Gerhard Richter arcképeiben pedig a fotográfiával szembeni kihívást magának a portréalanynak a részévé tette." 272 A célkitüzéseknek és megfogalmazásmódoknak azonban szükségszerüen változniuk kellett a portréfotó térhódításával. E változást a közönség nem feltétlenül tudta követni, és sokan ugyanolyan igényeket támasztottak a portréfestménnyel, mint a fényképezett arcképpel szemben. Ezt figurázza ki a lengyel festő-író-filozófus, Stanisław Ignacy Witkiewicz, alias Witkacy, aki 1928-ban, „portréfestő vállalatának” szabályzatában ilyeneket köt ki: „Az ügyfél részéről bármiféle kritika kizárt. A portré az ügyfélnek nem kell, hogy tetsszen, a Vállalat nem engedélyezi a legkisebb kifogást sem, hacsak arra külön engedélyt nem ad. Ha a Vállalat megengedné magának a luxust, hogy meghallgassa az ügyfelek véleményét, már réges-régen megörült volna..."273

A fenti, ironizáló idézet is jelzi, hogy a fényképezés nyomán az arcképkészíttetésre már mindenki jogot formál, és a készíttető nem a kifinomult látásmóddal rendelkező, müvészetpártoló, műalkotásra vágyó arisztokrácia, hanem a tömegember, aki önmagát szeretné viszont látni, méghozzá a hiúságának minél hízelgőbb módon, szépnek, erősnek, fiatalnak. E szempontokból nem enged, akár fényképről, akár festményről van szó - s e kettő ekkor már szinte egyre megy. Ezen összemosódásnak is óriás szerepe van az arckép inflálódásában! Hiszen a fotó és a képzőművészet úgy tudja megtalálni a helyét egymással szemben, ha nyilvánvalóvá válik a kettő közötti különbség mind a célok, mind az eszközök tekintetében. A manipulált fénykép azonban gúnyt üz abból, ami miatt a fotó fontossá vált: az objektív, realista tükrözésből. Ugyanakkor a festett, rajzolt portré lényegétől is messze marad. A kettő között lebegő, öncélú kép a készíttetőn (és annak szük környezetén) kívül senki más számára nem

\footnotetext{
${ }^{271}$ U.o. 163.

${ }^{272}$ Bredekamp, Horst: Fordulópontok. Az iconic turn ismertetőjegyei és igényei. (Ford.: Kékesi Zoltán) In: Nagy Edina (szerk.): A kép a médiamüvészet korában. L’Harmattan, 2006. 20.

${ }^{273}$ S.I. Witkiewicz vállalat szabályzata, §2., Varsó, 1928. Magyar fordítás:

http://lengyelvalosag.blogspot.hu/2009/01/si-witkiewicz-portrfest-vllalat.html (letöltés: 2018.01.31.)
} 
képvisel értéket. Ezzel kezdetét veszi az olyan képek korszaka, amelyek sorsa iránt tökéletes közömbösséggel viseltethetünk. Megszünik tehát a képeket övezö feltétlen áhítat, és helyére lép a közöny.

\section{Az arckép és az önismeret igénye}

A portré az 1920-as évekig a fotómüvészet legrangosabb müfaja volt, onnantól kezdve viszont a fotóművészet alakulásában betöltött, meghatározó szerepe, befolyása megszünik - állítja Szilágyi Gábor, aki úgy véli, a fotómüvészek a világháború kitöréséig a képzőművészet befolyása alatt álltak, annak vonzásában-taszításában éltek. ${ }^{274}$ Ezt követően azonban a szálak egyre lazultak, és a fotózás kifejezésmódja inkább a mozgókép, a film hatása alá került.

Ahogy haladunk az időben, elhagyhatjuk a mütermeket és a fotografáló szakembereket is, hiszen a lakossági fényképezőgépek, a polaroid, majd a digitális gépek elterjedésével bárhol, bárki alkothat (arc)képet - kezdetben csak másokról, de a szembefordítható kijelző, a telefonokba épített kamerák, és a selfie-botok segítségével ma már önmagáról is. Megtörténik tehát az alkotó mellőzése, pontosabban az alkotó és az alany eggyé válik, saját hiúsága felett már maga diszponál.

Ernst Gombrich szerint a pillanatfelvétel átformálta a portrét, ugyanakkor a hasonlóság problémáját is új megközelítésbe helyezte, hiszen mást jelent az élet csendéletként való megragadása, és mást a vonások kimerevítése egy olyan pillanatban, amely az események sodrában nem is tudatosul, és az előzmények nélkül nehezen értelmezhető: például nincs, ami magyarázná a fintort, amely a pislogás vagy tüsszentés egy fázisában örökítette meg az alanyt. $^{275}$ A pillanatfelvételen látható arc olykor tulajdonosára egyáltalán nem jellemző kifejezést mutat, így egészen más információkat hordoz, mint a festmény, vagy akár a hosszan exponált, beállított fotográfia.

Mikor portrét készít, a festőművész, a szobrászművész, de még a fotóművész is a legsajátosabb, legegyénibb vonásokat igyekszik megragadni modelljéből ${ }^{276}$ - és ezek általában nem a legesztétikusabb, legszabályosabb vonások. Dominique Ingres meghatározása szerint a jó portré mindig egy kicsit karikatúra. ${ }^{277}$ „Hogy ezt a fajta ábrázolást a megrendelő elviseli-e

\footnotetext{
${ }^{274}$ Szilágyi Gábor: A fotóművészet története. A fényrajztól a holográfiáig. Képzőművészeti Alap Kiadóvállalata, Budapest, 1982. 108.

${ }^{275}$ Gombrich, Ernst: The Mask and the Face: The Perception of Physiognomic Likeness in Life and Art. In: Art, Perception and Reality. The Johns Hopkins Univercity Press, Baltimore, 1972. 16-17.

${ }^{276}$ Bár meg kell jegyezni, hogy a portré szubjektumának mibenléte körül élénk diskurzus bontakozott ki Jean-Luc Nancy, Gottfied Boehm és mások gondolatai nyomán. Lásd: Nancy. J.L.: A portré tekintete. Mücsarnok, 2010. és Bacsó Béla: Ön-Arc-Kép. Szempontok a portréhoz. Kijárat, 2012.

${ }^{277}$ Idézi: Passuth Krisztina: A festészet mühelyében. Móra Kiadó, Budapest, 1964. 57.
} 
vagy sem, az már kulturáltságán és önismeretén múlik" - írja Passuth Krisztina. ${ }^{278}$ Ha ez valóban így van, napjaink fényképezkedő embere aligha tesz tanúbizonyságot mély önismeretről (a kulturáltságot most ne firtassuk) - és az önismeretre való igény eltünése a képekről egy újabb olyan tünet, amely a profanizálódás és a devalválódás felé mutat.

A XXI. század második évtizedében ${ }^{279}$ az ember valóságos önportré-készítési lázban ég, rendszeresen dokumentálja önnön (beépített retusprogramokkal kiigazított) vonásait különböző helyszíneken és szituációkban, hogy aztán elárassza a világhálót ezekkel a képekkel. Számos kutatás született a témában, melyekből leszürhető, hogy a magasabb önértékelés hajlamosít a gyakoribb selfie-posztolásra, ${ }^{280}$ illetve nagyobb eséllyel figyelhetők meg narcisztikus és pszichopata személyiségjegyek a gyakori posztolóknál. ${ }^{281}$ Mások azonban úgy vélik, nem szabad a selfie-t hiúságként értelmezni, ${ }^{282}$ és a vizuális kultúra egy újfajta kommunikációs eszközéről van szó, mely révén az ábrázolt üzeneteket kíván eljuttatni szűkebbtágabb ismeretségének. (Némelyik akár segélykiáltásként is értelmezhető, és egy éles szemü pszichológus leolvashatja róla a problémákat, melyekkel készítője küzd.) Annyi bizonyos, hogy a selfie ugyanúgy státuszt is szimbolizál, mint régen a portréfestmények, hiszen a háttér, a helyszín, a ruházat sokat elárul arról, hogy a szereplő hová jutott el, milyen körülmények között éli mindennapjait, hová kíván tartozni, milyen ízlésvilággal rendelkezik. Az arc, a haj állapota arról mesél, mennyi időt, energiát, pénzt képes áldozni az ábrázolt személy önmagára. A csoportos selfie-k pedig az ismeretségi kör kiterjedtségét és milyenségét mutatják meg. A művészi portréfestményhez (vagy müvészfotóhoz) képest többletet nehéz felfedezni bennük, annyival viszont kevesebbek, hogy annak jellemábrázoló törekvéseit nélkülözik, és a műfajra jellemző, megszokottá vált, erőteljes manipuláció miatt a szemlélő a hitelességüket is gyakran megkérdőjelezi. Ettől függetlenül, illetve éppen a manipulációval együtt, mégis egyre fontosabb részét képezik az egyéni identitásnak, amennyiben sokan e vitatott értékü müfaj révén fejezik ki önmagukat - vagy gondolják úgy, hogy kifejezhetik magukat vele.

Az egyik fontos motiváló tényező, amely minden bizonnyal valamennyi modellben ott bujkált, aki valaha festővászon, vagy egy fotóművész kamerája elé állt, az a kíváncsiság.

\footnotetext{
278 Passuth Krisztina: A festészet mühelyében. Móra Kiadó, Budapest, 1964. 57.

${ }^{279}$ A brit Oxford szótár szerkesztőbizottsága 2013-ban a selfie-t választotta az év szavának.

${ }^{280}$ Lásd pl. Agnieszka Sorokowska és társai 2015-ös kutatását: Selfies and personality: Who posts self-portrait photographs? https://www.researchgate.net/publication/283514572_Selfies_and_personality_Who_posts_selfportrait_photographs (letöltés: 2018.01.31.)

281 Seidman, Gwendolyn: Are Selfies a Sign of Narcissism and Psychopathy? Psychology Today, 2015. https://www.psychologytoday.com/blog/close-encounters/201501/are-selfies-sign-narcissism-and-psychopathy (letöltés: 2018.02.08.)

${ }^{282}$ Greenwood, Dara: Three Reasons Why We Shouldn't Confuse Selfies with Vanity. Psychology Today, 2014. https:/www.psychologytoday.com/blog/mirror-mirror/201409/three-reasons-why-we-shouldnt-confuse-selfiesvanity (letöltés: 2018.02.08.)
} 
Kíváncsiság az iránt, hogy a másik ember milyennek látja őt, mit vesz észre, mit emel ki tulajdonságaiból. Mindez jól szolgálhatta az önismeretet és az önelfogadást. A selfie ellenben sokszor már eleve hamis képet ad: a napjaink okostelefonjain futó programok megtaníthatók arra, hogyan fényképezzék szebbnek a tulajdonost: az egyedi arckaraktert figyelembe véve beállítható a bőrsimításnak, a vonások lágyításának, az árnyékok világosításának foka, sőt, keskenyebbé vagy teltebbé teszik az arcot - igény szerint. Tehát már utólagos retusálásra sincs szükség, az arckép rögtön az elkészítés után e manipulált formában néz vissza a modellre, aki szívesen hiszi el, hogy amit lát, az tényleg ő maga. Külső kontroll már nincs, hiszen sem művész, sem mester, de már egy laikus segítő sem kell az elkészítéséhez. Az eredeti, beavatkozás nélküli képet külső szemlélő nem láthatja, de már magának a modellnek sem kell szembenéznie vele. A megváltozott arcképkészítési szokások tehát az önismeret tekintetében jóval nagyobb felelősséget terhelnek az egyénre, magára hagyják abban a munkában, amely énképének és identitásának kialakítását segíthetné. Mindez becsatlakozik abba a problémakörbe, amit a virtualizálódás felvet: egyre több szálat szakít el, ami az egyént a természeti valósághoz kötné, és egy olyan világ felé löki, ahol egy elképzelt figura bőrébe bújva élheti életét.

\section{Arcképek áradata - mennyiségi növekedés}

A képmások mennyisége kétféle módon növekszik a világban: egyfelől a képkészítési aktusok száma ugrott meg elképesztő mértékben: egy-egy emberről magzati korától (lásd 3D ultrahangképek) haláláig több ezer kép készül. Ilyen sokrétü és alapos dokumentációs aktusokra korábban soha nem volt példa. Másfelől egy-egy kép megszámlálhatatlanul sokszor testesül meg - nem csak kinyomtatott formában, hanem a különféle eszközök képernyőin: egy-egy közösségi oldalra posztolt fotó valamennyi 'ismerős' státuszban lévő ember számítógépének monitorán, okostelefonjának kijelzőjén megjelenik.

A fotók posztolásában megnyilvánuló státuszjelzés leadására mind gyakrabban és gyakrabban támad inger, s e jelzések egyre inkább a pillanatnak szólnak, mintsem az örökkévalóságnak. Ha az arcképek célját és motivációit kutatjuk, megkerülhetetlen az idötényező. Régen a portré az örökkévalóságnak készült. A készíttető szeme előtt nem lebegett kisebb cél, mint az, hogy halála után a közvetlen leszármazottjai, valamint szükebb-tágabb közössége megtudhassa, milyen volt ő, emlékezhessen rá, megtudjon róla valamit. Napjaink szelfizőjének ilyesmi aligha fordul meg a fejében, ő csupán egy aktuális létállapotról kíván impressziót adni kortársainak, aktuális környezetének. Azonnali hatást szeretne kiváltani, az utókorral nem foglalkozik. 
De ha a szelfitől eltekintünk, és egy átlagos család fényképkészítési aktusainak motivációit vizsgáljuk, akkor még gyakran találkozunk azzal a hivatkozással, hogy „emlék” gyanánt fotóznak. Ám ezen „emlékek” kényszeres létrehozása akadályozhatja a természetes emlékezet szelektáló mechanizmusait, a lezáró és feldolgozó munkát, így ahelyett, hogy megkönnyítené, éppen hogy megnehezíti az identitás megszilárdulását.

Susan Sontag úgy véli, a múltjától megfosztott ember a legbuzgóbb fotós, hiszen jelene dokumentálásával kompenzálhat, új kapaszkodókat találhat. 1977-es könyvében rámutat arra is, hogy a fényképezés „éppen akkor válik a családi élet szertartásává, amikor Európa és Amerika iparosodó országaiban sebészkés alá kerül a család intézménye. Miközben a nagycsaládból kiválik a kiscsalád, ez a nyomasztóan zárt egység, megjelenik a fénykép, hogy megörökítse és jelképesen helyreállítsa a családi élet fenyegetett folytonosságát és már-már megsemmisülő kiterjedtségét." 283 A dokumentálásba menekülés, az emberi kapcsolatokban bekövetkező változások indukálta kényszeres leképezési vágy lehet az egyik magyarázata a rendkívül dinamikus mennyiségi növekedésnek.

A privát fotográfiák mellett emberi arcokkal találkozhatunk sajtófotókon, fotóillusztrációkon és PR-célú fotókon is. A számbeli gyarapodás valamennyi ágazatra jellemző, így a különböző, ismerős és idegen arcokat ábrázoló képek valósággal elborítanak bennünket. A mennyiségi viszonyok az ábrázolt és a kép között megfordultak: Régen a valóságos, hús-vér arcokhoz képest jóval kevesebb volt az arckép. Ma viszont arcképből van több, hiszen egy-egy élő ember arcáról akár napi rendszerességgel készülnek képek. Az értékvesztés tehát elkerülhetetlennek látszik.

Folyamatos a diskurzus annak kapcsán, hogy a képek mindennapi életben betöltött jelentőségének a fokozódása, az ezzel párhuzamosan végbemenő vizuális infláció, és a mindezeket kísérő virtualizálódás válságtünetekként foghatók-e fel, vagy csak változástényezőkként aposztrofálhatók. E dilemma az arcképek státuszának vizsgálatakor is felmerül, de az egyértelmü válaszra még várnunk kell.

Ha visszakanyarodunk a kiindulási ponthoz, és belehelyezkedünk az ősvallások, törzsi vallások azon felfogásába, mely szerint a képmás képviseli a modellt, és a képmással történtek rá is hatással vannak, akkor még további kérdések vetődnek fel: A képmáson keresztül inflálódik maga az ember is? Ha képmásunk mindennapos, eldobható használati tárgy lesz, mikor válunk mi magunk is azzá? Utódaink aligha kezelik majd fényképeinket azzal a tisztelettel, mint amivel még a XX. század embere is viseltetett nagyszülei, dédszülei

\footnotetext{
${ }^{283}$ Sontag, Susan: A fényképezésről. Európa Kiadó, 1981. 15.
} 
(korlátozott számú) fotográfiái iránt. Utánunk már olyan kezelhetetlen, és beláthatatlan mennyiségü, nagyrészt digitális jelként létező kép marad, amely nyilvánvalóan csekélyebb érdeklődést kelt majd, mint ha csak egy-egy arckép vonásait lehetne faggatni. Vonható-e párhuzam arcképeink sorsa és önnön sorsunk között? Mutathatja-e mindez az emberi méltóság mint érték erózióját?

Persze az sem kizárt, hogy teljes egészében el kell vetnünk mindazt, amit eddig az arcképkészítés céljairól és motivációiról gondoltunk, és más típusú kérdéseket kell felvetnünk: talán időközben elszakadtunk a képmásunktól? Az már nem képvisel, nem reprezentál bennünket, így felelősséggel sem tartozunk irányában? Nem zárható ki, hogy amit most inflációnak gondolunk, az valójában egy kommunikációs átalakulás része, és az arckép vizuális jellé, üzenethordozóvá, afféle kibővített emotikonná ${ }^{284}$ válik.

\section{II.3. A szükséges kép}

„A látványosság társadalmában az eröteljes képek ugyanazt a szerepet játsszák, mint a termőföld vagy az ingatlan vagyon: lelki szükségletet elégítenek ki. "285

Geoffrey Hartman

Láthatjuk tehát, hogy a képek már nem számítanak újdonságnak, nem feltétlenül figyelemreméltó és lebilincselő dolgok, mégis ragaszkodunk hozzájuk, kapaszkodunk beléjük, a létrehozás aktusa szinte kényszerként van jelen mind többek életében. A következő, megválaszolandó kérdés az, hogy miért ragaszkodunk redundáns képeinkhez? Milyen motivációk állnak a képi dokumentációképzés hátterében? Miért olyan lényeges, hogy az egyén vizuális portfóliója mind több és több elemből álljon?

Időzzünk el részletesebben azon állítás körül, mely szerint a képek egyre kevésbé az utókornak, a jövőnek, hanem egyre inkább a jelennek készülnek. Mindez ugyanis látszólag ellentmondásban áll azzal a jelenséggel, amelyre a pszichológusok is lépten-nyomon felhívják a figyelmet: az ember nehezen tudja megélni a pillanatot, a képek készítése gyakran elvonja a figyelmét mindazon élményektől, amelyekben része lehetne. Szánakozunk a nyaralókon, akik

\footnotetext{
${ }^{284}$ Az emotikonok (hangulatjelek, emoji-k, smiley-k) nyomtatott írásjelek olyan sorozatai, amelyek emberi arcot formálnak, és valamilyen érzelmet fejeznek ki. Például a mosolygó fej kettőspontból és zárójelből: :) Ezeket váltották fel a kis sárga kör alapú jelek, de a változatok skálája egyre szélesebb, egyre több féle képes emotikon szúrható be a beszélgetésekbe a különbözö eszközökön.

${ }^{285}$ Hartman, Geoffrey: The Cinema Animal. In: Loshitsky, Josefa: Spielberg's Holocaust. Critical Perspectives on Schindler's List. Bloomington, Indiana University Press. Idézi: Silverstone, Roger: Miért van szükség a média tanulmányozására? Akadémiai kiadó, Budapest, 2008. 148. Fordította: Károlyi Júlia
} 
a maguk elé tartott digitális kijelzőn keresztül csodálják a nevezetességeket. Megdöbbenünk a koncertek közönségén, amelynek tagjai telefonokat és táblagépeket tartanak a magasba, tekintetüket a színpad helyett arra szögezve. Pálcát törünk az édesanya felett, aki felteszi a közösségi oldalra a gyermekéről készült videót, amint épp anyák napja alkalmából verset mond neki - pontosabban az anyja arcát kitakaró telefon kamerájának. Egyelőre még az emberek nagy részében ellenérzés él ezekkel a jelenségekkel kapcsolatban, ám ez mind többször és többször törik meg, és egyre többen állnak be azoknak a sorába, akik szükségesnek érzik, hogy a nyaralásuk során bejárt tér minden fontosabb egységéröl, minden rendezvényröl, amelyen jártak, és minden élményről, amelyben részük volt, készüljön álló- vagy mozgóképfelvétel. Egyelöre még sokan vannak, akik megvetéssel tekintenek a szelfi-botokra vagy a kamerákba épített szépítő effektekre, ám úgy tünik, ezek gyorsak kerülnek a „ciki” kategóriából az elfogadottba, majd a preferáltba.

Ezek a képek olyannyira fontossá váltak, hogy mind többen hajlandók megfizetni $a z$ árukat, vagyis feláldozni a pillanat örömét annak öröméért, hogy látszólagosan örömteli pillanataikat - némi idő elteltével vagy épp azonnal - közzétehessék. Ily módon a létezés színtere nem a fizikai síkban van, hanem azon a virtuális platformon, ahol a kép publicitást nyer, ahol visszajelzésekre (lájkokra) tehet szert. Ám talán hiba lenne kizárni azt, hogy a másodlagosan, a világháló terében megélt pillanat nyújthat ugyanakkora örömöt, mint amit elsődleges formájában nyújthatott volna, amennyiben fel nem áldoztatik a képkészítés aktusának kedvéért. Ha nem nyújtana legalább akkora élvezetet, bizonyára nem cselekedne így senki. A kritikai attitüd fontos, de az arrogáns lesajnálás nem visz közelebb a megfejtéshez. E képek hazug, hamis voltát, az elkészülésükkor színlelt magatartásformákat persze lehet kárhoztatni, ám ezen magatartásformák sokszor a képkészítés aktusa nélkül is jellemeznék az egyén adott pillanatban tanúsított viselkedését. A jelenség kapcsán sokkal érdekesebb a csere oka. Miért cseréljük fel az átélt pillanat örömét a publikáláséra?

A lehetséges válaszok felvázolása előtt térjünk vissza a kiinduló problémához: ha fenntartjuk azt az állítást, hogy az így készülő képek nem a jövőnek, hanem a jelennek szólnak, akkor érdemes ezt pontosítani! Nem a pillanatnak, hanem egy kiterjesztett jelennek szólnak. Noha egyre rövidül a képkészítés és a képpublikálás aktusa között eltelő idő - hiszen ugyanannak a technikai eszköznek a segítségével elkattintás után rögtön meg is osztható a kép - a megosztott kép még egy bizonyos ideig, általában néhány napig kering a közösségi oldalon, reakciókat gyüjt be. Ezt követően is ott marad, ám ezután már egy jóval passzívabb létformában, és nagyrészt érdektelenné válik azok számára, akik számára egyébként elérhető. Azt nem tudjuk, hogy e képek több évtizedes távlatban maradandók lesznek-e, illetve az utókor 
hogyan fog viszonyulni hozzájuk. De éppen ez a tény, a jövőjük beláthatatlansága támasztja alá azt, hogy nem a jövőnek készülnek. Míg a papírképeket gondosan albumba gyüjtő emberben folyamatosan ott munkál a szándék, hogy megőrizzen valamit az utókornak, a szelfit megosztó ember szándéka inkább a pillanat láttatása egy kiterjesztett jelenben.

És most térjünk vissza arra a kérdésre, hogy miért cseréljük fel a látás nyújtotta gyönyört a láttatás nyújtotta gyönyörre? És egyáltalán: miért lett szükségletté a kép? A válaszokhoz két jelenség alaposabb elemzése vihet közelebb. Az egyik a szemlélés és szemléltetés nyújtotta élvezet, a másik pedig a kép tapasztalatforrásként való müködése.

\section{II.3.1. A kép mint élvezeti forrás}

Freud a szexualitást alkotó egyik ösztönként azonosította a szkopofiliát, a szemlélést mint gyönyörforrást, mely az erogén zónáktól teljesen független vágyként jelenik meg ${ }^{286}$. Ez egyike azoknak az alapvető késztetéseknek, drive-oknak, amelyek minden gyermekben megvannak születésétől kezdve. A látásban rejlő erotikus projekció gondolata már Szent Ágostonnál is felsejlik, aki szerint az okuláris vágy könnyen letéríthet bennünket utunkról. Augustinus szerint megkülönböztethető, mikor működnek érzékeink élvezet, s mikor kíváncsiság okából: „mert az élvezet egy nyomon jár azzal, ami szép, ami zengzetes, ami kellemes, ízes és gyöngéd; a kíváncsiság pedig ezek ellenkezője iránt is érdeklődik, nem azért, hogy kellemetlenségünket magára vegye, hanem azért, mert tapasztalni, ismerkedni akar." ${ }^{287}$ Ugyanakkor rámutat a borzadás iránti vágyunkra is, amely miatt egy szétroncsolt holttest vagy az akasztófa köré is odasereglenek az emberek. Ugyanez a vágy vagy kíváncsiság vezeti a televízió távkapcsolóját nyomkodó, vagy a neten szörföző embert is, amikor rátalál az olyan képi tartalmakra, melyek torzszülötteket, betegeket, nyomorultakat vagy más bizarr, kellemes látvánnyal bírónak semmi esetre sem nevezhető jelenségeket ábrázolnak. A szemlélés élvezete (illetve annak kíváncsisággal összefüggő komponense) tehát nem feltétlenül függ sem esztétikumtól, sem művészi értéktől, sem a látvány kellemességétől.

Ám nem csupán a szemlélés lehet élvezet forrása, hanem ennek az ellenkezője is lehetséges, vagyis gyönyörforrást jelenthet a szemlélés tárgyának lenni. ${ }^{288}$ Az önmagunkról készült fotók, beleértve a másokkal készíttetett képeket és az önportrékat egyaránt, kiválóan

\footnotetext{
${ }^{286}$ Lásd: Freud, Sigmund: Három értekezés a szexualitás elméletéröl. In: Freud, Sigmund: A szexuális élet pszichológiája. Budapest, Cserépfalvi, 1995., 31-131.old.

${ }^{287}$ Szent Ágoston vallomásai (ford.: Vass József). Budapest, Szent István Társulat, 1995., XXXV. fejezet: A kiváncsiság kísértései. 159.

${ }^{288}$ V.ö.: Mulvey, Laura: A vizuális élvezet és az elbeszélö film. Metropolis - Feminizmus és filmelmélet, 2006. http://metropolis.org.hu/?aid=118\&pid=16 (letöltés: 2018.03 .19 .)
} 
alkalmasak ennek átélésére. Vélhetően a szkopofília mögött lévő drive is felelős azért a belső kényszerért, amely a fényképezés lakossági elterjedése óta jellemzi az embert: rögzíteni a megélt látványt, azt, ami az adott pillanatban örömmel töltött el, ami valamilyen mértékü gyönyört, esetleg éppen borzadást okozott. Megragadni, konzerválni és közzétenni, másokkal is megosztani, szemlélni, szemléltetni és szemlélve lenni: mindez a digitális fotózás és az újmédia megjelenésével könnyebbé vált, mint valaha.

De miért fontosabb a láttatás, mint a biológiai-percepcionális képként elénk táruló látvány megélése? A kérdésre többféle lehetséges válasz is adható. Az egyik az, hogy valójában szó sincs tudatos választásról. A világhálón publikált digitális fotó egyszerre kecsegtet a látás és a látvány megosztásának, megmutatásának, a láttatásnak az élményével. Vagyis, a képkészítő nincs tudatában annak, hogy a pillanat kínálta élményt felcseréli a publikálás élményével, hanem úgy gondolja, mindkettőre igényt tarthat. Egy selfie esetében pedig akár mindháromra: a látás, a láttatás és a látva levés élvezetére. Nem számol azzal a ténnyel, hogy a fizikai/testi jelenlét egy bizonyos térben nem jelenti feltétlenül a psziché jelenlétét is, és sokszor utólag sem ismeri fel, hogy elszalasztott valamit. A másik magyarázat az, hogy tisztában van e ténnyel, de úgy gondolja, az élmény bepótolható a kép révén, az elkészült felvétel utólagos nézegetése által.

A harmadik lehetséges magyarázat valamivel összetettebb, és az önazonosság, az öntudat képlékenységében ragadható meg. Ehhez elő kell feltételeznünk egy történelem utáni embert - nevezhetjük talán posztmodern embernek is - aki elveszítette kapaszkodóit és hitrendszerét, világnézetének szilárdsága megrendült, valódi közösség nem veszi körül, nem találja önnön helyét a világban. Egy ilyen ember számára fontosabb az, hogy mások (a világháló nyilvánosságának tagjai) is lássák, amit ő, mások is érzékeljék, hogy ő az adott pillanatban érzékelt valamit, hiszen kétségbeesetten szomjazza a visszajelzéseket, a reakciókat, amelyek segítenek neki annak meghatározásában, hogy miként viszonyuljon az érzékelt, látott dologhoz. E külső segítség pedig nagyobb jelentőséggel bír számára, mint az adott időpillanatban tapasztalt látvány kínálta élmény átélése. Ez utóbbi viselkedésmód egy lehetséges magyarázata lehet annak a jelenségnek is, hogy mértéktelen módon duzzad az emberi élet (jelentéktelen) állomásait rögzítő képek száma. Az ember dokumentáló lénnyé lett, sorsa egy vizuális portfólió.

\section{II.3.3. A kép mint tapasztalati forrás}

Arra a kérdésre, hogy miért vált mindennapi szükségletté a kép, a tapasztalat irányából is közelíthetünk. Egyfelől meg kell vizsgálnunk, hogy a média mint tapasztalatszerzési forrás 
mennyire teszi szükségessé a képek számának növekedését és az egyén vizuális dokumentációképzését, másfelől fel kell vetnünk a kérdést: például a nyaralás egy adott időpillanatában megtapasztalt dolgok, és ezek fotón történt rögzítése milyen viszonyban áll a valósággal? Egyáltalán: két különböző valóságról beszélhetünk-e?

Szimptomatikusnak tekinthető, hogy napjaink embere egyre inkább elszakad a természettől, nem ismeri testközelből a természeti elemeket és jelenségeket. Tapasztalatai egyre nagyobb hányadát a képek teremtette másodlagos valóságból, a médiatérből szerzi. A médiumok a test meghosszabbításaiként, prosztéziseiként müködnek, ezáltal az érzékelésnek új dimenzióit nyitják meg: kiterjesztik a testi érzékelés és észlelés határait. ${ }^{289} \mathrm{E}$ kiterjesztés ugyanakkor paradox módon egyfajta elzárást is jelent egyúttal. Hogy egy banális példával világítsuk meg a problémát: a modern, városi ember rendszeresen fogyaszt csirkehúst, ám az élő csirkéről alig van személyes, empirikus tapasztalata. A mai felnőttek egy része is már csak képeskönyvekből ismerte meg ezt az állatot, a most felnövő gyerekek pedig többnyire digitális képeken és mozgóképsorokon látják először, sokáig talán fel sem fedezve az összefüggést az elfogyasztott hús és a képernyőn látott lény között. Ám mivel a valóságban az embernek mondjuk egy urbánus környezetben - nincs alkalma csirkével találkozni, rá van utalva a képekre, azok alapvető szükségletévé válnak, mert csak azok révén képes megismerni az őt körülvevő világot. Ezzel ugyan nagy mértékben megnőtt a félreismerés kockázata, de mivel sok esetben nincs más opció, így kénytelen vállalni azt.

A gondolatmenetet persze meg is lehetne fordítani: talán nem arról van szó, hogy a tapasztalatszerzési, megismerési lehetőségek hagyományos útjainak elzáródása miatt van szükség a képekre, hanem arról, hogy a képek áradata elfedte a tapasztalatszerzés hagyományos módjait. Hogy melyik jelenség az ok, és melyik az okozat, nehéz megítélni, a média teremtette mesterséges környezet problémái azonban régóta foglalkoztatják a gondolkodókat, és létrejött egy dualisztikus megközelítésmód, a valóságot és a médiavalóságot ontológiailag elválasztó kettősség.

Walter Lippmann már 1922-ben, Public opinion ${ }^{290}$ címü munkájában hangot adott annak az elképzelésének, hogy korának világa elérhetetlen, átláthatatlan és elgondolhatatlan, így az emberek egyes cselekedetei nem a való világból szerzett közvetlen és biztos ismereteken, hanem másoktól kapott elképzeléseken alapulnak, így „az emberek elméjében élő képek nem

\footnotetext{
${ }^{289}$ V.ö.: Tarnay László: Az új médiumok és a test prosztetikus dimenziói. In: Antalóczy Tímea (szerk.): Határtalan médiakultúra. Wolters Kluwer, Budapest, 2015. 180.

${ }^{290}$ Lippmann, Walter: Public Opinion. New York, Harcourt, Brace and Co. 1922.
} 
felelnek meg automatikusan a külvilágnak."291 Lippmann a közvélemény és az újságok kapcsolatáról írt, ám a Rivers - Mathews szerzőpáros 1988-ban ${ }^{292}$ rávilágított arra, hogy koncepciója kiterjeszthető minden tömegmédiára. „A tömegmédiákra úgy tekinthetünk, mint amelyek álkörnyezetet iktatnak az ember és az »igazi« világ közé.” - írják. Úgy vélik, ez a fajta leegyszerüsített, vulgáris, az átlagember számára felfogható és használható világ azonban mesterséges burokkal veszi körül az embert és betüremkedik a közösség uralkodó kultúrájának értékrendjébe, nézeteibe. ${ }^{293}$ E gondolatok publikálása óta már sokan beszélnek megkettőzöttségről: a valóságos környezet mellett, amely az elmúlt évezredek folyamán körülvette az embert, megjelent ez a bizonyos másodlagos vagy pszeudo-világ is. (Használatos a virtuális valóság elnevezés is, noha e fogalomnak számos, egymástól egészen eltérő értelmezése létezik. ${ }^{294}$ )

Ez a pszeudo-világ elsőre sokkal biztonságosabbnak tünik, hiszen bebarangolásához ki sem kell mozdulnunk otthonunkból. Ha azonban jobban megvizsgáljuk, nyilvánvaló, hogy éppúgy tele van veszélyekkel és agresszióval, mint a „hús-vér” világ - ám ezekkel egyelöre még nem tudunk mit kezdeni. A pszeudo-világ, a virtuális világ jelenségei nem sodornak bennünket közvetlen életveszélybe, rövid távon nem érezzük a hatásukat, ezért az olyan reakciók, mint a menekülés, a védekezés vagy a szembeszállás - többnyire elmaradnak. Látjuk a ránk szegeződő pisztolycsövet, a felénk száguldó vonatot, az ugrásra kész, vicsorgó oroszlánt, az utcán felénk rohanó zombit, de meg sem rezzenünk, hiszen tudjuk, hogy ez csak illúzió. A játékokban meghalunk és feltámadunk, hiszen több életünk is van. A híradóban bemutatott bűncselekményekről, terrorakciókról, balesetekről ugyan tudjuk, hogy a valóságban történtek, de ezek sem érintenek meg bennünket különösebben, hiszen egy-egy nap számos ilyet látunk. Ösztöneink épp ezért nem késztetnek semmilyen válaszreakcióra. Az információszerzés, a tapasztalatszerzés és a kapcsolatépítés szempontból viszont próbáljuk erre a világra is a „valós” élet szabályait alkalmazni, és úgy mozogni benne, mint ha a „valódiban” lennénk.

\footnotetext{
${ }^{291}$ Lippmann. Walter: A külvilág az elménkben. In: Angelusz - Tardos - Terestyéni (szerk.): Média, nyilvánosság, közvélemény. Gondolat Kiadó, Budapest, 2007. 103.

${ }^{292}$ Rivers, William L. - Mathews, Cleve: Ethics for the Media. Prentice-Hall, 1988.

${ }^{293}$ Rivers, William L. - Mathews, Cleve: Médiaetika. (Ford.: Jánossy Ilona). Bagolyvár Kiadó, Budapest, 1993. 30 .

${ }^{294}$ Mivel a virtuális szó jelentése látszólagos, nem valóságos, lehetséges, ezért a szóösszetételben két, egymásnak ellentmondó fogalom kerül egymás mellé. Eredeti, technikai-digitális értelmében számítógépes technikával létrehozott szimulációt jelent, de jelentése kitágult, létezik egy filozófiai-szellemtörténeti értelmezése is: sokan a média teremtette másodlagos környezetként azonosítják. V.ö.: Fehér Katalin: A virtuális valóság elmélete és gyakorlata. In: Médiakutató, 2003. nyár
} 
Az új médiamonopólium címü művében ${ }^{295}$ Ben H. Bagdikian így ír: „Korunkban mindenki két világban él. Az egyik a természetes, hús-vér világ, amely a Homo sapiens megjelenése óta körülveszi az embereket." ${ }^{" 296}$ Ebben a világban az ember végtelenül összetett variációkban, szemtől szemben kerül kapcsolatba más emberi lényekkel, és e találkozások során kialakult ösztönök befolyása alatt áll. „A másik világ, amelyben napjainkban a legtöbb ember él, a tömegmédia világa. Az emberi történelemhez mérve e világ új és szokatlan.” Bagdikian szerint az ember ebben a világban is megpróbálja a jelenségeket úgy kezelni, mint azt a hús-vér világban tenné. ${ }^{297}$

Lippmann és Bagdikian gondolataival sok tekintetben összecsengenek Roger Silverstone meglátásai is, aki szerint ,,arra is használjuk a médiaszövegeket, hogy elkerüljük a világot, távol tartsuk tőle magunkat..." ${ }^{298}$ A brit médiatudós úgy véli, azért is nehéz többek között a médiaelmélettel foglalkozók dolga, mert ők maguk sem tudnak kilépni a média világán kívülre, hiszen ez a kutatók médiavilága is, és a médiáról szóló diskurzus is része ennek a világnak. $^{299}$

Ha azonban nem tudunk kilépni a média világán kívülre, felmerül a kérdés, hogy van-e értelme a duális megközelítésnek, a valóság és a másodlagos, média teremtette valóság szétválasztásának és e két szféra hierarchikus viszonyba állításának. A duális elmélet a tapasztalatok különbözőségére épít: a másodlagos valóságban, a pszeudo-világban szerzett tapasztalatok a közvetlen empíriával szemben csupán közvetettek, így hitelességük kétségbe vonható. A média az „,olyan, mintha” érzetét kelti - olyan, mintha ott lennénk a helyszínen, olyan, mintha a saját szemünkkel látnánk a dolgokat. Ám a média világában valójában nem mi látunk, hanem helyettünk látnak, nem aktív, hanem passzív megismerő tevékenységet folytatunk. (Bár látni fogjuk, hogy e megállapítások az újmédiára nem mindig érvényesek.)

Stefan Weber azonban felvet egy új, nem-dualisztikus megközelítést, amelyben a valóság és a médiaelméleti írások egységét tételezi. ${ }^{300}$ A már többször hivatkozott Flusser, és a szociológiai rendszerelméletet ${ }^{301}$ megalkotó Niklas Luhmann meglátásaival is számos ponton összecseng az a gondolata, mely szerint a valóságnak nincs és nem is lehet végső és minden

\footnotetext{
${ }^{295}$ Ez a mü az 1983-as The Media Monopoly című munka bővített, átdolgozott változata (Boston, Beacon Press, 1983.)

${ }^{296}$ Bagdikian, Ben H.: Az új médiamonopólium. Fordította: Müller Ákos. Budapest, CompLex Kiadó, 2012. 11.

${ }^{297}$ U.o.

${ }^{298}$ Silverstone, Roger: Miért van szükség a média tanulmányozására? Akadémiai kiadó, Budapest, 2008. 28.

299 U.o. 29.

${ }^{300}$ Weber, Stefan: Non-dualististische Medientheorie. Eine philosopische Grundlegung. UVK, Konstanz, 2005.

${ }^{301}$ E rendszerelmélet értelmében a társadalom nem egyének halmaza, hanem zártkörü kommunikációs folyamat. Önreferenciális szociális müveletek sorát tapasztaljuk, vagyis ebben a kommunikációban a rendszerek csak belső müveleteikből indulnak ki, noha kognitívan nyitottak. Ld.: Niklas Luhmann: Systemtheorie, Evolutionstheorie und Kommunikationstheorie. In: Soziologische Gids. 22/3. 1975. 154-168.
} 
eszköztől független leírása. Tóth Benedek ebböl kiindulva fogalmaz úgy, hogy „a valóság csakis leírásaiban létezik." A leírások (és ez bizonyára a leképezésekről is elmondható) nem a valóságról szólnak, hanem ők maguk a valóság. Az újabb és újabb leírások átalakítják és változtatják a valóságot. ${ }^{302}$ James W. Carey pedig úgy fogalmaz: a kommunikáció „egy szimbolikus folyamatként értelmezhető, ami által létrehozzuk, fenntartjuk, módosítjuk és átalakítjuk a valóságot." ${ }^{303}$

Baudrillard valóság-felfogása is non-duális, noha végkicsengése - a szimulákrumokban való eltünés, a valóság és képe közötti különbség megszünése, a két szint megkülönböztethetetlensége $e^{304}$ - jóval pesszimistább. Azt állítja, nincs többé média olyan értelemben, mint a valóság két állapota közötti közvetítő erö. Egyik pólus beolvad a másikba, rövidzárlat keletkezik a jelentésrendszerben, a jelentés összeomlik. ${ }^{305}$ Eltünik a különbség médium és valóság között, így megszűnik a közvetítés lehetősége is. ${ }^{306}$

A nem-duális megközelítéssel szorosan összefüggnek a média jellegének, valósághoz való viszonyának változásai, melyek figyelembevétele nélkül a kérdés megítélése lehetetlenné válik. A médiumokat gyakran csoportosítják szerkezetük szerint. Ez alapján az egyik csoportba sorolhatók a középpont köré szerveződő csillag ábrájával leírható, hagyományosnak is nevezett, broadcasting-típusú szerkezettel rendelkező, diskurzív, tranzaktív, lineáris narrációt megvalósító médiumok (nyomtatott sajtó, rádió, televízió), amelyek az információk közvetítésére és archiválására alkalmasak. Esetükben a feladó és a befogadó szerepe nem cserélhető fel. A másik csoport a középpont nélküli hálózat szerkezetével bíró, interaktív, reflektív, dialogikus médiumok csoportja, amelyet az „újmédia” kifejezéssel is illetnek, noha bele sorolhatók a hagyományos posta- és telefonrendszerek is, mint az internet bizonyos értelemben vett előzményei. És ide tartozik természetesen az internet, amely nem az első dialogikus médium, viszont az első olyan, amelyik - Tóth Benedek szerint - technikailag is megtestesít egy olyan szemantikát, amely magát a dialogicitást mint alapelvet kódolja és deklarálja. ${ }^{307}$ Ezek nem rögzítik a feladói és befogadói szerepeket, és képesek arra, hogy a meglévő információkból újakat szintetizáljanak. Dan Gillmor az első csoportra az előadás

\footnotetext{
${ }^{302}$ Tóth Benedek: Médiumok és valóságaik. MTA Bölcsészettudományi Kutatóközpont, Budapest, 2014. 152.

${ }^{303}$ Carey, James W.: Communication as Culture. Essays on Media and Society. New York \& London, Routledge, 1994. 23-24. Idézi: Tasnádi Róbert: Miről szólnak a képek? In: Médiakutató, 2012 tél.

${ }^{304}$ Ld.: Baudrillard, Jean: A szimulákrum elsőbbsége. In: Kiss Attila, Kovács Sándor, Odorics Ferenc (szerk.): Testes könyv I., Ictus / JATE Irodalomelmélet Csoport, Szeged, 1996.

${ }^{305}$ Baudrillard ezalatt azt érti, hogy, „ahol az információ látszólag jelentést hoz létre, ott valójában éppen az ellenkezője történik. Az információ felfalja önnön tartalmát. Felemészti a kommunikációt és a társadalmit.” Ld.: Baudrillard, Jean: A jelentés összeomlása a médiában. In: Angelusz Róbert, Tardos Róbert, Terestyéni Tamás (szerk.): Média, nyilvánosság, közvélemény. Gondolat Kiadó, Budapest, 2007. 144.

306 U.o. 146.

${ }^{307}$ Tóth Benedek: Médiumok és valóságaik. MTA Bölcsészettudományi Kutatóközpont, Budapest, 2014. 150.
} 
(lecture) metaforáját használja, a másodikra pedig a szemináriumét (seminar), ${ }^{308}$ de leírhatók a csatorna illetve a képernyő metaforájával is. E szerkezeti átállás pedig számos új kérdést felvet, többek között a fikció és valóság fogalmának szétválasztása kapcsán.

Niklas Luhmann 1995-ben megjelent könyvében, A tömegmédia valóságában (Die Realität der Massenmedien) ezt az új tapasztalati terepet veti alá részletes vizsgálatnak, és egy paradoxont igyekszik tisztázni. Eszerint „,manipulációt gyanítunk, ez azonban nem vezet említésre méltó következményekhez, mivel a tömegmédiából szerzett tudás mintegy magától önmegerősítő szövedékké áll össze. Minden tudást a kétségbevonhatóság előjelével látunk el és mégis építünk rá, igazodnunk kell hozzá." ${ }^{309}$ Luhmann a tömegmédia valóságos valóságának egyfelől a bennük zajló, rajtuk keresztülfutó kommunikációkat tekinti, másfelől felhívja a figyelmet arra az értelmezésre, mely afelől közelít, hogy a tömegmédia számára vagy általa mások számára mi mutatkozik valóságnak. Kanti nyelven szólva azt mondja: a tömegmédia transzcendentális illúziót teremt, és a tömegmédia tevékenységét megfigyelő műveletek sorozatának is tekinthetjük. ${ }^{310}$

Tudomást kell vennünk tehát arról, hogy a különbség az empirikusan hozzáférhető világ és a média róla szóló leírásai között egyre inkább instabillá válik, hiszen a média világának, e másodlagos valóságnak az alakításában is részt veszünk, hatással vagyunk milyenségére. Míg a diskurzív médiumok esetében lehetőségeink kimerültek abban, hogy befogadhattuk a közvetített információt, (olykor kétes hitelességü) tapasztalatokat és tudást szerezhettünk belöle, a dialogikus médiumok világában kiléphetünk e passzív befogadó szerepből, és a dialógusok (melyek lehetnek természetesen képiek is) révén a valóság új elemeit hozzuk létre. Ezen elemek ugyan nem egy empirikusan megismerhető közegben, hanem egy virtuális térben keletkeznek, de valós voltuk kétségbe vonása egyre több problémába ütközik.

Tóth Benedek szerint elmondható, hogy a társadalomnak a média formájában kifejeződő kultúrája, vagyis önleírásának alapszerkezete egy duális jelfogalomról átáll egy nem duális szerkezetre. Mivel ez a jelfelfogás számos területen meghatározó, így újra kell gondolnunk a realitás és fikció, az objektivitás és szubjektivitás, a valóság és médiavalóság feloszthatóságát. „A technikai képek szemantikájának elsődleges hatása az imagináció egyre teljesebbé válása, vagyis az önreferencialitás felé mozdulás.” A technika láthatóvá válik, a konstrukció mozzanata egyre alapvetőbb része bármiféle leírásnak, a transzparencia véglegesen elveszik, valóság és médiavalóság viszonyának rendje felborul, végső soron megváltozik a valóság

\footnotetext{
${ }^{308}$ Gillmor, Dan: We the media. Grassroots Journalism by the People. O'Reilly, 2004.

${ }^{309}$ Luhmann, Niklas: A tömegmédia valósága. Gondolat - AKTI, Budapest, 2008. 9.

${ }^{310}$ Tóth Benedek: Médiumok és valóságaik. MTA Bölcsészettudományi Kutatóközpont, Budapest, 2014. 150.
} 
megtapasztalhatósága. ${ }^{311}$ Mit jelent mindez a képekre nézve? Hogyan függ össze a vizuális dokumentációképzéssel?

Az előzőekben azt láttuk, hogy a médiauniverzum bármely szereplője lehet adó és befogadó, szerepeit tetszőlegesen cserélgetheti, ily módon nem csak egy közvetített lét, egy másodlagos valóság befogadója, hanem aktívan munkálkodik a valóság új elemeinek létrehozásán, oly módon, hogy meglévő információkból újakat szintetizál. A hagyományos például egy nyaralásról készült, előhívatott, albumban elhelyezett - fotográfia esetében e szintetizáló folyamat nem hangsúlyos. ${ }^{312}$ Nem új információk létrehozása a cél, hanem az, hogy valamit archiváljunk a jövő számára. A közösségi oldalon publikált nyaralós fotó viszont - ha nem is túl hosszú ideig, de néhány napig biztosan - önálló életet él, új valóságelemeket konstruál, amennyiben dialógusra hív másokat, akik hozzászólnak, hozzáadják saját képeiket, esetleg valamiféle szerkesztésnek vagy manipulációnak vetik alá azt. A fotó készítője és szereplője (a kettő egyre gyakrabban ugyanaz a személy) ezáltal egy valóság-konstrukcióban vesz részt. Képe által jelen van egy másik térben is, és a kép révén interakcióba lép másokkal.

Azt továbbra is megállapíthatjuk, hogy e konstrukció két síkon zajlik. Képünk készítőszereplője ott van a tengerparton, ahol történnek vele az események, találkozik emberekkel, dialógusokat folytat, tehát létének szövete konstruálódik. Mindeközben, ebből a létből kikilépve kezébe veszi a telefonját, és belép a másik síkra, ahol szintén történnek vele események, találkozik emberekkel, dialógusokat folytat. Azt azonban nem jelenthetjük ki teljes bizonyossággal, hogy az előző valóság valóságosabb, a másik pedig csak másodlagos, ál, hamis, pszeudo-jellegü. A tény, hogy jóval kevésbé mozgunk benne otthonosan, mint az évezredek óra megszokott előző síkon, arra ösztönöz, hogy ne fogadjuk el ugyanolyan valóságnak mint a másikat. (Egy alapos kételynek persze munkálnia kell bennünk, amely tovább lendít a téma tanulmányozásában, és segít felkészülni a változásokra.) De nem szabad elvetnünk annak a lehetőségét, hogy nem kell két valóságról beszélnünk, hanem egy és ugyanazon valóság két síkjáról, két terepéről. E két terep továbbra is összevethető, a bennük tapasztalható folyamatok, kommunikációs és tapasztalatszerzési formák különbségeit lehet és szükséges is vizsgálatoknak vetni alá.

\footnotetext{
${ }^{311}$ U.o. 151.

${ }^{312}$ Meglétének egyértelmű tagadása mégsem indokolt, hiszen azáltal, ahogy egy személy a képeket elhelyezi az albumban, valamiféle konstruáló-szintetizáló tevékenységet azért végez.
} 


\section{A fejezet összegzése: Az emberi életút mint vizuális portfólió}

Vilém Flusser gondolatából kiindulva - mely szerint a technikai kép ${ }^{313}$ feltalálásával a kultúra és maga az emberi lét is kezdi alapvetően megváltoztatni a struktúráját - annak próbáltam a nyomába eredni, hogy a fotográfia feltalálása, illetve az ahhoz vezető szellemi folyamatok hogyan képezhették kiindulópontját az emberi életet folyamatosan leképező vizuális dokumentációgenerálás folyamatának. E vizsgálat során az ember és kép viszonyában bekövetkező változásokra összpontosítottam, kiindulva az első fejezetben már taglalt, a szemlélő pozícióját érintő elmozdulásokból. Ezen változások vezetnek ahhoz a lényegi módosuláshoz, amely a kép emberre gyakorolt hatásában tapasztalható. A XX. század végére ugyanis már nem a képtől a szemlélöre visszaható élmény áll e hatás középpontjában, hanem maga a(z empirikus tapasztalat helyére benyomuló) kép. Ennek egyik oka a fotográfiának az a tulajdonsága, amely látszólag nem-szimbolikus, objektív karaktert kölcsönöz neki, és a nézőt arra indítja, hogy ne képnek, hanem ablaknak lássa azt. E szemléletmód azonban figyelmen kívül hagyja azt a tényt, hogy a fotó egy apparátus programját teljesíti be, tehát nem lehet meghatározottságoktól mentes.

Ahhoz, hogy eljussunk a napjainkra jellemző állapotig, melyben az emberi élet folyamatos képi dokumentálásnak van kitéve, szükség volt azokra a lehetőségekre, amelyeket a digitális fotó feltalálása teremtett meg. E találmány révén nem csak a mennyiségi képkészítés elöl hárultak el az akadályok, hanem egy új helyzetet is teremtett, amelyben nem létezik kész kép, csupán képváltozatok. A redundancia mint tünet már korábban is jellemezte a fotózást, de ezzel válik igazán meghatározóvá: minden apró elmozdulás vagy változás újabb kép elkészítésére ösztönöz.

A redundáns vizuális dokumentációképzés felé vezető út tüneteként regisztrálható a nyilvánosságnak szánt, „,profi” fotók és a privátfotók közötti határvonal elmosódása, amely szintúgy annak a következménye, hogy a kép képtárgyi létéből tiszta információvá alakult. Ez tette ugyanis lehetővé a képek gyors ütemű mediatizálódását, melynek a során a tárolási aktus helyett a publikálási aktus vált hangsúlyossá. A képek egyre kevésbé az utókornak és a jövőnek készülnek, hanem egyre inkább a jelennek. Az olyan bensőséges pillanatok ábrázolása, mint egy családi ünnep, a szülö-gyermek vagy a párkapcsolati viszony meghitt jelenetei már nem csupán egy szük kör figyelmére tartanak igényt, és sorsukat nem azzal teljesítik be, hogy egy

\footnotetext{
${ }^{313}$ A technikai kép - „technischen Bilder” - Vilém Flussernél a gépi közremüködéssel készült képeket jelenti, szemben azzal a felfogással, amely szerint minden ember alkotta kép technikai kép.
} 
albumban megőriznek valamit az utókor számára. Céljuk az, hogy egy jóval szélesebb nézőközönség előtt, egy kiterjesztett jelenben demonstráljanak egy létállapotot. E demonstráció pedig mind gyakrabban és gyakrabban történik, és nem gátolja az a tény sem, hogy közben alig történik változás, az ábrázolt állapotok nem térnek el jelentősen egymástól - tehát a képek redundánsak, igazából nincs új téma, nincs merőben új információ.

A vizuális portfóliók tehát egyrészt olyan képekből állnak, amelyeket az egyén készít valami másról, hozzá tartozó vagy nem hozzá tartozó személyekről, tárgyakról, állatokról, növényekről, vagy pedig olyan helyszínekről, amelyeken ott járt. Másrészt olyan képekből, amelyek őt magát ábrázolják, amiket vagy másokkal készíttet, vagy önmagáról készít (selfie).

Az újmédia és a web 2.0 világa tökéletes terepnek bizonyul a képi meghatározottság mind szorosabbá válásához. Ettől elválaszthatatlan kísérő jelenség a vizuális infláció, a képek értékvesztésének folyamata, melynek egyik oka a körülöttünk lévő képek mennyiségének növekedése, másik oka pedig az, hogy a képeket elfedi a megszokás. A XXI. század elején az ember nem csupán a képektől függ, hanem a mindig megújuló képektől! A képek állandó cserélődéséhez szokott hozzá, amely nélkül már nehezen tudja elképzelni életét. E folyamatos megújulás, a képi környezet állandó változása iránti igény sajátos dinamikát ad a létnek a posztfotografikus korban. (A buszmegállókban és a házfalakon cserélődő reklámposzterek változásába keveseknek van beleszólása, ám a telefonok, tabletek, számítógépek háttérképeit, a közösségi oldalakon használt profilképeket, a személyre szabható, változtatható színü és mintájú chat-háttereket vagy az email-fiók arculatát azonban mindenki saját maga cseréli le újra és újra. Emögött természetesen nem csak a változás és a dinamika iránti igény fedezhető fel, hanem a szabad választás illúziójának varázsa is.)

A képek változnak és cserélődnek körülöttünk, noha e cserék ritkán hoznak figyelemreméltóan új információkat, újszerü tartalmakat - így képi mivoltukban nem hívják fel magukra a figyelmet. Nem a képek, hanem a képek hiánya az, ami feltűnő. Egy-egy kép tehát már nem tud igazán nagy hatást elérni, az ember mégis ragaszkodik hozzájuk, kapaszkodik beléjük, a létrehozás aktusa szükségletként van jelen mind többek életében. E szükségletet táplálhatja az freud-i drive, amely a szemlélésben és a szemlélve levésben mint gyönyörforrásban nyilvánul meg. Ennek megélése könnyebbé vált a digitális fotótechnika és az újmédia megjelenésével.

Arra a kérdésre, hogy az egy adott időpillanatban megélhető látvány élvezete helyett miért választják egyre többen azt, hogy inkább annak rögzítésével foglalkozzanak, többféle válasz adható. Az egyik az, hogy a világot digitális kijelzőn át néző ember nincs is tudatában annak, hogy lemarad valamiről, vagy úgy gondolja, az élmény bepótolható utólag, a képek 
megtekintése által. De egy olyan magyarázat is lehetséges, amely az önazonosság képlékenységében ragadható meg, és abból indul ki, hogy egy kapaszkodóit veszített ember számára fontosabb az, hogy mások is érzékeljék, amit ő. Szüksége van a visszajelzésekre, a reakciókra, amelyek segítenek neki annak meghatározásában, hogy miként viszonyuljon az érzékelt, látott dologhoz.

A képek szükségességének megértéséhez a tapasztalat irányából is közelíthetünk, hiszen a természeti világ helyett egyre inkább a képek biztosítják a tapasztalatszerzési forrást. Ennek kapcsán felvetődik a kérdés, vajon beszélhetünk-e a valóság megkettőződéséről, és a média teremtette másodlagos valóságról, pszeudo-valóságról? Ennek megválaszolásához fontos megkülönböztetnünk a diskurzív, tranzaktív és a dialogikus, interaktív médiumokat. Utóbbiak hatóterében az empirikusan hozzáférhető világ és a média róla szóló leírásai között instabillá válik a különbség, hiszen e leírásokat magunk alakítjuk. Kilépünk a passzív befogadó szerepből, és valóság-konstrukcióban veszünk részt. Az így konstruálódó valóság-elemek ugyan egy virtuális térben keletkeznek, de valós voltuk kétségbe vonása problémákba ütközik. Tehát nem feltétlenül kell két valóságról beszélnünk, hanem egy és ugyanazon valóság két síkjáról, két terepéről, melyek átjárhatók, vagy párhuzamosan megélhetők. A médiatérben konstruálódó valóságnak és az eköré szerveződő kommunikációnak fontos elemei a képek. Ez is indokolja az igyekezetet, amely az egyén által közvetlenül megtapasztalt dolgok azonnali leképezését sürgeti - és egyre duzzasztja a sorsát reprezentáló képes portfóliót.

E portfóliók - mint életutat reprezentáló gyüjtemények - létrehozása általában nem tudatos és nem szándékos, hiszen ahogy láttuk, már elsősorban nem a jövőnek, hanem a jelennek készülnek a képek. Ám ettől még a kép egy általános tulajdonsága nem változik, nem szünik meg: a kép megörökít. Elképzelhető persze, hogy elenyészik, tönkremegy, egy idő után megszünik létezni, ugyanakkor az is lehetséges, hogy sokáig betölti a láttatás funkcióját, és ha nem is hat olyan mértékben, mint amikor még csekélyebb volt a technikai képek száma, bizonyos információkat mégiscsak továbbad. Vizuális portfólió alatt tehát azon képek (fotók és videók) összességét értem, amelyeket az egyén létrehoz vagy másokkal önmagáról életre hívattat földi léte folyamán. Az elmúlt két évszázad nemzedékein végigtekintve elmondhatjuk, hogy e portfólió elemeinek száma generációról generációra magasabb, és e tendencia vége még nem látható. 


\section{A képekkel irányított ember}

„Nem csoda, ha elhangzott, hogy olyan történeti korszakba léptünk, amelyben a kép átveszi az irott szó helyét. Ennek a várakozásnak a fényében különösen fontos a kép kommunikációban betöltött lehetöségeinek tisztázása - annak a kérdésnek a megválaszolása, hogy vajon mi az, amit jobban tud, mint a beszélt vagy irott nyelv, és mi az, amit nem. ",314

Gombrich

\section{III.1. A vizuális portfólió elemei mint kommunikációs eszközök}

„[a kép és szöveg] nem perlekedö növérek, hanem inkább egymástól elszakitott szerelmesek, akiket kínoz a talán mindörökre elveszitett eredendö egység iránti vágy. A másikban mindketten saját maguk hiányzó részét keresik. "315

Jacqueline Lichtenstein

Az olyan közösségi oldalak és alkalmazások megjelenésével, amelyek kifejezetten fényképek és videók megosztásán alapulnak, ${ }^{316}$ a képekkel történő kommunikáció új megvilágításba került. Míg régen csak a jelentékeny, addig most a legjelentéktelenebb dolgok is leképeződnek. Az idősebbek rácsodálkoznak, miért kell a vacsorára elfogyasztott hamburgert is lefényképezni, a fiatalok azonban - úgy tünik - a szóbeli vagy írásbeli csevegést és a történetmesélést váltják ki ezekkel a képekkel. Fotókkal mesélik el a médiatér közösségének, hogy merre jártak, mit csináltak. E fotókat sokszor manipulálják, szerkesztik, képi jelekkel, rajzokkal, animációval egészítik ki. A szavak felcserélése képekre bizonyos nézőpontból tekintve rendkívül gyors: míg a kétezres évek első évtizedében az emberek sms-üzenetben közölték a velük egy háztartásban élőkkel, hogy bevásároltak, addig ma lefotózzák a teli szatyrot, és a továbbított képből a másik fél érti, hogy neki már nem kell boltba mennie. Másfelől azt is látnunk kell, hogy a verbalitás nem minden esetben váltható ki képpel.

\footnotetext{
${ }^{314}$ Gombrich, Ernst: The Visual Image. Scientific American, 227. köt., 3. sz., 1972. szept. 82. Fordította és idézi: Nyíri Kristóf: Kép és idő. Magyar Mercurius, Budapest, 2011. 69.

315 Lichtenstein, Jacqueline: The Eloquence of Color. Rhetoric and Painting in the French Classical Age. University of California Press, Berkeley, 1993. 113. Idézi és fordítja: Hornyik Sándor: A képi fordulat és a kritikai ikonológia. Balkon, 2007/11-12.

316 Lásd pl.: Instagram: közösségi hálózat, amelyre a felhasználók fényképeket és videókat tölthetnek fel, amelyeket különböző effektekkel és szürőkkel láthatnak el, majd megoszthatják azokat másokkal. Vagy: Snapchat: okostelefonos képküldő alkalmazás, amely képekkel való társalgásra épül.
} 
A vizuális portfólió jellemzőinek karakterizálása szempontjából azért elengedhetetlen a nyelvi és a képi közvetítés közti különbségek feltérképezése, mert amennyiben valóban afelé haladunk, hogy a képek az emberi kommunikációban (részben) lecserélik a verbális kifejezési formákat, nagy jelentősége lesz annak a kérdésnek, hogy ez hogyan mehet végbe, illetve mi az, ami elveszik, és mi az, ami a helyébe áll?

A továbbiakban vizsgáljuk meg, hogy a vizuális portfólió elemei mennyiben tekinthetők kommunikációs eszköznek, hogyan hatnak ki rájuk azok a dilemmák, amelyek a képkutatásban a kép-szöveg-gondolkodás triáddal kapcsolatosak, majd tekintsük át azokat a problémaköröket, amelyeket ezen képi elemek kommunikációba való behelyezése indukál - kiindulva abból a felfogásból, hogy a kommunikáció nem csupán üzenetátadás, hanem olyan szimbolikus folyamat, amelynek során kultúra jön létre és marad fenn. ${ }^{317}$

\section{III.1.1. A vizuális portfólió elemeinek ismeretátadásra való alkalmassága}

„Nem játunk el teljesen jogosultan, amikor a képek civilizációjának nevezzük korunkat: egyelőre még és minden eddiginél inkább az írás határozza meg ezt a civilizációt"318 - írta Roland Barthes 1964-ben. Reklámokat elemezve jutott arra, hogy még mindig az írás és a beszéd az információs struktúra döntő mozzanatai. Azzal érvelt, hogy a képek önmagukban nem érnék el a céljukat, és beszéd (felirat) nélküli képekkel találkozhatunk ugyan, de csak paradoxonként, bizonyos humoros rajzokon, mivel a beszéd hiánya mindig enigmatikus szándékot jelez. Úgy tünik, azóta sokat változott a helyzet, hiszen a közösségi oldalak tele vannak kommentár nélküli, üzenő célzatú képekkel. Mégsem tudjuk Barthes vélekedését minden kétséget kizáróan cáfolni, hiszen kép és szó egymásnak való megfeleltethetősége közel sem egyértelmü, és régre visszanyúló polémiát generált.

Flusser úgy véli, a szöveget a Kr. előtti második évezredben „találták ki” azért, hogy a képeket „mágiátlanítsák”, bár a feltalálói ennek feltehetően nem voltak a tudatában; a fotográfiát pedig a 19. században találták föl azért, hogy a szöveget újból „mágiával töltsék föl” akkor is, ha a feltalálók ezúttal sem voltak ennek tudatában. Flusser szerint az írással kezdődik el a szükebb értelemben vett történelem, mint harc a képimádás ellen. A fotográfiával pedig elkezdődik a történelem utáni idő, mint harc a szövegimádás ellen. ${ }^{319}$ Flusser gondolata - még

\footnotetext{
${ }^{317}$ Lázár Judit: A kommunikáció tudománya. Budapest, Balassi Kiadó, 2001. 10. (A Charles Cooley, John Dewey, Herbert Mead nevével fémjelzett chicagói iskola hagyományai nyomán összefoglalt megállapítás.)

318 Barthes, Roland: A kép retorikája. In: Blaskó - Margitházi (szerk.): Vizuális kommunikáció. Szöveggyüjtemény. Typotex, Budapest, 2010.

${ }^{319}$ Flusser, Vilém: A fotográfia filozófiája. Tartóshullám - Belvedere - ELTE BTK, Budapest, 1990. 16.
} 
ha leegyszerüsítőnek találjuk is - jól mutatja azt az ellentétet, amely a szöveg és a kép közé feszítve régóta jelen van a gondolkodásban.

A képkutatástól elválaszthatatlan a kép és szó kapcsolatának kutatása, amely az önmagára reflektáló nyugati kultúra narratívájában - legalábbis a 19. századtól - újra és újra tetten érhető. Jellemzi ezt valamiféle küzdelem, vetélkedés is, a felsőbbrendüség elismertetéséért folytatott harc. Az egyik álláspont szerint a kép kezdetleges rendszer a nyelvhez viszonyítva, mások szerint a szavak nem érnek fel a kép kimondhatatlan gazdagságával. Ahogy Eliade fogalmaz: a képek megmutatják mindazt, ami a fogalmi gondolkodásnak ellenáll. ${ }^{320}$

E szembeállítás azonban nem volt mindig jellemző. Gottfried Boehm az ekphraszisz, a képelbeszélés kétezer éves elnevezését hozza példaként (pl. Achilleus pajzsa is ilyen), jelezve, hogy sokáig fel sem merült, hogy a kép és nyelv egymással olyan viszonyba kerülhetnének, amelyben rokonságuk törékeny kapcsolatnak bizonyul. „Csak a 18. század vége óta ébredt fel egyfajta problématudat, amely azóta - különösen az elötérbe nyomult modernek védjegye alatt - megerősödött, sőt, egészen az ellentmondásig s a teljes útvesztésig eljutott." ${ }^{321}$

E folyamat előzményeként érdemes megemlíteni Otto Neurath képnyelv-alkotási kísérletét, aki a '30-as években Gerd Arntz illusztrációit felhasználva, csapatával kidolgozta az Isotype rendszert ${ }^{322}$. Ennek az elsősorban számszerü adatok illusztrálására szolgáló szimbolikus képi rendszernek az elsődleges célja az volt, hogy szociális összefüggéseket ábrázoljon írástudatlanok számára. Az osztrák származású német filozófus munkásságára bizonyára a mesterséges világnyelvek megalkotását célzó (eszperantó, latino sine flexione, interlingua stb.) próbálkozások is hatással voltak, ám ő azt szerette volna elérni, hogy a képzetlenek és az analfabéták számára is elérhető legyen egy univerzális zsargon. Neurath Isotype-ja erős hatást gyakorolt egyrészt a későbbi hasonló rendszerekre - például a kartográfiai szimbolikára vagy a mai információs grafikákra - másrészt arra a későbbi vitára, amely a képek és a szavak kijelentéstartalmak szemléltetésére való alkalmasságáról szólt és szól. ${ }^{323}$

A Boehm által is jelzett, képeket és szavakat szembeállító polémia másik kiindulópontját Wittgenstein képekre vonatkoztatható kijelentései adják, hiszen a szakirodalomban komoly vitákat váltott ki a könyveit és vázlatait mintegy 1300 képpel

\footnotetext{
${ }^{320}$ Eliade, Mircea: Képek és jelképek. Európa Kiadó, Budapest, 1977. 24.

${ }^{321}$ Boehm, Gottfried: A képleírás. A kép és a nyelv határairól. (ford.: Rózsahegyi Edit) In: Tomka Beáta (szerk.): Narratívák I. Képleírás - képi elbeszélés. Kijárat, Budapest, 1998. 19.

${ }^{322}$ Lásd: Neurath, Otto: Bildstatistik nach Wiener Methode in der Schule. Deutscher Verlag für Jugend und Volk, Wien/ Leipzig 1933. és Neurath, Otto: International Picture Language. Kegan Paul, London 1936.

${ }^{323}$ V.ö: Roser, Andreas: Léteznek-e autonóm képek? Észrevételek Otto Neurath és Ludwig Wittgenstein grafikus munkáihoz. In: Neumer Katalin (szerk.): Kép, beszéd, irás. Gondolat, Budapest, 2003.
} 
illusztráló Wittgenstein korai és késői képfelfogásának szembeállíthatósága. Gyakorta idézik kiindulópontként a Filozófiai vizsgálódások 115. paragrafusát: „Egy kép tartott fogva bennünket. És nem tudtunk szabadulni tőle, hiszen benne rejlett a nyelvünkben, és úgy látszott, nyelvünk csak ezt ismétli kérlelhetetlenül."324 Bizonyos nézőpontból úgy tünhet, hogy Wittgenstein a képeket alacsonyabb rendünek gondolta és úgy tekintett rájuk, mintha azok csak a nyelvbe ágyazott használat és kontextus révén nyernék el értelmüket, ám vannak, akik ezt vitatják, például a Barna könyv arckifejezésekkel kapcsolatos részére ${ }^{325}$ hivatkozva, ahol a filozófus arra utal, hogy egy rajzolt arckifejezés milyensége nem feltétlenül adható vissza szavakkal. Ugyanakkor Wittgenstein célja nyilvánvalóan nem a szavak és képek értékének összevetése volt, inkább a fogalmi megragadhatóság feltárása. Képfelfogásának értelmezéstörténetét Nyíri Kristóf ${ }^{326}$ Virgil C. Aldrich, Gombrich, Anthony Kenny, Søren Kjørup, Baruch Blich, Mitchell és Boehm meglátásain keresztül világítja meg, ${ }^{327}$ láttatva egyúttal azt is, milyen élénk vitairodalmat generáltak Wittgenstein képekkel kapcsolatos meglátásai. Úgy véli, ,az 1990-es évek derekára éppenséggel széles körben kibontakozhatott volna annak a tudata, hogy a késői Wittgenstein nem csak a szónyelv, de a képek filozófusa is volt. Ám nem bontakozott ki." ${ }^{328}$ Nyíri ebben Mitchell felelősségére is rámutat, aki többek között Wittgenstein ikonofóbiájában és a nyelvfilozófia vizuális reprezentációval kapcsolatos szorongásában látja annak jelét, hogy képi fordulat zajlik. Ezzel szemben Gottfried Boehm írja Nyíri - az általa ikonikus fordulatnak nevezett váltást éppenséggel a késői Wittgenstein munkássága következményének látja, s úgy véli, ő mutatta meg a nyelvi fordulatból visszafelé vezetö utat. ${ }^{329}$

Mint köztudott, W.J.T. Mitchell Richard Rorty linguistic turn-je nyomán alkotta meg a pictorial turn fogalmát, ${ }^{330}$ melyet 1994-es tanulmányában fejtett ki. Mitchell ebben nem húz analógiát nyelv és kép közé, inkább azt hangsúlyozza, hogy a vizuális műveltséget nem lehet teljesen a textualitás modellje alapján magyarázni. Regisztrálja, hogy a kép mint téma

\footnotetext{
${ }^{324}$ Wittgenstein, Ludwig: Filozófiai vizsgálódások. (ford.: Neumer Katalin) Atlantisz, 1992., 115. § 80.

${ }^{325}$ Wittgenstein, Ludwig: The Brown Book. 162.

${ }^{326}$ Ö maga sokáig úgy vélte, Wittgensteinnek jelentős felismerései voltak a képekkel kapcsolatban, ezek azonban nem állnak össze a képek egységes filozófiájává. (Lásd: Nyíri Kristóf: A gondolkodás képelmélete. In: Neumer Katalin (szerk.): Kép, beszéd, irás. Gondolat, Budapest, 2003.) Későbbi kötetében álláspontját felülvizsgálja és kiegészíti azzal, hogy Wittgenstein fö problémája az volt, hogy a metaforára és a képekre vonatkozó gondolatait nem sikerült összhangba hoznia. (Lásd: Nyíri Kristóf: Kép és idő. Magyar Mercurius, Budapest, 2011. 48-56.

${ }^{327}$ Nyíri Kristóf: $A$ gondolkodás képelmélete. In: Neumer Katalin (szerk.): Kép, beszéd, irás. Gondolat, Budapest, 2003. Valamint: Nyíri Kristóf: Kép és idő. Magyar Mercurius, Budapest, 2011. 31-42.

${ }^{328}$ Nyíri Kristóf: Kép és idő. Magyar Mercurius, Budapest, 2011. 41.

${ }^{329}$ U.o.

${ }^{330}$ Mitchell, W.J.T.: Pictorial turn. In: Picture Theory. The University of Chicago Press. Chicago, IL, United States, 1994., 11.
} 
napjainkban úgy emelkedik ki a bölcsészettudományokból, mint a nyelv tette nemrégen, ugyanakkor feltámadt az igény beszédünk védelmére a vizualitással szemben. A képek diszkomfortérzetet, súrlódási pontokat hoznak létre, ikonofóbiát generálnak ${ }^{331}$. Amikor Mitchell képi fordulatról beszél, nem a tünetek, sokkal inkább a hatás felöl közelít: abból látszik, hogy képi fordulat megy végbe, hogy sokan félnek a vizualitás hatalomátvételétől. Hornyik Sándor megfogalmazásában Mitchell „a képi fordulatot nem elsősorban a késő kapitalizmus képrobbanása, hanem a logikai-filozófiai gondolkodás felől definiálja”. ${ }^{332}$

A linguistic turn nyomán a képeket védelmébe vette Hans Belting is, aki egy interjúban így fogalmazott: „Szövegkultúránk vagy teljesen elüzte a képeket, vagy - és ez ugyanolyan ravasz fogás - mủvészetnek nyilvánította, professzionalizálta. Ez azt jelenti, hogy ezután már a művészetben nem a képeket keressük, hanem minden képben a művészetet." ${ }^{333} \mathrm{Az}$ első fejezetben már taglalt, a képek hovatartozásával kapcsolatos problémakör tehát a nyelv-kép viszonyrendszer megítélésével is szorosan összefügg.

Ahogy arról korábban szintén szó volt, Mitchell bevezette a kép/szöveg (image/text) kifejezést, demonstrálva a képek és szavak elválaszthatatlanságát, hiszen kép és szöveg a történelem folyamán mindig is szoros összefonódásban létezett. Felveti azt a lehetőséget, hogy teremthetünk nekik egy közös platformot, amely új utakat nyit a téma vizsgálatában. ${ }^{334}$ Érdekesség, hogy majdnem 20 évvel Mitchell Pictorial turn-je előtt, 1975-ben Horányi Özséb publikált egy tanulmányt Adalékok a vizuális szöveg elméletéhez ${ }^{335}$ címmel, amelyben hasonló témát fejteget. Kísérletében kifejti: semmi sem indokolja, hogy az eredendően ugyan nyelvészeti fogalom, a szöveg elemzését csakis nyelvi anyagon, illetve az irodalomra korlátozva végezzük. A szemiotika oldaláról nézve a legelemibb, legkisebb elem is vizsgálható szövegként, a kódtól a szöveget egyedül a bennük lévő rendszer érvényessége különbözteti meg. Amíg a kód a jelölő egy meghatározott szerveződési szintjén érvényes rendszer, és a szövegek egész csoportjára érvényes, addig a szöveg rendszere egyedi, tehát csak partikulárisan érvényes. Ha ez igaz, akkor viszont nemcsak vizuális nyelvről, de vizuális szövegről is indokolt beszélni!

\footnotetext{
${ }^{331}$ Mitchell, W.J.T: A képi fordulat. In: Szőnyi György Endre - Szauter Dóra: A képek politikája. W.J.T. Mitchell válogatott írásai. Jate Press, Szeged, 2012. 133.

${ }^{332}$ Hornyik Sándor: Idegenek egy bünös városban. Müvészettörténetek és vizuális kultúrák. L’Harmattan - MTA Müvészettörténeti Kutatóintézet, Budapest, 2011. 91.

${ }^{333}$ Az 1996-os interjú a C3 Alapítvány oldalán olvasható:

http://www.c3.hu/ tillmann/konyvek/ezredvegi/belting.html (letöltés: 2017.09.21.)

${ }^{334}$ Mitchell, W.J.T.: Picture Theory, essays on Verbal and Visual Representation. Chicago: University of Chicago Press, 1994.

${ }^{335}$ Horányi Özséb: Adalékok a vizuális szöveg elméletéhez. In: Általános Nyelvészeti Tanulmányok XI. (szerk.: Telegdi Zsigmond - Szépe György) Budapest, Akadémiai Kiadó, 1975. 144-146.
} 
Ugyanakkor, a XX. század végén megjelentek azok a vélekedések is, melyek szerint a képek nem fordíthatók le a verbális nyelvre, ahogy a verbális nyelv által elmondottak sem közölhetők egyértelműen a képek nyelvén. Boehm iconic turn-je olyan interpretációs kísérleti eljárás, amely az autonóm, nem-referenciális képiség feltárására vállalkozik, pragmatikus teorémaként azt a célt kitüzve, hogy a képet megmentse az inflálódástól.

Varga Emőke az illusztrációkutatás nézőpontjából, három paradigma - szemiotika, strukturalizmusok és hermeneutika - vonatkozásában tekinti át a kép és szöveg viszonyának reflexiótörténetét. Fontosnak tartja Kandinszkij szemiotikai-formalista alapú kísérletét - amely a képi jeleknek (pont, vonal, sík) és a képi kompozícióknak mint a nyelvi jelek és nyelvi struktúrák analógjainak megközelítésére és definiálására irányult - szembeállítva Sol Worth vizsgálatával, aki szerint a képek a nyelvvel nem ekvivalensen strukturálódnak, nincs nyelvtanuk, de bizonyos hasonlóságokat struktúra, forma, konvenció és szabályok vonatkozásában találhatunk. ${ }^{336}$ Varga Emőke felhívja a figyelmet a szennyezettség problémájára, mely abból indul ki, hogy két kifejezésmód közötti váltáskor mindig keletkezik valamilyen zörej, és elkerülhetetlen, hogy ne legyen valamilyen különbség a szöveges illetve a képi megjelenítés között. ${ }^{337}$ Rámutat, hogy a Panofsky-féle interpretációs eljárás (melyről az I.3. fejezetben már volt szó) feltételként foglalja magába a képek textuális eredetét, míg az elsősorban német kutatókat megmozgató képhermeneutika „felhagy a szemiotikai strukturalizmus képolvasási stratégiáival, elutasítja a nyelvnek alárendelt, a nyelv függvényében létező képfelfogást."338

A kép és a szó viszonyának szakirodalma egyre duzzad, hiszen a hétköznapi ember szintjén is észlelhető az a jelenség, hogy az egyén egyre szívesebben használja a képet saját önkifejezési céljaira. Mi sem jelzi ezt jobban, mint az, hogy a kézitáskák, zsebek elmaradhatatlan tartozéka immár nem a toll vagy a ceruza, hanem a képek készítésére alkalmas okostelefon. Egyelőre nehéz megítélni, hogy a képekkel való kommunikáció mennyire sikeres a szavakkal való kommunikációhoz képest, vagy minden esetben kiválthatja-e egyik a másikat, ám az eltolódás kétségtelen. E képi önkifejezés lehetővé válásához nyilvánvalóan szükség volt az arra alkalmas technika elterjedésére, vagyis arra, hogy csaknem minden ember a birtokában legyen a képek készítésére, továbbítására és megtekintésére alkalmas eszközöknek, amelyek minden pillanatban hozzáférhetők. Ezáltal az egyén biztatást és támogatást kap ahhoz, hogy tovább és tovább növelje saját képi dokumentumainak halmazát, képekkel hozza létre és

\footnotetext{
${ }^{336}$ Varga Emöke: Az illusztráció a teóriában, a kritikában, az oktatásban. L’Harmattan, 2012. 17.

337 U.o. 19.

338 U.o. 22.
} 
mesélje el saját létének történetét. Még a kronológia megtartásához is kap támogatást, hiszen az elkattintott fotók után több alkalmazás felajánlja, hogy 'hozzáadja azt az ember napjához', egyfajta képekből álló naplót hozva létre.

A nyelv és kép viszonyának meghatározása mellett a másik megkerülhetetlen, belőle következő problémakör a jelentés és kép összefüggése, melyről Wittgenstein, Gombrich, Nelson Goodman, ${ }^{339}$ Stephen Kosslyn ${ }^{340}$ és mások alkottak különféle elméleteket. Az egyik álláspont szerint a képek önmagukban nem hordoznak jelentést, csak azáltal tesznek rá szert, hogy a nyelv által meghatározott módon használtatnak, meghatározott kontextusokban kerülnek alkalmazásra - máskülönben ugyanaz a kép két különböző dolgot is jelölhet. ${ }^{341}$ (Wittgenstein példájával: a lejtőn felfelé igyekvő és a lejtőn lefelé csúszó ember képe nem különbözik. ${ }^{342}$ De hasonlót fejteget Gombrich is egy pompeji ház bejáratának kutya-mozaikját elemezve, utalva arra, hogy ha azon nem szerepelne a ,C Cave canem” felirat, akkor nem biztos, hogy betöltené funkcióját. ${ }^{343}$ ) Nyíri Kristóf erre reflektálva $A$ gondolkodás képelmélete címü tanulmányában arra hívja fel a figyelmet, hogy maguk a mentális képek is inkább dinamikus, mint statikus természetüek, a mozdulatlan mentális képek pedig lehetnek dinamikus képek határesetei. ${ }^{344}$ Nyíri felhívja a figyelmet H.H. Price felismerésére is, mely szerint a képek együttese vagy időbeli sorozata egyértelmü jelentést hordozhat ott, ahol az egyes kép sokértelmü. ${ }^{345} \mathrm{Ha}$ figyelembe vesszük, hogy az internetes közösségi oldalakon egy-egy dologról gyakran több, különböző szemszögből vagy különböző fázisban készült képet szoktak publikálni, illetve egyre gyakoribb, hogy rövid mozgóképes anyagot tesznek közzé, a képek többértelműsége mint a képekkel való kommunikáció sikerének ellenérve, gyengülni látszik.

A képi kommunikáció sikerességében szerepe lehet az idő elörehaladásának is. Søren Kjørup arra mutat rá, hogy míg a verbális nyelvet az ember létezése óta szüntelenül használja és finomítja, addig a kommunikációra alkalmas képek a nyomtatás feltalálása előtt ritkaságszámba mentek. ${ }^{346}$ (Ezzel kapcsolatban érdemes figyelembe venni W.M. Ivins 1952-

\footnotetext{
${ }^{339}$ V.ö: Goodman, Nelson: Az újraalkotott valóságról és a képek hangjáról. In: Horányi Özséb (szerk.): A sokarcú kép. Typotex, 2003.

${ }^{340}$ V.ö.: Kosslyn, Stephen: Image and Brain. MIT Press, 1994.

341 A késői Wittgenstein gondolatait összegzi ily módon Nyíri Kristóf A gondolkodás képelmélete c. tanulmányában.

${ }^{342}$ Wittgenstein, Ludwig: Filozófiai vizsgálódások. Atlantisz, 1992., 140.§/(b), 89.

${ }^{343}$ Gombrich, E.H.: A látható kép. In: Horányi Özséb: Kommunikáció I-II. Budapest, General Press, 2003. 94.

${ }^{344}$ Nyíri Kristóf: A gondolkodás képelmélete. In: Neumer Katalin (szerk.): Kép, beszéd, irás. Gondolat, Budapest, 2003. 266.

${ }^{345}$ Price, H.H.: Thinking and Experience. Hutchinson's Universal Library, London, 1953. 252. Idézi: Nyíri Kristóf A gondolkodás képelmélete c. tanulmányában.

${ }^{346}$ Kjørup, Søren: George Innes és a Hastingsi csata, avagy hogyan tegyük képpel. In: Horányi Özséb (szerk.): A sokarcú kép. Typotex, Budapest, 2003. 337.
} 
ben publikált gondolatait, aki felhívja a figyelmet arra, hogy míg a könyvnyomtatásnak nagy jelentőséget tulajdonítunk, addig a kép- és ábranyomtatás valamivel korábban felfedezett módozatairól hajlamosak vagyunk megfeledkezni. Míg rögzített szógyüjtemények Gutenberg előtt is léteztek, a képnyomtatás valami gyökeresen újat hozott: a kép pontos megismételhetőségét, amely felbecsülhetetlen hatást gyakorolt a tudásra, tudományra, gondolkodásra. ${ }^{347}$ ) Kjørup gondolatához csatlakozik Nyíri Kristóf is azzal a feltételezésével, miszerint a mentális képalkotás képessége ma ismét növekedőben van. Úgy véli, „az emberek kezdik magukat otthonosan érezni a képek körében, a képekkel való tevés-vevés olyan gazdag tapasztalatára tesznek szert, amely példátlan az írott történelemben.” Kiegészíti ezt azzal, hogy a könnyű képalkotás lehetőségét, a képi kommunikáció egyre mindennaposabbá válását korunk számítógépes alkalmazásai is tovább gerjesztik. Szerinte tehát a képek nyelve ma mind jobban alkalmassá válik az elvont-gondolati kommunikációra. ${ }^{348}$ Nyíri Kristóf azonban egy későbbi, 2011-es kötetében árnyalja saját álláspontját, és csatlakozik Gombrich gondolatmenetéhez, ${ }^{349}$ kimondva, hogy a képek jelentéshiányosak, és csak a mozgókép teljesértékü jelentéshordozó; az állókép logikai kifejezőkészsége korlátozott, a képsorozat, a képek egymásutánja, az animáció és a mozgókép viszont nem csak rögzít, megmutat, konzervál, de érvel is. ${ }^{350}$

Kibédi Varga Áron azonban - megkülönböztetve a vizuális argumentáció és a vizuális narrativitás fogalmát - arra hívja fel a figyelmet, hogy az egyedi állókép is képes érvelni. Úgy véli, egy kép tartozhat az epideiktikus nemhez, és ,,szándékosan készíthetik úgy, hogy a néző csodálatát és lelkesültségét felébressze az iránt, amit ábrázol”, de tartozhat a deliberatív nemhez is, amikor közvetlen ösztönző jelleggel bír, „,a nézőt felszólítja, hogy meghatározott érzéseket hagyjon kifejlődni magában, sőt, ezeket esetleg tetteibe is ültesse át."351

Kibédi a szó-és-kép viszonyok (,,word-and-image relations, ${ }^{352}$ ) területén regisztrál egy módszertani és egy rendszertani problémát. A módszertanit annak a kérdése jelenti, hogy vajon egymás mellé állíthatók-e nyelvi és képi artefaktumok? Átvihetők-e az egyik területén alkalmazott módszerek a másikra? A rendszertani pedig a jelenségek változatosságából fakad

\footnotetext{
${ }^{347}$ Ivins, W.M. Jr.: A nyomtatott kép és a vizuális kommunikáció. Enciklopédia Kiadó, 2001.

${ }^{348}$ Nyíri Kristóf: A gondolkodás képelmélete. In: Neumer Katalin (szerk.): Kép, beszéd, irás. Gondolat, Budapest, 2003. 276

${ }^{349}$ Gombrich képelméletét többnyire az 1960-ban megjelent Art and Illusion című kötetéből (magyarul: Müvészet és illúzió, Gondolat, Budapest, 1972.) vezetik le, pedig fontos adalékokkal egészíti ki saját nézeteit későbbi, '70es-'80-as években megjelent tanulmányaiban. The Visual Image című munkájában (Scientific American, 1972/09) teszi például azt a fontos megállapítást, hogy a kép olvasásának esélyei három változón múlnak: kód, képfelirat, kontextus.

${ }^{350}$ Nyíri Kristóf: Kép és idő. Magyar Mercurius, Budapest, 2011. 57. és 169.

${ }^{351}$ Kibédi Varga Áron: Vizuális argumentáció és vizuális narrativitás. In: Athenaeum, 1993. I./4. 169.

352 Kibédi Varga Áron: Criteria for describing Word-and-Image relations. Somlyó Bálint fordításában megjelent: Bacsó Béla (szerk.): Kép, fenomén, valóság. Kijárat, 1997. 300-320.
} 
- ezt orvosolandó kísérletet tesz egy osztályozásra, melynek során elválasztja e viszonyok tárgyi- és metaszintjét. Arra a következtetésre jut, hogy a tárgyi szinten, ${ }^{353}$ vagyis a dolgok: vizuális és szóbeli artefaktumok szintjén az értelmezés a jellemző - s e tény bizonyos értelemben a fordítás lehetetlenségének beismerése. „Az értelmező sosem pontos fordító: válogat és ítél." 354 Ám a metaszinten, a kommentárok, a viszonyok és relációk szintjén, az artefaktumokkal kritikailag foglalkozó szövegek világában elérhető a fordítás, vagyis a képek szavaknak való megfeleltethetősége. 355

Ugyanakkor Kibédi szerint a modern médiumok azt tanúsítják, hogy sok autonóm képtörténet létezhet, melyeknek a szövegét soha nem fejtik ki teljesen. „Ahol a képeknek prioritásuk van és kiindulópontul szolgálnak, ott a nézők aktív fantáziájában történetek alakulnak ki, amelyeket verbális formában pontosan nem rögzítenek." ${ }^{356}$ De figyelmeztet arra is, hogy „az ilyen képtörténetek autonómiája csak addig tart, ameddig el nem mesélik őket."357

A narrativitásra és az érvelésre vonatkozóan nyilvánvalóan vannak különbségek és fokozatok a Kibédi által monoszcenikusnak nevezett, vagyis csak egy jelenetet ábrázoló, egyedi állókép és annak pluroszcenikus változata ${ }^{358}$ között, valamint a képsor, illetve a mozgókép között. Ám ha napjaink mediatizált képvilágát tekintjük, azt láthatjuk, hogy már nem válnak élesen szét a különféle kategóriákba sorolható képek. Lev Manovich úgy véli, a posztdigitális vizuális mezőben hibrid képek jönnek létre. Szerinte az 1990-es évek közepétől a mozgó- és állóképgyártás szimulált fizikai médiumai és az új digitális médiumok interakcióba kerültek a köznapi, számítógépes környezettel. A kézzel rajzolt képek, a kivágott fotók, videók, nyomtatott és 3D-s elemek nem csak egymás mellett helyezkednek el, hanem még egymásba is olvadnak. „Az így keletkező vizuális nyelv a hibrid, amit metanyelvnek is nevezhetünk, mivel egyesíti a dizájn, a könyvnyomtatás, a cel-animáció, a 3D-s számítógépes animáció, a festészet és a filmipar nyelvét." ${ }^{359}$ Manovich úgy véli, az ilyen hibrid képek valószínűleg nagy szerepet játszanak majd a jövő vizuális kultúrájában, míg a „tiszta”, nem kevert, természetes képek valószínűleg veszítenek jelentőségükből. ${ }^{360}$

\footnotetext{
${ }^{353}$ Kibédi a tárgyi szinten belül időbeli, mennyiségi és formai kritériumokat állít fel, megkülönböztet egyidejü és egymást követő szó-és-kép viszonyokat, külön vizsgálja az egyedi képeket és a sorozatokat, utóbbin belül a rögzített és a mozgó képeket.

${ }^{354}$ Kibédi Varga Áron: A szó-és-kép viszonyok leirásának ismérvei. In: Bacsó Béla (szerk.): Kép, fenomén, valóság. Kijárat, 1997. 311.

${ }^{355}$ U.o. 318.

${ }^{356}$ Kibédi Varga Áron: Vizuális argumentáció és vizuális narrativitás. In: Athenaeum, 1993. I./4. 176.

357 U.o.

${ }^{358}$ U.o. 170.

${ }^{359}$ Manovich, Lev: Jövő-kép. In: Gerencsér Péter (szerk.): Új, média, müvészet. SzatírIKON könyvek, Universitas Szeged Kiadó, 2008. 90.

${ }^{360}$ U.o.
} 
Ha a táguló vizuális portfóliókat tekintjük, azt láthatjuk, hogy ezek nagy arányban tartalmaznak képsorozatokat és mozgóképeket. Nem ritka, sőt, egyre inkább jellemző, hogy a közösségi oldalakra egy eseményről több fotó is felkerül, még selfie-sorozatokat is láthatunk, melyek egy helyszín több pontját megmutatják. Bizonyos funkciók lehetővé teszik, hogy különböző személyek ugyanazon helyszínen vagy eseményen készült fotóit összegyüjtve szemléljük meg, az ún. hashtag-ekkel ${ }^{361}$ pedig azonosíthatók, kategorizálhatók a jelenségek. Növekszik bennük a mozgóképsorok, telefonnal rögzített videók száma is. Gyakori, hogy szerkesztett, grafikus elemekkel bővített fotókat látunk, melyek a Manovich által jelzett hibriditás felé mutatnak. E portfólió-elemek kifejezőkészsége tehát ily módon jóval kevésbé korlátozott, mint egy régi, családi album elemeié.

A képek hibriditása mellett figyelembe kell vennünk a korunkra jellemző multimedialitást is, vagyis azt a tényt, hogy a médiumok jellemzően egyszerre több csatornát és jelrendszert használnak: álló és mozgóképet, hangot, írott szöveget. A legnépszerübb médiatartalmak - a játékfilmek, filmsorozatok, tv-müsorok, vlogok - ilyenek. A multimedialitás jelensége tehát bizonyos tekintetben ellentmond annak a víziónak, hogy a szavak képekre való felcserélésének folyamatában vagyunk. Az emberi percepció és a gondolkodás kezdőpontjainak tekintett érzékszervi alapú tudattartalmak, a képek mellett ugyanis elevenen hat az akusztikus-szimbolikus jelrendszer, a nyelv. Bár a tapasztalat teljességében való megragadására a nyelv sem képes, ám hangzó és írott formájában egyaránt rugalmas.

A vizuális portfóliók kommunikációra való alkalmasságához kapcsolódóan tehát egy változástényezőt regisztrálhatunk: a tünetek azt mutatják, hogy egyre többen egyre több információt próbálnak a képek útján közölni - bár ez nem feltétlenül korlátozza a verbalitás jelenlétét, legalábbis a szóbeli, hangzó kommunikáció szintjén. Nem jelenthetjük ki egyértelműen sem azt, hogy a vizuális portfóliók elemei nem alkalmasak önmagukban való, szöveges kiegészítés nélküli, objektív jelentéshordozásra, de azt sem, hogy a helyzet már tökéletesen megérett arra, hogy véglegesen átvegyék a szavak - vagy legalábbis a leírt szavak - helyét. (Bár itt eszünkbe juthat Flusser víziója, miszerint ahol a képek dominálnak, ott az analfabetizmus új pozícióba kerül. „Ha sikerülne a jövőben a szövegeket tökéletesen alávetni a

\footnotetext{
361 A „hashtag” a hash, vagyis a kettőskereszt (\#) jele, amelyet egyfajta metaadatként használnak. Általában közösségi hálókon illesztik a felhasználók egy-egy szó vagy kifejezés elé. Ezzel kategorizálják a megjelölt tartalmat. A jelölt szóra kulcsszóként rá lehet keresni, így megtekinthető, hogy mások milyen tartalmakat osztottak meg ugyanazzal a megjelöléssel.
} 
képeknek, akkor általános analfabétizmusra számíthatnánk, és már csak a specialisták tanulnának írni."362)

Amennyiben a technikai képekkel való kommunikáció sikerességét egy elöremutató folyamatnak fogjuk fel, akkor be kell látnunk, hogy e folyamatnak még nem tartunk a végén ha egyáltalán feltételezhető benne egy végpont vagy csúcspont. Ebből pedig az következik, hogy e kommunikáció metódusai még kiforratlanok, számos problémával, nehézséggel küzdenek. Ezek közül vesz számba néhányat a következő alfejezet.

\section{III.1.2. A vizuális portfóliók általi kommunikáció dilemmái}

A képi kommunikáció előtérbe kerülésének pozitív hatásai között szokás említeni, hogy az egyetemes és nemzetközi, eltünnek a nyelvi akadályok, hiszen a képeket nációtól és nyelvtudástól függetlenül bárki értelmezheti. A képi kommunikáció nem ismeri a nyelv, a szókincs vagy a nyelvtan korlátait, írástudatlanok és müvelt emberek egyaránt sikeresek lehetnek benne. Kepes György úgy véli, ,,a látás nyelve mint optikai kommunikáció, az egyik leghatékonyabb eszköz ahhoz, hogy újra létrehozza az ember és a tudás harmonikus egységét. A vizuális nyelv minden más kommunikációs eszköznél hatékonyabban képes a tudást terjeszteni." ${ }^{363}$ De vajon valóban nincsenek korlátok? Megoszlanak a vélemények azt illetően, hogy a képek nyelve valóban egyetemes-e, vagy a kulturális különbségek itt is megzavarhatják az információátvitelt. Sokan felvetik, hogy a képekkel való sikeres kommunikációhoz szükséges a képi jelek ismerete és egyfajta vizuális müveltség: Antik Sándor szerint a verbális kommunikációs rendszerekhez hasonlóan, ahol az információ megszervezése és üzenetté alakítása igényel egy bizonyos fokú rendszerismeretet és nyelvi tapasztalatot, ugyanúgy a képi közlés is feltételez egy bizonyos fokú tudást és gyakorlatot. ${ }^{364}$

E tudás mibenlétének megközelítéséhez kulcsfogalom lehet a mentális képalkotási képesség és a képi gondolkodás. A vizuális neveléssel foglalkozó szakemberek a képiség előtérbe kerülésétől, az aktuális jelenségektől függetlenül is hangsúlyozzák, hogy a képi gondolkodás fejlesztése fontos része a kognitív gondolkodás fejlesztésének, ezért a gyermekkori rajzolás nem csupán a manuális és vizuális kompetenciákat tökéletesíti, de az általános értelmi képességek kialakítására is jótékonyan hat. Rudolf Arnheim az érzékelés és az absztrakt gondolkodás egységét hangsúlyozza, és a képi gondolkodást a vizuális műveletek

\footnotetext{
${ }^{362}$ Flusser, Vilém: A fotográfia filozófiája. Tartóshullám, Budapest, 1990. 50.

${ }^{363}$ Kepes György: A látás nyelve. Gondolat Kiadó, Budapest, 1979., 6.

${ }^{364}$ Antik Sándor: Vizuális megismerés és kommunikáció. Egyetemi Műhely Kiadó, Bolyai Társaság, Kolozsvár, 2010., 41.
} 
révén történő gondolkodásként definiálja. Vélekedése szerint, ha az „érzékek anyaga” nem marad jelen, az elmének nincsen mivel gondolkodnia, tehát a fogalmi gondolkodásnak is a mentális képek jelentik az elsődleges közegét. ${ }^{365}$ De mi történik, ha az érzékek anyaga, a külvilágból érkező jelek egy jelentős része már eleve fizikai képek formájában manifesztálódik? Mennyire határozza ez meg a fogalmi gondolkodást?

Kepes György úgy véli, hogy a képi gondolkodás a külvilágból érkező jeleket strukturálja és értelmes dologgá alakítja." ${ }^{366}$ Egy adott vizuális kép befogadása egyúttal azt is jelenti, hogy a szemlélő szintetizálási folyamatban vesz részt: „Az érzékelt kép tapasztalása egyúttal alkotó integrációs tevékenység. Lényeges ismérve, hogy az alakítóképesség szerves egésszé formálja a tapasztalatot." ${ }^{367}$ Mennyiben változik meg ez az integrációs tevékenység, ha az érzékelt kép nem élettani, hanem fizikai, és ez szolgál alapjául a mentális képek kialakításának? Nem sérül-e így a mentális képek kialakításának képessége?

Korábban már volt róla szó, hogy az image szóval a képet mint mentális képet, ábrázolást, megtestesítést, szimbolizálást, visszatükrözést, képzetet illetik. Mircea Eliade az etimológia nyomába eredve bemutatja, hogy az imagináció/imagination szó az imago-ból származik (jelentése: elképzelés, imitáció), de rokon az imitor szóval is, ami annyit tesz: utánozni, reprodukálni. Eliade szerint az etimológia egybevág a pszichológia tényeivel: a képzelet a példa értékủ modelleket, a képeket utánozza, reprodukálja. ${ }^{368}$ (A magyar nyelv etimológiája is beszédes, hiszen a kép és a képzelet szó azonos szótővel bír.) Eliade úgy véli: a képzelet az embernek lényegi és elidegeníthetetlen része, képzelőerővel rendelkezni annyit jelent, mint a világot a maga teljességében látni. „Mert a Képek hatalma és küldetése éppen abban áll, hogy megmutassa mindazt, ami a fogalmi gondolkodásnak ellenáll." ${ }^{\text {369 }}$

Egyre többször merül fel azonban az aggodalom, hogy a külső képek (ezek alatt általában a technikai képek és elsősorban a mozgóképek értendők) gátolhatják a belső (mentális) képek megképzését. Ennek egyik tünete az olvasási szokások megváltozásában azonosítható: az információszerzési célú olvasással töltött idő ugyan nem csökken, sőt, de szépirodalmat, történeteket, leírásokat egyre kevesebbet olvasnak az emberek - az egyik lehetséges magyarázat szerint azért, mert azokat egyre kevesebben képesek élvezni. Ehhez ugyanis szükség van az ún. belsö mozira: ha az olvasó képzeletében nem állnak össze képek arról, amit olvas, ha nem tudja elképzelni a szereplőket, helyszíneket, jelenségeket, akkor

\footnotetext{
365 Arnheim, Rudolf: Visual Thinking. University of California Press, 1969. 105.

${ }^{366}$ Kepes György: A látás nyelve. Gondolat Kiadó, Budapest, 1979., 7.

${ }^{367}$ U.o.

${ }^{368}$ Eliade, Mircea: Képek és jelképek. Európa könyvkiadó, Budapest, 1997. 24.

${ }^{369}$ U.o.
} 
szükségszerüen csökken az élvezeti érték - hiszen mint láttuk (II.3.1. fejezet), a képek élvezetet tudnak nyújtani. E fantáziasorvadás okaként a pszichológusok a nagy mennyiségben készen kapott fizikai képeket okolják, amelyek önmagukban is kielégítik az egyén vizuális élvezet iránti igényeit. ${ }^{370}$

A probléma gyökerei az artikulált és az artikulálatlan tudás különbségéig nyúlnak vissza, hiszen a képek az utóbbi birodalmába tartoznak. Polányi Mihály megkülönbözteti az állatokra is jellemző, nem verbalizálható, intuitív, artikulálatlan tudást, és az artikulált tudást, melyhez absztrahálni, formalizálni, szimbolizálni és linearizálni kell. Polányi szerint az emberi gondolkodás evolúciós szempontból egyedülálló és gyors fejlődése a tagolás és artikulálás képességének köszönhető. ${ }^{371}$ Gondolatmenetéből kiviláglik, hogy a nyelvi kommunikáció összetettebb agymüködést igényel, mint a képi. Amennyiben a vizuális jellegü tudás- és tényanyagok kommunikálása megszünteti az artikulációs kényszert, akkor felmerülhet annak a lehetősége is, hogy ez visszafordítja a fejlődési folyamatot, vagy legalábbis a képek közegében, azok verbalitáshoz képesti túlsúlyának hatása alatt felnövő gyermek bizonyos képességei nem kapnak kellő támogatást a kifejlődéshez.

A képzelőerőre gyakorolt esetleges negatív hatás már a mozgókép elterjedésekor aggodalmat váltott ki például Theodor Adornoból, aki arról ír, hogy az illúziókeltő színházat túlszárnyaló film nem hagy teret a néző gondolatainak és fantáziájának, így az életet tendenciájában alig lehet megkülönböztetni a hangosfilmtől. ${ }^{372}$ Duhamel pedig egyenesen úgy fogalmaz: „már nem tudom azt gondolni, amit gondolni akarok. A mozgóképek foglalták el a gondolataim helyét." 373

Csejtei Dezső felhívja a figyelmet arra, hogy a video szó abból a szógyökből ered, melyből az európai kultúra hajnalán Platón a gondolati kép filozófiai szakterminusát, az ideát megalkotta, így az európai civilizáció története majdan akár Az ideától a videóig címet is viselhetné. ${ }^{374}$ Csejtei szimptomatikusnak látja azt az elgondolást, hogy a képi látás eszközapparátusának jelenlegi mértékủ eluralkodása a vizuális fantázia megbénulásához vezet, hisz szükségtelen bármit is elképzelnünk, ha azt közvetlenül magunk elött látjuk. „Az elképzelés, az alkotó fantázia pedig lényeges szellemi tényező, valahol a tiszta, fogalmi

\footnotetext{
${ }^{370}$ Lásd a Tévé elött - védtelenül? c. kötet tanulmányait. Szerkesztette: Szávai Ilona. Pont Kiadó, Budapest, 2010.

371 Polányi Mihály: Személyes tudás I. Atlantisz, 1994.128-154.

372 Adorno, Theodor: A kultúripar. In: Max Horkheimer - Theodor W. Adorno: A felvilágosodás dialektikája. Filozófiai töredékek. Gondolat - Atlantisz - Medvetánc, Budapest, 1990. 153.

${ }^{373}$ Duhamel, Georges: Scènes de la vie future. Párizs, 1930. Idézi: Benjamin, Walter: A müalkotás a technikai reprodukálhatóság korában.

${ }^{374}$ Csejtei Dezső: A minőségi élet esélyeiről. In: Csejtei Dezső: Írások Északról és Délszakról. Veszprémi Humán Tudományokért Intézet, Veszprém, 1999. 134.
} 
gondolkodás és a képi látás között helyezkedik el, feladata pedig épp e két szféra közvetítése, egybekapcsolása lenne.”375 E szellemi tényező háttérbe szorulásának következményeit még nem tudjuk belátni, de ha generációk nőnek fel úgy, hogy képzelőerejük nem tud kifejlődni, az minden bizonnyal súlyos veszteséget jelent az emberiség kultúrájának egészére nézve.

A vizualitás megismerés és értelmezés, módszer és rendszer egy időben - vallja Bálványos Huba és Sánta László, hozzátéve, hogy egy olyan tudati rendszerről, emlék- és ismerethalmazról van szó, amelyben rögzültek és rögzülnek az új látványok, tanulságok és élmények: „ez a rendszer egy alap és egy háló, amellyel várjuk és amelybe nyitott érdeklődéssel fogadjuk és rendszerezzük az új meg új jelenségeket." 376 A mozgókép és a korábban már taglalt vizuális infláció e struktúra kiegyensúlyozott müködésére jelenthet veszélyt, hiszen a hálóban mind több és több kép landol, melyek rendszerezése, értelmezése és szintetizálása a mennyiségi növekedés miatt mind nehezebbé válik.

Tény azonban, hogy minden kommunikációs forradalom hatott egyes emberi képességek és készségek használatára. Az írástudás elterjedése például lehetővé tette a tudás külső tárolását, és ezzel bizonyára óriási hatást gyakorolt a memóriára: ma el sem tudjuk képzelni, milyen mennyiségü információt volt képes fejben tartani az analfabéta ember. Meddő próbálkozás lenne azonban összehasonlítani, hogy a memória vagy a fantázia fontosabb-e a szubjektum szempontjából, melyik részleges hiánya jelent nagyobb fogyatékosságot. Megválaszolhatatlan kérdésként azonban felmerülhet, hogy ha minden kommunikációs forradalommal veszítünk képességeinkből, akkor e tendencia hová vezet, illetve a kommunikációs forradalmak nyeresége arányban áll-e az okozott veszteséggel? Nem zárható ki, hogy a vizuális dokumentációképzés aktusa mögött egyfajta védekező és kompenzáló mechanizmust is felfedezhetünk: képzelőerőnk korlátoltsága miatt mind több és több képre van szükségünk ahhoz, hogy kitöltsük azt az ürt, amely hiányzó mentális képeink helyén keletkezik.

Visszatérve a képekkel való kommunikáció nehézségeihez: az utóbbi évek tapasztalata azt mutatja: a bábeli zürzavar metaforája bátran alkalmazható a napjainkban megnyilvánuló képi kommunikációra is. Az információáramlás sebessége miatt a vizuális jelek, kódok értelmezése a ma embere számára talán még nehezebb, mint elődei számára volt. Mire kitanulnánk egy képi nyelvet, addigra az már el is tünik. A jelek és jelrendszerek egy emberöltőn belül akár többször átalakulnak, így az emberek felnőttként is időröl-időre új, ismeretlen terepen találják magukat. Roland Barthes kétrendbeli jelentés elmélete szerint a

\footnotetext{
375 U.o.

376 Bálványos Huba - Sánta László: A vizuális megismerés és a vizuális kommunikáció. Budapesti Tanítóképző Főiskola, 1996. 95.
} 
jelentésnek van egy elsődleges és egy másodlagos szintje. Az egyik a denotáció: mindaz, amire a jel közvetlenül vonatkozik, egy kép esetében a látható dolgok megjelenítése, a konkrét vizuális elem. A konnotáció pedig a kulturális jelentés, a sugallt jelentés, amely ideológiákat is tükrözhet, illetve mindazokat az asszociációkat, érzéseket, gondolatokat takarja, amelyeket a kép szemlélése a befogadóban felidéz. Barthes szerint a denotáció a folyamat kiindulási szintje, majd a jelentésalkotás átvált a második szintre: itt már a konnotáción van a hangsúly, amely kulturális kódolású. ${ }^{377}$ A jelentésnek ez a szintje tehát kultúrafüggő, dekódolásához szükséges a konnotáció ismerete. Ám ha a konnotáció sokféle lehet, az zavart okozhat a kommunikációban.

Mindezt súlyosbítja, hogy a vizuális kommunikációra a fogyasztói társadalom generálta trendek is rányomják a bélyegüket. Napjainkban például az emberek jelentős része használ hangulatjeleket (más elnevezéssel: emotikon, emoji). A fiatalabb korosztályban szinte sértésnek számít, vagy legalábbis közönyösségre utal, ha valaki egyetlen mosolygó - vagy egyéb kifejezést öltő - arcot, esetleg szív-formát sem ékel be az üzenete szövegébe. E hangulatjelek készlete, milyensége azonban a szolgáltatótól függ, az érzelmi állapotunkról való tudósítás lehetőségei tehát az adott cég kiszolgáltatottjaivá válnak. (Érdekesség, hogy a Messenger alkalmazás hangulatjelei közül - a kétdimenziósról a térbeli jelleget mutató figurákra való áttéréskor - eltűnt az iróniát kifejező, unott tekintetű, nyelvét kinyújtó arcocska. Ez az attitűd, úgy tünik, nem kívánatos a szolgáltató szerint.)

Az emberi arckép státuszának megváltozása kapcsán már volt szó arról, hogy napjaink embere hajlamos bármilyen vizuális jelet magán viselni, ha azt valamelyik divatcég ruházatra nyomtatva kínálja. Az ezredforduló után például gyakori látvány volt a halálfejekkel és szívekkel egyszerre díszített öltözék. Nyilvánvaló, hogy e szimbólumok jelentését felülírta a divat, és az ezt viselő emberek aligha tudták volna megmagyarázni, mit kívánnak közvetíteni a magukon viselt szimbólumokkal és azok kombinálásával. Hasonló a helyzet például a tetoválásokkal is. A szimbólumok, jelképek iránt van ugyan egy felfokozott érdeklődés, ám ez nem tesz különbséget a távolkeleti, az indián vagy éppen a magyar népi motívumok között. Értelmezésüket többnyire az interneten fellelhető sablonos leírásokból próbálják megfejteni, így használatuk közhelyessé válik. Az sem ritka, hogy a több évezredes szimbolikáról tudomást sem véve, csupán dekorációs funkcióban használják őket.

A fent vázolt jelenségek sorát hosszan lehetne folytatni, és mindegyik külön-külön megérne egy elemzést. Jelen esetben azonban csupán annak felmutatása volt a cél, hogy bár

\footnotetext{
${ }^{377}$ Barthes, Roland: A kép retorikája. Filmkultúra 1990/5. 64-72.
} 
egyre többen egyre több információt próbálnak a képek útján közölni, nem szabad megfeledkezünk arról, hogy a gyakorlatban, például a közösségi médiatérben mindennaposak a félreértések a képi kommunikációs aktusokban. Sajnos nem ritkák az olyan történetek sem, melyekben az öngyilkosságot vagy büncselekményt elkövetett egyén internetes profiljában csak utólag fedezik fel a segélykiáltásnak is beillő fotókat, posztokat, melyek időben történő dekódolása megelőzhette volna a tragédiát. ${ }^{378}$ Ezek az esetek ugyan nem csupán a kiforratlan vizuális kommunikáció következményei, hanem a kommunikációs aktus jellegéből is fakadnak: a közzétett posztoknak nincs konkrét címzettje, az azt látók csoportja pedig túl nagy ahhoz, hogy valaki vegye a fáradságot a nem teljesen egyértelmü üzenetek jelentésének értelmezésére. Így megtörténhet, hogy az egyén vizuális portfóliójának utolsó darabját látva a szemlélők nem is sejtik, hogy az illető idővonalán több képet már nem fognak látni.

Elfogadhatjuk tehát Nyíri Kristóf gondolatát, mely szerint a képek nyelve ma mind jobban alkalmassá válhat az elvont-gondolati kommunikációra, de fontos látni azt is, hogy még bőven van tennivaló a vizuális kultúra területén, míg kiforrja magát egy olyan vizuális nyelv, amelyben tudatosabb a jelhasználat és kevesebb a dekódolási probléma - ehhez talán az állóképek és mozgóképek kombinálásával lehet közelebb kerülni, illetve akkor, ha a jelentés közvetítését döntő részben a nem csak demonstrálni, de érvelni is képes képsorozatokra, mozgóképekre bízzuk.

\section{III.2. A vizuális médiában rejlő manipulációs potenciál}

„Nap nap után hullanak ránk a rábeszélés bombasorozatai, és a meggyözés nem érvekkel történik, hanem alapvetö emberi érzelmeinkre ható szimbólumokkal, így hát valóban a rábeszélögép - a propaganda - kora ez. Minden társadalom kialakítja a maga döntési módszereit, a mi társadalmunk a rábeszélést választotta. ",779

Pratkanis \& Aronson

Ahogy a fenti idézet mutatja, Pratkanis és Aronson 1992-ben meghirdetik a propaganda korát, melyben az érveket sokszor képi szimbólumokkal helyettesítik. A „rábeszélőgép” legbensőbb félelmeinkre apellál, kihasználja irracionális reményeinket, hiedelmeinket, ,,átfestvén a világot,

\footnotetext{
${ }^{378}$ Érdekesség, hogy 2017 óta a Facebookon mesterséges intelligencia is megpróbálja detektálni azokat a felhasználókat, akik öngyilkosságra készülhetnek. Lásd: http://hvg.hu/tudomany/20171128_facebook_mesterseges_intelligencia_ongyilkossag

379 Pratkanis, Anthony - Aronsōn, Elliot: A rábeszélögép. Élni és visszaélni a meggyözés mindennapos mesterségével. (ford.: Vámos Miklós) Ab Ovo, Budapest, 1992. 15. (Eredeti cím: Age of Propaganda - The Everiday Use and Abuse of Persuasion. W.H.Freeman and Company, New York and Oxford, 1992.)
} 
amelyben élnünk kell." ${ }^{380}$ A képek használatának történetében tehát megkerülhetetlen az a folyamat, melynek során előtérbe kerül és dominánssá válik a képek rábeszélő funkcióba való állítása, a képekben rejlő manipulációs potenciál kiaknázása.

Az információátviteli folyamat zavarai mellett a modern képi kommunikáció másik óriási problémakörét a manipuláció különböző esetei és azok vetületei alkotják. A manipuláció tudatos befolyásolás, mely révén az üzenet küldője hatni kíván a befogadóra. Ez ugyan minden kommunikációs helyzetre igaz, de „a kifejezés a média világában elsősorban negatív értelemben használatos: a társadalmi tudatformálás etikai értelemben megkérdőjelezhető, olykor kifejezetten nemtelen eszközét értik rajta." ${ }^{381}$

A média befolyásolásra alkalmas eszközeinek tárháza kimeríthetetlen. A legszélsőségesebb eszköz a hazugság, a valótlan állítások közzététele a befogadó megtévesztése céljából. Ez - a cenzúrához és a politikai propagandához hasonlóan - inkább a totalitárius és autoriter médiamodellekre jellemző, hiszen a liberális, a közszolgálati elven alapuló vagy a demokratikus normatív modellekben a direkt hazugság nyilvánvalóvá válása a hitelesség elveszítését vonja maga után. Utóbbi modellekben ezért gyakoribb, hogy a témaválasztással manipulálnak, (hiszen amiről nem számol be a média, az olyan, mint ha meg sem történt volna) vagy a témák nem jelentőségüknek megfelelő súlyozásával, illetve az információ szétdarabolásával, a jelenségek összefüggésekből történő kiemelésével. Kedvelt eszköz a figyelemelterelés (avagy a gumicsont) módszere: ha bizonyos döntéshozók szeretnék egy-egy intézkedésről vagy eseményről elterelni a nyilvánosság figyelmét, ,, bedobnak” valami más, érdekesnek vagy botrányosnak látszó témát, amelyen „,rágódhat” a sajtó, és míg azzal vannak elfoglalva, lecseng a másik téma. Adott még a nézői a sztereotípiákra, elöítéletekre alapozó ún. juxtapozíció, vagyis a kép és az azzal párhuzamosan elhangzó szöveg önkényes társítása. A rezonanciaeffektussal a média egyfajta rezgés-kényszert gerjeszt, amely továbbterjed más médiumokra és a közvéleményre: mivel a média formálta valóságkép sokszor összecseng a mindennapi tapasztalatokkal, a befogadó hajlamos az ismeretlen elemek elfogadására is. Az ún. fóáramlat-hatás pedig valamely vélemény többségi véleményként való megjelenítését takarja: az ennek alávetett befogadó hajlamossá válik a többséginek beállított nézőponttal azonosulni még akkor is, ha az ellentmond a saját tapasztalatainak. ${ }^{382}$

\footnotetext{
${ }^{380}$ U.o. 22.

${ }^{381}$ Film- és médiafogalmak kisszótára. Budapest, Korona Kiadó, 2002. 260-261.

382 Bővebben lásd: Pusztai Virág: Médiaelmélet. Digitális tananyag. VIII./I. fejezet: A médiamanipuláció fogalma, általános eszközei. http://www.jgypk.hu/mentorhalo/tananyag/MediaelmeletV2/ (letöltés: 2017.10.29.)
} 
Az imént sorolt eszközök jól ismert, sokat vizsgált tartalmi megnyilvánulásai a médiaagressziónak. Ezek mellett jóval kisebb hangsúlyt kapnak a kevésbé direkt, de a látásmódunkat hosszútávon befolyásoló, elsősorban a vizualitásban megnyilvánuló eszközök. Az illúzióteremtés igénye természetesen egyidős a mozgóképpel, és a mozi, a filmek világa mindenki számára nyilvánvalóan és burkolatlanul irányítja a néző tekintetét. Ez önmagában nyilvánvalóan nem tekinthető manipulatív megnyilvánulásnak, hisz a néző tisztában van vele, hogy irányítani fogják a figyelmét, azért ül le a vászon, illetve a képernyő elé. Az utóbbi egykét évtizedben azonban jelentősen megváltoztak a médiafogyasztási szokások, a mozgóképek készítése, publikálása és élvezete életmóddá és - ahogy korábban láttuk - elsődleges tapasztalatszerzési forrássá vált. A következőkben tehát érdemes a látás média általi irányíthatóságáról szólni, továbbá azokról az agresszív energiákról, melyek meghatározzák napjaink látáskultúráját.

\section{III.2.1. A látvány befogadásának média teremtette új módozatai}

A média tapasztalatokat meghatározó szerepe már a XX. század elején is sokak számára nyilvánvaló volt. José Ortega y Gasset A tömegek lázadásában leírja, hogy hirtelen megnövekedett a világ és benne az élet is. Arra a következtetésre jut, hogy az élet ténylegesen egyetemessé vált: ,,az átlagember életébe tartalmilag az egész bolygónk beletartozik; és hogy minden egyén már szokásszerűen éli az egész világ életét. (...) Ha a fizika elve szerint a tárgyak ott vannak, ahol hatnak, ma a földkerekség bármely pontján megtapasztalhatjuk a legnyilvánvalóbb mindenütt-jelenvalóságot. A távolinak ez a közelsége, a távollevőnek ez a jelenléte mesés mértékben kiterjesztette életünk látóhatárát." ${ }^{\text {383 }}$ Ortega Y Gasset mindezt 1930ban írja, ekkor már a tömegsajtó időszakában járunk, amikor (a fotóreprodukciókban is bővelkedő) újságok egyre szélesebb rétegekhez jutnak el. A televíziózás még kísérleti stádiumban van, a filmhíradó azonban virágkorát éli. Mindazonáltal az idézett gondolatokat a televíziózás, majd az ún. újmédia elterjedése tette méginkább szemléletessé: a média juttat bennünket tapasztalatokhoz, a média segít nekünk (messzire) látni.

A világ fenti értelemben vett kiszélesedését a tömegmédia tette lehetővé, főként annak vizualitásra építő elemei. Az írott információ - legyen bár mégoly részletes is - az emberi fantáziát kell, hogy igénybe vegye ahhoz, hogy a távoli tárgyak a közvetlen közelünkben is megképződjenek. A fényképek, főként pedig a mozgóképfelvételek azonban élethüen, az

\footnotetext{
${ }^{383}$ José Ortega y Gasset: A tömegek lázadása. Fordította: Scholz László. Budapest, Nagyvilág, 2003. 66-67.
} 
objektivitás érzetét keltve idézik elénk azokat. A ma embere tehát kétféle módon fogadhatja be a látványt: közvetlenül, amikor az adott jelenség ott van előtte, és azt a saját szemével látja, illetve közvetett módon, amikor a jelenség tőle távol zajlik, és a fotós, az operatőr kamerájának lencséjén át látja azt.

A mozgókép-rögzítési eljárások felfedezése, a vizuális média térhódítása előtt az ember csupán a közvetlen környezetéről, a látótávolságán belülre kerülő dolgokról tudott képi információt szerezni. Ha a látótávolságán kívül eső dolgok érdekelték, egész testét, teljes fizikai mivoltát az információszerzés szolgálatába kellett állítania. Helyet kellett változtatnia, hogy az őt érdeklő tárgyak, jelenségek közelébe jusson. Ahogy haladunk a múltból a jelen felé, ez a helyváltoztatás egyre kevesebb időt vett igénybe. A motoros közlekedési eszközök elterjedésével a földrajzi elmozdulás nagyságrendekkel gyorsabban mehetett végbe, így az egységnyi idő alatt begyüjthető vizuális impulzusok száma megnőtt. A mozgókép megjelenése óta pedig már a térben sem kell elmozdulnunk ahhoz, hogy tőlünk távoli vidékek nyújtotta látványvilággal ismerkedjünk. Mióta majdnem minden háztartásban van televíziókészülék, a képi és verbális információk egyaránt az otthonunkba jönnek, a távirányító gombjaival még válogathatunk is közülük. A szervezés, a készülődés, az ábrándozás, az utazás felkészítő előzménye nélkül, pillanatok alatt átugorhatunk (például) egyik kontinensről a másikra. Otthonunk kényelmét élvezve, a fotelből, alkalmasint vacsora közben vagy italt kortyolgatva fogadhatjuk be az olyan vizuális impulzusok milliárdjait, amelyekhez korábban sokkal nagyobb energiakifejtésre volt szükség. A most felnövekvő generáció tagjai pedig már nem csak otthon, a kanapén ülve nézik a mozgóképsorokat, hanem okostelefonjuk, tabletjük segítségével jártukban-keltükben bárhol. Sőt, nem csak befogadják azokat, hanem maguk is napi rendszerességgel készítenek és publikálnak a világhálón rövidebb-hosszabb videóanyagokat, amelyek másoknak szolgálnak tapasztalati forrásul.

Néhány generációval korábban az emberek vizuális értelemben sokkal ingerszegényebb környezetben éltek. Sokan azt sem tudták, milyen látvánnyal, látványosságokkal kecsegtet a szomszédos település. Saját, szükebb környezetüket viszont bizonyos értelemben sokkal behatóbban ismerték, mint a mai ember, hiszen több idejük, energiájuk és agyi kapacitásuk maradt a részletek befogadására, az aprólékos megfigyelésekre. Ismerték a talpuk alatt lévő földet, a csillagok járását a fejük felett, számon tartották a körülöttük sarjadó növények tulajdonságait. Ismereteik testközeli élményeken alapultak, tekintetüket és figyelmüket maguk irányították. A ma embere ezzel szemben más földrészek állatait is ismeri, de ezt az ismeretet a technikai eszközök közvetítik felé. Úgy lát, ahogyan azt a filmfelvételt készítő operatôr kamerájának mozgása meghatározza számára. Ükapáinknak aligha volt alkalmuk például 
zebrát szemlélni, de megvolt a szabadságuk, hogy eldöntsék: jobbról balra, vagy balról jobbra mérik-e végig az állatvásáron a lovat. Ha akartak, közel mentek hozzá, vagy éppen néhány lépéssel eltávolodtak. Mi, kései leszármazottak a számos természetfilmes televíziócsatorna, illetve az interneten elérhető mozgóképes tartalmak révén bármilyen egzotikus állatot megismerhetünk, de csak úgy, ahogyan megmutatják nekünk. A kamera vezeti a szemünket aszerint, hogy jobbról balra svenkel, előre-hátra kocsizik vagy éppen kívülről befelé variózik. ${ }^{384}$ Nem mi irányítjuk a megfigyeléseinket, hanem a mások által diktált iramban és irányban „látunk.” Annyit, amennyi belefér a kamera látómezőjébe, az operatőr által meghatározott látószögbe ${ }^{385}$. Ezt figyelembe véve pedig már nem nevezhetjük egyértelműen valósághűnek és objektívnek azt a képet, amelyet egy technikai eszköz közvetít a számunkra.

Hasonlókat fejteget Walter Benjamin is, noha ő a színészetre vonatkoztatva mutat rá, hogy az apparátus nem alkalmas arra, hogy annak teljesítményét totalitásként fogadja el. Gondolatai azonban kiterjeszthetők a televízióra vagy akár a videomegosztó oldalakon látható, a valóságot megmutatni hivatott mozgóképes anyagokra is. „A készre montírozott filmet az állásfoglalásoknak az a sorozata képezi, melyet a vágó komponál a neki szolgáltatott anyagból. Összefog bizonyos számú mozgásmozzanatot, melyekben a kamera mozgásának mozzanatai ismerhetők fel..."386

Látásunk iránya mellett annak sebességét is meghatározza, megszabja a vizuális média. Mivel termékei a széles tömegek számára készülnek, nem veheti figyelembe az egyéni igényeket. A befogadó nem maga dönti el, hogy mennyi időt tölt el egy-egy tárgy szemlélésével, és mikor lép tovább a következöhöz. Nem maga dönti el, hogy milyen tempóban járatja végig a tekintetét az adott látványelemen, hanem kénytelen alkalmazkodni a felvételt készítő gép, illetve az azt kezelő személy diktálta sebességhez. E sebesség ráadásul egyre fokozódik, hiszen naponta számtalan mozgóképes médiatartalmi egység születik világszerte és küzd meg a befogadók figyelméért. E küzdelem azt eredményezi, hogy egyre több látnivalót, egyre több és ezáltal egyre rövidebb snittet próbálnak ezekbe belekomponálni, gyakran gyors, klip-szerü vágástechnikával, hogy a nézö figyelmét biztosan lekössék, az ne érezze unalmasnak vagy vontatottnak az anyagot. Azonban hiába tesszük ki magunkat vizuális impulzusok millióinak, sem a látószerveink felépítése, sem az agyunk képalkotásért felelős része nem

\footnotetext{
${ }^{384}$ A kameramozgatáshoz kapcsolódó szakkifejezések. Bővebben lásd: Pusztai Virág: A televiziós müsorgyártás és müsorszerkesztés gyakorlati alapjai. Szegedi Egyetemi Kiadó, Juhász Gyula Felsőoktatási Kiadó, Szeged, 2017. 385 Lásd: u.o.

${ }^{386}$ Benjamin, Walter: A müalkotás a technikai reprodukálhatóság korában (ford.: Kurucz Andrea, Mélyi József). VIII. rész http://aura.c3.hu/walter_benjamin.html (letöltés: 2018.02.02.)
} 
változik. Minél több képi impulzust fogadunk be egységnyi idő alatt, ismereteink annál felületesebbek lesznek.

Benjamin a festő és az operatőr összehasonlításakor arra jut, hogy míg előbbi munkája során természetes távolságot tart tárgyával szemben, addig az operatőr mélyen behatol a dolgok szövetébe (akár az operáló sebész). A kettejük által alkotott képek tehát hihetetlenül különböznek. A festő valami totálisat mutat meg, míg az operatőr valami darabokra szabdaltat, és a sok apró rész egy újfajta törvény szerint illeszkedik össze. „Így a mai ember számára a valóság filmbéli ábrázolása azért hasonlíthatatlanul jelentősebb, mert a valóság apparátustól mentes látványát, ami a műalkotásoktól joggal elvárható, éppen az apparátussal történő legintenzívebb áthatás biztosítja." 387

Részletekből szubjektíven összerakott, felületes ismeretekre, részleges, hiányos, kontextusukból kiemelt vagy eltorzult információkra alapozzuk tehát tapasztalataink egy jelentős részét. A kérdés az, vajon mennyire határozza meg a véleményünket, gondolkodásunkat, mindennapi döntéseinket ez a tény?

A nézői pozíciók vizsgálatakor már szóba került Baudrillard szimulákrum-elmélete, amely a manipulációnak egy merőben új szintjét tárja fel, amely megpróbálja egymásba játszani a valóságot a szimulációs modellel. Ez már nem utánzás, nem kettősség, hanem a reálisnak a reális jeleivel való felváltása: a reálist önnön műveleti képmása váltja fel. Míg „a színlelés vagy eltitkolás érintetlenül hagyja a realitás elvét: a különbség mindig világos, csak éppen el van kendőzve. Ezzel szemben a szimuláció megkérdőjelezi az igaz és hamis, valódi és képzeletbeli közötti különbséget" ${ }^{388}$ Ahogy nem lehet különbséget tenni a szimuláns beteg és a valódi között (hiszen valódi tüneteket produkálnak, melyek így is-úgy is kezelésre szorulnak), úgy a szimulákrumról is elmondható, hogy az egyszerre nem igaz és nem hamis. E különbség-nemtételről írja Baudrillard, hogy „ellene fegyverkezett föl a klasszikus gondolkodás az összes kategóriájával, azonban ma ismét ez árasztja el és temeti maga alá az igazságelvet."389

Látásunk meghatározottságának gondolata úgyszintén megjelenik Baudrillard-nál, aki felhívja a figyelmet arra, hogy a mozgóképfelvétel által egy érzéki túlfeszítettségben a jelentéktelen felmagasztosul! Azt látjuk, ami soha nem volt a valóság, ám azon távolság nélkül, ami a térnek perspektívát, látásunknak pedig mélységet ad. ${ }^{390}$

\footnotetext{
${ }^{387}$ Benjamin, Walter: A müalkotás a technikai reprodukálhatóság korában (ford.: Kurucz Andrea, Mélyi József). XI. rész http://aura.c3.hu/walter_benjamin.html (letöltés: 2018.02.02.)

${ }^{388}$ Baudrillard, Jean: A szimulákrum elsőbbsége. (Ford.: Gángó Gábor) In: Kiss Attila, Kovács Sándor, Odorics Ferenc (szerk.): Testes könyv I., Dekon könyvek, Ictus / JATE Irodalomelmélet Csoport, Szeged, 1996. 162.

${ }^{389}$ U.o. 163.

${ }^{390}$ U.o. 182.
} 
Az alfejezet a rábeszélögép hasonlatával indult, Baudrillard viszont a lebeszélögép metaforájával él. „A társadalmi viszony végső stádiumában élünk, ami immár nem a rábeszélésé (ez a propaganda, az ideológia, a reklám klasszikus kora), hanem a lebeszélésé.” (Írja ezt 1981-ben!) Többek között Disneyland-et is lebeszélőgépnek nevezi, ,amit azért állítottak ki, hogy ellenpontként újraélessze a valóság fikcióját." ${ }^{391}$ Disneyland egy harmadik típusú szimuláció: azért van, hogy elleplezze, hogy maga az ország, az egész valódi Amerika nem más, mint Disneyland. Már nem a valóság hamis ábrázolásáról van szó, hanem annak elleplezéséről, hogy a valóság többé nem valóságos. Minden hatalom és intézmény a lebeszélés stratégiájával beszél önmagáról.

A szimulákrum-elmélet tehát merőben új kontextusba helyezi a médiamanipuláció kapcsán felvetődő kérdéseket, igazság és hazugság viszonyát. Ha Baudrillard meglehetősen médiapesszimista forgatókönyvéböl indulunk ki, akkor gondolkodásunk és véleményünk szabad alakíthatósága nem csupán manipulációt szenved, de alapjaiban határoztatik meg.

\section{III.2.2. A vizuális média és az agresszív energiák relációi}

A médiamanipuláció kapcsán felmerülő problémakörök óhatatlanul elvezetnek a médiaagresszió jelenséghalmazához, hiszen a befolyásolás szélsőséges esetei véleménydiktatúraként is azonosíthatók. A média és az agresszió összefüggéseivel kapcsolatban az utóbbi 60 évben számos kutatás látott napvilágot, elsősorban médiapszichológiai vagy más, interdiszciplináris megközelítésben. Ma már lépten-nyomon találkozhatunk a két szó összekapcsolásával létrejött fogalommal, a médiaagresszió fogalmával, amelyet két teljesen eltérő jelenségre is használnak: egyrészt a média agresszióábrázolására, másrészt a média erőszakos megnyilvánulásaira, agresszorként való fellépésére értve. Mindkét témakörben a vizuális média termékei azok, amelyek a legerőteljesebb hatást kiváltják. A manipulációval és agresszióval kapcsolatos kutatások eddig nagyrészt a hagyományos, broadcasting-típusú, diskurzív tömegmédiára irányultak, az újmédia folyamatosan változó eszköztára még kevésbé feltérképezett. Utóbbi esetében azért is sokkal nehezebb megragadni a témát, mert a fogyasztók által feltöltött tartalmak mögött kevésbé lehet beazonosítani bármiféle egységes szándékot, müködési mechanizmusaiban sokkal több a kiszámíthatatlan elem. Az újmédia egyik sajátossága, a platformfüggetlenség (vagyis az a jelenség, hogy a tartalom elválik az infrastruktúrától) lehetetlenné teszi az olyan általános

\footnotetext{
391 U.o.
} 
megfogalmazásokat, amilyeneket a televízió vagy a rádió kapcsán még megtehettünk azok természetére vonatkozóan. Azt azonban biztosan állíthatjuk, hogy az újmédia világának beköszöntésével egyre nagyobb szerep hárul a vizualitásra és a képekre. A különféle csatornákra feltöltött videók és képek kapcsán tehát szintén releváns az agresszív energiák vizsgálata.

A média és az agresszió összefüggéseinek feltárásakor beleütközünk a képlékeny fogalmak problémájába. Hiába tekint vissza a diskurzus mintegy hat évtizedre, a médiaagresszió és a médiaerőszak fogalma még nem tisztult le kellőképp. A kettőt sokszor egymás szinonimájaként használják, holott - ahogy az agresszió és az erőszak fogalma közé sem lehet egyenlőségjelet tenni - úgy a médiaerőszak és a médiaagresszió fogalmát is érdemes megkülönböztetni.

Az erőszak fogalmát használhatjuk úgy, mint az erő megnyilvánulásának egy lehetséges módját. Olyan, előre eltervezett cselekményeket értünk alatta, amelyek másoknak szenvedést okoznak, illetve másokat fizikai erővel vagy hatalmi nyomással kényszerítenek valamire. Sokszor találkozunk azzal a felfogással, amely az erőszakot az agresszió direkt, közvetlen, okozati következménnyel, pl. sérüléssel, testi vagy lelki fájdalommal járó megnyilvánulásaként kezeli. Az agresszió fogalma mindenképpen összetettebb, komplexebb jelenséget jelöl, de ez sem definiálható könnyebben. Mibenlétéről a szakirodalom folyamatos vitáknak ad helyet, hiszen nem egy bizonyos típusú, könnyen meghatározható paraméterekkel és jól reprodukálhatóan leírandó viselkedéssel van dolgunk, sokkal inkább egy nagy változatosságot mutató gyüjtőfogalommal.

A természet- és társadalomtudományok különböző ágai természetesen más és más megközelítésben próbálják definiálni az agresszió fogalmát. A demográfiai változásokból, a túlnépesedésből, a források kimerüléséből és a globalizációból fakadó társadalmi problémák felerősödése az agresszió fogalmát előtérbe helyezte a filozófiai gondolkodásban is. Walter Brugger Filozófiai lexikonában olvasható meghatározás szerint ,az agresszió olyan viselkedést és ezt megalapozó érzelmi viszonyulást jelent, amelynek célja egy fenyegetőnek tartott tárgy elpusztítása, illetve valamely ellenállás leküzdése.” ${ }^{392}$ A szócikk jelzi, hogy bizonyos elméletek az agressziót ösztönkésztetésekre, mások frusztrációkra vezetik vissza, megint más nézetek szerint pedig velünk született és tanult mozzanatok alkotják az alapját. A filozófiai antropológia abból indul ki, hogy az emocionalitás nem determinálja kifejezetten a cselekvést, hanem a

\footnotetext{
${ }^{392}$ Walter Brugger: Filozófiai lexikon. Budapest, Szent István Társulat, 2005. 42.
} 
természet a fejlődés folyamán olyan kultúrává alakítható, amely az erkölcsi célkitüzések érdekében lehetővé teszi az agresszió korlátok közé szorítását és irányítását.

A fogalmak természetesen nem csak a magyar nyelvhasználatban képlékenyek, ugyanez az összemosódás megfigyelhető a nemzetközi szakirodalomban is a media violence illetve a media agression kifejezések kettősségében, noha a mindennapi társalgásban az előbbivel gyakrabban találkozhatunk.

A filozófia és a médiatudomány határterületén mozogva ez a fogalmi tisztázatlanság igencsak hátráltathatja a munkát. Tóth Péter etológus, médiakutató szerint a probléma talán feloldható, ha a definiálást egymástól elválasztva, az agresszió esetében természettudományi, míg az erőszak esetében szocio-kulturális keretben végezzük el, mindkét fogalmat újragondolva. ${ }^{393}$

A fogalmakkal kapcsolatos másik, igen nagy zavart okozó probléma az, hogy mind a médiaagresszió, mind a médiaerőszak fogalma alá (hiszen, ahogy arra korábban utaltam, ezeket sokszor szinonimaként használják) két teljesen különböző jelenséget is „,besöpörnek”. Az egyik jelenség a média erőszakábrázolása, vagyis az az eset, amikor a média bemutatja, közvetíti az agressziót. A másik, szintén igen szerteágazó kutatási témákat kínáló megnyilvánulás pedig az, amikor a média maga lép fel agresszorként, manipulálva az általa elérhető tömegek nézeteit és cselekedeteit.

Adott tehát két kifejezés és két különböző témakör, jelenség. Felmerülhet a gondolat, hogy az egyik kifejezéssel az egyik, a másikkal a másik jelenséget jelöljük, ám ha megpróbáljuk összekapcsolni a médiaerőszak fogalmát a médiában megjelenő erőszakkal, a médiaagresszió kifejezést pedig a média agresszorként való fellépésével szeretnénk azonosítani, gyorsan rájövünk, hogy ez korántsem ilyen egyértelmü. Hiszen a média nem csak az erőszakot, de az agressziót is megjeleníti, illetve fogyasztóival szemben nem csak agressziót, de erőszakot is kifejt. A továbbiakban - elkerülendő, hogy minden alkalommal mindkét fogalmat fel kelljen felsorakoztatni - a médiaagresszió kifejezést fogom használni, az agresszió fogalmának az erőszak fogalmához képesti komplexebb volta miatt.

A médiaagressziót tehát kétféle értelmezésben kell vizsgálnunk. Az egyik értelmezés szerint médiaagressziónak nevezzük a médiában megjelenő agressziót. A másik értelmezés pedig a média agresszorként való fellépésére vonatkozik, mikor nem a benne megjelenő tartalmak váltják ki a manipulatív hatást, hanem maguk a médiamechanizmusok agresszívek.

393 Tóth Péter: A médiahatás-kutatás problémái: az agresszió és az erőszak rekonceptualizálása. In: Médiakutató, 2007. tél. 
A médiában megjelenő agresszió jelenségével kapcsolatban mintegy hat évtizedes múltra tekintenek vissza a különféle megközelítéseket alkalmazó kutatások. Folyamatosan készülnek felmérések, statisztikák, kimutatások. A média erőszakos megnyilvánulásai gyakori témái a hétköznapi társalgásnak is, legtöbbször szörnyülködés formájában. Még ha a tendenciák feletti sopánkodás többnyire álszent is - hiszen akik legjobban kárhoztatják a médiát, azok is többnyire aktív fogyasztói - indokolatlannak semmiképp nem mondható. Az Egyesült Államokban már az '60-as évektől megdöbbentő adatok láttak napvilágot. Egy 1968-as kutatás becslése szerint például egy amerikai fiatal 15 és 25 éves kora között átlagosan 13400 ember erőszakos halálát nézi végig a képernyőn. ${ }^{394}$ Egy 1977-es vizsgálat szerint Sao Paoloban egy hétköznap estén, hét csatornán 3 óra leforgása alatt 64 gyilkosságot, 38 lövöldözést, 7 nemi erőszakot, 22 verekedést, 3 rablást és 23 megfélemlítést, zsarolást mutattak be. ${ }^{395}$ A különböző évekből és országokból származó statisztikai adatokat hosszan lehetne sorolni. Mindezekkel a különféle mozgóképes anyagokban találkoztak az érintettek, de már a statikus fotó is alkalmas felület az agresszió közvetítésére.

Susan Sontag úgy fogalmazott, hogy a fénykép ártatlanabb, tehát precízebb viszonyban van a látható valósággal, mint az utánzás más eszközei. Ám mielőtt komolyan vennénk az ártatlanságra vonatkozó megjegyzését, kicsivel később hozzáfüzi: „A fényképezőgép használata burkoltan mindig magában hordozza az agressziót." ${ }^{\circledR 96}$ Hiszen a fényképezés a vadászat, a becserkészés aktusára is emlékeztet, aki elkattintja, birtokba veszi áldozatát ${ }^{397}$. Sontag szerint a fotográfiai rögzítés agresszivitása azonban mindenekelőtt a fényképek mindenütt-jelenvalóságában rejlik. „Az eszményítő kép (a legtöbb divat- és állatfotó) semmivel se kevésbé agresszív, mint az olyan mü, amely a dísztelenségből kovácsol erényt (mint az osztályfénykép, a sivár csendélet, a rendőrségi nyilvántartó kép.)”398 - írja. Mégis, amikor a médiában megjelenő agresszióról esik szó, a legtöbben a vizuális médián belül a mozgóképes anyagokra gondolnak, hiszen ezek közvetítik ma a legtöbb, és legkönnyebben dekódolható erőszakos mozzanatot. Mind a valóságot bemutató hírmüsorokban, mind a fikció területén mozgó alkotásokban megjelenő agresszió része a mindennapjainknak. Utóbbiakat illetően már nem csak a horrorfilmek, thrillerek, krimik, háborús filmek vannak tele brutalitással és vérrel,

\footnotetext{
394 A National Association for Better Radio and Television adatait Marcel Frydman közli 1993-ban megjelent Télévision et violence címü könyvében. Frydman, Marcel: Televizió és agresszió. Budapest, Pont kiadó, 2004. 8.

${ }^{395}$ Ranschburg Jenő: Agresszivitás a képernyőn. In: Szávai Ilona (szerk.): Tévé elött - védtelenül? Tanulmányok a média hatásáról. Budapest, Pont Kiadó, 2010. 11.

396 Sontag, Susan: A fényképezésröl. Európa Kiadó, 1981. 12-13.

${ }^{397}$ Erre utal Flusser is a fényképezés gesztusa kapcsán, hozzátéve, hogy ,a fényképész az ő vadját nem a nyílt mezőn, hanem a kulturális objektumok sürüjében űzi, és vadászösvényeit ez a mesterséges tajga alakítja." Lásd: Flusser, Vilém: A fotográfia filozófiája. Tartóshullám - Belvedere - ELTE BTK, Budapest, 1990. 28.

${ }^{398}$ Sontag, Susan: A fényképezésröl. Európa Kiadó, 1981. 13.
} 
de az akciófilmek, drámák, sőt, a romantikus filmek sem mellőzik teljesen az ilyen jeleneteket. Ahogy fejlődik a filmes technika, egyre könnyebb az erőszak naturális képi ábrázolása: a számítógépes animáció révén nem okoz problémát például a lőtt vagy szúrt sebek, levágott végtagok élethű megjelenítése.

Sokáig a televízió volt a médiaerőszak ellen kampányolók legfőbb céltáblája. A közismertté vált brit aktivista, Mary Whitehouse 1964-ben publikált, a televízió „kisöpréséről” szóló pamfletjében például arról értekezett, hogy a tévé a vallás nélküli modern társadalomban egyre terjedő erőszakot tárja a néző elé, így maga is hozzájárul a nyugati keresztény értékrend destabilizálásához, sőt pusztulásához. ${ }^{399}$ Napjainkban, amikor a hagyományos televíziózás kezd egyre inkább háttérbe szorulni, a videómegosztó csatornák, a mozgóképes anyagokat is közzétevő közösségi oldalak és a számítógépes játékok kapják a legtöbb kritikát.

A (vizuális) média erőszak- és agresszió-ábrázolásának megítélését illetően különböző nézőpontok léteznek. Vannak, akik évtizedek óta a vészharangot kongatják, és vannak olyanok is, akik szerint nincs akkora baj, hiszen az erőszak az élet része, természetes velejárója, és hiteltelen lenne a média, ha soha nem mutatná. Az egyik elmélet szerint - melyet föleg a gyerekekre és a fiatalokra vonatkoztatnak - az eröszakos tartalmú képsorok felzaklatják a befogadót, akiben hatásukra agresszív energiák gyülnek fel, amelyek utat találhatnak a környezetük felé. Albert Bandura már az 1960-as évek elején kísérletekkel bizonyította, hogy az agresszív modellek megfigyelése - akár élőben, akár a tévé képernyőjén - jelentős mértékben fokozza a gyermekek agresszív késztetéseit. ${ }^{400}$ Később, már kifejezetten a televízióban megjelenő agressziót vizsgálva hasonló következtetésekre jutott Marcel Frydman is, hangsúlyozva az agresszív képsorok feldolgozásához, értelmezéséhez nyújtott (pedagógusi és szülői) segítség fontosságát. ${ }^{401}$ Noha Frydman 1993-ban megfogalmazott egy konkrét pedagógiai programot, a kiskorúak azóta sem kapnak elegendő támogatást a médiaértéshez és a kritikus médiafogyasztói attitüd kialakulásához. Az újmédia interaktív, a felhasználót közvetlenül, személyesen megszólító és bevonó közege miatt ez nehezebb is, mint a televízió egyeduralma idején. Az interneten már nem csupán belefutnak az agresszív tartalmakba, de kutathatnak is utánuk, illetve közösségükben terjeszthetik azokat.

\footnotetext{
399 Whitehouse, Mary: Cleaning-up TV: From Protest to Participation. Blandford, 1967.

${ }^{400}$ Bandura, A. \& Ross, D. \& Ross, Sh. A. ([1963] 1981) Film által közvetített agresszív modellek utánzása. In: Csepeli György (szerk.) Csoportlélektan. Budapest, Gondolat, 515-525.

${ }^{401}$ Frydman, Marcel: Télévision et violence. Les Éditions Médicales et Paramédicales de Charleroi, Belgique, 1993.
} 
A Facebook, a Cornell Egyetem és a Kaliforniai Egyetem munkatársai által 2012-ben elvégzett kutatás $^{402}$ is egybecseng Bandura és Frydman megfigyeléseivel: az egyik csoport tagjainak a közösségi oldalon az ismerőseik által közzétett megosztások közül elsősorban a negatív tartalmakat mutatták, míg a másik csoport tagjai inkább pozitív tartalmú megosztásokat láttak. A megfigyelések azt igazolják, hogy aki több szomorú és haragos tartalmat látott, az maga is inkább ilyeneket posztolt. (A kutatást egyébként botrány övezte, mert a több százezer, érzelmi befolyásnak kitett felhasználó nem tudott arról, hogy kísérleti alany. A készítők azzal érveltek, hogy a regisztrációkor elfogadott felhasználási szabályzattal hozzájárultak, hogy az üzenőfaluk tartalmát tudatosan válogassák össze. ${ }^{403}$ Így nem csupán arra szolgáltattak példát, hogy a közösségi média miképp tud agressziót gerjeszteni, de arra is, hogyan léphet fel agresszorként.)

A témával kapcsolatos diskurzus általában két fontos kérdést szokott körbejárni. Az egyik kérdés, hogy attól nő-e az erőszakos cselekmények száma, hogy ilyen viselkedésformákat látunk a médiafelületeken, vagy azért van a képernyőn ilyen sok erőszak, mert ilyen a világ, ezt érzik a nézők hitelesnek és érdekesnek? A másik, szintén nehezen megválaszolható kérdés pedig az, hogy lehet-e a médiának erőszak-levezető hatása?

George Gebner, a téma egyik vezető kutatója nem azt tartotta a médiaerőszak legnagyobb veszélyének, hogy közvetlen módon erőszakot vált ki a befogadóból, hanem azt, hogy átalakítja, torzítja a világról alkotott elképzelését. ${ }^{404}$ Megkülönböztette a régi, például a népmesékben tetten érhető, szelektíven alkalmazott és dramaturgia által motivált agressziót a kereskedelmi céllal előállított, öncélú, ok-okozati összefüggésektől mentes ún. vidám eröszaktól, amely happy enddel végzödik. Elöbbi természetes része volt a mitológiáknak, a különféle népek mondavilágának - s mivel a médiát napjaink mitológiájának inkubátoraként, illetve a szocializáció terepeként is felfoghatjuk, a megmagyarázott, következményekkel járó agresszió bemutatása (ahol az agresszor elnyeri méltó büntetését) társadalmi szempontból akár itt is hasznos lehetne.

Van olyan vélekedés, mely szerint ha agresszív tartalmakkal teli filmeket nézünk, vagy olyan számítógépes játékot játszunk, amelyben le kell lőni, meg kell semmisíteni az ellenséget, azzal kiéljük agresszív hajlamainkat, és nem közvetítjük azokat hús-vér embertársaink felé. Az

\footnotetext{
${ }^{402}$ Adam D. I. Kramer, Jamie E. Guillory and Jeffrey T. Hancock: Experimental evidence of massive-scale emotional contagion through social networks. Proceedings of the National Academy of Sciences, 2014. http://www.pnas.org/content/111/24/8788

403 A sajtóban is nagy visszhangot keltett botrány részleteit lásd a HVG cikkében: http://hvg.hu/tudomany/20140630_kiderult_titokban_manipulalt_minket_a_fb (letöltés: 2018.03.11.)

${ }^{404}$ Gebner, George: A média rejtett üzenete. Budapest, Osiris Kiadó \& MTA-ELTE Kommunikációelméleti Kutatócsoport, 2000.
} 
ún. katarzis-elmélet hívei szerint az erőszak szemlélése az agresszív késztetések alóli felszabaduláshoz vezet, szemben az ópiumelmélet hipotézisével, mely abban áll, hogy a médiában látott erőszak eltompítja az érzékeket, a befogadó érzéketlenné válik az agresszió megnyilvánulásaival szemben, így közönyössé válik a környezetében tapasztalható erőszakos cselekmények iránt is. ${ }^{405}$ Ám létezik egy olyan megközelítés is, melynek értelmében nem feltétlenül azért köti le a figyelmünket a médiában ábrázolt erőszak, mert valóban agresszívek volnánk, hanem azért, mert érzékenyek vagyunk a témára. Önkéntelenül is kutatjuk az agresszió mögött meghúzódó motivációkat, a társadalmi-közösségi felelősséget, latolgatjuk az agresszió lehetséges hatásait.

Stachó László és Molnár Bálint 2003-ban egy hiánypótló tanulmányban összegezték a média és az agresszió kapcsolatának kutatására jellemző elméleti és empirikus irányokat, átfogóan bemutatták a témában zajló tudományos vitát. Arra jutottak, hogy ,az agresszió és a média kapcsolatának tudományos tanulmányozásában ma is nagy szükség van a kutatások részletes és őszinte, nem dogmavezérelt bírálatára, s az elméletek, valamint az empíria hiányosságainak őszinte, nem a támadás vagy a vita elsődleges céljával történő kiemelésére."406 A tanulmány jól mutatja, hogy a jelenség kutatása igen népszerü, sokakat foglalkoztat, és az érdeklődés a jövőben várhatóan csak fokozódni fog.

A médiaagresszió fogalmának másik megközelítése - médiaagresszió mint média által kifejtett agresszió - a fentinél lényegesen összetettebb és nehezebben megragadható. Ennek a megközelítésnek a kiindulópontja az, hogy a média akkor is felléphet agresszorként, ha éppen nem erőszakos tartalmakat közvetít, nem agressziót ábrázoló képsorokat vetít elénk. Az agresszió mindig valamilyen ellenállást igyekszik legyőzni, és ebben hatalmas eszköztár áll a rendelkezésére a fizikai erőszak legbrutálisabb megnyilvánulásaitól a finomabb kényszerítő eszközökig. A legkifinomultabb eszköz a manipulációnak az a formája, amikor az agresszió elszenvedője nincs is tudatában annak, hogy manipuláció áldozata - a médiamanipulációra leginkább ez jellemző. Sőt, az olyan eset sem ritka, hogy a fogyasztó tudatában van ennek, de mivel ez az állapot rövidtávon szórakoztatja, leköti öt, a hosszútávú következményekre nem gondolva zokszó nélkül kész „elszenvedni” azt.

Ha a médiaagressziónak erről a formájáról beszélünk, akkor agresszió alatt természetesen nem az egyén sérelem- vagy kár okozására irányuló cselekedeteit értjük, melyek ösztönkésztetésekre vagy frusztrációkra vezethetők vissza. A tömegmédia esetében egyfajta csoportos agresszióról van szó, amely inkább a jogi értelemben vett, militarista agresszióra

\footnotetext{
${ }^{405}$ Film- és médiafogalmak kisszótára. Budapest, Korona Kiadó, 2002. 264.

${ }^{406}$ Stachó László - Molnár Bálint: Médiaerőszak: tények és mitoszok. In: Médiakutató, 2003. tél.
} 
emlékeztet, melynek célja egy közösség vagy terület szuverenitásának, függetlenségének letörése az agresszorként fellépö hatalom törekvéseinek megfelelöen. Jelen esetben egyértelműen a közvélemény uralása, irányítása alá vétele jelenti a célt.

Felvetődik persze a kérdés, hogy a média maga az agresszor, vagy az újságok, televíziók, rádiók, internetes portálok csupán „hadtestek”? Ha valamiféle modern hadviselésről van szó, akkor ki irányítja a csapatokat? Erre nehéz választ adni anélkül, hogy összeesküvéselméletekbe csúsznánk bele. Tanulságosak viszont Ben Haig Bagdikian fejtegetései, aki The Media Monopoly ${ }^{407}$ című könyvében lerántja a leplet az amerikai médiamonopóliumok praktikáiról és taktikáiról: a fúziók révén egyre több és több médiacég kerül egyre kevesebbek kezébe. Az amerikai-örmény médiaszakember bemutatja, hogy a kereskedelmi médiát milyen behatások érik: milyen célok, érdekek és egyéb tényezők határozzák meg a müködését. A modern médiabirodalmak élén álló személyeknek tehát minden bizonnyal hatalmukban áll bizonyos mértékig megszabni a média agresszív megnyilvánulásainak irányait. (Ugyanakkor látható, hogy a gépezet mára nagy mértékig önjáróvá vált. A közösségi internetmédia korában már nem csak hivatásos szakemberek készítik a médiatartalmakat, bárki bármit feltölthet az internetre. Ennek ellenére úgy tünik, e szabadság csak odáig terjed, míg a fogyasztói társadalom célkitüzéseivel összehangolható. A kétezres évek második évtizede azonban hangos az olyan botrányoktól, melyek középpontjában a közösségi oldalak információáramlásának befolyásoltsága áll.)

Az előzőekben szólhatunk a médiában megjelenő agresszióról és a médiáról mint agresszorról. De meg kell jegyezni, hogy egyre inkább elötérbe kerül egy harmadik problémakör is: az az eset, amikor a média az agresszió eszköze. Nem csupán az agresszió ábrázolójaként, mint az első esetben, és nem is egy központi mechanizmusként mint a második esetben. Az újmédia lehetővé teszi, hogy a média valóban fegyverré váljon és konkrét, kiválasztott egyénekre irányuljon. Gondoljunk csak az internetes zaklatásokra vagy zsarolásokra, melyek között élen járnak a képekkel való visszaélések. Mivel - ahogy korábban láttuk - a privátképeket övezö intimitás eltünik, sokan bánnak óvatlanul önmaguk képi reprezentációjával, és ezt nem nehéz kihasználni. Ha egyszer megszületik egy digitális kép hiába gondoljuk, hogy csak két emberre (pl. meztelen fotók) vagy egy baráti társaságra (pl. ittas állapotban készült fotók) tartoznak - semmi nem garantálja többé, hogy nem válik a kép szereplője ellen irányuló fegyverré, és egyúttal az egyén életútját dokumentáló vizuális portfólió (nemkívánatos, de gyakorlatilag kitörtölhetetlen) részévé.

\footnotetext{
${ }^{407}$ Bagdikian, Ben H.: The Media Monopoly. Boston, Beacon Press, 1983.
} 


\title{
III.3. Az újmédia közegében realizálódó vizuális portfóliók hatásmechanizmusai
}

\author{
„Senki sem tudja, mi bukkan majd felszínre a globális kultúra \\ laboratóriumából - és éppen ez teszi a kort olyan izgalmassá." "408
}

Lev Manovich

\section{III.3.1. Képkultúra az újmédia felületein}

Az újmédia felületein napvilágot látó képek digitálisak, testetlenek, tiszta információ formájában léteznek. A különbözö digitális képek közül a digitális fotók azok, amelyek legnagyobb számban és legmeghatározóbb módon vannak jelen korunk vizuális kultúrájában. Mint láttuk, a digitális fotók a kémiai eljárás során létrejövő fotóktól természetükben alapvetően különböznek, hiszen egyfajta lezárhatatlanság, befejezhetetlenség jellemzö rájuk. Ennek az átalakulásnak minden bizonnyal nagy szerepe van abban, hogy az 1839-ben bemutatott találmány mindeddig nem veszített vonzerejéből. Lev Manovich szerint „a fénykép szívósságának oka rugalmasságában rejlik, hiszen könnyen vegyíthető más vizuális formákkal: rajzokkal, 2D-s és 3D-s dizájntechnikákkal, vonaldiagramokkal, stb." ${ }^{409}$ Manovich arra is felhívja a figyelmet, hogy a mai fényképek nagy része már nem „tiszta” kép, hanem valamiféle hibrid. Vegyítjük őket különféle dizájnelemekkel, manipuláljuk őket annak érdekében, hogy stílusosabb megjelenést, teltebb színeket, határozottabb grafikai megjelenést nyújtsanak. Úgy véli, „fényképkultúrában” élünk, azonban meg kell tanulnunk a fotográfia szó új jelentését. Hiszen a fotográfia „ma már ténylegesen foto-GRÁFIA, hiszen a fotográfia csupán alapanyag a grafikai ötvözet számára. (...) Ez a folyamat a természetben, a társadalomban és a kultúrában egyaránt változásokat implikál." ${ }^{\text {410 }}$

A hibrid kép a manipuláció végtelen lehetőségei előtt nyit ajtót. Megfelelő kezekben természetesen lehet a vizuális kultúra egy olyan eleme, amely határtalan kreativitásra ad alkalmat, és a vizuális müvészet számára is kiváló terep. A hibrid képek megalkotásának lehetősége azonban nem csak a kifinomult látásmóddal és ízlésvilággal rendelkező kevesek kiváltsága, hanem bárki számára fennáll: szoftverek sokasága kínál ehhez effekteket, funkciókat, variálható sablonokat.

\footnotetext{
${ }^{408}$ Manovich, Lev: Flash generáció. In: Gerencsér Péter (szerk.): Új, média, müvészet. SzatírIKON könyvek, Universitas Szeged Kiadó, Szeged, 2008.

${ }^{409}$ Manovich, Lev: Jövö-kép. In: Gerencsér Péter (szerk.): Új, média, müvészet. SzatírIKON könyvek, Universitas Szeged Kiadó, 2008. 92.

${ }^{410}$ U.o.
} 
Az, hogy ebben mekkora veszély rejlik, attól is függ, hogy a technika változásával lépést tart-e a képekhez való hozzáállás. Amennyiben a szerkesztett fotókat és a hibrid képeket is objektív repreneztációkként kezeljük, a valóságra nyíló ablakként fogjuk fel, akkor bizonyára jogosak az aggodalmak. Ám úgy tünik, az attitüdök is változóban vannak, még ha nem is feltétlenül a technikai változásokkal szinkronban.

Manovich egy 2002-es tanulmányában flash generációnak ${ }^{411}$ nevezi az alkotóknak azon csoportját, akik a '90-es évek vége óta hódító Adobe Flash, vagy valamely hasonló, webes alkalmazások, játékok, rövidfilmek és mobil tartalmak fejlesztésére alkalmas programmal dolgoznak. „Ez a generáció már nem törődik azzal, hogy alkotásaikat művészetnek vagy designnak hívják-e. (...) Ez a generáció saját kulturális rendszereinek megteremtése érdekében saját szoftverkódokat ír, ahelyett, hogy a kereskedelmi média mintáit használná. Az eredmény az adatvizualizációk, a vektorhálók, a pixelrácsok és a nyilak újfajta modernizmusa: Bauhausdesign az információsdesign szolgálatában" - írja, hozzátéve, hogy az információsdesignt eszközként használja a valóság megértéséhez, míg a programozás a hatalommegosztás (empowerment) eszközévé válik. ${ }^{412}$ Manovich szerint a flash esztétika szembe megy a kereskedelmi média grafikai áradatával és a korábbi médiaművészettel, és jóval könnyedebb, visszafogottabb, minimalistább. ${ }^{413}$ A Manovich által 2002-ben jelzett törekvés azonban az azóta eltelt időben nem mutatta igazán meggyőzően a térhódítás jeleit.

Említettük az összemosódást. Mi következik abból, ha a képi információt kifinomult látásmód és szakmai tudás nélküli amatőrök adják át? A verbalitás szintjén eltünik a tény és a vélemény, a hír és a publicisztika közötti különbség. Ugyanez a tendencia megfigyelhető a képek esetében is: az objektív, tényszerü sajtófotók és a szerkesztett fotók közötti különbségtétel igénye látszik elveszni.

\section{III.3.2. A szabadság lehetőségei a képekhez kötöttség korában}

A szabadság fogalmának definiálása a filozófia legnagyobb és legrégebbi problémái közé tartozik - ezért a szabadság látásra és képekre való vonatkoztatása csupán egy gondolatkísérlet erejéig kap helyet jelen munkában azon indíttatásból, hogy a manipuláció témaköre megkívánja a manipuláció-mentesség témakörébe való becsatlakozást. Egyre nyilvánvalóbbá válik ugyanis,

\footnotetext{
${ }^{411}$ Manovich hangsúlyozza, hogy a flash generáció és a flash esztétika fogalmát nem kapcsolja konkrétan az ilyen nevet viselő szoftver-formátum használatához, hiszen ez a generáció és ez az esztétika már elhagyja a flasholdalakat. Inkább e generáció jellemzői, az általuk behozott új szemlélet állt vizsgálódása középpontjában.

${ }^{412}$ Manovich, Lev: Flash generáció. In: Gerencsér Péter (szerk.): Új, média, müvészet. SzatírIKON könyvek, Universitas Szeged Kiadó, Szeged, 2008. 145.

${ }^{413}$ U.o. $157-158$
} 
hogy nagy erőfeszítésbe kerül kivonni magunkat a nemkívánatos képek hatásai, és a képek nemkívánatos hatásai alól. Mindez szükségszerüen elvezet a szabadság kérdésköréhez, hiszen saját gondolataink és döntéseink uralását érezhetjük veszélybe kerülni.

Noha az egyes országok különböző médiatörvényei valamelyest határokat szabnak például a reklámok térnyerésének, a reklámtartalmú képek elhelyezésének, a szabályozás és korlátozás lehetőségének nem csupán a fogyasztásra buzdítás etikája kapcsán kellene felmerülnie. Talán attól sem vagyunk már messze, hogy körvonalazódjék az igény a látás zavartalanságának kollektív biztosítására - hiszen egyre nyilvánvalóbb, hogy a látás szabadsága is lehet ugyanolyan fontos, mindenkit születésétől fogva megillető jog, mint a szólás-, a vallás- vagy lelkiismereti szabadság, vagy esetleg a „felejtéshez való jog”, amely az utóbbi időben egyre többször felmerül az internetes tartalmak eltávolításának igényelhetősége kapcsán.

Anélkül, hogy a szabadság fogalmi lényegének részletes kibontására vállalkozánk, kiindulópontként címszavakban elmondhatjuk, hogy filozófiai értelemben beszélhetünk fizikai, személyes, erkölcsi szabadságról, gondolati szabadságról, megkülönböztethetünk külső és belső, valódi és látszólagos, pozitív és negatív szabadságot. Fizikai értelemben szabad az, aki megtehet valamit, s ezt a lehetőséget erőszak vagy erőhatalom nem akadályozza. A személyes szabadság a test szabad mozgásában, használatában áll, fizikai erő(szak) által korlátozható. Ilyen értelemben a szabadság velünk született állapot, melynek hiányában rabok vagyunk. A szabadság fogalmának ellentéte ebben az esetben egyértelműen a rabság. Erkölcsi szabadságról, gondolatszabadságról azonban érdemben akkor beszélhetünk, ha a szabadságot az emberi akarat eredményének, vívmányának tekintjük, nem pedig az emberrel született állapotnak. Rudolf Steiner megközelítése szerint itt, a földön kénytelenek vagyunk ugyan elszenvedni a test kényszerítő befolyásait, ám a megismerés, a gondolkodás területén elérhetjük, legalábbis megközelíthetjük a szabadság állapotát. Steiner A szabadság filozófiája című mủvében megfogalmazott egy olyan kitételt is, amely szerint szabad az ember, ha mindenkor önmaga szerint képes élni. ${ }^{414}$ Ha ezt az értelmezést tekintjük, akkor a szabadság fogalmának ellentéte nem egyértelműen a rabság, inkább a befolyásoltság alatt állás, a cselekedeteink szándékaink szerinti irányítására való képtelenség. Kellö önuralom és egyéb erények birtokában a rabságban tartott ember is megteremtheti azt a belső, mentális állapotot, amelyben önmaga szerint képes élni. Ám a látszólag szabad ember ilyen típusú szabadságának megvalósítását is gátolhatják, akadályozhatják olyan külső körülmények, amelyek kifejezetten

\footnotetext{
${ }^{414}$ Steiner, Rudolf: A szabadság filozófiája. Budapest, Genius Kiadó - Új Mani-fest Kiadó, 2005.
} 
a gondolkodásunk megzavarására, nézeteink és döntéseink manipulálására irányulnak. Így olyan helyzet is előállhat, amikor testünk szabad, elménk, akaratunk azonban befolyás, manipuláció alatt áll.

Amennyiben az a kérdésünk, miben áll a látás szabadsága, két irányból közelíthetünk a megfejtéshez. Amennyiben a szabadság fogalmát az egyénre vonatkoztatjuk, és fizikai szempontból közelítjük, akkor a látás szabadsága kétféle állapotot jelölhet. Az egyik csupán annyit jelent, nem fogja be senki a szemünket, illetve nem tesz minket semmilyen külső, fizikai erő orvosi értelemben vakká. A másik állapot - amely jelen esetben érdekes - abban manifesztálódik, hogy nem zavarja meg, nem manipulálja senki és semmi a szemünk elé táruló látványt, nem ködösíti vagy torzítja el azt. Az ilyen manipulációs illetve zavaró tényezők közé sorolható a túl sok, egymást kioltó vizuális impulzus, az ingerlő, figyelmet magához vonzó dolgok feltűnése a látómezőnkben, amelyek kisebbítik, kioltják az egyéb ott lévő dolgok iránti, egyébként meglévő érdeklődést. A látás szabadsága ezen első esetet tekintve tehát nem más, mint a korlátozások és zavaró tényezők kiiktatása a szem, mint érzékszerv használatának folyamatából.

A kérdéshez azonban egy másik irányból is közelíthetünk. Helyezzük át a hangsúlyt a szemről az elmére, az információk befogadásáról a (látás útján nyert) információk feldolgozására. Ha zavart, torzított, manipulált információkat fogad be a szemünk, azokat az agyunk neuronálisan érzékeli ugyan, ám az elménk nem tudja megfelelő módon feldolgozni. A látottakból nem tudunk építkezni, nem tudjuk az információkat rendszerbe foglalni. Márpedig a felületes, a torz illetve a nem szintetizált információk nem segítik, de inkább hátráltathatják döntéseink megszületését. Ily módon akadályoznak bennünket a gondolati és akarati szabadság óhajtott állapotának megteremtésében. Ebben az értelemben a látás szabadságát tehát úgy definiálhatjuk, mint a szemünk elé táruló látvány feldolgozási, értelmezési folyamatának szabadságát, amely szoros összefüggésben áll döntési és ítélkezési folyamatainkkal.

Az emberi szervezetnek a regenerálódáshoz szüksége van arra, hogy időről időre kiiktassa az őt érő ingereket. Régóta ismert kínzási módszer az, amikor valakit különféle, állandó ingereknek tesznek ki, melyek következtében az illető képtelen pihenni, elméje összezavarodik, személyisége megtörik (illetve egy idő után létfontosságú szervei is leállhatnak). A mindennapokban ilyen drasztikus behatásokkal ugyan nem találkozunk, de tény, hogy egyre kevésbé tudjuk kivonni magunkat a plakátok, hirdetések, reklámfeliratok hatása alól.

Korábban már esett szó látás és gondolkodás, látás és szubjektum kapcsolatáról. Mindannyian rendelkezünk egy személyes vizuális tudattal, és ennek értelmében dolgozzuk fel 
az optikai jelcsoportokat, amelyek látómezőnkön átmenőben időlegesen rögzülnek, azaz amelyeket éppen meglátunk. Ezekből maradványként a legjellemzőbb viszonyok megerősödnek, és folyamatosan építik képzeteinket. ${ }^{415}$ Különösen a nagyvárosban élő emberre igaz, hogy az utcán járva-kelve folyamatosan kerülnek be különböző képi tartalmak a látómezejébe, majd kerülnek ki onnan anélkül, hogy látványuk tudatosulna. Tudat alatt, maradványként azonban hatnak, hiszen megjegyezzük a márkaneveket, elfogadjuk ideálisnak az általuk közvetített világképet és emberképet - annak ellenére, hogy sokszor ráébredünk, mennyire zavar és idegesít bennünket a dömping. Befolyásolják igényeinket, vágyainkat, döntéseinket. (A befolyásolás mint cél, természetesen minden korban igaz volt a reklámokra, ám a mennyiség ilyen elképzelhetetlen nagyságrendje már korunk specifikus jellemzője.) Erőteljesen hatnak egyéni, saját szemléleti módunk ${ }^{416}$ kialakítására, és figyelembe véve, hogy e szemléleti mód meghatározza a későbbi látványértelmezéseinket is, hosszútávú befolyással is bírnak.

A fogyasztói társadalom és a tömegmédia sajátos müködési mechanizmusaiból fakad azonban, hogy a különböző manipulációs törekvések észrevétlenek maradnak, illetve a társadalmi jólét elfedi a belőlük fakadó hátrányokat. A látás szabadságának megvalósíthatósága kapcsán éppen ezért felvetődhet a kérdés, az emberek többsége vajon rabságnak érzi-e egyáltalán jelen állapotát, és mennyire vehetők rá arra, hogy tenni akarjanak látásszabadságuk érdekében? Jean-Jacques Rousseau A társadalmi szerzödés címü mủvében azt állítja, hogy ha az állampolgár, mint a társadalom tagja nem ébred rá szabadsága adta lehetőségére, akkor kényszeríteni kell őt a szabadságra, hiszen enélkül az állampolgári kötelezettségek is értelmetlenek, zsarnokiak. ${ }^{417}$ Vajon vonatkoztatható ez a tisztánlátásra?

Ahhoz, hogy valaki szabaddá legyen (abban az értelemben, hogy szabaddá tegye önmagát), először is be kell látnia, hogy nem az. Ahhoz, hogy az egyes ember látásának szabadsága megvalósulhasson, mindenekelőtt tudatosulnia kell az illetőben annak, hogy látása révén gondolatai befolyás alatt állhatnak. A szabadság mint állapot elérésének szintén fontos előfeltétele, hogy az illető törekedjen az állapot elérésére, akarjon szabad lenni. Amennyiben a látás szabadságát úgy definiáljuk, mint a szemünk elé táruló látvány feldolgozási, értelmezési, megismerési folyamatának szabadságát, amely szoros összefüggésben áll döntési és ítélkezési

\footnotetext{
415 Bálványos Huba - Sánta László: A vizuális megismerés és a vizuális kommunikáció. Budapesti Tanítóképző Főiskola, 1996. 98.

${ }^{416}$ Bálványos Huba és Sánta László úgy véli, mivel a látványt mindig önmagunk értelmezzük, mindig benne van a tárgyi tévedés, félreértés lehetősége is - ez a szemlélet jellemzője, a szemléleti elfogultság pedig az előítéletek forrása. Ld.: A vizuális megismerés és a vizuális kommunikáció. Budapesti Tanítóképző Főiskola, 1996. 98.

417 Rousseau, Jean-Jacques: A társadalmi szerződés. (Ford.: Radványi Zsigmond) Phönix-Oravetz Kiadás, Budapest, 1947. 32.
} 
folyamatainkkal, akkor ezt az állapotot külső kényszerítő erő aligha teremtheti meg. Belső autonómiát csak önmagunkban hozhatunk létre, gondolataink szabadságát csak magunknak teremthetjük meg. Saját döntésünkön múlik, akarjuk-e a tisztánlátást.

Ha azonban a látás szabadságát úgy értelmezzük, mint a korlátozások és zavaró tényezők kiiktatását az érzékszervként igénybe vett szem használatának folyamatából azzal a céllal, hogy biztosítsuk megismerési és gondolatalkotási folyamataink szabadságát, akkor már más a helyzet. Ebben a szituációban a szabadságra nem vágyó egyén is közelebb juttatható a szabadság állapotához, hiszen a szabadság kényszerítése ilyen értelemben csak az alanyra ható külső, zavaró tényezők felfüggesztését jelenti. Ilyen esetben a „szabaddá tevés” egyszeri, gyakorlati aktus, például egy törvény vagy rendelet megalkotása, amely korlátozza az állampolgárokat érő, kéretlen vizuális impulzusokat. Ennek megvalósíthatósága ugyan számos problémát felvet, az elv megfontolása azonban egyre aktuálisabbá válik. Nem csupán a szemléletmódunkra gyakorolt agresszív presszió, gondolkodásunk zavartalanságának biztosítása miatt, de annak érdekében is - bár a felvetés talán anakronisztikus és naiv, de egy gondolatkísérletet talán megér - hogy a kép visszanyerjen valamit korábbi értékéböl, és ismét részünk lehessen abban az élvezetben, amit a fizikai kép szemlélése nyújtott a képdömping időszaka előtt.

Annyi bizonyos, hogy napjaink embere nem tud elbújni a fizikai képek mindenütt jelenvalóságából fakadó vizuális impulzus-zápor elől, mert a menekülés együtt járna a társadalomból való kiszakadással, egyfajta remeteélet vállalásával. Aki azonban marad ebben a közegben, az egyre kiszolgáltatottabbá válik, hiszen semmiféle védelmet nem remélhet a számára nemkívánatos, az öt zavaró vizuális impulzusok ellenében. A megoldás csupán az lehet, ha a jelenség társadalmi problémaként tudatosul, és megindul egy párbeszéd arról, hogyan lehetne a véleményszabadság minél csekélyebb csorbítása mellett egyfajta kollektív látásszabadságot is megvalósítani, amely biztosítja az egyes ember és a közösség számára egyaránt, hogy uralja gondolatainak és döntéseinek szabadságát.

Ezt illetően talán számolhatunk azzal a lehetőséggel is, hogy az ember - értelme segítségével - képes lehet felülemelkedni egy adott helyzeten, képes lehet arra, hogy más környezetben éljen, sőt arra is, hogy mesterséges módon egy olyan környezetet alakítson ki, amely a kívánatos életlehetőséget biztosítja számára. Úgy is mondhatjuk, hogy az ember a teljességre való irányultsága miatt felszabadulhat a környezet kényszere alól, illetve folyamatosan felszabadíthatja önmagát. Ernst Cassier hasonlóan fogalmaz a kultúra egészére vonatkoztatva: „Az emberi kultúra egésze leírható úgy, mint az ember folyamatos önfelszabadításának folyamata. A nyelv, a művészet, a vallás, a tudomány különböző fázisai e 
folyamatnak. Az ember mindezekben egy új hatalmat fedez fel s mutat föl - azt a hatalmat, hogy képes felépíteni a saját világát, egy 'eszményi' világot.”418

Mindaz, amit mindennapjaink során magunk körül látunk, meghatározza az elménkben megkonstruált képeinket is. Környezetünk milyensége kihat a belső képalkotó képességünkre, ezáltal a gondolkodásunkra is hatást gyakorol. Az információk látás útján történő befogadásának manipulációja, megzavarása tehát bizonyos esetekben akadályozhatja, torzíthatja belső képeink és ezzel együtt gondolataink megalkotását. Az agyunkban leképeződésre váró idegi információ mentális leképezésének manipulálására tehát úgy is tekinthetünk, mint az akarati szabadság lehetőségének megvonására.

A látás szabadságát definiálhatjuk úgy, mint a korlátozások és zavaró tényezők kiiktatását a szem mint érzékszerv használatának folyamatából, de úgy is mint a szemünk elé táruló látvány feldolgozási, értelmezési folyamatának szabadságát, amely szoros összefüggésben áll döntési és ítélkezési folyamatainkkal.

A gondolati szabadságunkat veszélyeztető, képi jelekként testet öltő manipulatív törekvések alól viszont egyelőre csak olyan áron vonhatjuk ki magunkat, ha vállaljuk a társadalomból való kiszakadás következményét. Ahhoz, hogy e következmény nélkül is megvalósítható legyen a látás szabadsága és ezáltal a gondolkodás szabadsága, társadalmi párbeszédre, megoldási javaslatokra van szükség.

\section{A fejezet összegzése: Irányított tekintet, manipulált figyelem}

Korunk emberének életét meghatározzák a képek. Olykor egészen nyilvánvaló és jól körvonalazható érdekek mentén irányítják, máskor pedig egyszerüen csak sodorják egy meghatározhatatlan cél felé.

A szavak képekkel való felcserélhetőségét és a képi kommunikáció sikerességét illetően kétféle nézponttal találkoztunk a szakirodalomban. Az egyik álláspont szerint a képek önmagukban nem hordoznak jelentést, csak azáltal tesznek rá szert, hogy a nyelv által meghatározott kontextusokban kerülnek alkalmazásra. A másik álláspont szerint a képek éppen, hogy képesek megmutatni mindazt, ami a fogalmi gondolkodásnak ellenáll. Anélkül, hogy e régre visszanyúló vitát eldöntenénk, egy változástényezőt mindenképp regisztrálhatunk. A tünetek azt mutatják, hogy egyre többen egyre több információt próbálnak a képek útján közölni - és ez az egyik fontos motivációs tényező, amely a hétköznapi, privát fotók számának

\footnotetext{
${ }^{418}$ Cassier, Ernst: An Essay on Man. New Haven: Yale University Press, 1944. Idézi: Hankiss Elemér: Az emberi
} kaland. Helikon Kiadó, 1998. 43. 
megugrása mögött áll. Amennyiben nem csupán az önmagában álló, egyszeri képet tekintjük, hanem a képek együttesével és egymásutániságával is számolunk, akkor elképzelhető, hogy a képek nyelve a technikai lehetőségeknek köszönhetően egyre inkább alkalmas lesz a kommunikációra. Azt viszont semmiképp sem jelenthetjük ki, hogy a helyzet már tökéletesen megérett arra, hogy a képek véglegesen átvegyék a szavak helyét.

A vizuális kommunikáció folyamatában számos problémakört diagnosztizálhatunk, melyek mind az információ manipulálódása felé mutatnak: Az információáramlás sebessége miatt a vizuális jelek, kódok értelmezése a ma embere számára nehezebb, mint elődei számára volt. A jelek és jelrendszerek egy emberöltőn belül többször is átalakulnak, ráadásul ki vannak szolgáltatva a kereskedelmi érdekeknek, a fogyasztói társadalom sodrásának. A szimbólumok, jelképek iránt van ugyan egy felfokozott érdeklődés, ám azokat sokszor helytelenül, vagy éppen csak dekorációs céllal használjuk, megfosztva őket jelentésüktől. Abban a képi kommunikációs térben tehát, amelyben privát fotóink próbálnak hatni, igen sok zavar tapasztalható. E zavar okozza a céltalan sodródást a képek univerzumában.

Más esetekben azonban tetten érhető a manipulációs szándék, a média agresszorként való fellépése, melynek a közvélemény uralása, irányítása alá vétele jelenti a célját. Ennek számos eszköze van: témaválasztás, figyelemelterelés, juxtapozíció, rezonancia-effektus, fő́áramlat-hatás, stb. A médiaagresszió meglehetősen fókuszban lévő téma, úgy a szakirodalomban, mint a közbeszédben. Van azonban egy másik problémakör is, amely jóval kisebb hangsúlyt kap, talán magától értetődősége okán: a befogadó figyelmének irányítása.

Eddig ugyan elsősorban a fotográfiákat vettem górcső alá, de ha a táguló vizuális portfóliók természetéhez kívánunk közel férkőzni, akkor ki kell tekintenünk a mozgóképre is, hiszen e portfóliók tartalmaznak videó-elemeket is.

A diskurzív, broadcasting-szerkezetű mozgóképes médium, a televízió révén kevesek irányították sokak látását. A néző csak olyan irányban és olyan sebességgel „tekinthetett” végig a híradóban, ismeretterjesztő filmekben ábrázolt, a természeti valóságot megmutatni hivatott dolgokon, ahogyan azt az operatőri és vágói munka lehetővé tette. A kameramozgások és a vágástechnika meghatározta, hogy mit lát a több ezer vagy több millió fös nézőtábor. A látásnak tehát egy speciális, befolyás alatt álló helyzete valósult meg e képsorok által. Professzionális müsorkészítők által előállított, hasonló anyagok az interneten, a videomegosztó portálokon is láthatók, melyekről ugyanez mondható el. Egyre növekszik azonban az amatőr mozgóképes anyagok száma, melyek ugyanúgy funkcionálnak, mint a privátfotók, amennyiben az egyén által látott, tapasztalt, megélt dolgokat hivatottak megmutatni a közösségi média valamely csoportjának. Ezek jellemzően kevéssé vannak szerkesztve és vágva, így bizonyos értelemben 
hitelesebb, bár nem feltétlenül jellemzőbb szeletet mutatnak meg a valóságból. Másfelöl viszont éppen e szelet-létükben rejlenek a manipuláció veszélyei, a kiragadás révén lehet egészen más színben feltüntetni a dolgokat, mint amilyennek azok a valóságban, a dolgok közegében tünnek. Emellett e mozgóképsorokra is sokan alkalmazzák azokat az eszközöket, effekteket, amelyekröl a fotók kapcsán már volt szó - bár ezeket mozgóképen lényegesen nehezebb alkalmazni. (És létezik egy réteg a professzionális mozgóképgyártás és a rövid, telefonnal felvett videók világa között is: a vloggerek világa, akik bárki számára hozzáférhető eszközökkel, de sok vágással, trükkel, effekttel dolgoznak.)

A vizuális portfóliók tehát a mozgóképes anyagok irányába is tágulnak, és mind a bennük lévő fotók, mind a videók rejthetnek magukban szándékos vagy szándéktalan manipulációt, amely irányulhat kifelé, mások megtévesztésére, de irányulhat a portfólió alanyára is. A következő fejezet ez utóbbi esetet vizsgálja, arra keresve a választ, hogy képekből összerakott sors hogyan hat ki az alany sorsára a valóságban, illetve hogyan befolyásolhatja emlékezetén keresztül - identitását. 


\section{A képekből összerakott ember}

„A látás tanulása kritikai folyamat, amely egyidejüleg irányul olyan elfedések ellen, amelyek eltakarják elölünk a képeket, valamint olyanok ellen, amelyektöl viszont magunkat nem látjuk." 419

Oskar Bätschmann

Az előző fejezetekben láthattuk, hogy az ember képekhez való viszonya alapvetően változott meg a fényképezés eljárásának felfedezésével, majd a képek digitalizálódásával. A képkészítés és készíttetés szükségletként jelentkezik, egyre nagyobb szerepet tölt be a mindennapi kommunikációs aktusokban, miközben a képekbe kapaszkodó ember a képek teremtette manipulatív viszonyrendszerekben a képek által irányíthatóvá is válik. Mindez szükségszerüen elvezet annak a kérdésnek a feltevéséhez, hogy önképére miképp hatnak? E hatás eredménye feltételezésem szerint leírható a képekből összerakott ember metaforájával, tekintve, hogy a képek meghatározóan befolyásolják azt, amit önmagáról gondol, hatnak önképének pszichológiai, fizikai, szociális és kulturális komponenseire.

A dialogikus médiatérben realizálódó vizuális portfóliók bizonyos értelemben az egyének mitológiáinak is tekinthetők, míg korábban a papírképeket általában családi albumokba gyüjtötték, tehát egy kisebb közösségnek a mitológiáját alkották. A közösségi oldalakon - a rendszer sajátosságaiból adódóan - mindenki egyénként van jelen, és tölti fel képeit. Ahogy arról már korábban szó esett, e képek egyre nagyobb hányadát teszik ki az önportrék, a selfie-k. Mindez azt jelzi, hogy az individuum erőteljesen szeretné megmutatni, felmutatni önmagát.

Korábban már taglaltuk, hogy a vizuális dokumentáció elemei valamiféle szükséglettől vezérelve keletkeznek, s e szükséglet mögött tetten érhetjük a szemlélést mint élvezetet, és azt az élvezetet, amelyet az az állapot nyújt, amikor mások szemlélnek minket. A pszichoanalitikának egyik fontos kutatási területe a vizuális élvezet: Jacques Lacan elméletét például gyakorta felhasználják a vizuális kultúra különböző megközelítéseiben is. Ö Freud nyomán úgy véli, hogy egyes látványok a szexualitás mellett a szubjektivitás alakulásában is centrális szerepet töltenek be. ${ }^{420}$ Gillian Rose szerint megtanulunk bizonyos módokon látni, és ez a folyamat megismétlődik, valahányszor ránézünk valamire. Ha elmerülünk egy bizonyos típusú vizualitásban, vagy bizonyos típusú vizuális képekkel találkozunk, az meghatározott

\footnotetext{
419 Bätschmann, Oskar: Bevezetés a müvészettörténeti hermeneutikába. Corvina, Budapest, 1998. 57.

${ }^{420}$ Lacan, Jacques: The Four Fundamental Concepts of Psychoanalysis. London, Hogart Press, 1977.
} 
szubjektivitásra nevel bennünket. ${ }^{421}$ Ebből kiindulva a továbbiakban fontos megvizsgálni, hogy a vizuális dokumentációképzés milyen viszonyban áll a szubjektivitással és az identitással. A szubjektum-megközelítések közül jelen esetben az a pszichofizikai szubjektum lényeges, amelyik intencionális aktusok hordozója, egy testi-lelki egység, amely megismerően, törekvően és érzően egy tárgyra irányul. E szubjektum jellemezhető azzal, hogy mentális képeket alkot, és ahogy korábban már szintén szóba került: e mentális képekre erőteljesen hatnak a fizikai képek. E hatással foglalkozik a következő fejezet, amely elsősorban a fotók és az emlékezet kapcsolatából kiindulva vizsgálja meg kép és identitás kapcsolatát - először az egyénre, majd a közösségre vonatkoztatva.

\section{IV.1. A vizuális média mint az emlékek őre}

„A történelem az az üllö, amelyen az identitást kovácsolják, az emlékezet pedig a legkülönbözöbb kijelentések és következtetések hivatkozási alapja, legyen szó nemzetröl vagy egyénröl. A populáris emlékezet és a populáris történelem kérdése elötérbe kerül, mivel ez az a nem hivatalos tudás, amely fölött a média az úr. A média felkínálja a múltról alkotott saját verzióját, amely persze saját múltunk láthatóvá tett változata." $" 422$

Roger Silverstone

\section{IV.1.1. A technikai memória előtérbe kerülése}

Ha a hordozó felől közelítünk az emlékekhez, vagyis az emlékezetet mint valahol elhelyezésre kerülő „lerakatot”, halmazt tekintjük, akkor beszélhetünk belső és külső, természetes és mesterséges emlékezetről, orális kultúrán alapuló, illetve technikai emlékezetről. Merlin Donald - aki evolúciós szempontból közelít a vizuoszimbolikus gondolkodás memóriaszközeihez - úgy véli, a külső emlékezetet legjobban funkcionális értelemben lehet meghatározni. Ebből a szempontból pedig a külső emlékezet ,a belső vagy biológiai emlékezet pontos külső hasonmása, nevezetesen tároló- és visszakereső rendszer, mely lehetővé teszi az emberek számára a tapasztalat és a tudás összegyüjtését”. Ily módon az ember kollektív emlékezeti eszközeinek tartja a „fizikai természetü” alkotásokat. ${ }^{423}$

\footnotetext{
${ }^{421}$ Rose, Gillian: Pszichoanalizis: vizuális kultúra, vizuális élvezet, vizuális széthullás. In: Blaskó - Margitházi: Vizuális kommunikáció szöveggyüjtemény. Typotex, 2010. 217.

${ }^{422}$ Silverstone, Roger: Miért van szükség a média tanulmányozására? Akadémiai kiadó, Budapest, 2008. 149.

${ }^{423}$ Donald, Merlin: Az emberi gondolkodás eredete. (Ford.: Kárpáti Eszter). Budapest, Osiris Kiadó, 2001. 271272.
} 
A technikai memóriát a nyomot hagyni vágyó ember hozta létre, aki biztosra akart menni azt illetően, hogy emlékeit a saját élethosszán túlra is kiterjesztheti. A múlandó dolgok konzerválásának lehetősége az idő egyfajta uralásának képzetét kelti: azon fontos események, amelyek velünk történtek, a jövőben is biztosan tovább élnek majd, nem merülnek feledésbe. Ilyen „mankók” voltak a mesék, a mítoszok, a krónikák, a legendáriumok, majd később a naplók, emlékiratok, történelemkönyvek. Az ember megpróbálta előbb szájhagyomány útján, majd írásban rögzíteni és továbbadni emlékeit - noha a testre mint élő emlékezetre leselkedő veszély már az írott emlékezet kapcsán is felmerült. Antik Sándor felhívja a figyelmet arra, hogy a technikai emlékezet „használata és elterjedtsége a Földön távolról sem mérhető a szóbeliség reális szerepköréhez. A mesterséges emlékezet jövőbeli hatásait ma még nem mérhetjük fel valójában." ${ }^{2424}$ Antik, könyvében mindezt Sugár János meglátásával egészíti ki: „az emlékezés történetében a technikai emlékezés egy viszonylag újkeletű fejlemény, miközben az eddigi emberi civilizációt, kultúrát a megőrzés és a felejtés egy teljesen más paradigmája jellemzi." ${ }^{425}$ Az írott krónikák, lejegyzett adatok mellett a kezdetektől fogva óriási jelentősége volt az emlékek képi megragadásának - hiszen az önmagunkban, belül őrzött emlékek nagyrészt szintúgy vizuális összetevőkből állnak. Ha emléket idézünk, többnyire képeket idézünk - amelyekhez természetesen kapcsolódhatnak hangok, szavak, történetek, ízek, illatok, érzelmek és hangulatok.

A mai ember számára nehéz elképzelni, milyen lehetett az, amikor az emlékezetet nem segítették fizikai képek százai, amikor csak az agyból lehetett előhívni a múlt élménygazdag pillanatait, vagy éppen azon személyek arcvonásait, akik közel álltak hozzánk.

A fotográfia feltalálása előtt a jeles személyiségek, fontos események, nagy dolgok képi ábrázolása, és az ábrázolás általi megőrzés feladata kétségkívül a (mai értelemben vett) képzőművészetre (illetőleg a „képíró” mesterekre) hárult. Az állítást viszont nem tudjuk megfordítani, és nem jelenthetjük ki, hogy a képzőművészet mindig feladatának tekintette volna a látható valóság objektív, élethü leképezését. A müvészi ábrázolás és a valóság képi megragadásának szándéka a történelem bizonyos pontjain találkozik, egybeesik, máskor pedig élesen különválik egymástól. Annyi azonban bizonyos, hogy a leképezés lehetősége - a müvészi alkotások létrehozásának igényétől függetlenül is - fontos témája volt az emberi gondolkodásnak attól a pillanattól, amikor nyilvánvalóvá vált, hogy a tapasztalt látvány

\footnotetext{
${ }^{424}$ Antik Sándor: Vizuális emlékezet és képi metaforák. Egyetemi Mühely Kiadó, Bolyai Társaság - Kolozsvár, 2008. 12.

${ }^{425}$ Sugár János: Opponensi vélemény Antik Sándor A memória szemantikus értelmezései és metaforikus képei a müvészetben címü DLA-értekezéséröl. Idézi: Antik Sándor: Vizuális emlékezet és képi metaforák. Egyetemi Mühely Kiadó, Bolyai Társaság - Kolozsvár, 2008. 12.
} 
másolata kirajzolódhat emberi közbeavatkozás nélkül is, a fizika és a természet törvényszerűségeinek köszönhetően. Mint tudjuk, Arisztotelész a napfogyatkozás megfigyelése kapcsán tapasztalta, hogy a Hold által eltakart Nap oldalfordítottan, fejjel lefelé, megtöbbszörözve látható a földön - rájött, hogy e képeket a sűrü levélzet résein beszürődő fény okozza. Ez a jelenség a később camera obscurának nevezett szerkezet müködési elve, melynek lényege, hogy egy sötét dobozba vagy kamrába egy apró lyukon keresztül fény hatol be, amely a lyukkal ellentétes oldalon fordított állású képet rajzol ki. Az állam címü müvének hetedik könyvében Platón egy hasonló jelenségből indítja barlanghasonlatát: a megbéklyózott emberek a barlang bejáratának háttal ülve, az átellenes falon látják azokat az árnyakat, melyeket a tüz fénye odavetít. ${ }^{426}$ A hasonlatból persze egyértelművé válik, hogy a vetített kép nem a valóság, csupán egyfajta látszat. Ám a látszat, a látható valóság kivetült képének tartóssá tétele mégis sokakat tart lázban egészen a fényképészeti eljárások feltalálásáig, még akkor is, ha a camera obscura-jelenség által létrejövő képek mindig kissé homályosak, fordított állásúak és oldalhelytelenek.

Különböző korokban, a világ különböző pontjain tanulmányozzák a tudósok, gondolkodók ${ }^{427}$ a fény által teremtett képet, hiszen a camera obscura lehetőséget ad a természeti jelenségek és a fizikai törtvényszerüségek tanulmányozására, másrészt eszközt biztosít a reneszánsz képzőművészet térhódításától jelen lévő új igények kielégítéséhez: a természet imitálásához, az egyéni arcvonások hủ megragadása által az individuum konzerválásához. Tudjuk, hogy ezt az optikai berendezést a reneszánsz számos művésze, köztük Leonardo da Vinci is használta mint rajzolási segédeszközt. Leone Battista Alberti és Albrecht Dürer is terveztek rajzolókészülékeket. ${ }^{428}$ A valóságban tapasztalt jelenségeket élethủen bemutató festmények létrehozásához különféle egyéb eszközöket is bevetettek: négyzetrácsokat használtak a pontos arányok meghatározásához, különféle tükröket és lencséket ${ }^{429}$ a látvány vászonra vetítéséhez.

\footnotetext{
${ }^{426}$ Platón: Az állam. Gondolat Kiadó, Budapest, 1988. 264-265.

427 Kr. e. 20 körül Pollio Vitruvius római építész De architectura című művében bemutat egy általa spectaculumnak nevezett eszközt, melynek müködési elve megegyezik a később camera obscurának nevezett eszközével. Ibn Al Haytam (Alhazen) egyiptomi arab természettudós 997-ben írt Opticae Thesaurus címü könyvében ismerteti ezt az elvet. Roger Bacon angol ferences gondolkodó az 1200-as évek derekán, a Perspektiva és a De multiplicatione specierum címü könyveiben beszámol lyukkamerával végzett kísérleteiről. V.ö.: Varga Gábor: Camera Obscura. In: Szellemkép művészeti folyóirat, 2001/3.

${ }^{428}$ Horváth Árpád: Camera obscura. A fényképezés és a film története. Táncsics Kiadó, Budapest, 1965. 9.

${ }^{429}$ Erre mutat rá például Martin Kemp (The Science of Art: Optical themes in Western Art from Brunelleschi to Seurat. New Haven: Yale University Press, 1990.) vagy David Hockney (Titkos tudás. A régi mesterek technikájának újrafelfedezése. Officina'96 Kiadó, Budapest, 2003.) Elméleteik ugyan vitatottak, de e viták inkább a pontos metódusokkal kapcsolatosak, az eszközhasználat elterjedtségének tényét nem vonják kétségbe.
} 
Az így született valóság-szeleteket azonban a festőmüvészek kiegészítették, kibővítették mindazzal, amit hitük szerint hozzá kellett tenniük az alkotáshoz. Akár magával a müvészetet megtermékenyítő illúzióval is. ${ }^{430}$ Így váltak többé, mint puszta másolat és így váltak ugyanakkor kevesebbé, hiszen az emberi tényezőt nem iktathatták ki. Emlékezetre gyakorolt hatásukban éppen emiatt még érvényesül valamiféle szelekció, cenzúra, lényegletisztulás, hiszen ma olyannak látjuk, amilyennek az alkotó szerette volna megmutatni őket az utókor számára.

Ahogyan azt a II. fejezetben áttekintettük, a XIX. század elején elérkezett az idő, amikor tömeges igény támadt a valóság-másolatokra, a művészi ambíció nélküli, dokumentáló jellegü képekre. Persze akadtak olyanok is, akik a képalkotást továbbra is szellemi műveletként fogták fel, azt a mentális kép kivetüléseként értelmezték, és „kétségbe vonták azt, hogy a technikai képpel meg lehet ragadni a lényegest és értelmezni lehet a látványt.”431 Innentől tehát lényeges és lényegtelen egyaránt fennmarad, ráadásul egyre növekvő mennyiségben.

Az információs forradalom tekinthető az emlékezet forradalmának is. Az elmén kívül, külső hordozókon félelmetes részletességgel tárolt múlt, a feledés lehetőségének kiiktatása merőben új helyzet elé állítja az emberiséget. Roger Silverstone megállapítja, hogy „mind a kollektív, mind a személyes emlékezet tárggyá vált, amit tanulmányozni, kutatni, megkérdőjelezni és elemezni egyaránt lehet.” Felhívja a figyelmet a média emlékezetre gyakorolt hatására is, hiszen ,a médiának hatalmában áll meghatározni a múltat: bemutatni és reprezentálni." 432

\section{IV.1.2. A technikai képek szerepe az emlékezet narratívájában}

Az emberi emlékezet olyan többkomponensü rendszer, amely az információk tárolására és előhívására jött létre. Empirikus módszerekkel csak bő száz éve kutatják, így nehéz megkérdőjelezhetetlen állításokat megfogalmazni vele kapcsolatban, hiszen, ha leegyszerüsített, laboratóriumi körülmények között vizsgálják, akkor igazán jelentős, a valóság problémáira is alkalmazható következtetések nem születhetnek. Ellenőrizetlen, hétköznapi körülmények között viszont lehetetlen maradéktalanul objektív megfigyeléseket tenni. A modern pszichológiai megközelítés egyik utat sem veti el, hanem a kettőt párhuzamosan használva próbál közelebb kerülni az emlékezet természetéhez. A korszerü képalkotó

\footnotetext{
${ }^{430}$ Lásd Ernst H. Gombrich: Illúzió a természetben és a müvészetben címü müvét. Gondolat, Budapest, 1982.

${ }^{431}$ Antik Sándor: Vizuális emlékezet és képi metaforák. Egyetemi Mühely Kiadó, Bolyai Társaság - Kolozsvár, 2008. 46.

${ }^{432}$ Silverstone, Roger: Miért van szükség a média tanulmányozására? Akadémiai kiadó, Budapest, 2008. 145.
} 
eljárásokkal és különféle kísérletekkel számos agyi mechanizmusra fény derült az utóbbi évtizedekben, ám még mindig nem tudjuk egészen pontosan, hogy mitől függ egy emléknyom bevésődésének erőssége és részletessége, hol, hogyan és meddig tároljuk, mikor és miért hívjuk azt elő. Az emlékezet természete - és a hozzá kapcsolódó problémakörök, mint például a digitális nyomhagyás, vagy a mediális eszközökkel őrzött és azok segítségével előhívható emlékek hatásmechanizmusai - azonban nem csak a modern neurobiológia számára jelent kihívásokat. A téma (ismét) visszatérni látszik a bölcsészettudományokba ${ }^{433}$, és a folyamatosan zajló természettudományos kutatásokra odafigyelve - de nem csupán azok opcionális, egyszer majd talán megszülető válaszaira alapozva - egyre többen elidőznek az emlékezettel összefüggő kérdések körül.

Az emlékezet fogalmához sokféleképpen közelíthetünk. Tekinthetjük az asszociációs képesség egy elemének, azonosíthatjuk a tudattalanból reprodukált képzetekkel. A különféle megközelítések azonban közösek abban, hogy képességnek tekintik és folyamatként írják le. E képesség birtoklója befogadja és kódolja, majd tárolja, később pedig megfelelő inger hatására előhívja az emléket. Az emberi emlékezetről ma már azt is tudjuk, hogy az agy több területe vesz részt benne.

Megkülönböztetünk szenzoros, rövid-és hosszútávú emlékezetet. Alan Baddeley szerint a legrövidebb emlékezeti tárolás csupán a másodperc töredékéig tart, ezért ezt célszerü az észlelési folyamat részének tekinteni. ${ }^{434}$ A rövid távú emlékezet ideiglenesen, néhány másodpercig tartja fenn a látott információt egy bizonyos állapotban. Ezek mellett azonban rendelkezünk a hangok és képek hosszútávú emlékezeti megtartásának képességével is: a látott inger egy stabilabb, hosszútávú emlékké alakul, s egyúttal tudatosul. Számunkra jelen esetben ez a hosszútávú memória érdekes, azon belül is az explicit, vagyis a szándékos előhívás során hozzáférhető emlékezet. Ennek két összetevője van: az egyedi, individuális eseményeket őrző epizodikus emlékezet, illetve a világról való tudásunkat, ismereteinket tároló szemantikus emlékezet. ${ }^{435}$

Az információkat érzékszerveinken keresztül sajátítjuk el. Az emlékezet tárgya az emlék, az észleleteink lenyomata, az emlékezetben megörzött tudattartalom ${ }^{436}$, amely igen nagy részben áll vizuális természetü összetevőkből - hiszen az információk túlnyomó többségét látás

\footnotetext{
${ }^{433}$ Lásd: Laczkó Sándor (szerk.): Lábjegyzetek Platónhoz 15. Az emlékezet. Pro Philosophia Szegediensi Alapítvány, Magyar Filozófiai Társaság, Státus Kiadó, Szeged, 2017.

${ }^{434}$ Baddeley, Alan: Az emberi emlékezet. Osiris Kiadó, Budapest, 2005. 28.

${ }^{435}$ U.o. 28.

${ }^{436}$ Antik Sándor: A memória szemantikus értelmezései és metaforikus képei a müvészetben. DLA értekezés, Magyar Képzőművészeti Egyetem Doktori Iskola, 2008. 23.
} 
útján nyerjük. Ha emléket idézünk, többnyire képeket idézünk, amelyekhez természetesen kapcsolódhatnak hangok, szavak, történetek, ízek, illatok, érzelmek és hangulatok.

A vizuális emlékezet természete a filozófusok érdeklődési körétől sosem esett távol. Johann Andreas von Segner 1740-es évekbeli, ikonikus emlékezetet ${ }^{437}$ érintő kísérleteiből kiindulva például Sir William Hamilton is tanulmányozta a vizuális emlékezet mennyiségi kapacitását. (Itt érdemes megemlíteni, hogy egyes feltevések szerint vannak személyek, akik eidetikus, vagy más elnevezéssel fotografikus memóriával rendelkeznek, azaz képesek akár az észlelt képek tömegét is extrém pontossággal, specifikus részleteiben is felidézni, úgy látni, mintha az észlelés tárgya még mindig elöttük lenne - bár ezzel kapcsolatban sok a szkeptikus hang is a tudományos világban.) Raymond S. Nickerson kísérletei például igazolták, hogy a kísérletbe bevont személyek még az inger bemutatása után egy évvel is 63\%-ban ki tudták választani a korábban látott képet az új, teljesen ismeretlen képek közül. ${ }^{438}$

Antik Sándor szerint „,a megőrzés mértéke függ a megerősítő élménystimulusoktól, amelyek segítenek a képzetek sémáinak kialakításában (kódolás), illetve az emlékkép mentális felidézésében (dekódolás). Van, amit hamarabb elfelejtünk, és van, ami beépülhet a viselkedésünk automatizmusaiba." ${ }^{439}$ Antik rámutat a figyelem szelektáló és irányító szerepére is.

Ahogyan azt az első fejezetben láthattuk, az emlékképek a mentális, vagyis az értelmi, észbeli képek csoportjába tartoznak. A tudatban rögzülnek, és felidézhetők onnan. A repreneztációs látáselmélet hívei a XX. század második felében még úgy vélték, hogy az érzékleti képnek az agy nyakszirti lebenyében található egy reprezentánsa. Az elmélet cáfolói viszont azt feltételezik, hogy a leképezett tárgy retinaképének nincs pontos és teljes reprezentánsa az agyban. Az érzékleti kép csupán kiváltója az észlelésnek, és a látás hátterében álló bonyolult biológiai és idegrendszeri mechanizmusok, mentális folyamatok során a látvány többszörösen átkódolódik. A mentális - és így az emlékezeti kép is - tehát egészen más természetü, mint az optikai. Az új felfogás az érzékelt képet optikai minőségként, a mentális képet átkódolt minőségként értelmezi. ${ }^{440}$ „Az emberi agyban két nagy pályarendszer szolgálja a látási folyamat információit: az egyik a térbeli tájékozódás, a dolgok térbeli betájolásának, a tárgy mozgásának és a tárgyra irányuló cselekedeteknek az információit hordozza, míg a másik

\footnotetext{
${ }^{437}$ Az ikonikus emlékezet tárgykörébe tartoznak azok a milliszekundumos emléknyomok az előző vizuális képről, amelyet az utána következö ingerek könnyen „maszkolnak”.

${ }^{438}$ Baddeley, Alan: Az emberi emlékezet. Osiris Kiadó, Budapest, 2005. 37.

${ }^{439}$ Antik Sándor: Vizuális emlékezet és képi metaforák. Egyetemi Mühely Kiadó, Bolyai Társaság - Kolozsvár, 2008. 35 .

${ }^{440}$ U.o. 33.
} 
a tárgy alakjának, színének, tömegének, sajátosságainak információ-hordozásáért felelős"441 _ mutat rá Antik Sándor, hozzátéve, hogy e mentális müveleteket automatikusan végezzük el, és végeredményképpen egy egységes képet észlelünk. Arról, hogy a műveletek hogyan, milyen kódrendszer szerint integrálódnak, még keveset tudunk. Arról pedig még kevesebbet, hogy a fejünkben lévő képtár hogyan müködik, mi történik akkor, amikor egy emlékképet előhívunk. Az viszont nyilvánvaló, hogy a mentális képek másképp „,müködnek”, mint a képek családjának más tagjai. Nem rendelkeznek az észleleti kép részletgazdagságával, pontosabban az észleleti képből csak azokat a részleteket jelenítik meg, amelyek a kép létrehozója számára fontosak, ráadásul e részletek és attribútumok folyamatosan változhatnak egy szubjektív folyamat keretében - ezért nevezhetők dinamikusaknak.

Fontos még megemlíteni a szellemi emlékezet fogalmát. Walter Brugger filozófiai lexikonja ezt kifejezetten az ember sajátjának tekinti, mint a megértés és az akarat egyéni szellemi aktusát, amelyhez nem elég a párhuzamosan rendelkezésre álló érzéki képzet, hanem szükséges hozzá a gondolatok társítása is. ${ }^{442}$ Az így felfogott emlékezet az identitáselőfeltétele, segít kijelölni a helyünket az időben és a térben. Természete dinamikus, aktív formálóerőként müködik: amit megpróbál kilökni magából, az éppolyan fontos, mint az, amit elraktároz. ${ }^{443}$ Ebből következik, hogy hamis emlékezet gyakorlatilag nincs, hiszen velejárója a változás, mindig egy kicsit másképp idézzük fel a történteket - szelektáljuk, megmásítjuk azokat, énképünk formálódásával párhuzamosan. James E. Young holokausztkutató szerint az emlékezet munka eredménye, meg kell érte küzdeni. E küzdelem nem egy vákuumban zajlik, és a motivációi sosem teljesen világosak. ${ }^{444}$

A továbbiakban a hosszútávú, szándékosan előhívható, szellemi emlékezet technikai képekkel, illetve vizuális médiával alkotott relációját vizsgáljuk meg alaposabban, arra keresve a választ, hogy mi történik, ha a szellemi emlékezet egyfelől külső tárhelyekre helyeződik át, másfelől e külső tárhelyeken képződik meg. Hiszen két fontos tünetet regisztrálhatunk: az emberek elképesztő mennyiségű emléket, fotókat, videókat gyártanak a jelenről, de közben a már letűnt múltat is megpróbálják új képekbe önteni - például játékfilmek és dokumentumfilmek formájában.

\footnotetext{
441 U.o.

${ }^{442}$ Brugger, Walter: Filozófiai lexikon. Szent István Társulat, Budapest, 2005. 115.

${ }^{443}$ V.ö.: Samuel, Raphael: Theatres of memory 1.: Past and Present in Contemporary Culture. London, Verso, 1994.

${ }^{444}$ Young, James E.: The Texture of Memory: Holocaust Memorials and Meaning. New Haven, CT, Yale University Press, 1993. 2.
} 
A média és az emlékezet viszonyának vizsgálata során igen lényeges kérdés lesz az, hogy az egyes képek milyen módon reprezentálják, milyen mértékben határozzák meg a múltat. Egészen más módon hat egy kimerevített pillanatot ábrázoló fotó, mint egy dokumentatív, vagy éppen a múlt illusztrálására hivatott, de fikciós mozgóképsor. A képek és az idő viszonylatából fakadó problémák érintőlegesen már az előző fejezetekben is előkerültek, hiszen az a mód, ahogyan a kép kifejezheti az időt, meghatározza és behatárolja a narrativitás lehetőségeit is.

Kibédi Varga Áron, miközben az (álló)képek kapcsán arra keresi a választ, hogy létezike autonóm vizuális narráció, vagy az mindig függ a szövegtől, esetleg a kép címétől - a történet, ezáltal az időbeli kiterjedtség lehetőségeit is vizsgálja. Úgy véli, narrativitással nem csupán a képsorok vagy a pluroszcenikus, vagyis több jelenetet ábrázoló egyedi képek, de a monoszcenikus egyedi képek is rendelkeznek. Rámutat, hogy az európai festészetben nagy hagyományai vannak a punctum temporis, azaz a központi pillanat megragadásának, vagyis annak, hogy egy cselekménymozzanatból azt a pillanatot rögzítse a kép, amely a leküzdött nehézségek maradványát, de egyúttal a megoldás irányát is sejteti. ${ }^{445}$ Ilyen esetben tehát egyetlen kép képes magába süríteni egy egész eseménysort, reprezentálni egy jelenséget. Ám ha a kimerevítés pillanata nincs ilyen gondosan kiválasztva, akkor más a helyzet. Az emberi arckép inflációja kapcsán már volt róla szó, hogy Gombrich szerint mást jelent az élet csendéletként való megragadása, és mást a vonások kimerevítése egy olyan pillanatban, amely az események sodrában nem is tudatosul, és az előzmények nélkül nehezen értelmezhető: például a pislogás, ásítás, tüsszentés közben lefotózott ember furcsa arckifejezése utólag félreérthető. $^{446}$

Az állókép emlékezetre gyakorolt hatása tehát összetett és bizonytalan kimenetelü. Egészen más múltat mutat egy gondosan és tudatosan megválasztott pillanat ábrázolása, mint egy véletlenszerüen elkapotté, és hogy melyik hitelesebb, az nézőpont kérdése. Az azonban bizonyos, hogy minkettő hat valamilyen módon a természetes emlékezetre még akkor is, ha az alany az öt ábrázoló, a múltban készült képet is mindig másképp, másnak látja. Hiszen a befogadási folyamat temporális eseményét a szubjektum élettapasztalatainak, szemléletének, világlátásának változásai mindenkor befolyásolják és módosítják, ezért a technikai kép emlékezetre gyakorolt hatása is változó.

A befogadásnak ez a relativitása jellemző a mozgóképre is, ám kijelenthetjük, hogy a film, a videó az egyedi állóképnél komplexebb, ezáltal az emlékezetet jobban meghatározó

\footnotetext{
${ }^{445}$ Kibédi Varga Áron: Vizuális argumentáció és vizuális narrativitás. In: Athenaeum, 1993. I./4. 169.

${ }^{446}$ Gombrich, Ernst: The Mask and the Face: The Perception of Physiognomic Likeness in Life and Art. In: Art, Perception and Reality. The Johns Hopkins Univercity Press, Baltimore, 1972. 16-17.
} 
szeleteket őrizhet meg (illetve fikciós és illusztratív filmes müfajok esetén konstruálhat meg) a múltból.

Az első filmekben - gondoljunk például arra a mozgóképsorra, amit a Lumière-fivérek rögzítettek a gyárat elhagyó munkásokról ${ }^{447}$ - alig van vágás: azok a történések egy bizonyos részletét teljes terjedelmében rögzítik. A mozgóképes illúzió újdonságának, a képek életre kelésének bűvölete utáni időszakban viszont a montázs felfedezése a filmnyelv sajátos lehetőségeit hozza. Gazdagodása nyomán ,az emlékezetünk nem csak fázisképek összekapcsolt sorozatát menti el, hanem montázsmondatokat, ritmusokat, filmgondolatokat is." 448 - írja Antik Sándor. Mint az előző fejezetben láttuk, a mozgóképes tartalmak készítői is vezetik a szemet, és a belölük gyüjtött tapasztalatok messze nem azonosak a természeti valóságból szerzettekkel. Az azonban kétségtelen, hogy a fotókhoz képest még jobban megkötik a természetes emlékezet szelekciós munkáját, még erősebben gátolják a feledést.

A napjaink videomegosztó portáljain látható anyagokban ráadásul ismét kevesebb a tudatosság, mint a professzionális filmekben, tehát abból a szempontból rokoníthatók a korai mozgóképsorokkal, hogy kevésbé manipulálják a látványt, kevésbé érvényesül rajtuk tudatos szelektálás és lényegkiemelés. A természetes emlékezetet tehát valamennyi mesterséges hordozó közül talán ezek, az újmédia felhasználói által közzétett mozgóképes tartalmak tartják leginkább befolyásuk alatt.

A dokumentáló mozgókép mellett azonban ott van az illusztratív, vagy fikciós tartalmú is: a múltat dokumentumfilmek és játékfilmek révén is igyekszik elénk tárni a média. A vizuális élmény kedvéért a dokumentumfilmek is gyakran tartalmaznak illusztrációként felvett és bevágott képsorokat. A történelmi témájú játékfilmek pedig egy értelmezett múltat ábrázolnak - mást nem is tehetnek. A letűnt időket egyedi értelmezésben, ám többnyire mégis a hitelesség érzetét keltve tálalják a néző számára. Roger Silverstone úgy véli: Hollywood bezárja az emlékezetet. A Spielberg rendezte Schindler listája vagy a Ryan közlegény megmentése címü filmek kapcsán felveti, hogy akiknek már nincsenek személyes emlékeik a mögöttük húzódó eseményekről, azok a filmre fognak emlékezni. „Számukra már ez a film lesz a holokauszt.” írja Silverstone a Schindler listája kapcsán. ${ }^{449}$

Végezetül a különféle típusú képek hatásának összeadódásával is számolnunk kell. Egyfelől nem hagyhatjuk figyelmen kívül Manovich már idézett megállapítását, hogy egy

\footnotetext{
${ }^{447}$ A munkaidő vége címü, 46 másodperces képsort a Lumière-fivérek Lyon-ban, a Saint-Victor úton, saját üzemük előtt készítették 1895. március 19-én.

${ }^{448}$ Antik Sándor: Vizuális emlékezet és képi metaforák. Egyetemi Mühely Kiadó, Bolyai Társaság - Kolozsvár, 2008. 63.

${ }^{449}$ Silverstone, Roger: Miért van szükség a média tanulmányozására? Akadémiai kiadó, Budapest, 2008. 148.
} 
posztdigitális vizuális mezőben, hibrid képektől körülvéve élünk. A képek nagy részéhez hang is társul, amely tovább árnyalja az emlékezetre ható mechanizmusokat. Ugyanakkor az összeadódás nem feltétlenül jelent felerősödést. Visszautalva Silverstone példáira: ha az adott történelmi eseményekről többféle, eltérő felfogású adaptáció is készül, akkor egy film már nem tudja teljességében meghatározni a bennünk létrejövő vagy manipulálódó emléket. A képdömping tehát adott esetben gyengítheti is a manipulatív hatást.

A mediatizált képek emlékezetre és identitásra gyakorolt hatását a történeti és fogalmi áttekintés után azonban célszerü külön-külön megvizsgálni az individuális és a közösségi emlékezet vonatkozásában.

\section{IV.2. Individuális emlékek a vizuális média hatóterében}

„Emlékezetünk nem elefántcsont ereklyetartó egy pormentes múzeumban, hanem állat, amely él és zabál és emészt. Önmagát falja fel, mint a mondabeli fonnix, hogy tovább élhessünk és ne pusztuljunk el miatta." 450

Erich Maria Remarque

Az emberi emlékezettel kapcsolatos, különböző irányú kutatások két dologban általában megegyeznek: 1. az emlékezet szelektív, 2. sohasem lehet maradéktalanuk objektív. Arra, hogy mit és hogyan tárolunk, hatással vannak például a különféle önvédelmi mechanizmusok: bizonyos emlékképeket mélyen eltemetünk, másokat rendszeresen előhívunk. Az sem ritka, hogy az átélt történések emlékét gazdagítjuk, megváltoztatjuk, megszépítjük, vagy éppen csúfabbá tesszük. Végezzük e furcsa, nem tudatos munkát egyrészt a többnyire visszanyomozhatatlan és felfejthetetlen belső késztetéseinknek engedelmeskedve, másrészt a környezetünkből kapott benyomásokra való önkéntelen válaszreakcióként. Manipulálhatjuk az emlékeinket különféle megfelelési kényszerektől vezérelve, vagy egyszerüen csak azért, mert óhatatlanul megpróbáljuk azokat a korszellemhez, a környezetünkre jellemző értékrendhez, látásmódhoz igazítani. Addig, amíg mindezt egy belső munka révén tesszük meg, még beszélhetünk az emlékezet szabadságáról: arra és úgy emlékszünk, amire és ahogy akarunk, illetve, ahogy érzelmi és pszichés folyamataink megkívánják. De mi történik akkor, ha ebbe a belső munkába valaki kívülről ,,belenyúl”?

A szelekció, vagyis a részleges felejtés jelentősége elvitathatatlan. Z. Karvalics László figyelmeztet rá, hogy a felejtés mögött ugyanaz a funkcionalitás munkál, mint emlékezéskor:

\footnotetext{
${ }^{450}$ Remarque, Erich Maria: Éjszaka Lisszabonban. Magvető, Budapest, 1988. 153.
} 
jövőállapotokra és hatékony cselekvésre készít fel. A negatív tapasztalatok megfakításával csökkenti a mentális terhelést, vagy éppen lerövidíti a helyes döntések megtalálásához vezető utat. „Köztudott, de csak az extrém esetek kapcsán szokás kiemelni, hogy a felejtés létfontosságú funkció - hiányában működési zavarok lépnek fel, s ez kihatásában akár a személyiség széteséséhez vezethet." - írja. ${ }^{451}$ Baddeley úgyszintén rámutat, hogy a felejtés nyilvánvaló haszna, hogy enyhíteni tudja az érzelmi kínokat. Jobban emlékszünk a kellemes, mint a kellemetlen dolgokra. „Egyes megfigyelések szerint maga az emberi emlékezet hajlamos így viselkedni, aminek persze megvannak a hátulütői is, hiszen ez a múlttal kapcsolatos torzítások veszélyével jár."452

Fogalmazhatunk úgy, hogy az emlékezet a mindenki számára elérhető, (mozgó)képes rögzítési lehetőségek által finomodott és tágult - e jelenség azonban napjainkból nézve még beláthatatlan hatást gyakorol az identitás kialakításának lehetőségeire. Jelen alfejezet a lehetséges következmények kapcsán kíván felmutatni néhány vizsgálandó problémakört.

\section{IV.2.1. A technikai képek hatása az önképre}

A magyar nyelvben külön szóalakunk van az emlékezetre és az emlékezésre. A német nyelv úgyszintén különbséget tesz az emlékezet mint a képek archívuma (Gedächtnis) és az emlékezés mint aktivitás, a képek felidézése (Erinnerung) között. Hans Belting szerint ez a különbségtétel arra utal, hogy egyrészt birtoklunk (emlék)képeket, másrészt létrehozzuk őket. Mindkét esetben az emberi test, illetve annak egy része, az agy szolgál olyan élő médiumként, amely észleli, elképzeli a képeket, vagy emlékezik rájuk. És ez lehetővé teszi a képzeletünk számára, hogy cenzúrázza vagy megváltoztassa őket. ${ }^{453}$ Ezen lehetőségek az emlékek külső tárolása esetében nem adottak.

Ha a vizuális média emlékekre gyakorolt hatását kívánjuk elemezni, akkor meg kell vizsgálnunk, mi történik, ha a tudatban rögzült, dinamikus természetű mentális képek egy részét „kiváltjuk” állandó tulajdonságokkal bíró, soha nem változó, fix, külső hordozóra mentett képekkel. Nos, azok kétségtelenül objektívebben őrzik az emlékeket, mint a tudatunk, ugyanakkor a velük való belső munka jóval akadályozottabb.

A személy önképe, szelf-identitása egy önmagáról kialakított mentális képhalmaz, amellyel az illető kísérletet tesz önmaga objektív szemlélésére. Beletartozik az önmagáról

\footnotetext{
${ }^{451}$ Z. Karvalics László: Emlékezet és személyiség. In: Liget, 2012/7. 35.

${ }^{452}$ Baddeley, Alan: Az emberi emlékezet. Osiris Kiadó, Budapest, 2005. 22.

${ }^{453}$ Belting, Hans: Kép, médium, test: az ikonológia új megközelítésben. (Ford.: Matuska Ágnes) In: Apertúra, 2008. ősz http://uj.apertura.hu/2008/osz/belting/ (letöltés: 2017.09.25.)
} 
szerzett tudás és önmaga megértésének összegzése, melynek komponensei közé tartoznak kulturális, etnikai/nemzeti, vallási és nemi identitásai. Az önkép kialakítása kisgyermekkorban kezdődik, és a kamaszkor táján válik többé-kevésbé stabillá, noha bizonyos mértékig egész életünkön át formálódik. Kialakításához hozzájárulnak többek között a cselekedeteinkhez, a külső és belső adottságainkhoz kapcsolódó környezeti visszajelzések, az események megéléséhez kapcsolódó reakciók - illetve az ezekről megőrzött emlékek.

A fizikai kép - hasonlóan a többi embertől érkező véleményhez, dicsérethez, szidalmazáshoz, pozitív vagy negatív kritikához - egy visszajelzés az egyén számára. Annál is inkább, mert mint láttuk, hajlamosak vagyunk azt gondolni, hogy a fénykép és a videó objektív képet mutat rólunk. Ha azonban egy személyről egymás után több fotós, több különféle géppel készít felvételt, a „hü” képmásokat összehasonlítva megállapíthatjuk, hogy mindegyik egy kicsit másmilyennek mutatja alanyát. Ettől függetlenül nem mellékes senkinek sem, hogy az osztályképen, a tablón, az évkönyvben vagy éppen az esküvői képein hogyan fest. Ezeken általában jól - hiszen az egyén számít a fotózásra, készül rá, a fotós pedig ideális esetben igyekszik megtalálni a legelőnyösebb profilját. Így e képeknél még érvényesül az emlékezet valamiféle irányítása. A pillanatképekről ez már nem mondható el.

Egy rosszul vagy rosszkor elkapott pillanatban készült, a szereplőt előnytelenül ábrázoló, csúnyának, esendőnek, ellenszenvesnek mutató, vagy éppen egy beállított, retusált, a valóságot átrendező, túlidealizált állapotot rögzítő fotó kihat az egyén önmagáról alkotott véleményére. De míg a természetes emlékezet jótékonyan törölhet, korrigálhat, kiegyensúlyozhat egy ilyen mentális képet, addig a technikai kép mindig ugyanolyan marad, újra és újra emlékeztetve a szereplőjét egy pillanatnyi állapotra, amely talán nem is volt jellemző vagy jellegzetes. E pillanatkép mégis egy hosszabb időszak emblematikus képévé válhat, felülírva a természetes emlékezetet. Talán ezért állítja Roland Barthes azt, hogy a fotó lényegét tekintve sohasem emlék, és még le is béníthatja az emlékezést, emlékhiánnyá változtatva azt. „A fotográfia erőszakos, nem azért, mert sokszor erőszak a témája, hanem azért, mert minden egyes alkalommal erőszakkal tolakszik szemünkbe, semmit sem tud letagadni, nem tud átalakítani." ${ }^{454}$ Persze, mondhatjuk, hogy az ember sosem volt ura az emlékeinek, mert mindig voltak olyan külső erők, amelyek hatottak az elraktározott emlékképeinkre: a szüleink például gyakran mesélnek történeteket a kisgyermekkorunkról, és egy idő után már magunk sem tudjuk pontosan, hogy valódi emlékeket tárolunk-e az adott napról, vagy csak azért tudjuk, hogy mi történt, mert meséltek róla nekünk, és a mese alapján elképzeltük a történteket.

\footnotetext{
${ }^{454}$ Barthes, Roland: Világoskamra. Európa Könyvkiadó, Budapest, 1985., 104.
} 
Napjaink emberének azonban nem csak a szavakkal mesélt történetek manipuláló hatásával kell megküzdenie. A szelekciót még annyira sem tudja saját belső késztetéseinek megfelelően véghezvinni, mint déd- vagy ükszülei generációja, hiszen - ahogy láttuk - egyéni életútjának nem csak a jelentős, hanem a kevésbé jelentős állomásai is dokumentáltatnak. Tehát amennyiben nem vitatjuk azt a tényt, hogy emlékezetünk jelentős mértékben formálja a szubjektív tudatunkat, akkor arra a következtetésre kell jutnunk, hogy önképünk a fotók és videók kiszolgáltatottjává vált. Kénytelenek vagyunk belátni, hogy amikor a szülők arról döntenek, hogy gyermekeiket melyik pillanatban, milyen szituációban kapják lencsevégre, vagy amikor arról határoznak, hogy mely képeket tegyék a lomtárba és melyeket a megőrzendő mappába, akkor utódaik szelf-identitását formálják. Teszik ezt anélkül, hogy tisztában lennének cselekedetük jelentőségével.

E folyamatban azonban érvényesülhet egy ezzel ellentétesen ható erő is: minél több fizikai-technikai képet gyártunk, annál inkább elaprózódik ezek hatása. Míg pár évtizeddel ezelőtt egy fiók mélyéről előkerült régi kép számtalan gondolatot indukált, addig a mostanában készült, bármikor hozzáférhető, óriási mennyiségben és jellemzően digitálisan tárolt képanyag áttekintésére kevesen veszik a fáradságot. A most felnövekvő generációnak nem igazán lesznek emblematikusnak nevezhető, korszakokat jelképező fotói.

Az emlék kifejezést a magyar nyelvben két értelemben is használhatjuk. Érthetjük alatta az emlékül, emlékbe, emlékként kapott, készített, megőrzött emléktárgyat. Ilyen értelemben a legjellemzőbb emlék(tárgy) a fotó, még akkor is, ha nem kerül hordozóanyagra, csupán digitális jelhalmazként létezik. Az így értelmezett emlékek inflációja nyilvánvaló: minél több van belölük, minél könnyebben hozzáférhetők, annál inkább elértéktelenednek, inflálódnak.

A másik értelmezés szerint az emlék az emlékezési folyamat során kódolt, tárolt és előhívott információk egy-egy összefüggő csoportja. Az első értelemben vett emlék(tárgy) megkönnyíti, ugyanakkor irányítottá teszi az előhívás folyamatát, illetve azt az illúziót keltheti, hogy előhívás történik, holott csak nyugtázzuk, hogy a látott fénykép vagy mozgóképsor a múltunk egy szelete. A természetes emlékezet aktív, a mesterséges pedig passzív. Minél több ilyen, nyugtázandó képsort látunk, annál kevésbé ásunk mélyre, hogy természetes emlékezetünkben megkeressük a hozzájuk kapcsolódó információtartalmakat, hiszen azokat erőfeszítés nélkül kiolvashatjuk az információgazdag képi dokumentációból is. De mivel az elvben bármikor rendelkezésünkre áll, nem érezzük szükségét a természetes emlékezet mozgásban tartásának és frissítésének. Ilyen értelemben az emléktárgyak inflációja a tudatos emlékidéző folyamatokat korlátozva végső soron a felejtéshez járul hozzá. 
Az életét végigdokumentáló ember talán kevesebbet tud önnön individuális múltjáról, mint elődei, akik csak a természetes emlékezetükre támaszkodhattak. S amit tud, az sem feltétlenül adekvát, hiszen tudása torzításoknak, manipulációnak van kitéve. Önmagában még emiatt sem kellene aggódnunk, hiszen a természetes emlékezet is szelektív illetve szubjektív. Meg kell azonban különböztetnünk a belső, pszichés folyamatok vezérelte szelekciót és konstrukciót a külső, technikai eszközök befolyása alatti szelekciótól és konstrukciótól. Elfogadva, hogy az emlékezetünk befolyásolja az önmagunkról kialakított képünket, önazonosságunkat, meg kell állapítanunk, hogy a kettő minden bizonnyal eltérő szelf-identitást hoz létre. A technikai képek sokaságából összeálló technikai emlékezet tehát más emberré formál bennünket, mint amilyenné természetes emlékezetünk kizárólagos hatóterében válnánk. $\mathrm{S}$ ha ez a technikai emlékezet - bármikori hozzáférhetősége miatt - jelentőségét veszíti és be sem tölti funkcióját, akkor számolnunk kell azzal a változástényezővel is, amelyet a ritkább emlékidézés okoz: múltunk leképezett pillanatai állandóan körülöttünk vannak, ám súlytalanná válva szinte semmiféle hatást nem gyakorolnak ránk.

\section{IV.2.2. A megőrzött pillanatok (anti)kultusza}

Ha napjaink emberét megkérdeznék arról, hogy jártában-keltében miért készít fotókat és videókat a legkülönfélébb dolgokról, zömmel két féle válasz születne. Függetlenül attól, hogy a II. fejezetben láthattuk, hogy a fotók egyre inkább egy kiterjesztett jelennek szólnak, a többség bizonyára mégis azt válaszolná, hogy „emléknek”: később majd vissza szeretne emlékezni arra, hogy mit élt át a megörökített pillanatban. A megkérdezettek másik része pedig bevallaná, hogy fel szeretné tenni valamelyik közösségi portálra, hogy megossza másokkal is az élményt, amit ő átélt, vagy demonstráljon számukra egy létállapotot.

Lehetséges, hogy az első válasszal az individuum becsapja önmagát, öncsalást követ el, csapdába kerül - és az emlékek megőrzése helyett azok inflálódásához, kioltásához járul hozzá. A fotók és filmek már nem töltik be az „emlék” funkciót, mert nem használjuk őket sem az átélt pillanatok felidézésére, és jóformán semmi másra sem az elkészülésük utáni időkben.

Családi fotográfiáink kapcsán egyszerre figyelhető meg egy kultusz és egy antikultusz. Egyfelől egy teljes iparág épült köréjük: az elkészítésükhöz szükséges technikai eszközökön túl különféle formájú és méretü kereteket vásárolhatunk hozzájuk, különféle papírokra, tárgyakra nyomtathatjuk öket, fotókönyveket és posztereket készíthetünk belölük, albumokba tehetjük őket. Másfelől azt láthatjuk, hogy az emberek többsége nem tart rendet emlékei között. A képek 
ott kavarognak számítógépes eszközei, telefonjai, közösségi oldalai különböző mappáiban, szelekció nélkül, míg egy szándékos vagy véletlen törlés következtében oda nem vesznek.

A világ az 1839. augusztus 19-i dátumot tekinti a fényképészet megszületésének. ${ }^{455} \mathrm{Az}$ e dátumot követő bő másfél évszázadban a fényképek leginkább az emberélet jelentős állomásain készültek: keresztelők, születésnapok, esküvők, stb. alkalmával. A fénykép készülése ekkor még fontos eseménynek számított a szereplök életében: nem mindennapi történéseket, hanem fontos aktusokat, az emberi élet mérföldköveit ábrázolták. Napjaink embere azonban már szinte minden nap lát valami olyat, amiről úgy gondolja, hogy emlékké akarja tenni: vissza szeretne emlékezni arra, hogy mi történt a nyaraláson, milyen volt a gyermeke vagy a háziállata egy adott időszakban, hogy nézett ki a lakása, milyen volt a kertje, hogy állt rajta az új ruha, kik voltak a munkatársai, milyen érdekes vagy mókás volt a megörökített pillanat. Míg régen egy esküvői kép nagy becsben tartott emlék volt - talán az egyetlen, a nagyszülökröl - addig a mai, több órás lakodalmi mozgóképfelvételt talán soha többé nem nézi vissza senki, miután a DVD-lemez tokjában a polcra került az utazásokról és születésnapokról készült videók mellé.

Az ipari emlékgyártás során olyan mérhetetlen mennyiségü digitális kép kerül az ember számítógépére vagy egyéb tárhelyére, amennyit később fizikai képtelenség számontartani. A jelenséget már mintegy fél évszázaddal ezelőtt igen találóan fogalmazta meg Lewis Mumford A gép mítoszában: „Önmagunk és valóságos élményeink, valóságos környezetünk között ott hömpölyög a képek egyre emelkedő áradata, amelyet a legkülönfélébb források - a fényképezőgép és a nyomtatás, a film és a televízió - táplálnak. Régente a kép, a képi szimbólum ritka dolog volt, elég ritka ahhoz, hogy elmélyült koncentrációra tarthasson igényt. Mára azonban a valóságos élmény lett a ritka, és a kép mindennapossá vált.”456

Érdekes, egyben kissé bizarr jelenség az, amikor mindennapi használati tárgyakra párnahuzatra, bögrére, kulcstartóra, pólóra, kötényre, telefontokra, táskára - nyomtattatjuk a szeretteinket ábrázoló képeket. Ezzel megpróbáljuk őket kultikussá tenni, hiszen az ideológia továbbra is az emlékőrzést, emlékelöhívást határozza meg célként - még akkor is, ha a képen látható személy egyébként része a mindennapjainknak. De ha ez nincs is így, és a tárgyak hivatottak azt az érzést kelteni, hogy távoli hozzátartozóink ott vannak velünk, akkor is inkább antikultuszba torkollik a próbálkozás. Mivel e tárgyak a leghétköznapibb funkciókat töltik be, és szinte állandóan körülöttünk vannak, ottlétüket már természetesnek vesszük, és nem

\footnotetext{
${ }^{455}$ A francia Tudományos- és Képzőművészeti Akadémia együttes ülésén ekkor mutatták be hihetetlen nemzetközi érdeklődés közepette a dagerrotípia készítésének eljárását.

${ }^{456}$ Mumford, Lewis: A gép mítosza. Budapest, Európa Könyvkiadó, 1986. 242-243.
} 
késztetnek bennünket semmiféle mentális folyamatra. A nagyszülök az unokák képét, a szerelmesek egymás képét a puszta dekoráció szintjére degradálják. Annak fényében pedig különösen szánalmasnak hatnak e próbálkozások, hogy a zsebünkben lapuló telefont elővéve egyébként is bármikor hozzáférhetővé válnak a szeretteinket ábrázoló képek.

A csak digitális jelként létező képek értéke is erőteljesen megkérdőjeleződött. Az emberek többsége nem szelektál az egy-egy alkalommal készített fotók között, nem törli ki az elrontottakat, egy-egy témáról egymástól alig különböző, redundáns beállításokat is megőriz. Ezek vagy halmozódnak a számítógépén, telefonján, felhőtárhelyén, közösségi oldalán, vagy időnként törli őket - ha nem is feltétlenül szándékosan, hanem egy-egy technikai hiba, vírus miatt, vagy egyszerüen csak azért, mert készüléket vált, és arra nem másolja át a régi képeit. Ebből jól látható, hogy azok igazán nagy értéket nem képviselnek a számára.

A jelenben tehát egymás mellett él egy különös emlék-kultusz és az emlékekkel kapcsolatos gondatlanság. Ennek oka bizonyára abban keresendő, hogy az individuális múltunk megörzése és elöhívása túlságosan is kézenfekvő. Evidens, hogy egész életünkben fényképeznek bennünket. A mai ember tisztában van vele, hogy minden lépését kamerák követik, különféle platformokon (pl. közösségi oldalakon vagy az ismerösök albumaiban) tünnek fel az őt ábrázoló képek, így nem ébred fel benne az a félelem, hogy emlékeit elveszítheti. Ráadásul emlékgyártás ügyében már nem csak a szülőkre, rokonokra, barátokra vagy a hivatásos fotósokra hagyatkozhatunk, de önportrék révén is bővíthetjük mesterséges emlékezetünket. A selfie készítési folyamatához általában az is hozzá tartozik, hogy az elkészült képet ugyanazzal a technikai eszközzel (jellemzően okostelefonnal) feljavítják. A szolgáltatók egymás után dobják piacra azokat az alkalmazásokat, melyek segítségével pár kattintás árán eltüntethetők a pattanások és árnyékok, csillogóbbá tehető a szem - így napi szinten megejthetők mindazon beavatkozások, amelyeket korábban csak a tabló- és esküvői fotókon eszközöltek a hivatásos retusőrök. Az egyén olyanná formálhatja önnön képét, amilyenné szeretné - és amikor évekkel később visszanézi azt, ismét gyönyörködhet a végeredményben, rég megfeledkezve arról, hogyan érte azt el.

Amikor a XX. század végén, XXI. század elején született emberek távoznak majd ebből a világból, az utódokra vélhetően egy-egy kaotikus képhalmazt hagynak majd önmagukról, amelyből nehezen fog kirajzolódni egy hiteles portré. Az unoka ma még becsben tartja a nagyszülők néhány fotóját, de vajon milyen értéket fog képviselni az utánunk maradó digitális adathalom? Becsben lehet-e majd tartani? Veszik-e majd a fáradságot az utódok, hogy kiválasszák belőle a legjellemzőbbeket? Nem zárhatjuk ki azt az opciót, hogy hiába gyártjuk iszonyatos mennyiségben az „emlékeket”, azok még kevesebb eséllyel fognak nyomként 
megmaradni utánunk, mint a fotográfia hajnalán készültek. Mi magunk sem fogjuk - még a leghevenyebb nosztalgikus hangulatban sem - valamennyit végignézni, az utánunk maradók pedig talán mégannyira sem, hisz minden felmenői ágról örökölnek egy-egy ilyen halmazt.

Az ember tehát becsapja önmagát, amikor azt mondja, meg szeretné örökiteni a szép pillanatokat. Hiába adott a lehetőség, a megörökítés valószínüleg csupán illúzió, amely a képek inflációjával elenyészik. Emlékeink tehát egyfelől manipulációt szenvednek el, másfelől inflálódnak a vizuális média hatóterében.

\section{IV.3. A kollektív emlékezés narratíváját meghatározó technikai kép}

„Az emlékezet nem csak elöfeltétele, hanem terméke is a médiának. A média arra szólit fel bennünket, hogy a közös múlttal is egyesüljünk, ne csak a személyessel.",457

Roger Silverstone

Az írásbeliség felfedezése előtt egy közösség számára a szájról szájra terjedő történetek, az ezekből összeálló mitológia, és a hozzájuk kapcsolódó rítusok jelentették az emlékek megörzésének lehetőségét. Emlékek alatt ekkor még kizárólagosan a közösség emlékeit kell értenünk, egyrészt azért, mert az individuális lét eleve sokkal kisebb hangsúlyt kapott, így igény sem volt az egyes ember emlékeinek szervezett számontartására, másrészt azért, mert rögzítés híján azok sírba szálltak az egyénnel, vagy legkésőbb a közvetlen leszármazottjaival. A mitológiába kizárólag azok az emlékek épülhettek be, amelyek nem csupán egy-egy személy vagy család életében voltak meghatározóak, hanem a közösség sorsára nézve bizonyultak formáló erejünek.

Amikor a történelem folyamán az ember külső megőrzési lehetőségeket keresett az emlékeknek, a biztosított hordozókra kezdetben szintén csak a közösség emlékeit kívánta átvinni. A megfestett, lerajzolt, kőbe vésett ember nem mint egyén, hanem mint a közösség, az állam, a birodalom történetének meghatározó alakja örökíttetik meg. Az egyén - amely nem mint valamiféle közösségformáló hős vagy uralkodó, hanem mint individuum fontos - még a reneszánszban sem egy kimerevített időpillanatban jelenik meg a külső hordozón, hanem időbeli általánosítást, pózt, némi idealizálást kap. Nem az a cél, hogy az utókor az illető életének egy mozzanatát megismerje, hanem az, hogy minél átfogóbb, teljesebb képet kapjon, minél több információt, adatot leolvashasson és megtudhasson felmenőjéről. Ez még a korai

\footnotetext{
${ }^{457}$ Silverstone, Roger: Miért van szükség a média tanulmányozására? Akadémiai kiadó, Budapest, 2008. 150.
} 
fotográfiákra is jellemző: a szereplők úgy helyezkednek el a képen, hogy pozíciójukból, a körülöttük elrendezett tárgyakból és a háttér megválasztásából következtetni lehessen egymáshoz füződő viszonyukra, társadalmi helyzetükre, rangjukra, foglalkozásukra, érdemeikre, eredményeikre, szokásaikra, kedvteléseikre - ezáltal a közösségben, családtörténetben betöltött szerepükre. Így e képek nem csupán, sőt, nem elsősorban az egyén, hanem a család vagy a közösség külső emlékezeteként szolgáltak. Azt, hogy valakiről fénykép készülhessen, valami módon ki kellett érdemelni - családot, egzisztenciát kellett teremteni, amelyet érdemes megmutatni az utódoknak, vagy legalább valamilyen fontos, sorsfordító eseményre volt szükség hozzá, mint például az elsőáldozás, a berukkolás, vagy házasságkötés. Az információsürítés, az utókor számára szándékosan kódolt üzenet csak a pillanatképek, elterjedésével veszít jelentőségéből, és a selfie-k térhódításával szűnik meg - amelyek már individuális emléknek tekinthetők.

Az egyén emlékgyártási buzgalma közben mi történik a közösség emlékeivel? A közösségi emlékezetet hogyan változtatta meg a vizuális média, és e változások hogyan függnek össze a közösségi identitással? Az individuális emlékezet képi kitettsége után vegyük górcső alá az emlékezetnek ezt a dimenzióját is, közösségi emlékezet alatt nem feltétlenül valamiféle kollektív szubjektumot értve, inkább azokra az esetekre gondolva, amikor több egyén éli át ugyanazt az eseményt, és rögzíti azt az emlékezetében, vagy adja ezt tovább a közösség tagjainak.

\section{IV.3.1. A mediatizált technikai kép mint történeti forrás}

„A közösségeknek [...] van történelmük - bizonyos értelemben a múltjukból állnak -, ezért egy igazi közösség az emlékezet közössége, mely nem felejti el a múltját." ${ }^{458}$ - fogalmazza meg Bellah szerzőtársaival. Z. Karvalics László pedig így ír: „Az emlékezetnek van egy, kizárólag az egyének társas viszonyaiból levezethető része is: ahol az emlékezet tárgya nem a saját, hanem különböző méretü, erejü és életkorú közösség története". ${ }^{459}$ A közösségekre nézve a közös múlt formáló erejü lehet, ennélfogva az emlékezet identitással való összefüggése nyilvánvaló. Az identitáselméletekben bekövetkezett narratív fordulat óta az identitásra nem

\footnotetext{
${ }^{458}$ Bellah, R.N., Madsen, R., Sullivan, W., Swidler, A., Tipton, S. M.: Habits of the Heart: Individualism and Commitment in American Life. Berkeley: University of California Press, 1985. 153. Idézi: Jeffrey K. Olick és Joyce Robbins: A társadalmi emlékezet tanulmányozása: a "kollektív emlékezettől" a mnemonikus gyakorlat történeti szociológiai vizsgálatáig. (Ford.: Kulcsár Dalma) Replika 37, 1999. 30.

${ }^{459}$ Z. Karvalics László: Emlékezet és személyiség. Liget, 2012/7.
} 
mint tulajdonságra, hanem inkább mint gyakorlatok, cselekvés-sorok, narratív építési folyamatok összességére tekintünk, amelyek valamiképpen a múlt narratíváira vonatkoznak. ${ }^{460}$

A kollektív tudat fogalmát kutató Durkheim tanítványa, Maurice Halbwachs fejtette ki a kollektiv emlékezet fogalmát, ${ }^{461}$ mintegy társadalmi jelenségként tekintve az emlékezetre. Ö csak az észlelést tekinti egyéninek, az emlékezés szerinte mindenképp a csoport által meghatározott. Számára a kollektív emlékezet a tudás belső, tagok közötti megoszlása, az egyéni emlékezet pedig a kollektív emlékek sajátos kapcsolódásának színtere. A kollektív emlékezet fogalma alatt tehát nem feltétlenül valamiféle kollektív szubjektumot kell értenünk, a kollektív szó itt inkább arra utal, hogy több egyén éli át ugyanazt az eseményt, és rögzíti azt az emlékezetében, egyfajta élményközösségbe kerülve velük. Ezt a képet árnyalja tovább Jan Assman, aki a társadalmi emlékezettel új szemszögből foglalkozik, megkülönböztetve mimetikus, tárgyi, kommunikatív és kulturális emlékezetet. Rámutat arra, hogy létezik emlékezet-formálás, a kulturális emlékezet tudatos irányítás és ellenőrzés alatt állhat, illetve megállapítja, hogy az emlékezet kommunikációban él és marad fönn. ${ }^{462}$

Mint a III.1. fejezetben láttuk, korunk emberének kommunikációja a verbálisról egyre nagyobb mértékben tevődik át egy vizuális síkra. A technikai kép azonban rendelkezik egy olyan tulajdonsággal, hogy (bizonyos mértékig) maradandó, ezáltal nem csak a kommunikáció pillanatában van hatással az emlékezet és az identitás narratíváinak szövődésére, de később is „segít” kiigazítani a bennünk élő képet, a „valóságnak” megfelelően. A vizuális média kivívta a maga előkelő helyét az emlékek megőrzésében, folyamatosan kínálkozik az emlékek felidézésében való segítségnyújtásra, ezáltal meghatározó részt követel a közösségi történeti narratíva kialakításából. Ám a megőrzött látványt konzerválva nemigen teszi lehetővé, hogy a természetes emlékezet valamilyen okból újrakonstruálja, megváltoztassa e narratíva szövetét.

Az individuális emlékezet kapcsán már rámutattunk az emlékezet szelektív voltára, valamint arra a tényre, hogy sohasem lehet maradéktalanul objektív. Különféle külső és belső szempontoktól, ösztönöktől vezérelve formáljuk, alkalmasint újra konstruáljuk vagy szelektáljuk emlékeinket. Az emlékek ily módon történő alakulása, változása, metamorfózisa végső soron: feldolgozása - nem csak az egyénre, de a közösségre is jellemző. Ha olyan eseményekre tekintünk vissza, amelyek még a fényképezés elterjedése elött történtek, azt látjuk, hogy a történetírók próbálják azokat valamilyen módon belesimítani az adott nép

\footnotetext{
${ }^{460}$ V.ö.: Bodor Péter (szerk.): Emlékezés, identitás, diszkurzus. L'Harmattan, 2015.

${ }^{461}$ Lásd a szerző következő müveit: Les cadres sociaux de la mémorie (1925), La topographie légendaire des évangiles en terre sainte. Étude de mémoire collective (1941), La mémoire collective (1950)

${ }^{462}$ Assman, Jan: A kulturális emlékezet. Írás, emlékezés és politikai identitás a korai magaskultúrákban. Atlantisz, Budapest (é.n.) 35-38.
} 
identitástudatába. Szándékosan és önkéntelenül is manipulátnak - ez jól látszik abból, hogy ugyanazt az eseményt mennyire másképp tálalták a különböző népek vagy közösségek krónikásai. Nem véletlenül vált közhellyé: a történelmet a győztesek írják - vagy legalábbis az általuk megírt történelem meghatározóbb az utódok ismereteire nézvést. Ha pedig a történetírás előtti időkre tekintünk vissza, e „manipuláció” még inkább tetten érhető: a mondák, mítoszok a szimbólumok erejével teszik feldolgozhatóvá, érthetővé, vagy akár tanulságossá az eseményeket, alkalmasint a lényegtelen részletek elhagyásával, vagy egyes mozzanatok megváltoztatásával. A manipuláció - a hozzá tapadt negatív felhang miatt - itt persze nem jó kifejezés, hiszen természetes és ősi mechanizmus a múlt közösség érdekeinek megfelelő formába öntése, amely nem valamiféle ördögi terv alapján működik, hanem vélhetően ösztönösen, az idő megtisztító munkáját felhasználva.

Érdekességként ide kívánkoznak Nacsinák Gergely András meglátásai, aki a görög mitológia felől közelít: az emlékezet nem emberi teljesítmény, hanem egy istennő, Mnémoszüné ajándéka. „Ahol az Emlékezés Istennője nincs jelen, ott a kultúra az emberi emlékezet prédája lesz, vagyis a történetírásnak, az első széllel változó pillanatnyi szempontoknak, kisstílü érdekeknek és a hatalom propagandájának kiszolgáltatott. (...) A mítosz itt is szimbólumokban, ősképekben mutatja magát, így hozva létre a látáshoz és a megértéshez szükséges distanciát; azt a távlatot, amelyet a kronológiában és adatokban elmerülő történeti tudat nem ismer. " ${ }^{~ 463}$ A mítosz ilyen értelemben tehát magasabb rendü, mint a történetírás. Annyi azonban biztos, hogy mind a mitológiának, mind pedig a történetírásnak megvan a maga - sok mindenben eltérő - funkciója az identitás meghatározásának folyamatában. „Amíg azonban a mítoszban az identitást az istenek és hősök másságával kapcsolatban építik fel, addig a történetírásban az identitás folyamatát a múltnak a jelenhez viszonyított másságának játszmájában határozzák meg.” - írja Paolo Desideri. ${ }^{464}$

Ám mind a mítoszok keletkezési folyamatára, mind a korai történetírásra igaz a feljebb taglalt két jellemző: a szelekció, illetve az objektivitás nem maradéktalan volta. E kettő nélkül ugyanis lehetetlenné válna a lélektani feldolgozó munka - és talán a szilárd identitás kialakítása is. A fotó és a mozgókép megjelenése alapjaiban változtatta meg a múltról való gondolkodást. A külső hordozóra rögzített kép (elvben) tökéletesen objektív, hiszen a (látható, tapasztalható) valóságot dokumentálja. A szelekció is egyre nehezebben valósítható meg, ahogy egyre többen

\footnotetext{
${ }^{463}$ Nacsinák Gergely András: Az emlékezés atlasza. Liget, 2015.09.01. http://ligetmuhely.com/nacsinak-gergelyandras-az-emlekezes-atlasza/ (letöltés: 2016.12.7.)

${ }^{464}$ Desideri, Paolo: Scrivere gli eventi storici. In: I Greci. Storia, cultura, arte, societa. I Noi e i Greci. Torino, 1996. 955-1013. Idézi: Cusumano, Nicola: Mnémoszüné-Lészmoszüné: emlékezés és feledés, mitosz és történelem. Egyed Péter fordítása. In: Korunk, 1997. augusztus.
} 
és többen készítenek egyre több és több képet, képsort, és őrzik azokat különböző helyeken, különböző fennhatóságok alatt.

„Abban a pillanatban, ahogy az Emlékezet elválasztódik a mítosztól, a történelmi időnek, a múlt időnek a funkciója lesz: elveszíti eredeti és isteni képességét a lét és igazság megvilágítására" - írja Nicola Cusumano. ${ }^{465}$ Ha állítása már a történetírásra is igaz (azaz a történetírás által kutatott alétheia leértékelt igazság, amely a doxából fejlik ki) akkor kijelentése fokozottan érvényes lehet a fotók és mozgóképsorok által kirajzolt igazságra. Érdemes odatenni e kijelentés mellé Roland Barthes fotográfiával kapcsolatos gondolatmenetét is, aki felveti, hogy él bennünk valami leküzdhetetlen ellenállás, ami miatt nem tudunk hinni a múltban, a történelemben, ha az nem mítosz formájában jelentkezik. Szerinte „,a Fotográfia először törte meg ezt az ellenállást: a múlt a fotó megjelenésétől kezdve ugyanolyan bizonyosság, mint a jelen; amit a papíron látunk, az ugyanolyan biztos, mint amit megérintünk."466 Ugyanakkor Barthes nyomatékosítja azt is, hogy a fotográfia nem idézi fel a múltat, nem az idő és a távolság által lerombolt dolgok rekonstruálásával hat ránk, hanem azzal, hogy tanúsítja: valóban volt, létezett az, amit látok. ${ }^{467}$ És a látott kép a mítosszal ellentétben nem formálódhat, így a fotóval elenyészik a tragikum, a fotó kizár mindenfajta megtisztítást, katarzist. Egy közösség önmagáról való gondolkodását tehát nyilvánvalóan egészen más irányba tereli a nagy pillanatait ábrázoló fényképek megléte, hozzáférhetősége ahhoz képest, mint ha csak a mítoszokra támaszkodna. Az előzőekben már megvizsgáltuk, hogy mi történik az egyén emlékeivel a technikai képek erőterében, megállapítva, hogy énképünk a fotók és videók kiszolgáltatottjává válhat. Mindez részben igaz a közösségek vagy épp a nemzetek önképére is. Ahhoz, hogy ez az önkép pozitív legyen, ahhoz, hogy a közösségi önbizalom erősödjön (és ezáltal a közösség produktívvá váljon) nem elég - a szelekció és a megszépítés eszközeivel is élve megfogalmazni, értelmezni a vele történteket, mert a technikai képek tartalma felülírhatja, összezavarhatja az így kialakított identitás-narratívát. Vajon a nehezebben megszülető identitás hitelesebb és reálisabb lesz-e?

\footnotetext{
${ }^{465}$ Cusumano, Nicola: Mnémoszüné-Lészmoszüné: emlékezés és feledés, mitosz és történelem. (Ford.: Egyed Péter) In: Korunk, 1997. augusztus. http://korunk.org/?q=node/6124 (letöltés: 2016.12.7.)

${ }^{466}$ Barthes, Roland: Világoskamra. Európa Könyvkiadó, Budapest, 1985., 99.

467 u.o. 94.
} 


\title{
IV.3.2. Történelmi távlaton belül rekedve?
}

\author{
„S aki kihull, megérdemelte, \\ Az ocsut az Idö nem szánja, \\ Aszott nemzetek, hült világok, \\ Tört életek miazmás vágya \\ Halálra-valók s nem kár értük." 468 \\ Ady Endre: Az Idö rostájában
}

A XX.-XXI. századi eseményekkel kapcsolatban gyakran halljuk azt a kijelentést, hogy megfelelö történelmi távlat hiányában bonyolult a megítélésük. Kérdés azonban, hogy meglesze, meglehet-e valaha a megfelelö történelmi távlat, ha szinte feldolgozhatatlan mennyiségü, az összképet túlságosan is árnyaló forrás áll rendelkezésre.

Érzékelhető egy olyan tendencia, amely azt mutatja, hogy a média hatóterében a közösségi emlékezet atomizálódik: egyre inkább individuális emlékek tömege rajzolja ki a történelmet, szemben a mitológia vagy akár a történetírás jóval egységesebb, kerekebb világával. Az újmédia világában az egyéni történetek felértékelődnek, vagy legalábbis a felértékelődés illúzióját keltik, hiszen eljuthatnak a nyilvánosság elé. A folyamat visszamenőleg is hat: egyre több olyan internetes portál, vagy közösségi oldalon működő csoport van, amely a XX. század történelmi eseményei kapcsán fogadja és publikálja az egyéni történeteket. (A történettudományban előtérbe került az oral history mint kutatási módszer.) Az unokák leírják vagy videófelvételre rögzítik és beküldik azt, amit a nagyszüleik meséltek nekik. Más portálok pedig a fényképeket gyüjtik: például régi, családi albumokban pihenő fotográfiákat a világháborúkat megjárt katonákról. Ily módon apró mozaikokból áll össze a történelem valamely fejezete. Hans Belting szerint azóta, hogy megnőtt az érdeklődés a nem verbális kommunikáció iránt, ,,a társadalomtudományok is egyre nagyobb mértékben fordulnak a történelem képi médiumai felé, holott korábban csak a szövegeket vették komolyan."469

Napjaink időszakáról viszont nem kell majd az utódoknak összeszedni a mozaikkockákat, hiszen a mai ember személyesen juttatja el történeteit a nyilvánosság szféráiba. Blogol és vlogol, történeteket oszt meg - és egyre kevésbé írásban, egyre inkább képekben vagy mozgóképen. Ezek már nem mozaikkockák, hiszen a mozaik egyik jellemzője, hogy a kis kockák közötti réseket más anyag tölti ki, és a kockák akár többféle módon összepasszíthatók. A korunkról létrejövő narratíva inkább a puzzle-hoz hasonlít: a darabkák

\footnotetext{
${ }^{468}$ Az Idő rostájában című vers Ady Endre Ki látott engem? címü, 1914-es kötetében jelent meg. Ady Endre müvei. Összes versek I., Szépirodalmi könyvkiadó, Budapest, 1972. 647. old. 2. versszak

${ }^{469}$ Belting, Hans: A müvészettörténet vége. Atlantisz Könyvkiadó, Budapest, 2006. 234.
} 
tökéletesen egymásba illeszthetők, a kép folytonos, rések nincsenek. A dokumentálás szinte maradéktalan. De talán ezt a hasonlatot is el kell vetnünk, hisz egyrészt ebben a narratívában átfedések is bőven akadnak majd, másrészt a kép háromdimenziós lesz, hiszen minden több perspektívából megörökítve marad fenn. A kihívást inkább a végtelen számú forrás áttekintése okozza majd. Láttuk, hogy ha egy-egy közelmúltbeli esemény - például egy vihar, egy baleset vagy egy terrortámadás - képanyagát szeretnénk áttekinteni, akkor a hivatásos (sajtó)fotósok illetve televíziós operatőrök munkái mellett a kamerás telefonjukat éppen előkapó érintettek, jelenlévők, szemlélődők által készített felvételekre szintúgy támaszkodhatunk. Így egy-egy eseményt számos, egyéni szemszögből rögzített felvétel rajzol ki, amelyeket egymástól távol, különböző családok számítógépein őriznek - ugyanakkor általában egy közös gyűjtőhelyre: az éppen favorizált közösségi oldalra is felkerülnek.

Így aztán a modern tömegmédia minden vizuális platformján: a televízióban, az interneten, a videomegosztó csatornákon és közösségi oldalakon elérhetővé válnak a civilek által készített, csak idézőjelesen ,„privát” álló- és mozgóképes tartalmak. Ugyanakkor persze folyamatosan növekszik azoknak a technikai képeknek a száma is, amelyeket hivatásos szakemberek készítenek eleve a közösség számára, amelyek a közösség emlékeit hivatottak őrizni. Ezek rögzítése, közzététele és archiválása a különféle sajtóorgánumok, leginkább pedig a közszolgálati média feladata. A szélesebb tömegeket értintő eseményeket tévéstábok és fotósok tömkelege dokumentálja.

Flusser szerint a technikai képek olyan felületek, amelyek duzzasztóként müködnek. Minden történetet magukba szívnak, végtelenül reprodukálhatóak, így a társadalom örökké forgó emlékezetét alkotják: „Semmi sem állhat ellen a technikai képek eme szívóerejének nincs olyan müvészi, tudományos vagy politikai tevékenység, amely ne erre irányulna, nincs olyan mindennapi esemény, amely ne akarna fotón, filmen, videofilmen megöröklődni." ${ }^{\prime 70}$ Flusser hozzáteszi: ahogyan e képek univerzuma kirajzolódik, az idők teljességeként mutatkozik meg, amelyben minden cselekedet és szenvedés szakadatlanul kering.

Roger Silverstone pedig felveti, hogy talán nincs igazuk azoknak, akik szerint a posztmodern korból hiányzik a történelem. Szerinte inkább túl sok van belőle! „Minden narratívánk nagy narratíva. Minden figyelmet követel, mindet folyamatos elemzésnek vetik alá." A média és az örökségipar folyamatosan felkínálja a múltról alkotott saját verzióit, múltunk láthatóvá tett változatait. ${ }^{471}$

\footnotetext{
${ }^{470}$ Flusser, Vilém: A fotográfia filozófiája. Tartóshullám - Belvedere - ELTE BTK, Budapest, 1990. 18.

${ }^{471}$ Silverstone, Roger: Miért van szükség a média tanulmányozására? Akadémiai kiadó, Budapest, 2008. 149.
} 
Minél közelebb érünk a jelenhez, annál részletgazdagabb a képi dokumentáció. Gondoljunk például a Világkereskedelmi Központ ikertornyainak 2001-es összeomlására: akkoriban már számos magánszemély, turista közlekedett kamerával, így több szögből sikerült rögzíteni az eseményt. ${ }^{472}$ De még ennek az eseménynek a dokumentáltsága is elenyésző a 2010 utáni történések, például az Európa nagyvárosaiban lezajlott terrortámadásokéhoz képest. Az előkapott telefonok egyedi nézőpontokat és egyedi történetszálakat örökítenek meg.

E pontos dokumentáltságnak és árnyaltságnak természetesen lehet jó oldala is: talán pont ezáltal tudunk hitelesebb képet alkotni a múlt eseményeiről. Közben viszont aggodalomra adhat okot az, hogy e folyamat a közösség tagjai (és azok utódai) számára megnehezíti az események áttekintését, értelmezését, letisztulását, beépítését a közösségi identitásba. Mi lehet jobb a közösség számára: ha fekete-fehérre tisztul a kép, vagy ha mindörökre (talán átláthatatlanul) árnyalatgazdag marad?

És vajon mennyi fog fennmaradni ezekből a képsorokból? Hacsak valamilyen csapás következtében össze nem omlik a digitális civilizáció, akkor a múlt minden részlete velünk marad. Korunk egyik nagy kérdése tehát az, hogy kijátszható-e az idő rostája? Vagy ez csupán illúzió, és a legsokrétübb dokumentálás, a leggondosabb archiválás ellenére sem marad majd fenn több információ e korról, mint a korábbiakról? És ha sikerül mindent konzerválni, az utókor mit tud majd kezdeni egy túlárnyalt képpel, a tört életek miazmás vágyával, amely Ady versében még kihull az idő rostáján?

\section{IV.3.3. Képeknek kiszolgáltatott közösségi identitás?}

Természetesen nem szabad elvetnünk annak a lehetőségét, hogy a technikai képek ilyen meghatározó jelenléte akár előbbre is viheti az emberiséget, élesítve az önkritikát, segítve a valósággal való szembenézést. Ehhez azonban feltételeznünk kellene, hogy a fotó és a videó a valóságot mutatja meg, de mint az számtalanszor bebizonyosodott: ugyanarról a dologról más és más hangulatú, mást hangsúlyozó, másmilyen érzelmeket tükröző álló- és mozgóképsorokat készítenek a fényképészek és operatőrök. És természetesen lehet csalni a kompozícióval, a képkivágással, a gépállással, ${ }^{473}$ mozgókép esetén a snittek sorrendjével, dinamikájával, stb., az

\footnotetext{
${ }^{472}$ A World Trade Center kifejezésre rákeresve a youtube videomegosztó portál több mint 1300000 találatot dob ki. A 2001.09.11-én reggel, a repülőgépek becsapódása során/után készült amatör és profi képsorokat füzi össze például a NetworkLive filmje (https://www.youtube.com/watch?v=wNNTcHq5Tzk letöltés: 2017.07.30.) amelyet több, mint 36 millióan láttak. A látszólag igen gazdag forrásanyag, a bőséges dokumentáció dacára a mai napig nem tisztázott, pontosan mi is történt akkor.

${ }^{473}$ Ha például alsó gépállásból, közismertebb néven békaperspektívából mutatunk egy személyt, az zsarnokinak, felső gépállásból, vagyis madártávlatból pedig kicsinek, esendőnek tűnhet.
} 
utómunkáról nem is beszélve. A kérdés tehát korántsem egyszerü: a számtalan technikai kép gátolja az emlékezet manipulációját, vagy épp táptalajt képez számára?

Tomsics Emőke a történeti muzeológia és a sajtódokumentáció viszonya kapcsán írja, hogy a sajtóképek által megjelenített múlt és a különböző valóság-értelmezések számos kutatási kérdést felvetnek; a sajtófotó kultúrtörténeti megközelítéseiböl kiderülhet, hogy a fotográfiának van egy hagyományos közösség-integráló funkciója a társadalomban, ez pedig ráirányíthatja a figyelmet a kollektív emlékezet konstruálódásának folyamataira. ${ }^{474} \mathrm{~A}$ média képei tehát nyilvánvalóan nem csak egyéni, de közösségi szinten is hatnak az emlékezetre, és azon keresztül nem csak a szelf-identitásra, hanem az egyén kulturális vagy nemzeti identitásösszetevőire is, illetve a közösségi identitásra. E téren is egyre fontosabb szerep jut a nemprofesszionális, privát képeknek, amelyek előtt már szabad az út a nyilvánosság tere felé.

Amennyiben egy olyan történelmi eseményt szeretnénk felidézni, amelynek idejében már készültek fotók vagy mozgóképfelvételek, akkor a médiaarchívumokban fogunk keresgélni valamilyen meghatározott célt magunk elé tüzve. A modern kor történeti forrásai kétségkívül ezek a tárhelyek, amelyek számos kutatónak adnak munkát most és a jövőben. De vajon mitől függ, hogy mit találnak keresgélés közben? A közösségi lét fordulópontjain készült képek, képsorok mennyire adják vissza az eseményt a maga teljességében? Mitől függ például az, hogy ha beírjuk az internetes keresőbe, hogy „csernobili atomkatasztrófa” vagy épp „párizsi terrortámadás”, akkor mely képeket dobja ki a program az első találatok között? Söt, a kérdések sora már ott kezdődik, hogy mely események képi lenyomatai kerülnek be a nagy nézőtáborral rendelkező médiumok felületeire ${ }^{475}$, illetve később az archívumokba? Hiszen amiről nem szólt a média, az szinte olyan, mint ha meg sem történt volna. Másodsorban, nagyon sok minden múlik a fotós illetve az operatőr munkáján. Mit érez fontosnak kiragadni az eseményből? Az eseménynek helyet adó tér mely részletét örökíti meg és melyik pillanatban? Milyen kompozícióban, milyen képi eszközökkel láttatja azt? Harmadrészt: az elkészült fotókból vagy snittekből melyek lesznek azok, amelyek végül igazán nagy publicitást nyernek? E kérdésekre nyilvánvalóan nem létezik egyszerü válasz, hiszen az okok mindig a szituációtól, a pillanatnyi érdekektől függnek. Azt is mondhatjuk: a véletlen, illetve az internetfelhasználók elöre megjósolhatatlan döntései egyre nagyobb mértékben alakítják e sokszereplös folyamatokat.

\footnotetext{
${ }^{474}$ Tomsics Emöke: A történeti muzeológia felöl. Recenzió Bán András: A vizuális antropológia felé c. könyvéhez. In: Budapesti Könyvszemle, 2009. 333-339.

${ }^{475} \mathrm{Az}$ internetes oldalak legnépszerübb 0,01\%-a bonyolítja az összes forgalom 50\%-át. Lásd: Sandvig, Christian: Az internet szerkezeti problémái a kultúrpolitika nézópontjából. In: Halácsy Péter, Vályi Gábor, Barry Wellman (szerk.): Hatalom a mobiltömegek kezében. Typotex, 2007. 66.
} 
Hans Belting úgy véli, a médiumok szimbolikus technikákat használnak, és ezek segítségével közvetítik, illetve vésik be a képeket a kollektív emlékezetbe. Szerinte a képek politikája $^{476}$ a medialitásuktól függ, mivel a medialitás legtöbbször intézmények által szabályozott, és egy politikai hatalom céljait szolgálja. Még akkor is - teszi hozzá Belting - ha ez a hatalom megbújuk egy látszólag anonim közvetítés mögött. A képek politikájának szüksége van egy médiumra ahhoz, hogy a mentális képet fizikai képpé tegye. ${ }^{477}$

Nem csoda, ha napjainkban a szociológusok figyelmét is egyre inkább felkelti a (mediatizált) kép mint forrás és mint társadalmi folyamatokat indukáló erő. A képekre a tudás jellegzetes vizuális formáiként tekintenek, a fényképek önmagukban létező alkotás-volta itt nem érdekes, sokkal inkább társadalmi produktumaiként tekintenek rájuk, bízva abban, hogy az általuk közvetített ismeretek hozzájárulhatnak a társadalmi kommunikáció szociokulturális környezetének megismeréséhez. Howard S. Becker amerikai szociológus szerint a kép olyan kulturális objektum, amely a használattól függően a kontextusában nyeri el jelentését. ${ }^{478}$ Ilyen értelemben fontos megvizsgálni azt, hogy a kép (elsősorban sajtófotó, mozgóképes tudósítás) milyen körülmények között készült, ki volt a fotós, a megrendelö, a célközönség.

Érdekes, és ezen a ponton mindenképp említésre érdemes jelenség az, amikor az egyén arra emlékszik, hogy a médiából milyen módon, milyen körülmények között értesült egy-egy eseményről. Az ún. vakuemlékezet, vagy villanófény emlékezet fogalma Roger Brown és James Kulik kutatók 1977-ben lefektetett elméletéhez köthetö. ${ }^{479}$ Megközelítésükben ez olyan körülményekre vonatkozó emlékezet, amelyben rögzítjük a nagyon meglepő, fontos vagy érzelmileg megrázó eseményeket. Kutatásaikat a kollektív lét média által hírül adott eseményei köré építették, mint amilyen például a Kennedy-gyilkosság, a Reagan elleni merénylet vagy éppen a Challenger-katasztrófa. Úgy találták, hogy az erős, meglepődést okozó és következménnyel járó publikus eseményekből igen pontos, fényképszerü lenyomatot hagyó emlékek maradnak vissza, amelyekbe minden részlet belesürüsödik. Ulric Neisser ugyanakkor arra hívja fel a figyelmet, hogy ilyenkor nem is a kiváltó hír részleteit őrizzük meg fotografikus

\footnotetext{
${ }^{476}$ Eredetileg W.J.T. Mitchell vezette be ezt a kifejezést, azt kutatva, hogy milyen érzelmi-ideológiai és politikai aktus fejthető fel a képek mögött.

${ }^{477}$ Belting, Hans: Image, Medium, Body: A New Approach to Iconology, Critical Inquiry. Volume 31., Winter, 2005, 302-319.

${ }^{478}$ Becker, Howard S.: Visual Sociology, Documentary Photography, and Photojournalism: It's (Almost) All a Matter of Context. In: Prosser, Jon, ed.: Image-based Research. A Sourcebook for Qualitative Researchers. London: Falmer Press., 1998., 84-95.

${ }^{479}$ Brown, Roger - Kulik, James: Flashbulb memory. In: Neisser, Ulric (editor): Memory observed. W.H. Freeman \& Company, 1982.
} 
hüséggel, hanem olyan személyes részleteket, hogy hol voltunk, mit csináltunk, amikor meghallottuk a hírt. ${ }^{480}$

Ehhez a jelenséghez kapcsolható egy meglehetősen bizarr hazai példa is. Amikor Magyarország rendszerváltás utáni első, szabadon választott kormányának miniszterelnöke elhunyt, az ország lakosságának öt és tizenöt év közötti tagjai szinte valamennyien a televízió előtt ültek, hogy - mint minden vasárnap - megnézzék az akkori honi televíziózásban egyedülállónak számító Családi mozidélután a Disney-vel című műsort. Így aztán a '80-as évek elején születettek nagy része sajnos ma is a megszakított Kacsamesékre és Dagobert bácsira ${ }^{481}$ asszociál, amikor meghallja Antall József nevét. Ez az eset tehát jól példázza, hogyan tudja a média (szándéktalanul is) manipulálni a közösségi emlékezetet. (Ugyanakkor azt a nem tudatos belső igyekezetet is jelzi, ahogyan a tőlünk távoli, csak a médiából megtudott történéseket megpróbáljuk valamilyen módon személyessé transzformálni - talán azért, mert a korábbi évezredek tömegmédia nélküli világában az emberielme ahhoz szokott hozzá, hogy csak azok az események lehetnek meghatározóak, amelyeket személyesen élünk át, amelyek tapasztalhatóan kihatnak a sorsunkra.)

A szándékos manipulációra is rengeteg példát lehetne hozni. Roger Fenton vélhetően megrendezte a hadifotózás történetének legelső és leghíresebb fotóját, A halál árnyékának völgye címü, a krími háborúról impressziót adni hivatott képét. Robert Capa A milicista halála címü, világhíres képének elkészülési körülményei szintén vitatottak. Széles körben ismertek a sztálini időkben a fotókról leretusált szereplők esetei is. ${ }^{482}$ A filmhíradó története szintén számos dicstelen esetet hagyott ránk, elég az 1898-as spanyol-amerikai háború idején készült, Santiago-öbölbeli tengeri csatáról készített tudósításra gondolni, amelyet egy fürdökádban, hajómakettekkel forgattak, vagy éppen a hazai mütermekben készült második világháborús magyar haditudósításokra. A közelmúlt is bővelkedik hasonlókban, gondoljunk például Frei Tamás miniszterelnök-ölésre vállalkozó bérgyilkosára ${ }^{483}$ vagy arra a botrányra, amit a $\mathrm{CNN}$ néhány munkatársa kavart, amikor elismerték, hogy olykor bizonyítékok nélküli félinformációk, hazugságok is adásba kerülhetnek. A példákat hosszan lehetne sorolni, jelen munka azonban most nem ezek számbavételére vállalkozik.

\footnotetext{
${ }^{480}$ Neisser, Ulric \& Harsch, Nicole.: Phantom flashbulbs: False recollections of hearing the news about Challenger. In E. Winograd, U. Neisser (szerk.): Affect and accuracy in recall: Studies of 'flashbulb' memories. New York, NY US: Cambridge University Press, 1992. 9-31.

${ }^{481}$ A gyászzenével megszakított, 1993. december 12-i adás ma az egyik videomegosztó portálon látható: https://www.youtube.com/watch?v=wZQw-xuMCTc (letöltés: 2016.11.25.)

${ }^{482}$ Lásd King, David: Retusált történelem c. könyvét. PolgArt Könyvkiadó Kft., 2002

${ }^{483}$ Az állítólagos bérgyilkosról Juszt László derítette ki, hogy valójában statiszta. Frei később úgy nyilatkozott, hogy őt is félrevezették.
} 
A szándékos befolyásolás témakörébe tartozik, noha nem a hatalom, hanem a befogadók egyes csoportjai által kifejtett tevékenységként a képrombolás aktusa, amely a múlt megváltoztatására vagy legalábbis kitörlésére tett kísérlet. Ide vág az a gondolat, amelyet Belting a szovjet és iraki emlékmüvek lerombolása kapcsán vet fel, amelyek a nyilvános bosszú cáltábláivá váltak egy elnyomó rendszer után. Szerinte a hivatalos képek, melyeknek célja a kollektív tudatba való bevésődés, elősegítették a képrombolásnak ${ }^{484}$ mint a szimbolikus felszabadulás gyakorlatának megjelenését. Ilyen típusú képrombolás még ma is létezik, noha kevésbé nyilvánvaló módon: ilyen, amikor a képeket egyszerüen kivonják a forgalomból a sajtóban vagy a televízióban, illetve törlik, töröltetik az internetről azzal a céllal, hogy megszüntessék a láthatóságukat.

A kollektív emlékezet folyamatosan ki volt és van téve manipulációnak, hiszen számos külső tényezőtől függ, hogy a történelemkönyvekbe mi és milyen tálalásban kerül bele. A történelem számtalanszor bizonyította, hogy nagyobb közösségeken, generációkon, nemzeteken is lehet „agymosást" végezni, el lehet érni, hogy embertömegek teljesen más színekben lássák a múltat vagy a múlt egy-egy szeletét. A média demokratizálódása ${ }^{485}$ látszólag gátolja az ilyen irányú tevékenységet, hiszen a kapuőrök hatalma - számuk növekedésével csökkent. A számtalan kisebb és nagyobb orgánumból és a közösségi média felületeiből összeálló modern médiát nem lehet elhallgattatni, valamennyi szerzőjét nem lehet megvásárolni. A visszatartani kívánt információ valahol úgyis nyilvánosságra kerül, és a legvadabb elméleteknek, legradikálisabb nézeteknek is akad fóruma. Ez azonban nem jelenti azt, hogy nem kell tartanunk a manipulációtól, amelyhez a vizuális média - mint láttuk - kiváló eszközt kínál.

\footnotetext{
${ }^{484}$ Ez a felszabadító célú képrombolás nem egyenlő azzal a képek iránti megvetésből táplálkozó képrombolással, amelyet Baudrillard emleget Simulacres et Simulation című, 1981-es írásában. Az ő felfogásában a képrombolást az váltja ki, hogy kép szimulálni próbálja a tiszta és érthető eszmét, illetve kiszorítja azt. A tét abban az esetben a képek „gyilkos hatalma”, ami a valódit, a kép modelljét fenyegeti. Ld.: Baudrillard, Jean: A szimulákrum elsöbbsége. In: Kiss Attila, Kovács Sándor, Odorics Ferenc (szerk.): Testes könyv I., Dekon könyvek, Ictus / JATE Irodalomelmélet Csoport, Szeged, 1996. 163-164.

${ }^{485}$ A média demokratizálódása alatt az újmédia korszakához, a közösségi médiához köthető folyamatokat szokás érteni, melyek révén már nem egy szük réteg küld információkat a széles tömegeknek (ld. tömegkommunikáció), hanem bárki részt vehet az információk szerkesztésében, egy interaktív, sokirányú és nonlineáris folyamat keretében.
} 


\section{A fejezet összegzése: Egy vizuális kor identitásproblémái}

Az emlékezet és a személyiség fogalma nem választható szét. Emlékeinkből építjük fel önazonosságunkat, a cselekedeteinket és a reakcióinkat pedig meghatározzák azon az információk, amelyeket emlékként tárolunk. Érthető tehát, hogy az emlékek eltűnésétől vagy megváltozásától való félelem - amely részben azonos a nyomhagyás nélküli elmúlástól való rettegéssel - szinte egyidős az emberiséggel. E félelem motiválta az embereket arra, hogy „mankókat” keressenek az emlékek megőrzéséhez és átadásához. Ebből kifolyólag a kommunikáció története az emberi emlékezet történeteként is felfogható: az emlékek megóvásának, felidézhetőségének és továbbadásának folyamatában meghatározónak bizonyultak a kommunikációtörténet mérföldkövei.

A beszéd kialakulása, az írás elterjedése, a könyvnyomtatás felfedezése, a fotográfia és a mozgókép eljárásainak feltalálása hatással volt az emberi memória használatára és kihasználására: úgy tünik, a végesnek vagy sérülékenynek érzett emberi emlékezőtehetség helyett egyre inkább a külső, tárgyi hordozókra támaszkodunk. E folyamatot koronázza meg a vizualitás jegyében fogant digitális forradalom. Napjainkra a technikai képek váltak a leginkább preferált emlékhordozókká.

Míg a belső emlékezet tárhelye véges, addig a külső, mesterséges- vagy más terminussal technikai emlékezet kapacitása viszont gyakorlatilag végtelen - és e végtelenség arra csábít bennünket, hogy egyfajta emlék(tárgy)termelésbe fogjunk. Ugyanakkor az emlékezet túl sok külső történő megtámogatása nem feltétlenül azt a célt szolgálja, hogy az emlékek tovább fennmaradjanak, sőt. Szembe kell néznünk azzal a lehetőséggel, hogy a magunk után hagyott hatalmas digitális-képi adathalmaz által az emlékek elértéktelenedéséhez, inflálódásához járulunk hozzá. Az emlékőrzés e módszerváltásával emlékeink tartalma, hangulata, minősége - és mindezzel együtt az önképünk, identitásunk konstruálásának folyamata is - változásokon megy át. Máshová kerülnek a hangsúlyok, élményeink felidézése manipulálttá és egyoldalúvá válhat. A természetes emlékezetre jellemző szelekciós funkció illetve a szubjektivitás részleges kiiktatása ugyancsak beláthatatlan következményekkel jár.

Lewis Mumford már félszáz évvel ezelőtt rámutatott: „,bár a fényképészet természetét illetően szelektív müvészet, terjedése és fejlődése, különösképpen a film feltalálásától fogva, inkább az ellenkező irányba halad: a tartós képek annyira megszaporodtak, mint korábban sohasem, és a túlzott bőség egyszerủen kikezdte a gondos értékelés és válogatás régi 
hagyományát." 486 Pedig éppen az értékelés és a válogatás az, ami elősegíti, hogy ne ragadjunk benne a jelenben, hanem képesek legyünk megítélni a múltat, levonni a tanulságokat, és elgondolni azt, hogy milyenné szeretnénk formálni a jövőt.

Annyi bizonyos, hogy nem könnyítjük meg az utókor dolgát, nem lesz egyszerü az utánunk maradó, elsősorban vizuális információhalmazból kihámozni a lényeget, „képet alkotni” egy olyan korról, amely képmilliárdok képezte töredékekből áll össze. Hogyan is várhatnánk el ezt az utódoktól, amikor mi magunk sem vagyunk rá képesek?

Persze meg is fordíthatjuk a problémafelvetést: attól még, hogy mi magunk képtelenek vagyunk saját identitásunk körvonalazására és egy letisztult emlékhalmaz átörökítésére, miért lenne biztos, hogy az utókor sem fogja tudni hová tenni ezt a korszakot? Egyrész bőséges dokumentálás ide vagy oda, történhetnek olyan események, amelyek mindezt megsemmisítik, amelyek eltörlik a Föld színéről az elektromosságon alapuló digitális civilizációt. Másrészt ha fenn is maradnak fotóink és mozgóképsoraink, illetve az azok dekódolására alkalmas eszközök - nem zárható ki, hogy az utánunk jövőket ez koránt sem érdekli majd annyira, mint ahogy bennünket foglalkoztatnak a letünt korok. Nem zárható ki az sem, hogy a történetírás és a történetfotózás után ismét egy mitologikus kor jön, amely számára a történeti forrás nem tabu, és amely lesöpri az asztalról a zavaró részleteket.

Megállapíthattuk tehát, hogy a közösségi emlékezet egyfelől egy meghatározottságnak és kényszernek, másfelől manipulációnak van kitéve. Ugyanakkor atomizálódik, apró darabokra hasad: egyre inkább individuális emlékek tömegéből tevődik össze, melyek olykor egymással ellentétes üzenetet hordoznak, fokozva a zürzavart. Korunk embere tehát kijátssza „az idő rostáját”, megakadályozva, hogy abból „kihulljon az ocsu” - ám ezzel gátat vet annak is, hogy a fennmaradt tartalomból kirajzolódjon valamiféle tanulság.

„Képzelet, képesség, képtelenség - eljátszhatnánk a szavakkal s eljuthatnánk az énképhez, melyet a képdömping által elszegényített képzeletünk képtelen keretek közé rendezni. Legfőbb képességünk a rend - de lehet-e még rendet teremteni e képekkel elárasztott, gyermeteg kultúrában?”487 - teszi fel a kérdést S. Nagy Katalin, aki életmüve számos pontján figyelmeztet arra, hogy a képek áradata legsajátosabb megnyilvánulásunkat: a fantáziánkat szorítja keretek közé, illetve sorvasztja el. Napjainkra az emlékőrzés funkcióját mind egyéni, mind közösségi szinten a fotók és videók vették át, és az emlékek felidézése is ezeken alapul. A képzelőerő tehát itt, a múltidézés folyamatában is háttérbe szorul, igazolva $\mathrm{S}$. Nagy aggodalmait. Ennek egyik következménye az, hogy lehetetlenné, de legalábbis korlátozottá

\footnotetext{
${ }^{486}$ Mumford, Lewis: A gép mitosza. Budapest, Európa Könyvkiadó, 1986. 241.

${ }^{487}$ S. Nagy Katalin: A látvány, amelyben élünk. Műegyetem Kiadó, Budapest, 1993. 9.
} 
válik a folyamatba való beavatkozás. Mindez megnehezíti az emlékek szintetizálását, szelektálását, feldolgozását.

Gondolhatnánk, hogy a precíz képi dokumentáció miatt az egyének mind individuumként, mind a közösségek tagjaiként hitelesebben, árnyaltabban, jobban meg tudnak ítélni egy-egy jelentős eseményt, ám többnyire mégsem ez történik, hanem ennek ellenkezője: képtelenné válnak az erővonalak felfedezésére, a summázásra és a továbblépésre. A képek akadályozzák a véleményalkotáshoz szükséges távlat létrejöttét. Így persze akadályozottabb a „történelemhamisítás” és a múlt aktuális érdekeknek megfelelő újrakonstruálása is - ám ez egyúttal azt is jelenti, hogy az egyének és a közösségek soha nem tehetik le (történelmi) terheiket, nem koptathatják le bélyegeiket, nem kezdhetnek tiszta lapot.

Tekintetbe véve, hogy a képek áradata egyelöre nem apad, hanem duzzad, nem nehéz elképzelni, hogy rövidesen eljön az az idő, amikor fojtogatva érezzük majd magunkat a képek fogságában, vagy állandó rettegésben élünk, hogy mikor kerül elő egy rosszkor és rossz helyen, vagy félreérthető szituációban készült, még csak nem is feltétlenül hiteles felvétel. Hibáinkat nem engedhetjük el többé, hiszen azok nem csak emlékeinkben, de a külső hordozókon is tovább élnek majd. Közösségi szinten pedig a történelem terhei még meghatározóbbakká válnak: generációk sora már nem csak a ráolvasott szavak súlya alatt görnyed, de a legtöbb információt befogadni képes érzékszerve, a szeme által is kényszerítve lesz elődei kétes tetteinek szemlélésére és az azok miatti vezeklésre. Ezen a ponton ismét a szabadság kérdésköréhez érkezünk meg, amelynek kiharcolása talán egy újfajta motivációktól vezérelt képrombolásban ölt majd testet. De a másik alternatíva sem sokkal szívmelengetőbb: a fent vázolt folyamatok fásultságba is torkollhatnak, amennyiben annyira hozzászokunk a múlt körülöttünk lebegő árnyaihoz, hogy már semmiféle hatást nem gyakorolnak ránk, immunissá válunk irántuk. Ez a közöny viszont szükségszerüen egy olyan világot hoz létre, ahol tetteknek nincs súlya és következménye, nincs viszonyítási alap, példa, mérce. 


\section{Helyünk a képek között - esélylatolgatások}

„Mindenütt az eredetihez meglepöen hasonlitó univerzumban élünk, melyben a dolgok önnön forgatókönyvüknek megfelelöen kettözödnek meg. De a duplum, a hagyományban megszokottól eltéröen, nem jelenti haláluk fenyegetö közeledését. A dolgok már meg vannak tisztítva haláluktól, jobban, mint eleven réseiktöl; mosolygóbbak, autentikusabbak modelljüknél: olyanok, mint a funeral home-ok arcmásai. "488

Jean Baudrillard

Az előző fejezetekben már esett szó az ember és a kép viszonyának változásairól, valamint a képi fordulat hatásairól. Igyekeztem körvonalazni azt a jelenséget, amely az egyén vizuális portfólióalkotási lázában nyilvánul meg, és sorra venni azokat a motivációkat, amelyek e szükségletté vált cselekvés mögött felfejthetők, illetve azokat a tüneteket, amelyek kísérői ennek a jelenségnek. Az utolsó fejezetben szeretnék még néhány problémakört feltárni ehhez kapcsolódóan. Olyan problémaköröket érintek, amelyek kifutása még teljességgel bizonytalan, így célom csupán a kérdésfeltevés lehet. Szeretném megvizsgálni, hogy a következő időszak milyen fontos dilemmákat tartogathat még a mediatizált képiség, a táguló vizuális portfóliók kapcsán, illetve milyen következményei lehetnek az előző fejezetekben feltárt jelenségeknek? Hol találhatjuk meg a helyünket a képek áradatában, és miképpen viszonyulhatunk hozzájuk a jövőben?

A fotótechnika, a sokszorosíthatóság indukálta változásokat, a tömegmédia képközvetítésben betöltött szerepét és a képdömping generálta jelenségeket nem mindenki értékeli egyformán. Az optimista olvasat értelmében a kultúra termékeihez való hozzáférés nagy mértékben a képi reprodukció és a mozgókép által - kiszélesedik, a média és a kultúra demokratizálódása új lehetőségeket hoz magával, és egy új típusú befogadót eredményez. Az írott szó helyét átveszi a kép, amely legyőzi a nyelvi akadályokat, átível a nemzeteken és társadalmi rétegeken. A technikai kép nem ellenség, csupán meg kell tanulnunk bánni vele, ki kell tanulnunk a nyelvét, ki kell ismernünk, tudatos médiafogyasztókká kell válnunk, hogy kiküszöbölhessük a benne rejlő manipulációs lehetőségeket. Nem válságról, csupán változásról ${ }^{488}$ Baudrillard, Jean: A szimulákrum elsöbbsége. (Ford.: Gángó Gábor) In: Kiss Attila, Kovács Sándor, Odorics
Ferenc (szerk.): Testes könyv I., Dekon könyvek, Ictus / JATE Irodalomelmélet Csoport, Szeged, 1996. 169. 
van szó, az ember egyre inkább képekkel, képekben fejezi ki magát, leírt szavak helyett képekkel kommunikál.

Ezzel szemben a pesszimista megközelítés a technikai képektől való függést, a képkészítés és -publikálás jelenlegi mértékét és az ezzel járó vizuális inflációt válságtünetként interpretálja, az immanens esztétikai értékek hanyatlását valószínűsíti. Aggódik amiatt, ahogy a képek a média közvetítésével beleszólnak a mindennapjainkba, formálják nézeteinket, világlátásunkat, hangulatunkat, céljainkat, akaratunkat, emlékeinket, identitásunkat. Akaratlanul is szemünk elé és elménkbe tolakodnak, olyan mennyiségben, amelynek a feldolgozására és szelektálására már képtelenek vagyunk. Mintha csak ellenünk fordultak volna, holott mi magunk hozzuk őket létre, mi gyártjuk le és müködtetjük azokat a technikai eszközöket, amelyek segítenek nekünk a fotók és mozgóképek vég nélküli termelésében.

Az olyan meghatározó gondolatkörök, mint a Fukuyama-féle történelem végeelgondolás, a Kuhn-féle paradigmaváltások koncepciója, a Danto-féle művészet vége, a Belting-féle müvészettörténet vége és egyéb teóriák mind azt sejttették az ezredfordulóhoz közelítő emberrel, hogy valamiféle nagy átalakulás - válság vagy változás - részesei vagyunk. A hétköznapi beszédtémák között és a tudományos párbeszédben is gyakran szerepelnek az olyan kulcsszavak, mint identitásválság, értékválság, instabilitás. Mindemögött felsejlik egy paradoxon, hiszen közben úgyszintén nagy hangsúlyt kap a technikai és a gazdasági fejlődést, a demokrácia tökéletesedését éltető retorika, amely azt sugallja, mintha valamiféle csúcsponthoz érkeztünk volna, vagy attól legalábbis karnyújtásnyira lennénk. Csejtei Dezső felveti, hogy az emberiség a végleges megoldás meglelése helyett inkább a „világtörténelmi haladék” állapotába került. ${ }^{489}$ „Vajon a jelenlegi létmódra - annak minden sugallt stabilitása, tartóssága ellenére - nem valami eredendő, elemi ideiglenesség a jellemző?" ${ }^{490}$ - teszi fel a kérdést azon esélyek latolgatása közben, hogy jelen körülmények között milyen lehetőségek adódhatnak egy személyes és alanyi teljességgel jellemezhető minőségi életre.

Szabó Tibor egyenesen az instabilitás korának nevezi a jelenünket azzal a meggyőződéssel, hogy ,,a világot ontológiailag minden téren és minden szinten az instabilitás hatja át. Azt mondhatjuk tehát, hogy nincs is olyan szegmense a mai világnak, amelyben ne jelenne meg az instabilitás, a bizonytalanság vagy az egyensúlytalanság." ${ }^{491}$

\footnotetext{
${ }^{489}$ Csejtei Dezső: A minőségi élet esélyeiről. In: Csejtei Dezső: Írások Északról és Délszakról. Veszprémi Humán Tudományokért Intézet, Veszprém, 1999. 133.

${ }^{490}$ U.o. 134.

${ }^{491}$ Szabó Tibor: Az instabilitás kora. Belvedere Meridionale, Szeged, 2014. 13.
} 
A különböző elméletek nem egységesek azon kérdésekben, hogy az átalakulás tünetei valamilyen vég - a nyugati civilizáció vége vagy a teljes emberi civilizáció vége - felé mutatnak, vagy csupán egy új korszakba való átlendülést segítik-e elő. Az apokaliptikus víziókat olyan fogalmak használata jellemzi, mint a környezetszennyezés, a globális felmelegedés, a háborúk, a migráció vagy a (kettős kimenetelü, egyfelől a Föld túlnépesedésében megnyilvánuló, másfelől a nyugati berendezkedésű országok népességfogyásában megnyilvánuló) demográfiai válság, de gyakran kerül negatív konnotációba a média hatalmának növekedése és a virtualitás is, mint olyan eszközök, amelyek közelebb visznek a véghez. (Ezek közgondolkodásban való jelenlétét mi sem mutatja jobban, mint az apokaliptikus témájú filmek és sorozatok virágzása.)

Ám az is elképzelhető, hogy nincs kellő távlatunk annak megítélésére, hogy átlássuk, valóban különleges-e helyzetünk az emberiség történetében. Vannak, akik szerint a bizonytalanság érzése már sokszor rátelepedett az emberiségre, és a miénkkel analóg korszakokat is találhatunk. Umberto Eco a középkorral vonja párhuzamba korunkat. Azt állítja, hogy a két kor csaknem tökéletesen megegyezik abban, hogy „,́gy vagy úgy, hasonló didaktikus vágyálmoktól vezérelve és egy lelkiismeret diktálta paternalisztikus terv hasonló ideológiai álcázásaképpen vizualitással próbálja meg betömni azt a szakadékot, amely az értelmiségi kultúra és a népi kultúra között nyílt. Mindkét korban írott szövegekre támaszkodva, betűvető mentalitással érvelnek a választott elit képviselői, ám a lényeges tudnivalókat és az uralkodó ideológia alappilléreit ezután mindig a képek nyelvére fordítják le." ${ }^{492}$ Eco a középkori katedrálist hasonlítja a plakáthoz, a tévéképernyőhöz, a képregényhez. Ugyanezt észrevételezi Silverstone is, amikor arról ír, hogy a középkorban a világot a maga láthatóságában kellett olvasni - például az ólomüveg ablakok és szentélyek metaforáiban. ${ }^{493}$ A vizualitás felerősödése tehát korábban is megfigyelhető.

Egy bizonyos értelemben vett látáscentrikusság előtörését akár a nyomtatás feltalálásához is lehet kapcsolni, amely McLuhan szerint ${ }^{494}$ megerősítette a vizualitás elsőbbségét, amelyet később a távcső és a mikroszkóp felfedezése tovább erősített. De az ember és kép viszonyának változásait taglaló fejezetben láthattuk, hogy a XVII. századi holland festészettel vagy akár a barokk látványvilággal is rokonítható korunk. Így aztán nem tagadhatjuk egyértelműen azt, hogy talán valamiféle ciklikusság is kirajzolódhat a vizualitásra való hagyatkozás preferálásában, amelyet most, innen nézve még nem láthatunk át.

\footnotetext{
${ }^{492}$ Eco, Umberto: Az új középkor. In: Eco, Umberto: Az új középkor, Európa Kiadó, Budapest, 2008. 41.

${ }^{493}$ Silverstone, Roger: Miért van szükség a média tanulmányozására? Akadémiai kiadó, Budapest, 2008. 145.

${ }^{494}$ Lásd: McLuhan, Marshall: Understanding Media: The Extension of Man. McGraw-Hill, New York, 1964.
} 
Ugyanakkor az sem zárható ki, hogy valóban egy súlyos válság felé haladunk, amelyben a képek nem csupán átveszik az szavak szerepét, hanem közben kioltják egymás hatását, a kommunikációs folyamatokban zavar áll be, az visszaesik egy primitívebb szintre, és mindez egyfajta érdektelenség, szürkeség és kulturális ür felé tol bennünket. E dilemma eldöntésére jelen munka természetesen nem vállalkozhat, ám az eshetőségekre való felkészülés fontosságának hangsúlyozása mindenképpen szerepel a céljai között.

Lehetőségeink közé tartozik egy olyan magatartást felvenni, amely figyelmen kívül hagyja azt a tényt, hogy esetlegesen egy determinált vég felé haladunk, és mindent megtenni annak érdekében, hogy a negatív tendenciákon változtassunk - miközben az elkerülhetetlen változásoktól nem riadunk meg, hanem megpróbálunk felkészülni rájuk. E magatartásformának része, hogy mindent latba vetünk annak érdekében, hogy a képek természetét megismerjük, feltárjuk, kialakítsunk egy kritikus hozzáállást, média- és képtudatosságot, illetve valamiféle szabályrendszert illetve etikát és etikettet, amely a képekkel való kommunikáció folyamatában, a közösségi média színterein kapaszkodót nyújthat.

Mindez persze számos nehézségbe ütközhet, többek között abba, hogy egyáltalán felismerjük, melyek azok a tendenciák, amelyeknek megfordítására kell kísérletet tennünk, és melyek azok, amelyeket el kell fogadnunk - hiszen a technikai felfedezések generálta változásokat aligha lehet visszafordítani vagy semmissé tenni. Herbert Marcuse ugyan $A z$ egydimenziós ember címủ mủvének végén, az egydimenziós társadalom alternatíváinak esélyeit latolgatva A fölszabadulás katasztrófája címü fejezetben már 1964-ben eljátszik a gondolattal, hogy „ha semmi egyéb nem történne, mint, hogy eltünne az összes reklám, az összes indoktrináló információs és szórakoztató »média«, az egyénnek fejest kellene ugrania egy traumatikus ürbe, ahol esélye lenne a csodálkozásra, a gondolkodásra, önmaga (vagy inkább önnön negativitása), illetve társadalma megismerésére. Megfosztva hamis atyáitól, vezéreitől, barátaitól és képviselőitől, kénytelen lenne újra tanulni az ábécét. Ám ezután egészen másfajta szavakat és mondatokat képezhetne, s vágyai és aggodalmai is másmilyenek lehetnének." 495 Marcuse szerint egy ilyen szituáció elviselhetetlen lidércnyomás lenne a legtöbb ember számára. A média ugyanis támpontokat ad, még ha ezek hamisak is. Ráadásul a támpontokkal együtt a szórakoztatásuktól is megfosztaná az embereket egy ilyen helyzet, ami Marcuse szerint szintén elviselhetetlen lenne sokak számára. „Ha a televízió és a többi média beszüntetné müködését, ez képes lenne ily módon előidézni azt, amit a kapitalizmus belső ellentmondásai nem tudtak elérni - a rendszer szétesését. A represszív szükségletek fölkeltése már régóta a

\footnotetext{
${ }^{495}$ Marcuse, Herbert: Az egydimenziós ember. Fordította: Józsa Péter. Kossuth Kiadó, 1990. 270.
} 
társadalmilag szükséges munka alkotórészévé vált - »szükséges« abban az értelemben, hogy nélküle a fennálló termelési mód nem lenne fönntartható. Nem pszichológiai, nem is esztétikai kérdésekről van itt szó, hanem az uralom anyagi alapjairól."

Napjainkban ugyan már nem a televízió, hanem az internet nyújtja a legfőbb támpontokat, ám vélhetően ennek megvonása sem okozna kisebb megrázkódtatást - hiszen az internetfüggőség egyre több problémát okoz; 2013-ban ezen addikció prevalencia értéke a magyarországi középiskolások körében 7,4\% volt, de a távol-keleti országokban ez az érték több, mint a duplája is lehet. ${ }^{497}$ De ha a nem kóros magatartásformákat vesszük figyelembe, akkor is elmondható, hogy a nyugati civilizációban élő átlagember élete ezer szállal kötődik az internethez: nem csupán információit, tudását és tapasztalatait szerzi onnan, de ott vásárol, ott intézi a hivatalos ügyeit, tart kapcsolatot másokkal, szórakozik. (Teszi mindezt az állandóan cserélődő álló és mozgó képek közegében.) Egyre több bürokratikus és kereskedelmi rendszer épül a világhálóra, így nélküle valóban számos tekintetben válság következne be. Nem véletlen, hogy egyre több regény és film - pl. a 2006-os Jericho (rendezője: Jon Turteltaub) címü sorozat - témája épül arra, hogy valamilyen okból megszünik az elektromosság, összeomlik a média és ezáltal a teljes civilizáció. A digitális archiválás addig tekinthető biztonságosnak, léte addig fenntartható, amíg hozzáférhető az elektromos áram. Az internet révén kialakult csoportok (pl. a közösségi oldalakon) szintén csak addig képesek az egymás közötti kommunikációra, amíg az elektromosság biztosított. A számítógépes eszközökön tárolt adatok megfoghatatlanságuk folytán sérülékenynek tünnek, így sokakban felmerül a gondolat, hogy talán mindörökre elveszhetnek - ezt erösítik azok a tapasztalatok is, amikor valamilyen hiba folytán digitális adatokat veszítünk. Ez indukálja a filmekben is megjelenő víziókat, melyekből jól látható, hogy az embereket foglalkoztatja, milyen lenne visszatérni az elektronikus média térnyerése előtti időkbe. Ha előáll egy ilyen helyzet, akkor ahogy Marcuse fogalmazott: újra kell tanulnunk az ábécét. (Ezt ma érthetjük a szó szoros értelmében is, hiszen a Snapchat, az Instagram és a vlogok világában élő fiataloknak már ténylegesen egyre több kihívást okoz szavakkal, mondatokkal, írásjelekkel megfogalmazni egy levelet.)

Egyelöre azonban éppen az ellenkezője okoz problémát: képeink - nyomaink - a világhálón kitörölhetetlenné váltak, és általuk a múlt sokkal nagyobb teherként nehezedik ránk, mint valaha. Az internetes tartalmak végleges törlése igen nehéz feladat, hiszen sok esetben az archiváló oldalakon az információ továbbra is elérhető és kereshető marad, illetve az ún.

\footnotetext{
496 U.o.

497 Lásd: Galán Anita: Az internetfüggőség kialakulása és prevalenciája. A hazai és nemzetközi kutatási eredmények összefoglalása. Metszetek, 2014/1.
} 
Streisand-effektus ${ }^{498}$ is nehezítheti a törlést. A kamaszkori hibák vagy a már felnőtt korban elkövetett ballépések, netán a világhálón véghezvitt tréfák, méltatlan helyzetek képi nyomai életeket árnyékolhatnak be, karriereket törhetnek derékba, vagy épp családi boldogságot dúlhatnak fel. E helyzet sokaknak még új és szokatlan, a megfelelő elővigyázatosság nem alakult ki, és még nem nőttek fel azok a csecsemők, akik számonkérhetik szüleiken, hogy miért töltöttek fel róluk annyi, másokra nem tartozó fotót az internetre. Elképzelhető, hogy a képfeltöltésnek idővel kialakul a szabályrendszere, kifejlődik valamiféle óvatosság ezzel kapcsolatban, tudatosul, hogy a munkáltatók az állásinterjúk elött, a potenciális gazdasági partnerek az üzleti tárgyalások előtt, a potenciális magánéleti partnerek pedig a randevúk előtt áttekintik a világhálón hozzáférhető képeket. Bizakodásra adhat okot azonban az ún. „felejtéshez való jog” körüli, egyre szélesedő párbeszéd. Ennek eredménye, hogy 2018. május 25-től kötelező minden, az EU-n belül működő vállalat számára az új uniós általános adatvédelmi rendeletben ${ }^{499}$ elöírtak betartása, mely több lehetőséget biztosít a tartalmak töröltetésére.

De azzal az opcióval is számolhatunk, hogy a morális értékrend átalakulásával a társadalom megengedőbbé válik a ma még rosszallást vagy akár botrányt kiváltó képekkel szemben, egyszerüen azért, mert hozzászokunk ahhoz, hogy alig marad ember, akinek ne lennének nyilvánosan hozzáférhető, kétes megítélésű képei. Elképzelhető az is, hogy amiről ma még úgy gondoljuk, nem való a nyilvánosság elé, mert túl intim vagy bensőséges szituációt ábrázol, arról egy bizonyos idő elteltével változni fog a vélekedés, és megszokott lesz a nyilvánosság terében. Ám ahogy a IV. fejezetben már volt erről szó: e képek hatást gyakorolhatnak arra, hogy mit és hogyan örzünk meg magunkról és másokról az emlékezetünkben, így befolyásolják az önmagunkhoz és másokhoz való viszonyulásunkat is. A másik felmerülő, részben szociálpszichológiai reakciókra számot tartó problémakör pedig az a hatás, amit a magánszféra, az intimitás, a meghittség elveszítése és az állandó nyilvánosság előtti lét magában hordoz. Mindez nem csak az érzelmek és az emberi kapcsolatok elsekélyesedését, felületessé válását hozná magával, de - Csejtei Dezső fentebb említett gondolatmenetéből következően - felveti a személyesség mint a minőségi élet kritériumának veszélybe kerülését is. (Csejtei személyességen a személyes lét eredendő, egzisztenciális,

\footnotetext{
498 Így nevezik azt a jelenséget, amikor az interneten publikált információk eltávolítására tett kísérlet híre ellentétes hatást vált ki, és a cenzúrázni kívánt dolog még szélesebb körben ismertté válik. A jelenség Barbra Streisand színésznőről kapta a nevét, aki 2003-ban malibui házának fotóit próbálta eltávolíttatni az internetről, de miután a pernek híre ment, még többen lettek kíváncsiak a fotókra.

499 General Data Protection Regulation - GDPR. Magyarul olvasható: http://eur-lex.europa.eu/legalcontent/HU/TXT/HTML/?uri=CELEX:32016R0679\&from=HU (letöltés: 2018.03.31.)
} 
meditatív megtapasztalását érti egy életidegen, steril öntudat önazonosságának tételszerü kimondásával szemben.)

A további, felmerülő problémakörök sorát folytatva elérkezünk a relativizálódás kérdésköréhez. A II. fejezetben volt szó arról, hogy a digitális képek megjelenésével, a mitchelli posztfotografikus korszak kezdetével a befejezett kép fogalmának már csak a hagyományos eljárásokkal dolgozó fotósok, festők, grafikusok világában van létjogosultsága. Mindennapi fotóinkat illetően nem beszélhetünk kész képekről, csupán változatokról. A manipulációs eszköztár szélesre tárult, és bárki számára elérhető. A szépítő effektet már a fotó készítésének pillanatában rá lehet tenni a képre, így az ábrázoltnak nem kell szembenéznie azzal, milyen a valóságban. Külseje manipulálásának semmi sem szab határt, így előállhat az az eset, hogy a médiatérbeli életét (lásd II.3.3.) egy teljesen másmilyennek látszó testként éli. A valóság két síkján teljesen eltérő látványt nyújt. A filmkészítőket ez a téma is megihlette, lásd például a Hasonmás (2009, rendezte: Jonathan Mostow) vagy az Avatar (2009, rendezte: James Cameron) címü filmeket. Előbbi groteszk víziójában az emberek kényelmes ágyakon fekve irányítják saját hasonmásukat - ami sokszor éppen, hogy nem a hasonmásuk, hanem egy szebb és tökéletesebb, vagy akár teljesen más változatuk - aki helyettük végzi a mindennapi teendőket. Utóbbiban pedig egy tolószékben élő ember is újra futhat virtuális énje képében. E filmek nem csupán a virtualitás veszélyeire világítanak rá, de felvetik azt a kérdést is: marad-e hely számunkra a (digitális) képek között, vagy azok maszkokként végérvényesen eltakarhatják valódi énünket, személyes létünket? Tapasztalatainkat, élményeinket nem csupán képekből (lásd: II.3.3. fejezet) hanem bizonyos értelemben képek takarásában éljük. Másmilyen viszonyulásokat, reakciókat, visszajelzéseket tapasztalhatunk meg, amikor egy kép takarásában kommunikálunk, mint amilyeneket anélkül tapasztalnánk. Az eltérő tapasztalatok pedig más emberré formálhatnak bennünket. Ennek tudatosulása nem vezethet-e egy olyan állapothoz, melyben azt érezzük, hogy valamiféle elnyomás alatt vagyunk? És nem hozhat-e mindez magával egy olyan folyamatot, amely a képek mögül való kilépés, a képektől való szabadulás vágyához, és azon keresztül végső soron valami új képromboláshoz vezet?

Nyugtalanító képet fest az emberiségről Baudrillard, a már többször említett szimulákrum-elméletével (amely többek között a Wachowski-fivérek rendezésében megvalósuló, 1999-es Mátrix címü filmet is ihlette), melynek értelmében „búcsút int az egész metafizika" ${ }^{500}$, megkérdőjeleződik a kauzális szemlélet, hiszen már nem lehet tudni, mi minek a szimulációja. Míg Gombrich 1960-ban művészet és illúzió viszonyát vizsgálja, Baudrillard

\footnotetext{
${ }^{500}$ Baudrillard, Jean: A szimulákrum elsőbbsége. (Ford.: Gángó Gábor) In: Kiss Attila, Kovács Sándor, Odorics Ferenc (szerk.): Testes könyv I., Dekon könyvek, Ictus / JATE Irodalomelmélet Csoport, Szeged, 1996. 162.
} 
bő 20 évvel később kimondja: illúzió nem lehetséges többé, mert a reális sem lehetséges. A valóság kibontakozása ellehetetlenül. „Elöreláthatatlan, milyen terv, hatalom, stratégia, történet kelhet életre e bezáródott, semlegesített, használaton kívül helyezett, megérthetetlen, fel nem robbanó erőivel túltelített gigantikus rendszer mögött. Hacsak nem egy befelé irányuló explózió, egy berobbanás lehetősége, ahol minden energia elenyészik egy katasztrófa folyamatban"501 - rajzolja meg a nem túl biztató jövőt. Vajon van-e más kiút a szimulákrumból?

Ha nem történik valamiféle „öntudatra ébredés”, amely a fenti gondolatok folyományaként valamiféle szembefordulást jelentene a technikai képpel, és gátat vethet a baudrillard-i forgatókönyv elé, akkor adódik a kérdés: meddig fokozódhat a képek mennyiségi növekedése? Mennyi képet bírunk el? A II. fejezetben esett szó a vizuális infláció témaköréről. Ebből kiindulva képződhet a képeknek olyan feleslege, amelynek befogadására már képtelenek vagyunk, és ahol a képek az érzékelés peremére kerülve kioltják egymást. Ez azonban elsősorban azokra a szituációkra vonatkoztatható, amikor egy időben több kép pályázik a figyelmünkre - például egy nagyvárosi utcán sétálva. A képekkel való kommunikáció során azonban (lásd III. fejezet) más módon találkozunk a képekkel. Az üzenetküldő alkalmazások igénybevétele során a felhasználó egy-egy általa készített képet küld célzottan a másik felhasználónak. E kommunikáció során mindig egy kép van a szemünk előtt, noha az rövid időn belül cserélődhet egy újra. A verbális kommunikációban is problémát jelent, ha egyszerre hallunk több kimondott szót. Ha azonban egymás után halljuk őket, képesek vagyunk dekódolni az információt. Akkor tehát mégsem kell félnünk a mennyiségi növekedéstől? Hiszen attól sem félünk, hogy túl sok szót ejtünk ki a szánkon. (Noha voltak korok, amikor a kimondott szónak is nagyobb jelentőséget tulajdonítottak.) Eszünkbe juthat erről a régi mondás: a szó elszáll, az írás megmarad. Mindezt úgy is befejezhetnénk, hogy a kép megmarad. Ilyen értelemben tehát képekkel kommunikálni nagyobb felelősség, mint szavakkal. Úgy tünik azonban, hogy a szolgáltatók is észlelik ezt a problémát, és mindent megtesznek azért, hogy felhasználóikat mentesítsék e felelősség súlya alól - hiszen a felelősség és az élmény egymásra kioltó hatást gyakorló fogalmak. A 2018-ban 190 millió aktív felhasználóval rendelkező, Snapchat ${ }^{502}$ nevü képküldő alkalmazás lényege például az, hogy az elküldött képek néhány másodperc múlva törlődnek, így nem marad nyomuk. (Más kérdés, hogy az automatikus törlődés leginkább a szexuális tartalmú képek küldözgetése, az ún. sexting előtt nyitotta meg az utat.) Teljes biztonságot azonban ez sem garantál az ellen, hogy múltbéli képeink egyszer majd kísértetként

\footnotetext{
501 U.o. 191.

${ }^{502}$ Lásd: https://www.snapchat.com/
} 
térjenek vissza életünk egy másik időszakában - csupán az esélyét csökkenti. A címzett ugyanis megteheti például azt, hogy elmenthető képernyőképet készít róluk.

A digitális adathalmazként létező képekkel kapcsolatban tehát korunk gondolkodóinak alapvetően két végletes opcióval kell szembe néznie, és mindkettő számos kérdést felvet. Az egyik opció az, hogy a vizuális portfóliók tovább tágulnak, a másik pedig az, hogy elvesznek. Mindkettő egyaránt súlyos terheket ró az emberiségre. Az első esetben a múlt elfeledhetetlensége, a hibák korrigálhatatlansága, az „idő rostája” müködésének megakadályozása, az események lezárhatatlansága és feldolgozhatatlansága folytán, ha pedig egy csapásra eltünnek, akkor pedig információkat, emlékeket, tudást veszítünk, és e veszteségélmény sokkjával, támpontjaink elveszítésével kell szembenéznünk. Hogy e két véglet között lehet-e középút, megtanulhatunk-e bánni a technikai képekkel, ki tudunk-e alakítani egy új típusú képkultúrát, arra csak a jövő adhatja meg a választ. 


\section{Összegzés}

Dolgozatom egy aktuális jelenség felvázolását tüzte ki célul, egy olyan létmódét, amely egyfajta dokumentálási kényszerből ered, és az emberi életutat leképező, élethosszig táguló, redundáns elemeket felvonultató vizuális portfóliókban ölt testet. Ezen portfóliók alapegysége a kép, amely nem csupán önmagában létező alkotásként értelmezendő, hanem olyan nyitott struktúraként, amely tudást és ismereteket hordoz, kommunikál, és amelyre egy adott társadalom produktumaként is lehet tekinteni. A vizuális dokumentációképzés szempontjából kiemelten fontos a képek azon aspektusa, amely a megismerés lehetőségeiként és kulturális hordozóként teszi őket értelmezhetővé.

E porfóliók közege W. J. T. Mitchell két kifejezésével ragadható meg: a „képi fordulat” utáni „posztfotografikus időszak” tüneteiként tekinthetünk rájuk. Az elemeiket alkotó képek mindenekelőtt digitális fényképek, s mint ilyenek testetlenek, tiszta információként léteznek, ezáltal lezáratlanok és befejezetlenek.

A redundáns vizuális dokumentációképzés - mint a posztfotografikus éra szülöttének jellemző cselekedete - felé vezető út tüneteként regisztrálható a nyilvánosságnak szánt, „,profi” fotók (sajtófotók és reprezentációs célú fotók) és a privátfotók közötti határvonal elmosódása, amely összefügg azzal a folyamattal, melynek során a kép képtárgyi létéből tiszta információvá alakul. Ez tette lehetővé a képek gyors ütemü mediatizálódását, amelynek során a tárolási aktus helyett a publikálási aktus vált hangsúlyossá. A privátképek egyre kevésbé az utókornak, sokkal inkább a jelennek készülnek. Célközönségük kibővült az internet széles nyilvánosságával, céljuk az, hogy egy kiterjesztett jelenben - amely alatt az a néhány nap értendő, míg a közösségi médiatérben reakcióra tartanak számot - demonstráljanak egy létállapotot. E demonstráció pedig korlátok nélkül, redundánsan ismétlődik, mondhatni kényszeressé vált. Nem csupán képkészitésről beszélhetünk, hanem képkészitésről valahová, hiszen rendeltetésük, hogy a közösségi média valamely színterén nyilvánosságra találjanak - s ezáltal ellentétes pólusként egyfajta képfogyasztói magatartást is kialakítsanak. A képkészítés és képfogyasztás mértékének elképesztően dinamikus növekedése tovább gerjeszti azokat a változásokat, amelyeket Flusser már 1983-ban felfedezni vélt a kultúra és egyáltalán az emberi lét struktúrájában.

A lényegi módosulások egyike a kép emberre gyakorolt hatásában tapasztalható. Az ezredfordulóra ugyanis már nem a képtől a szemlélőre visszaható élmény áll e hatás középpontjában, hanem maga az empirikus tapasztalat helyére benyomuló kép. Az újmédia és a web 2.0 világa tökéletes terepnek bizonyul a képi meghatározottság mind szorosabbá 
válásához. Ettől elválaszthatatlan kísérőjelenség a vizuális infláció, a képek értékvesztésének folyamata, melynek oka nem csupán a mennyiségi növekedés, hanem a képeket elfedő megszokás. A posztfotografikus éra szülötte nem csupán a képektöl függ, hanem a mindig megújuló képektől. Bár a képek változnak és cserélődnek körülöttünk, e cserék ritkán hoznak valóban újszerü tartalmakat - így képi mivoltukban nem hívják fel magukra a figyelmet. Nem a képek, hanem a képek hiánya az, ami feltünővé válik. Egy-egy kép tehát már nem tud jelentős hatást kiváltani, az ember mégis ragaszkodik hozzájuk, kapaszkodik beléjük, a létrehozás aktusa szükségletként van jelen az életében. E szükségletet táplálhatja az freud-i drive, amely a szemlélésben és a szemlélve levésben mint gyönyörforrásban nyilvánul meg.

Szimptomatikus jelenség, hogy az adott időpillanatban megélhető látvány élvezete helyett az embert inkább annak rögzítése foglalkoztatja. Ennek egyik lehetséges oka, hogy a világot digitális kijelzőn át néző emberben nem tudatosul, hogy veszteséget szenved, vagy úgy gondolja, az élmény utólag, a képek megtekintése által bepótolható. De a jelenség magyarázata megragadható az önazonosság képlékenységében is: a kapaszkodóit veszített ember számára fontosabb az, hogy mások is érzékeljék, amit ö, mert szüksége van a visszajelzésekre, a reakciókra, amelyek segítenek neki annak meghatározásában, hogy miként viszonyuljon az érzékelt, látott dologhoz. Ez összefüggésben áll azzal a változással, hogy a természeti világ helyett egyre inkább a képek biztosítják a tapasztalatszerzési forrást. Ennek kapcsán felvetődik a kérdés, vajon beszélhetünk-e a valóság megkettőződéséről és a média teremtette másodlagos valóságról, pszeudo-valóságról? A dialogikus, interaktív médiumok hatóterében az empirikusan hozzáférhető világ és a média róla szóló leírásai között instabillá válik a különbség, hiszen e leírásokat a felhasználó maga alakítja. Kilép a passzív befogadó szerepéből, és valóságkonstrukciókban vesz részt. Az így konstruálódó valóság-elemek ugyan egy virtuális térben keletkeznek, de valós voltuk kétségbe vonása problémákba ütközik. Tehát nem feltétlenül kell két valóságról beszélnünk, inkább egy és ugyanazon valóság két síkjáról, melyek átjárhatók, vagy párhuzamosan megélhetők.

$\mathrm{Az}$ ember tehát dokumentáló lénnyé lett, sorsa egy vizuális portfólióként manifesztálódik. Ezen portfóliók létrehozása nem feltétlenül szándékos, elemei számos esetben inkább azzal a céllal keletkeznek, hogy megszólítsák a másik embert, információkat adjanak át számára, viszonyulásokat alakítsanak ki. A képekkel való kommunikáció egyre nagyobb teret hódít, ám kérdéses, hogy a képek valóban alkalmasak-e a szavak, vagy legalábbis a leírt szavak szerepének átvételére. Az önmagukban álló képek bizonyára nem, ám ha a képek együttesével és egymásutániságával is számolunk, illetve a vizuális dokumentációkban egyre nagyobb számban fellelhető mozgóképsorokat is tekintjük, akkor elképzelhető, hogy a képek nyelve a 
technikai fejlesztések segítségével egyre inkább alkalmassá válik a kommunikációra. Ezt azonban még számos tényező gátolja: az információáramlás sebessége miatt a vizuális kódok értelmezése nehéz, a jelek és jelrendszerek folyamatosan változnak, ki vannak szolgáltatva a kereskedelmi érdekeknek és a fogyasztói társadalom sodrásának. A szimbólumokat, jelképeket sokszor eredeti jelentésüktől megfosztva, dekorációs céllal használják.

A posztfotografikus éra szülötte a képekbe kapaszkodik, a képek által meghatározott életet él, a képekkel kommunikál, és sorsát a képek kormányozzák: ki van téve a vizuális média manipulatív megnyilvánulásainak és a média agresszorként való fellépésének. A befogadó figyelme irányítottá válik azáltal, hogy a mozgókép-szerkesztés megszabja látásának irányát és sebességét. A vizuális portfóliók elemeiben rejlő szándékos vagy szándéktalan manipuláció irányulhat kifelé, mások megtévesztésére, de akár a portfólió alanyára is azáltal, hogy hosszútávon befolyásolja emlékezetét és identitását.

Napjainkra a technikai képek váltak a leginkább preferált emlékhordozókká. Míg a belső emlékezet tárhelye véges, addig a külső, technikai emlékezet kapacitása gyakorlatilag végtelen - és e végtelenség arra készteti a kamerát állandóan a keze ügyében tartó embert, hogy élete minél több pillanatát megörökitse. Ezzel azonban az idő szelekciós szerepét és a felejtés lehetőségét negligálja: nehezebbé válik a történések feldolgozása, a tanulságok levonása, a lezárás és a továbblépés. Az emlékőrzés e módszerváltásával emlékeink tartalma, hangulata, minősége - és mindezzel együtt az önképünk, identitásunk konstruálásának folyamata is változásokon megy át. Máshová kerülnek a hangsúlyok, élményeink felidézése manipulálttá válhat. A bővülő tárhelykapacitások lehetővé teszik, hogy minden képet és képváltozatot megőrizzünk, pedig éppen az értékelés, a válogatás és az elrendezés lehetne az, ami elősegítheti, hogy a képek birtokosa el tudjon oldódni a jelentől, képes legyen viszonyulni múltjához, és elgondolni a jövőjét. A közösségi emlékezet pedig atomizálódik: egyre inkább individuális emlékek tömegéből tevődik össze, melyek olykor egymással ellentétes üzenetet hordoznak.

A posztfotografikus éra minden egyes szülöttje után egy-egy, elsősorban vizuális információkból álló digitális adathalmaz marad, melyek tág portfólióját képezik életútjuknak. Kérdéses, hogy az utókor számára ezek képviselhetnek-e akkora értéket, mint a megelőző korok képei napjaink embere számára - hiszen nem lesz könnyü képet alkotni egy olyan korról, amely képmilliárdok képezte töredékekből áll össze.

Ám nem feledkezhetünk meg arról, hogy a digitális adatokból összeálló vizuális portfóliók létezése értelemszerűen összefügg a digitális civilizációval, amely feltétele hozzáférhetőségüknek - így tartósságuk, fennmaradásuk megkérdőjelezhető. A vizuális portfóliók jövőbeli működésével kapcsolatosan tehát két lehetőség feltételezhető. Amennyiben 
megmaradnak és a tendencia folytatódik, akkor a múlt értelmezhetősége, lezárhatósága, a hibák korrigálhatósága válik majd kérdésessé. Ha azonban valamely, a digitális civilizációt ért csapás következtében elenyésznek, akkor kultúránk legjellegzetesebb megnyilvánulásai válnak a jövő számára láthatatlanná.

A fentiek alapján talán kijelenthető, hogy a mediatizált-digitális vizuális mezőkben megjelenő képek és az azokat szemlélő, illetve felhasználó ember közötti kapcsolat jól vizsgálható a vizuális portfóliók kontextusában. E portfóliók jellemzőinek áttekintése reményeim szerint felvillantott néhány olyan szempontot, melyek árnyalhatják a posztfotografikus éra szülöttének portréját. 


\section{Felhasznált irodalom}

- Adorno, Theodor W.: A kultúripar. In: Horkheimer, Max - Adorno, Theodor W.: A felvilágosodás dialektikája. Filozófiai töredékek. Gondolat - Atlantisz - Medvetánc, Budapest, 1990.

- Alpers, Svetlana: The Art of Describing: Dutch Art in the Seventeenth Century. The University of Chicago Press, 1983.

- Antik Sándor: Vizuális emlékezet és képi metaforák. Egyetemi Mühely Kiadó, Bolyai Társaság Kolozsvár, 2008.

- Antik Sándor: Vizuális megismerés és kommunikáció. Egyetemi Mühely Kiadó, Bolyai Társaság Kolozsvár, 2010.

- Arisztotelész: Metafizika (ford.: Halassy Nagy József), Lectum Kiadó, Szeged, 2002.

- Arnheim, Rudolf: A vizuális élmény. Az alkotó látás pszichológiája. Gondolat, Budapest, 1979.

- Assman, Jan: A kulturális emlékezet. Írás, emlékezés és politikai identitás a korai magaskultúrákban. Atlantisz, Budapest (é.n.)

- Aurelius, Augustinus: Vallomások. (ford.: Vass József) Szent István Társulat, Budapest, 1995.

- Bacsó Béla: A képtudomány margójára. In: Kép, látvány, szöveg. Studia Litteraria, 2013/1-2. LII. évfolyam

- Bacsó Béla: Az ikonikus differencia hermeneutikai jelentősége. In: Alföld, 66. évf. 11. szám, 2005.

- Bacsó Béla: Ön-Arc-Kép. Szempontok a portréhoz. Kijárat Kiadó, 2012.

- Baddeley, Alan: Az emberi emlékezet. Budapest, Osiris Kiadó, 2001.

- Bagdikian, Ben H.: Az új médiamonopólium. Fordította: Müller Ákos. Budapest, CompLex Kiadó, 2012.

- Bajomi-Lázár Péter: Média és társadalom. Antenna könyvek, PrintXBudavár Zrt. - Médiakutató Alapítvány, 2008.

- Bálványos Huba - Sánta László: A vizuális megismerés és a vizuális kommunikáció. Budapesti Tanítóképző Főiskola, 1996.

- Bán András: A vizuális antropológia felé. Typotex, Budapest, 2008.

- Bandura, A. \& Ross, D. \& Ross, Sh. A.: Film által közvetített agresszív modellek utánzása. In: Csepeli György (szerk.) Csoportlélektan. Budapest, Gondolat, 1981.

- Barbier, Frédéric - Bertho-Lavenir, Catherine: A média története. (Ford.: Balázs Péter) Osiris kiadó, 2004.

- Bárdos Artúr: A portré hanyatlása. In: Múvészet (Szerk.: Lyka Károly) XIII. évfolyam, 3. szám, 1914.

- Barta Judit: „Ha nem megy ellenük, csináld velük!” Médiakutató, 2007/ősz

- Barthes, Roland: A kép retorikája. In: Blaskó - Margitházi (szerk.): Vizuális kommunikáció. Szöveggyüjtemény. Typotex, Budapest, 2010.

- Barthes, Roland: Világoskamra. Európa Könyvkiadó, Budapest, 1985.

- Bätschmann, Oskar: Bevezetés a müvészettörténeti hermeneutikába. Corvina, Budapest, 1998. 
- Bätschmann, Oskar: Pygmalion als Betrachter. Die Rezeption von Plastik und Malerei in der zweiten Hälfte des 18. Jahrhunderts. In: Kemp, Wolfgang (szerk.): Der Betrachter ist im Bild. Reimer, Berlin, 1992.

- Baudrillard, Jean: A jelentés összeomlása a médiában. In: Angelusz Róbert, Tardos Róbert, Terestyéni Tamás (szerk.): Média, nyilvánosság, közvélemény. Gondolat Kiadó, Budapest, 2007.

- Baudrillard, Jean: A szimulákrum elsőbbsége. (Ford.: Gángó Gábor) In: Kiss Attila, Kovács Sándor, Odorics Ferenc (szerk.): Testes könyv I., Dekon könyvek, Ictus / JATE Irodalomelmélet Csoport, Szeged, 1996.

- Bellah, R.N., Madsen, R., Sullivan, W., Swidler, A., Tipton, S. M.: Habits of the Heart: Individualism and Commitment in American Life. University of California Press, Berkeley,1985.

- Belting, Hans: A müvészettörténet vége. Az elsö kiadás újragondolt változata - tíz év után. Atlantisz könyvkiadó, Budapest, 2007.

- Belting, Hans: Kép, médium, test: az ikonológia új megközelítésben. (Ford.: Matuska Ágnes) In: Apertúra, 2008. ősz http://uj.apertura.hu/2008/osz/belting/ (letöltés: 2017.09.25.)

- Benjamin, Walter: A müalkotás a technikai reprodukálhatóság korában (ford.: Kurucz Andrea, Mélyi József). http://aura.c3.hu/walter_benjamin.html (letöltés: 2018.02.02.)

- Berkeley, George: Értekezés az emberi ismeret alapelveiről. Gondolat, Budapest, 1985.

- Berlin, Isaiah: Négy esszé a szabadságról. (Ford.: Erős Ferenc és Berényi Gábor) Budapest, Európa Könyvkiadó, 1999.

- Berta Erzsébet: Szerkesztői elöszó. In: Kép, látvány, szöveg. Studia Litteraria, 2013/1-2. LII. évf.

- Biblia - Ószövetségi és Újszövetségi szentírás. Szent István Társulat, Az Apostoli Szentszék Könyvkiadója, Budapest, 2011.

- Boehm, Gottfried: A képi érzelem és az érzékszervek. (Ford. Poprády Judit) In: Bacsó Béla (szerk.): Kép, fenomén, valóság. Budapest, Kijárat Kiadó, 1997.

- Boehm, Gottfried: A képleirás. A kép és a nyelv határairól. (Ford.: Rózsahegyi Edit) In: Tomka Beáta (szerk.): Narratívák I. Képleírás - képi elbeszélés. Kijárat, Budapest, 1998.

- Boehm, Gottfried: Die Wiederkehr der Bilder. In: Boehm, Gottfried: Was ist ein Bild? München, Wilhelm Fink Verlag, 1994.

- Boehm, Gottfried: Látás. Hermeneutikai reflexiók. (Ford.: Kukla Krisztián.) A Nyíregyházi Főiskola adatbázisából. http://nyf.beckground.hu/incoming/filozofia2/3_mi_a_kep/boehm.rtf (letöltés: 2017.09.23.)

- Boehm, Gottfried: Mü és észlelés. A klasszikus modernség múzeumában. In: Gottfried Boehm: Paul Cézanne: Montagne Sainte-Victoire - Válogatott müvészeti írások. (Szerk.: Bacsó Béla) Kijárat Kiadó, 2005.

- Boehm, Gottfried: Vom Medium zum Bild. In: Yvonne Spielmann - Gundolf Winter (szerk.): Bild - Medium - Kunst. Wilhelm Fink Verlag, München, 1999.

- Bredekamp, Horst: Fordulópontok. Az iconic turn ismertetöjegyei és igényei. (ford.: Kékesi Zoltán) In: Nagy Edina (szerk.): A kép a médiamüvészet korában. L’Harmattan, 2006.

- Bredekamp, Horst: Mellözött hagyomány? A müvészettörténet mint képtudomány. Ford.: Wessely Anna, BUKSZ, 2003/3.

- Brown, Roger - Kulik, James: Flashbulb memory. In: Neisser, Ulric (szerk.): Memory observed. W.H. Freeman \& Company, 1982.

- Brugger, Walter: Filozófiai lexikon. Szent István Társulat, Budapest, 2005. 
- Bryson, Norman - Holly, Michael Ann - Moxey, Kieth: Visual Culture. Images and Interpretations. Wesleyan University Press, Hanover-London, 1994.

- Buzási Enikő (szerk.): Föúri ősgalériák, családi arcképek. Magyar Nemzeti Galéria, Budapest, 1988.

- Carey, James W.: Communication as Culture. Essays on Media and Society. New York \& London, Routledge, 1994.

- Clarke, A.M. \& Clarke A.D.B.: Thirty years od child psychology: A selective review. Journal of Child Psychology and Psychiatry. 1986/27.

- Cole, Michael \& Cole, Sheila R.: Fejlödéslélektan. Osiris Kiadó, Budapest, 1998.

- Crary, Jonathan: A megfigyelö módszerei. Osiris Kiadó, Budapest, 1999.

- Cusumano, Nicola: Mnémoszüné-Lészmoszüné: emlékezés és feledés, mitosz és történelem. (Ford.: Egyed Péter) In: Korunk, 1997. augusztus.

- Czuczor Gergely - Fogarasi János: A magyar nyelv szótára, 6. kötet, Athenaeum, Budapest, 1874.

- Csejtei Dezső: A minőségi élet esélyeiről. In: Csejtei Dezső: Irások Északról és Délszakról. Veszprémi Humán Tudományokért Intézet, Veszprém, 1999.

- Danto, Arthur C.: Hogyan semmizte ki a filozófia a müvészetet? Atlantisz kiadó, Budapest, 1997.

- Danto, Arthur C.: Történetek a müvészet végéröl. (1989) In: Perneczky Géza (szerk.): A müvészet vége? Európai füzetek, 1. szám. Új Világ Kiadó, 1995.

- Dikovskaya, Margaret: Interjú Martin Jay-jel. (2001.02.02.) In: Apertúra, 2013. tél. http://uj.apertura.hu/2013/tel/interju-martin-jay/

- Donald, Merlin: Az emberi gondolkodás eredete. (Ford.: Kárpáti Eszter). Budapest, Osiris Kiadó, 2001.

- Eco, Umberto: Az új középkor. Európa Kiadó, Budapest, 2008.

- Eliade, Mircea: Képek és jelképek. Európa Kiadó, Budapest, 1977.

- F. Orosz Sára: Vizuális kommunikáció, esztétika. Egyetemi jegyzet. Gödöllö, 2010.

- Fehér Katalin: A virtuális valóság elmélete és gyakorlata. In: Médiakutató, 2003. nyár

- Fiedler, Konrad: Schriften zur Kunst I. LXVI és XI.

- Film- és médiafogalmak kisszótára. Budapest, Korona Kiadó, 2002.

- Flusser, Vilém: A fotográfia filozófiája. Tartóshullám - Belvedere - ELTE BTK, Budapest, 1990.

- Földényi F. László: Képek előtt állni. Kalligram, Pozsony, 2010.

- Freud, Sigmund: Három értekezés a szexualitás elméletéröl. In: Freud, Sigmund: A szexuális élet pszichológiája. Budapest, Cserépfalvi, 1995.

- Frydman, Marcel: Televizió és agresszió. Budapest, Pont kiadó, 2004.

- Furbank, P.N.: Reflections on the Word „Image”. Secker\&Warburg, London, 1970.

- Gadamer, Hans Georg: Igazság és módszer. Egy filozófiai hermeneutika vázlata. (Fordította: Bonyhai Gábor) Gondolat Könyvkiadó, Budapest, 1984.

- Galán Anita: Az internetfüggőség kialakulása és prevalenciája. A hazai és nemzetközi kutatási eredmények összefoglalása. Metszetek, 2014/1. 
- Galassi, Peter: Before Photography: Painting and the Invention of Photography. Musem of Modern Art, New York, 1981.

- Gebner, George: A média rejtett üzenete. Budapest, Osiris Kiadó \& MTA-ELTE Kommunikációelméleti Kutatócsoport, 2000.

- Gehlen, Arnold: Kor-képek 1907-1914. A modern festészet szociológiája és esztétikája. Gondolat, Budapest, 1987.

- Gillmor, Dan: We the media. Grassroots Journalism by the People. O'Reilly, 2004.

- Gombrich, E.H.: A látható kép. In: Horányi Özséb (szerk.): Kommunikáció II., Budapest, Közgazdasági és Jogi kiadó, 1978.

- Gombrich, E.H.: Müvészet és illúzió, Gondolat Kiadó, Budapest, 1972.

- Gombrich, E.H.: The Mask and the Face: The Perception of Physiognomic Likeness in Life and Art. In: Art, Perception and Reality. The Johns Hopkins Univercity Press, Baltimore, 1972.

- Goodman, Nelson: Az újraalkotott valóságról és a képek hangjairól. In: Horányi Özséb (szek.): A sokarcú kép. Typotex, 2003.

- Greenwood, Dara: Three Reasons Why We Shouldn't Confuse Selfies with Vanity. Psychology Today, 2014. https://www.psychologytoday.com/blog/mirror-mirror/201409/three-reasons-whywe-shouldnt-confuse-selfies-vanity

- Gyenge Zoltán: Kép és mítosz II. A mitológia esztétikája. Typotex, Budapest, 2016.

- Hegel, G.W.F.: Esztétikai előadások I. Akadémiai Kiadó, Budapest,1980.

- Heidegger, Martin: A müalkotás eredete. (Fordította: Bacsó Béla) Európa Könyvkiadó, Budapest, 1988.

- Herbert, James D.: Visual Culture / Visual Studies. In: Nelson, Robert S. - Schiff, Richard (szerk.): Critical Terms for Art History. University of Chicago Press, Chicago, 2003.

- Hoppál - Jankovics - Nagy - Szemadám: Jelképtár. Helikon kiadó, 2010.

- Horányi Attila: Vizuális kultúra: dilemmák és feladatok. In: Magyar Építőmúvészet. http://meonline.hu/vizualis-kultura/vizualis-kultura-dilemmak-es-feladatok/ (letöltés: 2018.01.11.)

- Horányi Özséb - Szabó Levente: A kommunikáció ágenséröl. In: Horányi Özséb (szerk.): A kommunikáció mint participáció. AKI-Typotex, Budapest, 2006.

- Horányi Özséb (szerk.): A sokarcú kép. Válogatott tanulmányok a képek logikájáról. 2. módosított kiadás. Typotex, Budapest, 2003.

- Horányi Özséb: A vizuális kultúra szerepe a társadalmi fejlödésben és az életmód alakulásában. Az MTA Vizuális Kultúrakutató Bizottság számára készített vitaanyag. Budapest, Népmüvelési Intézet, 1980.

- Horányi Özséb: Adalékok a vizuális szöveg elméletéhez. In: Általános Nyelvészeti Tanulmányok XI. (szerk.: Telegdi Zsigmond - Szépe György) Budapest, Akadémiai Kiadó, 1975.

- Hornyik Sándor: A képi fordulat és a kritikai ikonológia. Balkon, 2007/11-12.

- Hornyik Sándor: Idegenek egy bünös városban. Müvészettörténetek és vizuális kultúrák. L'Harmattan - MTA Mủvészettörténeti Kutatóintézet, Budapest, 2011.

- Horváth Árpád: Camera obscura. A fényképezés és a film története. Táncsics Kiadó, Budapest, 1965.

- Imdahl, Max: Giotto. Arenafresken: Ikonographie, Ikonologie, Ikonik. Fink, München, 1988. 
- Imdahl, Max: Ikonika. Képek és szemlélésük. In: Bacsó Béla (szerk.): Kép, fenomén, valóság. Kijárat, 1997.

- Ingarden, Roman: Az irodalmi müalkotás. Gondolat, Budapest, 1977.

- Ivins, W.M. Jr.: A nyomtatott kép és a vizuális kommunikáció. Enciklopédia Kiadó, 2001.

- Jay, Martin: A modernitás látásrendszerei. In: Hal Foster (szerk.): Vision and Visuality. Bay Press, Seattle, 1988. (ford.: Végső Roland) A fordítás forrása: http://www.c3.hu/scripta/vulgo/2/12/jay.htm

- Jay, Martin: Downcast Eye: The Denigration of Vision in Twentieth-Century French Thought, Berkeley - Los Angeles - London, 1993.

- Kant, Immanuel: A tiszta ész kritikája, Atlantisz Könyvkiadó, 2009.

- Kepes György: A látás nyelve. Gondolat, Budapest, 1979.

- Kibédi Varga Áron: Vizuális argumentáció és vizuális narrativitás. In: Athenaeum, 1993. I./4. 169.

- Kjørup, Søren: George Innes és a Hastingsi csata, avagy hogyan tegyük képpel. In: Horányi Özséb (szerk.): A sokarcú kép. Typotex, Budapest, 2003.

- Kolta Magdolna - Tőry Klára: A fotográfia története. DFM, Budapest, 2007.

- Kroeber, A. L. - Kuckhohn, C.: Culture. A Critical Review of the Concepts and Definitions. Papers of Peabody Museum of Archeology and Ethnography, 1952.

- Krokovay Zsolt: Médiaetika. L'Harmattan, 2004.

- Kuhn, Thomas: A tudományos forradalmak szerkezete. Osiris, Budapest, 2002.

- Lacan, Jacques: The Four Fundamental Concepts of Psychoanalysis. London, Hogart Press, 1977.

- Laczkó Sándor (szerk.): Lábjegyzetek Platónhoz 15. Az emlékezet. Pro Philosophia Szegediensi Alapítvány, Magyar Filozófiai Társaság, Státus Kiadó, Szeged, 2017.

- Langer, Helmut: Visuelle Gestaltung - visuelle Inflation. In: Format, 17/2., 1985.

- Lázár Judit: A kommunikáció tudománya. Budapest, Balassi Kiadó, 2001.

- Lehmann Miklós: A digitális kép. http://lehmann.hu/lm/digitkep.pdf (Letöltés: 2018.01.22.)

- Lippmann, Walter: The World Outside and the Pictures in Our Heads. In: Public Opinion. New York, Harcourt, Brace and Co. 1922.

- Lippmann. Walter: A külvilág az elménkben. In: Angelusz - Tardos - Terestyéni (szerk.): Média, nyilvánosság, közvélemény. Gondolat Kiadó, Budapest, 2007.

- Luhmann, Niklas: A tömegmédia valósága. Gondolat - AKTI, Budapest, 2008.

- Manovich, Lev: Az újmédia nyelve: Mi az újmédia? In: Gerencsér Péter (szerk.): Új, média, müvészet. SzatírIKON könyvek, Universitas Szeged Kiadó, Szeged, 2008.

- Manovich, Lev: Jövö-kép. In: Gerencsér Péter (szerk.): Új, média, müvészet. SzatírIKON könyvek, Universitas Szeged Kiadó, 2008.

- Marcuse, Herbert: Az egydimenziós ember. Fordította: Józsa Péter. Kossuth Kiadó, 1990.

- Máté Zsuzsanna: A „,müvészet vége” dilemma müvészet/filozófiatörténeti diskurzusáról. In: Magyar Mủvészet. A Magyar Múvészeti Akadémia Lapja. 2018. VI. évfolyam 2. szám. 32-40. 
- Máté Zsuzsanna: Filozofikum és esztétikum kölcsönviszonyáról - kiemelten a madáchi életmüben. Madách Irodalmi Társaság, Szeged, 2018.

- McLuhan, Marshall: A Gutenberg-galaxis. Trezor, Budapest, 2001.

- McLuhan, Marshall: Understanding Media: The Extension of Man. McGraw-Hill, New York, 1964.

- Miklós Pál: Kép és kommunikáció. Budapest, MÚOSZ, 1980.

- Mirzoeff, Nicholas: Mi a vizuális kultúra? In: Ex-Symposion, 2000/32-33. szám. Ex-Symposion Alapítvány, Veszprém, 2000.

- Mitchell, W.J.T.: A képi fordulat. In: Szőnyi György Endre, Szauter Dóra: A képek politikája. W.J.T. Mitchell válogatott írásai. Jate Press, Szeged, 2012.

- Mitchell, W.J.T.: Mi a kép? In: Szőnyi György Endre, Szauter Dóra: A képek politikája. W.J.T. Mitchell válogatott írásai. Jate Press, Szeged, 2012.

- Mitchell, W.J.T.: Picture Theory, essays on Verbal and Visual Representation. Chicago: University of Chicago Press, 1994.

- Mitchell, W.J.T.: The Reconfigured Eye. Visual Truth in the Post-Photographic Era. MIT Press, Boston, 1992.

- Mitchell, W.J.T: Interdiszciplinaritás és vizuális kultúra. In: Magyar Építőmüvészet, http://meonline.hu/vizualis-kultura/interdiszciplinaritas-es-vizualis-kultura-kutatas/

- Mulvey, Laura: A vizuális élvezet és az elbeszélö film. Metropolis - Feminizmus és filmelmélet, 2006. http://metropolis.org.hu/?aid=118\&pid=16 (letöltés: 2018.03.19.)

- Mumford, Lewis: A gép mítosza. Budapest, Európa Könyvkiadó, 1986.

- Nacsinák Gergely András: Az emlékezés atlasza. Liget, 2015. szeptember 1. http://ligetmuhely.com/nacsinak-gergely-andras-az-emlekezes-atlasza/

- Nancy. J.L.: A portré tekintete. (Ford.: Seregi Tamás) Mücsarnok, 2010.

- Nyíri Kristóf: A gondolkodás képelmélete. In: Neumer Katalin (szerk.): Kép, beszéd, írás. Gondolat, 2003.

- Nyíri Kristóf: Kép és idő. Magyar Mercurius, Budapest, 2011.

- Nyíri Kristóf: Vizuális hazatérés - a neveléstudomány képi fordulata. In: Digitális pedagógia 2.0. Budapesti Müszaki és Gazdaságtudományi Egyetem/Typotex Kiadó. http://www.tankonyvtar.hu/hu/tartalom/tamop412A/2011-0023_DP/index.html

- Ortega Y Gasset, José: A tömegek lázadása. Fordította: Scholz László. Budapest, Nagyvilág, 2003.

- Panofsky, Erwin: A jelentés a vizuális müvészetekben. Gondolat, Budapest, 1984.

- Passuth Krisztina: A festészet mühelyében. Móra Kiadó, Budapest, 1964.

- Perneczky Géza: $A$ „,müvészet vége” - baleset vagy elmélet? In: Perneczky Géza (szerk.): A müvészet vége? Európai füzetek, 1. szám, Új Világ Kiadó, 1995.

- Platón: Az állam. Gondolat Kiadó, Budapest, 1988.

- Polányi Mihály: Személyes tudás I. Úton egy posztkritikai filozófiához. (Ford.: Papp Mária) Atlantisz, Budapest, 1994.

- Pratkanis, Anthony - Aronson, Elliot: A rábeszélögép. Élni és visszaélni a meggyözés mindennapos mesterségével. (ford.: Vámos Miklós) Ab Ovo, Budapest, 1992. 
- Pusztai Virág: A televiziós müsorgyártás és müsorszerkesztés gyakorlati alapjai. Szegedi Egyetemi Kiadó, Juhász Gyula Felsőoktatási Kiadó, Szeged, 2017.

- Ranschburg Jenö: Agresszivitás a képernyőn. In: Szávai Ilona (szerk.): Tévé elött - védtelenül? Tanulmányok a média hatásáról. Budapest, Pont Kiadó, 2010.

- Rényi András: Aby Warburg Rembrandtról: adalékok a performativ kép antropológiájához és a müvészettörténet recepcióesztétikai megújitásához.

http://www.renyiandras.hu/index.php?option=com_content\&view=article\&id=139:az-elfojtottpatosz-formulai\&catid $=60$ :mtoerteneszekrl\&Itemid $=159,2009$.

- Rivers, William L. - Mathews, Cleve: Médiaetika. (Ford.: Jánossy Ilona). Bagolyvár Kiadó, Budapest, 1993.

- Rónay Gabriella: A portré- és zsánerfényképezés fotótörténeti áttekintése. GDF Oktatástechnológiai Tanszék, 2005. http://mek.oszk.hu/09600/09694/html/index.html (letöltés: 2018.01.28.)

- Rorty, Richard (szerk.): The Linguistic Turn: Recent Essays in Philosophical Method. Chicago and London, The University of Chicago Press, 1967.

- Rose, Gillian: Pszichoanalizis: vizuális kultúra, vizuális élvezet, vizuális széthullás. In: Blaskó Margitházi: Vizuális kommunikáció szöveggyüjtemény. Typotex, 2010.

- Roser, Andreas: Léteznek-e autonóm képek? Észrevételek Otto Neurath és Ludwig Wittgenstein grafikus munkáihoz. In: Neumer Katalin (szerk.): Kép, beszéd, írás. Gondolat, Budapest, 2003.

- Rousseau, Jean-Jacques: A társadalmi szerződés. Fordította: Radványi Zsigmond. Phönix-Oravetz Kiadás, Budapest, 1947.

- Ryle, Gilbert: Dilemmas. Cambridge, 1954.

- S. Nagy Katalin: A látvány, amelyben élünk. Múegyetem Kiadó, Budapest, 1993.

- S. Nagy Katalin: Vizualitás, mint korunk gyermekbetegsége. http://www.oszk.hu/kiadvany/iras/14nk.html (letöltés: 2011.03.17.)

- Samuel, Raphael: Theatres of memory 1.: Past and Present in Contemporary Culture. London, Verso, 1994.

- Sandvig, Christian: Az internet szerkezeti problémái a kultúrpolitika nézöpontjából. In: Halácsy Péter, Vályi Gábor, Barry Wellman (szerk.): Hatalom a mobiltömegek kezében. Typotex, 2007.

- Schröter, Jens: Analóg/Digitális. Referencialitás és intermedialitás. Apertúra, 2012. tavasz http://apertura.hu/2012/tavasz/schroter-analog/digitalis (letöltés: 2018.04.13.)

- Schuster, Martin: Müvészetlélektan. Képi kommunikáció - Kreativitás - Esztétika. (Ford.: Balázs István) Panem Kiadó, 2005.

- Seidman, Gwendolyn: Are Selfies a Sign of Narcissism and Psychopathy? Psychology Today, 2015. https://www.psychologytoday.com/blog/close-encounters/201501/are-selfies-signnarcissism-and-psychopathy (letöltés: 2018.02.08.)

- Silverstone, Roger: Miért van szükség a média tanulmányozására? Akadémiai Kiadó, Budapest, 2008.

- Simmel, Georg: Rembrandt. Müvészetfilozófiai kísérlet. Corvina, 1986.

- Sontag, Susan: A fényképezésröl (Ford.: Nemes Anna) Európa Könyvkiadó, Debrecen, 1981.

- Sorokowska, Agnieszka: Selfies and personality: Who posts self-portrait photographs? https:/www.researchgate.net/publication/283514572_Selfies_and_personality_Who_posts_selfportrait_photographs (letöltés: 2018.01.31.) 
- Spengler, Oswald: A Nyugat alkonya. Első kötet. Fordította: Juhász Anikó és Csejtei Dezső. Noran Libro, Budapest, 2011.

- Stachó László - Molnár Bálint: Médiaerőszak: tények és mitoszok. In: Médiakutató, 2003. tél.

- Steiner, Rudolf: A szabadság filozófiája. Budapest, Genius Kiadó - Új Mani-fest Kiadó, 2005.

- Stiegler, Bernard.: Digitale Photographie als epistemologischer Bruch und historische Wende. In: Engell, L., Neitzel, B. (szerk.): Das Gesicht der Welt. Medien in der digitalen Kultur. München, 2004. 110 .

- Szabó Tibor: Az instabilitás kora. Belvedere Meridionale, Szeged, 2014.

- Szávai Ilona (szerk.): Tévé elött - védtelenül? Tanulmányok a média hatásáról. Budapest, Pont Kiadó, 2010.

- Szilágyi Gábor: A fotómüvészet története. A fényrajztól a holográfiáig. Képzőművészeti Alap Kiadóvállalata, Budapest, 1982.

- Szilágyi Gábor: Daguerre. Gondolat Kiadó, 1987.

- Szimán Oszkár: A szines fényképezés alapjai. Müszaki Könyvkiadó, Budapest, 1985.

- Szőnyi György Endre - Szauter Dóra (szerk.): A képek politikája. W.J.T. Mitchell válogatott írásai. JATE Press, Szeged, 2012.

- Szpilczyński, Stanisław: A látás kérdése Witelon (Vitellio) Peri Optices (1275) címü munkájában. Orvostörténeti Közlemények, 87-88, 1979.

- Tarnay László: Az új médiumok és a test prosztetikus dimenziói. In: Antalóczy Tímea (szerk.): Határtalan médiakultúra. Wolters Kluwer, Budapest, 2015.

- Tasnádi Róbert: Miröl szólnak a képek? In: Médiakutató, 2012 tél. http://www.mediakutato.hu/cikk/2012_04_tel/08_mirol_szolnak_a_kepek (Letöltés: 2018.01.11.)

- Tomsics Emőke: A történeti muzeológia felöl. Recenzió Bán András: A vizuális antropológia felé c. könyvéhez. In: Budapesti Könyvszemle, 2009. 333-339.

- Tóth Benedek: Médiumok és valóságaik. MTA Bölcsészettudományi Kutatóközpont, Budapest, 2014.

- Tóth Péter: A médiahatás-kutatás problémái: az agresszió és az erőszak rekonceptualizálása. In: Médiakutató, 2007. tél.

- Tylor, Edward Burnett: A kultúra tudománya. In: Maróti A. (szerk.): Forrásmunkák a kultúra elméletéböl, 1. szöveggyüjtemény. Budapest, Tankönyvkiadó, 1989

- Varga Emőke: Az illusztráció a teóriában, a kritikában, az oktatásban. L’Harmattan, 2012.

- Varga Gábor: Camera Obscura. In: Szellemkép müvészeti folyóirat, 2001/3.

- Vasari, Giorgio: Le vite de'piu ecellenti pittori, scultori ed architetti. Firenze, 1550. Magyarul megjelent: A legkiválóbb festók, szobrászok és épitészek élete. Vál.: Vayer Lajos. Ford.: Zsámboki Zoltán. Magyar Helikon, 1978.

- Vattimo, Gianni: A müvészet halála vagy hanyatlása. In: Perneczky Géza (szerk.): A müvészet vége? Európai füzetek, 1. szám, Új Világ Kiadó, 1995.

- Vekerdy Tamás: A képernyők varázsa. In: Szávai Ilona (szerk.): Tévé elött-védtelenül? Tanulmányok a média hatásáról. Pont Kiadó, Budapest, 2010.

- Vitányi Iván: A civilizáció és a kultúra paradigmái. In: Magyar Tudomány. 2002/6. 
- Warburg, Aby: Sandro Botticellis ,, Geburt der Venus” und „Frühling”: eine Untersuchung über die Vorstellungen von der Antike in der italienischen Frührenaissance. L. Voss, Hamburg, 1893.

- Wittgenstein, Ludwig: Filozófiai vizsgálódások. (ford.: Neumer Katalin) Atlantisz, 1992.

- Wollheim, Richard: Valamiként-látás, benne-látás és a képi reprezentáció. In: Bacsó Béla (szerk.): Kép, fenomén, valóság. Kijárat Kiadó, 1997. 229-241.

- Young, James E.: The Texture of Memory: Holocaust Memorials and Meaning. New Haven, CT, Yale University Press, 1993.

- Z. Karvalics László: Emlékezet és személyiség. In: Liget, 2012/7.

- Zámbó Kristóf: Gottfried Boehm és a képi differencia. In: Alföld, 66. évf. 11. szám, 2005. 